\title{
DE GODENSCHILDERING IN OVIDIUS' METAMORPHOSEN
}

J. C. ARENS 


\section{DE GODENSCHILDERING IN}

OVIDIUS METAMORPHOSEN 
PROMOTOR:

Prof. Dr. H. H. JANSSEN 


\section{DE GODENSCHILDERING IN OVIDIUS METAMORPHOSEN}

ACADEMISCH PROEFSCHRIFT TER VERKRIJGING VAN DEN GRAAD VAN DOCTOR IN DE LETTEREN EN WIJSBEGEERTE AAN DE R.R. UNIVERSITEIT TE NIJMEGEN, OP GEZAG VAN DEN RECTOR MAGNIFICUS Dr. J. D. M. CORNELISSEN, HOOGLEERAAR IN DE FACULTEIT DER LETTEREN EN WIJSBEGEERTE, VOLGENS BESLUIT VAN DEN SENAAT IN HET OPENBAAR TE VERDEDIGEN OP WOENSDAG 27 MAART 1946, DES NAMIDDAGS TE 3 UUR

DOOR

JOHANNES CORNELIS ARENS

GEBOREN TE HENGELO (O)

DRUKKERIJ GEBR. JANSSEN — NIJMEGEN - 1946 

Aan mïn Ouders

Aan de nagedachtenis

van Prof. Dr. Al. Sl̈̈pen S.J. 



\section{INHOUDSOPGAVE}

Inhoudsopgave , . . . . . . . . . . . . . . . . . . . . VII-VIII

Ljjst van geciteerde auteurs en hun werken . . . . . . . . . . . . IX-XII

INLEIDNNG . . . . . . . . . . . . . . . . . . . 1-34

§ 1. Overzicht der meeningen . . . . . . . . . . . . . . . 1-10

$\S$ 2. Ovidius poeta . . . . . . . . . . . . . . . . . . . . . . 10-18

§ 3. Ovidius voltooier van het alexandrinisme te Rome . . . . . . . 18-23

\$ 4. Alexandrijnsche godenschildering . . . . . . . . . . . . . 23-32

\$ 5. Verantwoording der methode . . . . . . . . . . . . . . 33-34

BESPREKING DER VERHALEN . . . . . . . . . . . . 35-166

Concilium Deorum (I 163-252) . . . . . . . . . . . . . . 35-38

Diluvium (I 262-342) . . . . . . . . . . . . . . . . . 38-39

Daphne (I 452-567) . . . . . . . . . . . . . . . . . . 39-42

Io $(\mathrm{I} 583-750)$. . . . . . . . . . . . . . . . . . . . . . . . . . . 42-46

Syrinx (I 698-712) . . . . . . . . . . . . . . . . . . 46-47

Phaethon (I 750-II 400) . . . . . . . . . . . . . . . . . 47-52

Callisto (II 409-530) . . . . . . . . . . . . . . . . . . . 52-57

Coronis (II 542-632) . . . . . . . . . . . . . . . . . . 57-60

Admetus et Battus (II 676-707) . . . . . . . . . . . . . . . . 60-61

Herse (II 708-832) . . . . . . . . . . . . . . . . . . . 61-64

Europa (II 833-875) . . . . . . . . . . . . . . . . . . 64-67

Actaeon (III 138-252) . . . . . . . . . . . . . . . . . 67-71

Semele (III 253-315) . . . . . . . . . . . . . . . . . . 72-74

Lis iocosa (III 316-338) . . . . . . . . . . . . . . . . . 74-75

Echo (III 362-369) . . . . . . . . . . . . . . . . . . 75

Mars et Venus (IV 171-189) . . . . . . . . . . . . . . . . . . 75-76

Leucothoé (IV 190-270) . . . . . . . . . . . . . . . . . 76-81

Salmacis (IV 285-388) . . . . . . . . . . . . . . . . . 81-83

Ino (IV 416-562) . . . . . . . . . . . . . . . . . . . . . . . . . . . 83-89

Medusa (IV 794-803) . . . . . . . . . . . . . . . . . . . 89-90

Musae (V 254-678) . . . . . . . . . . . . . . . . . . 90-94

Raptus Proserpinae (V 341-571) . . . . . . . . . . . . . . 94-100

Arethusa (V 572-641) . . . . . . . . . . . . . . . . . 100-102

Arachne (VI 1-145) . . . . . . . . . . . . . . . . . . 102-105

Niobe (VI 146-312) . . . . . . . . . . . . . . . . . . 105-107

Lycii coloni (VI 317-381) . . . . . . . . . . . . . . . . 107-110

Boreas (VI 682-713) . . . . . . . . . . . . . . . . . 110-111

Calydonius aper (VIII 273-281) . . . . . . . . . . . . . . 111-112

Convivium Acheloi (VIII 547-IX 97) . . . . . . . . . . . . 112-114

Echinades (VIII 577-589) . . . . . . . . . . . . . . . . 114 


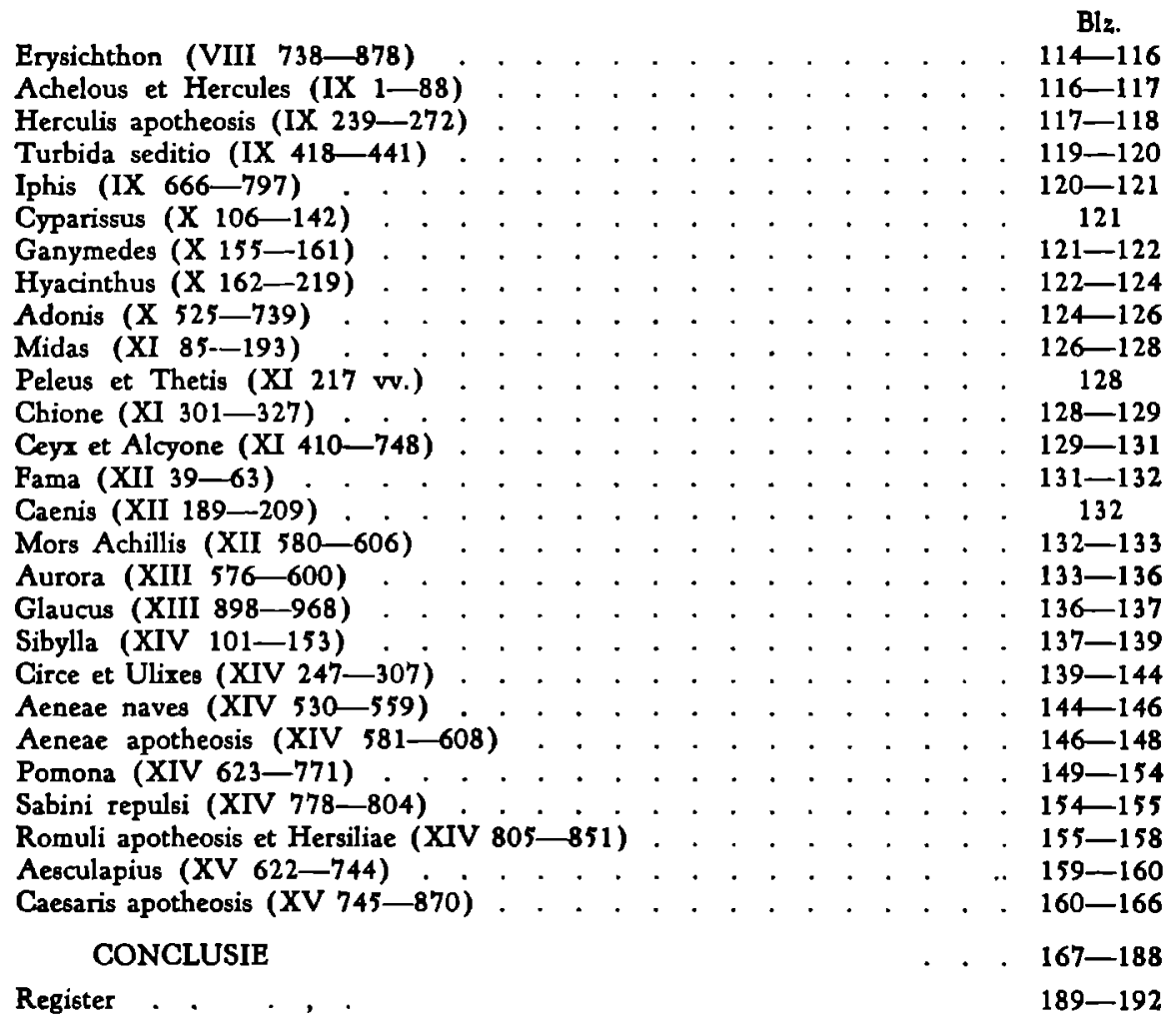




\section{LIJST VAN GECITEERDE AUTEURS EN HUN WERKEN}

Von Allmen O., Das Kind in der epischen Dichtung der Griechen, Diss. Bern 1923. Aly W., Geschichte der griechischen Literatur, Bielefeld und Leipzig 1925.

Barth ol om é H., Ovid und die antike Kunst, Diss. Mũnster 1935.

B a rwi ck K., Ovids Erzählung vom Raub der Proserpina und Nikanders Heteroiumena. Philologus 80 (N. P. 34), p. 454-466.

Beck R., De poematum Romanorum Graecas res tractantium colore Romano, Diss. Halis Saxonum 1933.

B e th e E. (G. L.), Griechische Literatur. Einleitung in die Altertumswissenschaft (Gercke und Norden), Leipzig 1924. I 3 p. 1-63.

Bethe E. (O. N.), Ovid und Nikander. Hermes XXXIX (1904), p. 1-14.

B ethe E. (G. D.), Die griechische Dichtung, Potsdam 1924.

B i e O., Die Musen in der antiken Kunst, Berlin 1887.

B i r Th., Kritik und Hermeneutik nebst Abriss des antiken Buchwesens, München 1913 (Handb. d. klass. Altertumswiss., hrsg. von Iwan Müller, I Bnd, 3e Aufl. 3. Abt.).

B o is s i e r G. (R. R.), La religion romaine d'Auguste aux Antonins, Tome I, Paris 1874 le ed. (geciteerd naar 7 de ed.).

Boissier G. (P. A.), Promenades archéologiques. Rome et Pompéi, Paris 1880 le ed. (geciteerd naar 14de ed.).

Boissier G. (E. O.), L'exil d'Ovide. L'opposition sous les Césars, Paris 1885, p. $107-159$.

Bra nd t P., P. O. N. De Arte Amatoria Libri Tres. Erklärt von P. Brandt, Leipzig 1902.

B r a n d t P., P. Ovidii Nasonis Amorum Libri Tres. Erklärt von P. Brandt, Leipzig 1911.

B r a u n J., Nonnos und Ovid, Greifswald 1935. (Greifswalder Beiträge Heft 11).

C a h e n E., Callimaque et son oeuvre poétique, Paris 1929.

Castiglioni L., Studi intorno alle fonti e alla composizione delle Metamorfosi di Ovidio, Pisa 1906.

C o u a $\mathrm{A}$., La poésie alexandrine sous les trois premiers Ptolémées (324-222 av. J.-C.), Paris 1882.

Von Christ W.Schmid W., Geschichte der griechischen Litteratur. II : Die nachklassische Periode der griechischen Litteratur. Erste Hälfte: Von 320 vor Christus bis 100 nach Christus. München 1920.

Cro is et A., Histoire de la littérature grecque. Tome Cinquième: Période alexandrine. Paris 1899.

De la n de J., Deux Allégories d'Ovide. Les Études Classiques IV (1935), p. 277-285 en $428-435$.

Dietze J., Komposition und Quellenbenutzung in Ovids Metamorphosen (Gelehrtenschule d. Johanneums, Bericht 1904/5), Hamburg 1905. 
Dietzler A., Die Akontios-Elegie des Kallimachos, Diss. Greifswald 1933.

E hwald R., Die Metamorphosen des P. O. N. Erklärt von M. Haupt, nach den Bearbeitungen von $O$. Korn und $H$. J. Müller in neunter Auflage herausgegeben von R. Ehwald. Erster Band: Buch I-VII, Berlin 1915. - Zweiter Band: Buch VIII-XV, erklärt von O. Korn, in vierter Auflage neu bearbeitet von R. Ehwald, Berlin 1916.

E itrem S., Observationes mythologicae maxime ad Ovidium spectantes. Philologus Bd. 58 (N. F. 12), 1899, p. 451-466.

Enk P. J., Het oorspronkelijk element in de Romeinsche letterkunde. Openbare les, Groningen 1922.

F a b ricius V., De diis fato Joveque in P. O. N. operibus quae supersunt, Lipsiae 1898.

Gerber A., Naturpersonification in Poesie und Kunst der Alten. Besonderer Abdruck aus dem dreizehnten Supplementbande der Jahrbücher f. class. Philologie, Leipzig 1883.

Grimal P., Les Métamorphoses d'Ovide et la peinture paysagiste à l'époque d'Auguste. Revue des Etudes Latines 16 (1938), p. 145-161.

Hardie W. R., Lectures on Classical Subjects, London 1903.

H a rtma n J. J., De Ovidio poeta commentatio, Lugduni Batavorum 1905.

H e inze R. (V. E. T.), Virgils epische Technik, 3. Aufl. Leipzig-Berlin 1915.

He in z e R., Ovids elegische Erzählung. Berichte der sãchsischen Akademie, Phil. Hist. Klasse, 1919 (71), Heft 7.

Herter H., Kallimachos und Homer. Ein Beitrag zur Interpretation des Hymnos auf Artemis. Xenia Bonnensia, Pestschrift zum 75. Bestehen des philolog. Vereins und Bonner Kreises, Bonn 1929, p. 50-105.

Herter H., (Pers.), Ovids Persephone-Erzählungen und ihre hellenistische Quellen. Rheinisches Museum N.F. (1941) p. 236-268.

He u m a n J., De epyllio alexandrino, Diss. Lipsiae, Koenigsee 1904.

High a m T. F., Ovid : Some Aspects of His Character and Aims. The Classical Review XLVIII (1934), p. 105-116.

$\mathrm{H}$ u ber G., Lebensschilderung und Kleinmalerei im hellenistischen Epos. Darstellung des menschlichen Lebens und der Affekte, Diss. Basel 1926.

Jackson C. N., The Latin Epyllion. Harvard Studies in Classical Philology XXIV (1913), p. 37-50.

K a p p I., Callimachi Hecalae fragmenta, Diss. Berolini 1915.

K a p p elm a $c$ h e $\mathrm{A}$., Die Literatur der Römer bis zur Karolingerzeit, Potsdam 1934.

Keh in ptzow F., De Quinti Smyrnaei fontibus ac mythopoeia, Diss. Kiliae 1891.

$\mathrm{K}$ ienzle H., Ovidius qua ratione compendium mythologicum ad metamorphoseis componendas adhibuerit, Diss. Basel 1903.

Kna a ck Gu., Quaestiones Phaethonteae (Philologische Untersuchungen hrsg, von A. Kiessling und U. v. Wilamowitz-Moellendorff, Heft 8), Berlin 1886.

K o ck Th., Comicorum Atticorum Fragmenta, Leipzig 1880-1888, 3 dln.

Körte A., Die hellenistische Dichtung, Leipzig 1925.

K roll W., Studien zum Verstāndnis der römischen Litteratur, Stuttgart 1924.

L a f a y e G. (Cat.), Catulle et ses modèles, Paris 1894.

L a f a y e G. (Met.), Les Métamorphoses d'Ovide et leurs modèles grees, Paris 1904.

L a m a r r e C., Histoire de la littérature latine au temps d'Auguste. Tome III, Paris 1907.

L e g r a nd Ph.E., La poésie alexandrine, Paris 1924.

L e o F., Die römische Literatur des Altertums. Kultur der Gegenwart, Teil I, Abhandlung VIII (Die griechische und lateinische Literatur), Berlin 1905, p. 313-373

$\mathrm{M}$ a h a f $f \mathrm{y}$ J. P., Greek Life and Thought, London 1887. 
Mä hly J., Geschichte der antiken Literatur, Erster Teil, Leipzig 1880.

Malte n L.. Ein alexandrinisches Gedicht vom Raube der Rore. Hermes 45 (1910), p. $506-553$.

Martini E. (O. B.), Ovid und seine Bedeutung für die rōmische Poesie. Epitumbion Swoboda, Reichenberg 1927, p. 165-194.

Martini E. (Einl.), Einleitung zu Ovid, Brünn enz. 1933 (Schriften der philosoph. Fakultät d. deutschen Universität in Prag, 12. Bnd.).

Mat z F., Die Naturpersonifikationen in der griechischen Kunst, Diss. Gōttingen 1913.

Miller F. J., Some Features of Ovid's Style. I : Personification of the Abstractions. The Classical Journal $11(1915 / 16)$, p. 516-534.

Moon e y G. W., Apollonius Rhodius Argonautica, edited with an introduction and a commentary, London, Dublin 1912.

M u r r a y G., Essays and Addresses, 2. ed. London 1922.

Ot is B., Ovid and the Augustans. Transactions and Proceedings of the American Philo logical Association LXIX (1938), p. 188-229.

Overbeck J., Die antiken Schriftquellen zur Geschichte der bildenden Künste bei den Griechen, Leipzig 1868.

O w e n S. G., P. O. N. Tristium Liber Secundus, edited with an introduction, translation and commentary, Oxford 1924.

$P_{a}$ u 1 , W i s o ow a, Real-Encyclopādie der class. Altertumswissenschaft. Neue Bearbeitung, Stuttgart 1894 vv.

Pf e iff er R., Kallimachosstudien. Untersuchungen zur Arsinoe und zu den Aitia des Kallimachos, München 1922.

Peters H., Symbola ad Ovidii artem epicam cognoscendam, Diss. Göttingen 1908.

Pichon R., Histoire de la littérature latine, Paris 1897 le ed. (geciteerd naar de 9de ed. 1924).

Platner S. B.Ashby Th., A Topographical Dictionary of Ancient Rome, Oxford, 1929.

Pohlenz M., Die Abfassungszeit von Ovids Metamorphosen. Hermes 48 (1913), p. $1-13$.

Pokrowsk y M., Neue Beitrāge zur Charakteristik Ovids. Philologus Suppl. Bnd. XI $(1907 / 10)$, p. $353-404$.

R a n d E. K., Ovid and His Influence, Boston 1925.

Reitzenstein R., Die Hochzeit des Peleus und der Thetis. Hermes XXXV (1900), p. $73-105$.

R ibbeck O., Geschichte der römischen Dichtung II : Augusteisches Zeitalter, Stuttgart 1889.

R i pe r t E., Ovide poète de l'amour, des dieux et de l'exil, Paris 1921.

Roh de A., De Ovidi arte epica capita duo, Diss. Berlin 1929.

Roh de E., Der griechische Roman und seine Vorläufer, Leipzig 1876 le ed. (geciteerd naar de 2 de ed. 1900).

Roscher W. H., Ausführliches Lexikon der griechischen und römischen Mythologie, Leipzig 1884 vv.

Rostag n i A., La letteratura di Roma repubblicana ed augustea, Bologna 1939 (Storia di Roma, Volume XXIV).

S chmidt R., Die Uebergangstechnik in den Metamorphosen des Ovid, Diss. Breslau, Zeulenroda 1938.

Sellar W. Y., The Roman Poets of the Augustan Age: Horace and the Elegiac Poets, Orford le ed. 1891 (geciteerd naar de editie van 1924).

Skuts ch F., Gallus und Vergil (Aus Vergils Frühezeit II), Leipzig 1906.

Sta ehel in H.. Die Religion des Kallimachos, Diss. Zürich 1934. 
Stemplinger E., Horaz im Urteil der Jahrhunderte (Das Erbe der Alten, Reihe 2 Bd. 5), Leipzig 1921.

S u semih1 F., Geschichte der griechischen Literatur in der Alexandrinerzeit, I Leipzig 1891.

Taylor L. R., The Divinity of the Roman Emperor, Middletown 1931.

Th om a n Th., Versuch über das Dichterische des Kallimachos, Diss. Zürich 1934.

T y rell R. Y., Latin Poetry, London 1900.

U s s a n i V., Storia della letteratura latina nelle età repubblicana e augustea, Milano 1929.

De la Ville de Mirmont H. (M. D.), Apollonius de Rhodes et Virgile. La mythologie et les dieux dans les Argonautiques et dans l'Énéide, Paris 1894.

Dela Ville de Mirm ont H. (J. O.). La jeunesse d'Ovide, Paris 1905.

Vollg ra ff Gu. (O. M.), De Ovidi Mythopoeia. Diss. Berolini 1901.

Vollg r a f W. (N. O.), Nikander und Ovid, Groningen 1909.

Werner H., Zum $\Lambda O Y K I O \Sigma$ H ONOE. Hermes 53 (1918), p. 225-261.

Wi che r s F., Quaestiones Ovidianae, Diss. Göttingae 1917.

Von Wilamowit z-Moellendorff U. (Hek.), Ueber die Hekale des Kallimachos, 1893. Kleine Schriften II, Hellenistische, spät-griechische und lateinische Poesie, Berlin 1941, p. $30-47$.

Von Wilamowitz-Moellendorff U. (H. D.), Hellenistische Dichtung in der Zeit des Kallimachos, 2 Bde, Berlin 1924.

W is s ow a G. (R. S.), Römische Sagen. Philologische Abhandlungen für Mart. Hertz, Berlin 1888, p. 156-168.

W is s ow a G. (R. K.), Religion und Kultus der Rōmer (Handb. d. klass. Altertumswissensch., hrsg. von Iwan Müller, V 4), München 1912 2e ed.

Zielinski Th., Erysichthon. Iresione tomus II (1936), Eus Supplementa, Vol. 8, p. 1 - 37.

Zingerle A., Ovidius und sein Verhältnis zu den Vorgängern und gleichzeitigen rōmischen Dichtern. Heft 1 : Ovid., Catull, Tibull, Properz. Innsbruck 1869. Heft 2 : Ovid., Ennius, Lucrez Vergil. Innsbruck 1871. Heft 3 : Ovid-Horaz. Stellenweiser. Innsbruck 1871 .

Zoelln er F., Analecta Ovidiana, Diss. Lipsiae 1892. 


\section{INLEIDING}

\section{§1. OVERZICHT DER MEENINGEN.}

De goden nemen in de Metamorphosen een zeer belangrijke plaats in, niet alleen omdat de gedaanteverwisselingen hun werk zijn (nam vos mutastis et illa), doch ook als medespelers in de bonte reeks van avonturen, waarop de dichter ons vergast. Doel van deze studie is, na te gaan, op welke wijze Ovidius in de Metamorphosen de goden behandelt en voor het voetlicht brengt. Over den indruk, dien zijn godenverhalen maken, en over 's dichters bedoelingen, loopen de meeningen der litteratuurhistorici sterk uiteen. Hoort men, aan den eenen kant, dat Ovidius een majesteitelijke schildering beoogd heeft en bereikt, aan den anderen kant heet het niet minder stellig, dat hij een burleske comedie heeft gegeven, waarin de goden op fijne wijze gehekeld worden. Daarom volge allereerst een overzicht der meeningen der litteratuurhistorici uit de vorige en uit deze eeuw, voorzoover wij hiervan kennis kregen en voorzoover de ongunst der tijden ons niet verhinderde hun werken te raadplegen.

Allereerst dan dient hier vermeld te worden $E_{r}$ win Rohde (1876), en wel omdat hij het verband gewezen heeft, waarin Ovidius' godenschildering geplaatst moet worden. Sprekend over de goden bij de alexandrijnsche dichters, merkt hij op, dat wij de eigenaardigheden dezer dichters heel in het bijzonder anntreffen in de Metamorphosen van Ovidius. Er bestaat dus een betrekking tusschen Ovidius en de Alexandrijnen. Rohde spreekt over die eigenaardige atmospheer, die om de goden hangt, die moeilijk met woorden te schilderen, doch voor een elk, die daartoe het zintuig heeft, onmiskenbaar is. De schrijver geeft hiermede de groote moeilijkheid aan, waarvoor men zich bij een studie als deze geplaatst ziet, namelijk het tastbaar maken van vaak uiterst subtiele nuances, ongrijpbaar welhaast, doch zeer wezenlijk; want het is de toon, die de muziek maakt. Rohde wijst dan vooral op het menschelijk karakter der alexandrijnsche goden, in het bijzonder in hun liefdesavonturen, waarin niet het resultaat eener verbintenis, doch het schilderen van den hartstocht hoofddoel is, zoodat er tusschen schilderingen van goddelijke en van menschelijke liefdesverhoudingen nauwelijks nog een verschil is. Hoogstens hebben de steeds wisselende neigingen der goden den fatalen bijsmaak der galante ondernemingen van een grand seigneur. Vooral Zeus en Apollo zijn de galante goden; doch alle goden zonder uitzondering zijn aan Venus onderworpen (p. 107/8).

Boissier, in 1874, merkt terloops op (R.R. p. 203/4), dat de meest 
eerbiedwaardige legendes onder Ovidius' handen tot enkel luchtige verhalen geworden zijn, die men glimlachend vertelt. Hij geeft enkele voorbeelden, waar men de goden onmogelijk serieus kan nemen. Enkele jaren later (1880, P. A. p. 375/8), meer eigenlijk over Ovidius' goden sprekend, blijkt hij zich R o h de's betoog ten nutte gemaakt te hebben, al geeft hij daarnevens blijk van zelfstandigheid. Thans wijst ook hij op het alexandrijnsch karakter van Ovidius, die er een gewoonte van maakt, de oude mythologie met alle middelen te verjongen; hieraan ontkomen de goden $z 00 \mathrm{~min}$ als de helden. $\mathrm{Zij}$ worden geteekend als menschen, en wel als menschen uit 's dichters eigen omgeving; de mythologie krijgt een modern voorkomen. Hier worden dus vermenschelijking en moderniseering in één adem genoemd. Verder wijst Boissier, meer dan Rohde, op het humoristisch en kluchtig moment in Ovidius' verhalen, waardoor de dichter volgens hem de producten der Alexandrijnen volkomen modificeert. In 1885 (E. O. p. 110/2) wees Boissier nogmaals op de moderniseering der oude verhalen en op de speelsche ironie, waarmede dit geschiedt.

Ook Ribbeck (1889, p. 299/311 passim), die ergens van alexandrijnsche detailschildering gewaagt, wijst op het moderne karakter der goden en op den humor in menig verhaal. Hij haalt verschillende gevallen aan, en bespreekt deze in even schalksche als verhelderende wendingen. $\mathrm{Zijn}$ invloed bespeurt men in tal van latere verhandelingen.

Waardevol, ofschoon hij niet rept over den alexandrijnschen inslag in Ovidius' -godenschildering, zijn de opmerkingen van Sella r (1891, p. 350/2), die 's dichters subtiliteit nog het meest recht laat wedervaren. Hoewel onvolledig, bevatten zijn opmerkingen een kern van waarheid. Hij wijst erop, dat Ovidius niet door geloof, doch door curiositeit gedreven wordt en dat hij, artiest, zich niet bezig houdt met de vraag, of de goden zijner verhalen de krachten zijn, welke uiteindelijk de wereld bestieren. Ovidius toont ons de goden van Homerus, doch ontdaan van alle majesteit en grandeur. In moreel opzicht staan zij beneden den standaard der menschheid veel verder dan Homerus' goden beneden dien zijner helden. De uitoefening van hun wraak wordt men hoofdzakelijk gewaar in het wreken van krenkingen hunner ijdelheid. Hiermede geeft Sella r de vervorming van het motief der ira deorum treffend weer; hem heeft dus ook de verregaande vermenschelijking der goden gefrappeerd. Over de moderniseering spreekt hij niet. Ovidius' goden zijn volgens hem de oude elementaire krachten, die door menschelijke instincten en anderszins verlevendigd zijn. Het is waarschijnlijk, dat de criticus hierbij gedacht heeft aan de merkwaardige gevallen, waarin gespeeld wordt met de dupliciteit van eponyme godheden, bijv. met Sol-god en Sol-zon. Op de vraag, of het Ovidius' bedoeling is satirisch te zijn, antwoordt Sellar even voorzichtig als verstandig, dat er waarschijnlijk geen opzettelijke, althans geen systematische satire is, omdat de goden voor den dichter louter voorwerpen van poëzie zijn. Overigens wil hij de mogelijkheid niet ontkennen, dat er in de schildering van een Juppiter en een Juno eenige ironie schuilt. De dichter voelt zich echter meer dan in de hemelsche regionen thuis bij de aardsche avonturen der jeugdige goden en bij de goden des velds.

Bij Sellar's opvattingen sluit zich Tyrrell aan (1900; p. 123). 
Dat de man van het klassieke verdict over Ovidius, $P_{1}$ ch on (1897), puntige opmerkingen maakt over het menschelijk en modern karakter der goden, is niet verwonderlyk (p. 422/4). Hy merkt op, dat de Olympus zeer Romeinsch is, en zeer galant. Ook wijst hy op het ver doorgevoerde spel met natuurkracht en eponyme godheid. Tenslotte wist hij erop, dat Ovidius door de paradox te forceeren, soms comische, groteske effecten weet te bereiken

Als A Croiset (1899) over de hymnen van Callimachus spreekt, weet hy niet beter te doen, dan te zeggen, dat er "de l'Ovide" is op elke bladzijde in deze hymnen, hetgeen hy dan nader aanduidt als "de l'esprit, sans aucun mélange de piété" (p. 218)

De la Ville de Mirmont (1905) noemt Ovidius den meest alexandrinnschen der Romeinsche dichters (J.O. p 38) Door een langdunge studie der alexandninsche dichters heeft zich het stempel van het Museum definitief en onutwischbaar in zun geest geprent, doch tusschen Ovidius' naturel en het alexandrinsme bestond reeds een "harmonie préétablie" (p 42) Ovidius' Muzen zijn nergens serieus, noch in Amores of Ars noch in Metamorphosen of Fastı De dichter is tot parodieeren geneigd. De koning der Olympiers wordt in de gedichten van Ovidius dikwills zonder het minste respect behandeld (p 262). Deze geleerde is hiervan zoozeer overtuigd, dat hij vermoedt, dat Ovidius' jeugdwerk, een Gigantomachia, waarin Augustus zou verheerlıkt worden onder den naam van Juppiter, om zijn parodische passages op last van hoogerhand niet tot voltooung is gekomen (p. 241/262).

Van het modern karakter van Ovidius' goden is ook F r Leo (1905) over. tungd, waar hij, betoogend, dat Ovidius' gedichten het spiegelbeeld zijn van de wufte wereld uit Augustus' tyjd, onder meer op de goden en helden wijst in Metamorphosen en Fast1. De plechtige waardigheid, anders van zulke onderwerpen onafscheidelijk, is voor den vroolyken glans eener feestzaal geweken, waann ook de goden het liefst jong, schoon en verliefd zijn (p. 353).

In tegenstelling tot genoemde critic, die Ovidius' dartelheid onbevangen accepteeren, zonder eeng gewetensbezwaar, gevoelt La faye (Met, 1904) behoefte om Ovidius' moraliteit en orthodoxıe te redden. Merkwaardige oprechtheid in het constateeren van Ovidiaansche stoutigheden gaat bij hem hand in hand met een advocatische welbespraaktheid in het verdedigen van zijn lastigen client. In zijn bespreking van ideeen en personnages in de Metamorphosen ( $p 96$ vv.) noemt hij vier punten, galanterie, eruditie, vermenschelijking en moderniseenng, allen van alexandrijnsche herkomst, en die in hun vermenging aan de verhalen een bijzonderen smaak geven De tendens om van goden en helden vooral het leven van allen dag te schilderen maakt, dat de grootheid der personnages een pikant contrast oplevert met het realisme der schildenng Hierin ligt de voornaamste reden, waarom Ovidius' goden en helden tot oneerbiedigherd prikkelen, want doordat de bovennatuurlyke wereld te zeer die der menschen nadert, verdwijnt het respect, dat door afstand vergroot wordt (p 106) De goden zijn niet slechts amoureus, doch ook galant en zeer galant ( $p$ 100) De snelle opeenvolging hunner galante avonturen wekt een ongelukkigen indruk; zij schijnen zich louter met hun genoegens bezig te houden, zoodat de Meta- 
morphosen niet zoozeer een epos zijn alswel een gedicht, waarvan de hoofdpersonen hun waardigheid elk oogenblik compromitteeren. Dat Ovidius dit zeer wel wist, bewijst een treffende formuleering, die hij er zelf aan gaf (p. 102). Doordat de dichter, die hun deugden niet verheft, doch die hen toch ook toont in het straffen van de misdaad, hen wel met autoriteit bekleedt en hen als de autoriteit zelve behandelt, wordt weliswaar het geheel niet stichtelijker, maar deze afdwalingen laten den lezer met nog meer genoegen terugkeeren tot het schouwspel hunner beminnelijke ondeugden (p. 103). Zij zijn niet slechts menschen, doch ook Romeinen uit Augustus' tijd (p. 110). Met een duidelijke reminiscentie aan Couat (p. 306) zegt onze criticus, dat Ovidius' goden afbeeldingen zijn der Caesaren, zooals die der alexandrijnsche dichters afbeeldingen zijn der Ptolemaeën. Hun hof is galant, en onophoudelijk in beroering door intrigues, waarin liefde en eerzucht dooreenspelen; zelf zeer gesteld op hun genoegens, brengen zij hun, die hun autoriteit trotseeren of hun hartstochten dwarsboomen, geduchte slagen toe; majesteitschennis is de grootste misdaad (p. 112). Dat allegorische figuren bij Ovidius talrijker en uitvoeriger geteekend voorkomen dan bij eenigen ons behouden voorganger, verklaart $L$ a $f$ a ye hiermede, dat deze figuren, vaag omlijnd als zij zijn en een soort rudimentaire legende, wegens de ruimte, die zij laten voor vrijheden, beschrijvingen en esprit, gemakkelijke ficties waren voor dichters, die in de gangbare legenden slechts matig geloofden (p. 100). Hoe echter Ovidius' godenschildering te beoordeelen? Ten stelligste ontkent $\mathbf{L}$ a $f$ a ye, dat Ovidius een ironisch werk heeft willen schrijven (p. 96), ook al geeft hij toe, dat niemand beter dan Ovidius aan Lucianus den weg bereid heeft (p. 106). Ovidius zelf acht hij voor het ontbreken van de goddelijke majesteit slechts ten deele verantwoordelijk (p. 239), omdat hij drie eeuwen poëzie resumeert, waarvan hij de gewoonten heeft overgenomen zonder nochtans het gevaar ervan ook maar te vermoeden (p. 107); zoodoende betaalt Ovidius het gelag voor een gansche familie van dichters, wier werken voor ons verloren zijn gegaan en onder wie hij zich vrijwillig geclasseerd heeft. Het alexandrinisme, waarmede hij van nature nauwe verwantschap had, heeft hij al te zeer in zich opgenomen; voor de erotische verhalen komt daar nog bij zijn erotisch verleden als auteur (p. 239). Zoozeer heeft hij het alexandrinisme in zich opgenomen, dat hij, ook in verhalen, die niet op alexandrijnsche dichters teruggaan, de alexandrijnsche principes toepast en bijv. een Homerus verjongt door dezen aan de gewoonten der alexandrijnsche poëzie te conformeeren (p. 132); ook in de nationale legendes opereert hij sterk met alexandrijnsche middelen (p. 230). Zijn gebreken zijn minder het resultaat van boozen opzet of van een verderflijke nieuwigheid dan het erfgoed van de drie laatste eeuwen van Hellenisme (p. 239). Op grond hiervan noemt $L$ a f a y e hierbij de opmerking van Boissier (E.O. p. 141) ignoreerend (dien hij overigens goed blijkt te kennen), dat zekere lieden er nimmer in zullen slagen zich voor naief te laten doorgaan - Ovidius het onschuldig slachtoffer van alexandrijnsche praktijken. Zoo eindigt dit pleidooi, dat menige waardevolle opmerking bevat. Aan het begin van zijn betoog wijst de schrijver er met veel emphase op, dat mythologie en religie scherp onderscheiden moeten worden, dat 
voor de ouden de mythen de poëzie zelve waren. Men vraagt zich af, of deze mythen voor den criticus meer dan voor den antieken dichter met de strenge religie verbonden zijn. $L$ a f a y e erkent, dat wij moeite hebben onzen ernst te bewaren tegenover die goden, welke enkel met hun genoegens bezig schijnen te zijn (p. 102). Waartoe de moeite voor den ernst der religie, als ons slechts het genoegen der poëzie geboden wordt?

L a ma r re (1907; p. 188/91) wijst vooral op de moderniseering der goden; in de voorbeelden, die hij geeft, bespeurt men vooral den invloed van B o is s i e r. Hij betoogt verder, dat in sommige passages de familiariteit van taal en gedrag der goden een comisch effect sorteert, bijna grotesk, gelijkend op parodie. Hij wijt dit aan een volslagen gebrek aan smaak en tact bij Ovidius. Van alexandrijnschen invloed in genoemde merkwaardigheden rept hij niet.

Voornamelijk omdat hij $\mathrm{He}$ in ze voor diens theorie over de godenschildering verschillende argumenten geleverd heeft, dient vervolgens Peters (1908) genoemd te worden. Volgens dezen vertoonen de goden geenszins de natuur van goden, doch het karakter van rijke, aanzienlijke Romeinen (p. 79v.); in zijn voorbeelden bespeurt men den invloed van $R$ ibbeck, al zwijgt Peters nagenoeg geheel over den humor in Ovidius' godenschildering. Naar aanleiding van Iris' kleed spreekt hij ook over de dupliciteit der goden, die namelijk natuurverschijnsel en persoonlijke gestalte tegelijk zijn (p. 37). Om verschillende redenen nemen de godenverhalen een aparte plaats in de Metamorphosen in: wij vinden hierin geen gemoedsbeschrijvingen (p. 70), er wordt meer actie dan affect geschilderd (p. 73), bij de goden is er nimmer strijd tegen de liefde (p. 74), hun liefdes ontstaan anders dan bij de menschen (p. 74), in geen der godenverhalen treffen wij een lang soliloquium (p. 95v.). Hierin bespeurt P e t e r s den invloed van Ovidius' voorbeelden : waar eerst de Alexandrijnen de goden als gewone menschen schilderen, komen genoemde merkwaardigheden op rekening van Ovidius' oude, dat wil zeggen prae-alexandrijnsche modellen. Wel met het oog op de oude godenverhalen betoogt Peters, dat Ovidius wel in vele, doch niet in alle opzichten tot de alexandrijnsche dichters gerekend dient te worden (p. 92). P eters constateert voorts, dat meer dan één verhaal opent met een hemelsche scène (pp. 37, 46, 54,61); waar dit enkel bij het verhaal eener godenliefde geschiedt, geschiedt dit, omdat er een godenliefde verteld gaat worden ( $p .75$ ) ; hieraan knoopt de criticus geen verdere beschouwing vast.

Vermelding verdient ook $\mathrm{Eh}$ wald $(1915 / 16)$, die in zijn commentaar een open oog toont te hebben voor de vermenschelijking en moderniseering der goden en eenige malen met instemming $R$ ibbeck anhaalt. In den loop van de bespreking der verhalen zal hij herhaaldelijk geciteerd worden.

Een beslissend keerpunt in de waardeering van Ovidius' godenschildering (althans voor de Duitsche en aanverwante wetenschap) vormt $\mathrm{Heinze}$ 's betoog over den elegischen stijl, waarvan zijn theorie over de godenverhalen een belangrijk onderdeel is $(1919 ;$ p. $10 / 9 ; 102 / 6)$. De Metamorphosen zijn exemplarisch voor den epischen, de Fasti voor den elegischen stijl. Een der hoofdpunten van verschil tusschen de epische en de elegische vertelling zou hierin bestaan, dat in de epische vertelling de majesteit der goden zorgvuldig 
gecultiveerd wordt, in de elegische daarentegen hun vermenschelijking. Dat Ovidius er zooveel doenlijk naar streeft de goden met majesteit te bekleeden, is enkel een kwestie van stijl, niet van geloof. Hij is erop bedacht de goden zooveel mogelijk te sublimeeren, en wel, positief, door een weloverwogen gebruik van het motief der ira deorum en door op andere wijzen hun majesteit te bevorderen, negatief, door onwaardige trekken naar mogelijkheid weg te werken. Dit laatste geldt vooral van de liefdesverhalen, die een netelige, doch onvermijdelijke stof vormden. Van burleske is geen sprake. Ovidius uit geen twijfel omtrent het wonderbaarlijke, hij beschrijft van een god het verliefd worden niet, de goden lijden in hun liefdes geen fiasco's, het aanstootelijke van goden in dierengestalte wordt tot een minimum gereduceerd. Niet overal weliswar kon deze sublimatie slagen, met name niet in de liefdesverhalen; doch, waar een lichte daling van het niveau der majesteit noodzakelijk was, daar geschiedde dit zeer tegen den wil des dichters.

Ofschoon deze paragraaf vooral bedoeld is als een registratie der meeningen, lijkt het ons gewenscht, wegens den grooten en fatalen invloed, dien H e in z e's uiteenzetting heeft uitgeoefend op latere studies, dat eenige harde waarheden omtrent diens betoog onomwonden worden uitgesproken. H e in z e zet niet de theorieën naar de feiten, doch de feiten naar de theorieën. Hij proclameert de uitzonderingen als den regel, zooals later zal worden aangetoond. Weerbarstige feiten verdraait hij deels, deels laat hij ze onvermeld, en, zoo moeten wij er tot ons leedwezen aan toevoegen, het heeft er daarbij allen schijn van, dat hij dit met opzet doet. Ergens verwijst hij, in voorzichtige termen, naar een criticus, van wien hij weet, dat deze incompetent is (zie onder „Lycii coloni”). Waar het hem dienstig is, weet hij zich uitspraken van voorgangers te herinneren. Hij citeert bijv., naar aanleiding van een godenraad in de vermenschelijkende Fasti, (p. 69 n. 2) R ibbeck's opmerking ,wie eine Parodie". Doch in andere gevallen, waar hij zonder eenigen twijfel de uitspraken zijner voorgangers kent, uitspraken echter, die indruischen tegen zijn favoriete theorie, zwijgt hij in alle talen (zie bijv. onder "Io" en „Herse"). Het minste, dat men van zijn betoog kan zeggen, is, dat het moeilijk zou vallen aan $\mathrm{He}$ in ze's wetenschappelijke goede trouw te gelooven, indien men niet uit eigen ervaring wist, hoe licht men door een vondst verblind raakt.

Nochtans, zoo groot gezag genoot $\mathrm{He}$ in z e, vooral bij de Duitsche philologen, dat deze theorie over Ovidius' godenschildering algemeen aanvaard werd en slechts allengs bezwaren met grootere vrijmoedigheid geopperd werden. De eerste reactie, voor zoover ons bekend, op $\mathrm{He}$ in ze's godentheorie kwam van Kroll (1924; p. $215 \mathrm{v}$.), die, schoon vurig Heinziaan, diens voorstelling van zaken, in apologiseerende en zeer euphemistische termen evenwel, behoedzaam retoucheert. De epische verhevenheid, zoo merkt hij op, is ,manchmal und kaum merklich" wat minder, en dit geldt ook voor de schildering der goden, die ,nicht ganz so erhaben" zijn als in het groote epos. Dit wijt hij aan de humoristische plaatsen in Homerus, doch hoofdzakelijk aan het feit, dat Ovidius aan zijn temperament den vrijen teugel liet. $\mathrm{Na}$ als voorbeelden enkele passages uit "Callisto", „Lis iocosa" en „Scylla” gegeven te hebben, haast K r o 11 zich evenwel 
geruststellend te verklaren, dat deze zaken "ganz diskret" behandeld zijn, en niet zoozeer veranderingen opleveren als wel modificaties.

Overtuigd aanhanger van $\mathrm{He}$ inze, ontveinst zich ook Martini (1927; O. B. p. 187 n. 1) niet, dat de rekening niet zoo glad opgaat, als $\mathrm{H}$ e in ze het gelieft voor te stellen. Met een beroep op $\mathrm{Kroll}$ constateert hij in zake de godenschildering, dat Ovidius hen "gelegentlich etwas" minder verheven schildert, doch dat dit van weinig belang is en door de natuur van de betreffende stof gegeven.

Ook A If red Rohde, in zijn waardevolle dissertatie (1929; p. 15. n. 17), is Heinziaan, doch reeds vrijer in zijn opmerkingen. Hij vreest, dat $\mathrm{He}$ in ze overdreven heeft, omdat Ovidius ook wel dingen invoegt, die zeer strijdig zijn met de goddelijke verhevenheid. Hij draagt menschelijke hebbelijkheden op de goden over, in aansluiting aan Homerus, dien op hun beurt de Alexandrijnen nagevolgd hadden. (Men ziet, dat deze stem weer van vermenschelijking durft spreken en, zij het ook indirect, vạn overeenkomsten met de alexandrijnsche dichters). In het genoemde volgt Ovidius zijn voorgangers; wat hem persoonlijk eigen is, is het dartele spel, het pointeeren, het spel met de dubbele beteekenis van sommige godennamen. Deels bedacht op verhevenheid (traditioneel en episch element), deels speelsch (eigen element), is Ovidius dus, volgens $R$ o h de, in strijd met zichzelf, wat hieruit voortvloeit, dat aan zijn goden geen religiositeit ten grondslag ligt.

Zes jaren na zijn eerste reactie, sprekend over Ovidius als de voltooier van het alexandrinisme te Rome, merkt Martini (1933; Einl. p. 77) op, $\mathrm{H}$ e in ze's theorie in dezen vergetend of verwerpend, - dat onze dichter met de Alexandrijnen onder meer gemeen heeft de moderniseering van het verleden en die lichtelijk ironische behandeling van goden- en heldensage, welke voor Callimachus zoo karakteristiek is.

K a p pelma che r vervolgens (1934; p. 294) treedt ook in het voetspoor van $\mathrm{He}$ inze, doch is tevens op de hoogte van de laatste ontwikkelingen door diens modificatoren. De majesteit der goden is „vielfach gemildert", en, als bij Homerus, ontbreken de menschelijke zwakheden niet.

B eck (1933 ; p. 86) wijst op de verregaande vermenschelijking en moderniseering der goden door Ovidius. In de voorbeelden, die hij p. 13 geeft, bespeurt men den invloed van R ib beck. Waarschijnlijk kent $B$ eck de theorie van $\mathrm{He}$ inze niet, omdat hij noch voor noch tegen diens opvattingen stelling neemt.

Een onverdeeld Heinziaan (wijl hij diens modificatoren niet kende?) betuigt zich daarentegen Bartholomé (1935; p. 83/5). De moderniseeringen verklaart hij aldus, dat Ovidius, om zijn lezers plastische, levende beelden voor oogen te tooveren, de mythologische gestalten in zijn eigen tijd overbracht, waarbij hij de vele, daaruit voortvloeiende anachronismen als onvermijdelijk accepteerde (p. 86).

Volgens $\mathrm{Schmidt}(1938 ;$ p. 48) is Ovidius er zich in zijn godenschildering weliswaar van bewust, wat hij aan het episch karakter der Metamorphosen verschuldigd is (Heinze), maar wijkt hij toch juist in de hemelsche scènes 
sterk af van de verhevenheid van het epos en laat zijn temperament den vrijen teugel; voor zijn gedrag zijn wellicht de humoristische plaatsen in Homerus verantwoordelijk. Schmidt verwijst hierbij naar $\mathrm{Kroll}$. Merkwaardig is, dat hij niet diens omzichtige termen gebruikt, doch een onomwonden "stark", wellicht onder invloed van de opmerkingen van $A$. Rohde. Het gaat er in den godenraad menigmaal zeer bewogen toe. Elders (p. 103) merkt S ch midt op, dat sommige hemelsche scènes ,mit einem leise lächelnden Humor" behan. deld worden.

Ook daar, waar buiten Duitschland echo's van Heinze's betoog vernomen worden (voor zoover ons bekend), stemmen de geleerden met hem in. Zoo sluit zich in ons land $\mathrm{E} n \mathrm{k}$ in 1922 (p. 16v.) aan bij deze nouveauté, en in Italië vermeldt U ss a n i uitdrukkelijk (1929; p. 394), dat de hartstocht bij de goden niet beschreven wordt noch de groei der verliefdheid, dat travestie in het algemeen is vermeden.

Reacties op $\mathrm{He}$ in ze's theorie uit andere landen heb ik niet gevonden dan in een studie van den Amerikaan $\mathrm{O}$ tis (zie beneden). Men heeft er geen kennis van genomen, of men heeft ze geignoreerd. Van de critici buiten de invloedssfeer van Heinze moet allereerst de Franschman Ripert (1921), vermeld worden, die, geen vakgeleerde, over Ovidius een charmant en verdienstelijk boek schreef. Bij hem is invloed van $L$ a f a y e merkbaar. Ovidius, zoo betoogt hij, imiteert zeer zeker de Alexandrijnen, doch wij mogen daarbij niet vergeten, dat onze dichter zich de mythologie geheel eigen heeft gemaakt, en dat de werkelijke en imaginaire wereld in zijn geest dooreengeweven zijn (p. 104). In de godenverhalen zijn wel "quelques sourires" (p. 108), maar Ovidius bedoelt niet te spotten; hij is geen Lucianus.

Een Engelsche stem is die van O wen $(1924 ;$ p. 81), die spreekt van de frivoliteit, waarmede Ovidius de mythologische tradities in de Metamorphosen boekstaafde.

De opvatting van den Amerikaan $\mathrm{R}$ and (1925) is, dat Ovidius een Divina Comoedia geschreven heeft. Noch over alexandrinisme noch over het spel met de dupliciteit van eponyme godheden rept hij, wel spreekt hij in exuberante termen over de moderniteit der goden (p. 59). Op de amoureusiteit der ,jovial deities" (p. 60) legt hij veel nadruk. Nooit was Aristoteles' uitspraak beter gerechtvaardigd, dat de personen der comedie slechter zijn dan die uit het leven van allen dag (p. 61). Protagonist is de licht ontvlambare Juppiter, die steeds door Nemesis in de persoon van Juno gedwarsboomd wordt. Hij wordt waardig gesecondeerd door Phoebus en Mercurius, terwijl ook de overige goden zich niet onbetuigd laten. $\mathrm{Zijn}$ godenburleskes (p. 73) vormen in de eerste vijf boeken een ,irreverent comedy"; het weefsel van Arachne is de groote finale van Ovidius' Goddelijke Comedie (p. 63). Ovidius verdient een prijs voor het ridiculiseeren van een versleten theologie, wat hij doet met een fijne puntigheid, waarbij Lucianus' vertoogen primitief schijnen (p. 63). De teedere dichter van Juppiter's liefdes zou zelfs voor de Metamorphosen alleen reeds hebben kunnen verbannen worden (p. 92). Met Ovidius' geloof hebben deze burlesques evenwel niets uit te staan. Dat Ovidius irreligieus zou zijn, zooals Sella r beweert, 
bestrijdt $R$ and met veel energie. Slechts als wij zijn verhalen lezen ,with Mediaeval freedom in mind" (p. 122), begrijpend, dat van het sublieme naar het ridicule slechts één pas is, kunnen wij volgens $R$ a n $d$ deze burlesques naar waarde apprecieeren.

Voor Delande (1935; p. 280/1) staat het vast, dat Ovidius er zich even weinig om bekreunt een "oeuvre de piété" te maken als voor zedenmeester te spelen. De goden zijn hartstochtelijker dan de menschen en leven even veel op de aarde als op den Olympus. Met de personificaties bedrijft Ovidius midden in het land der legende een spel van verbeelding, dat nauwelijks den naam van allegorie verdient.

Tenslotte dient de opvatting van Ot is (1938) vermeld te worden. Deze is, mijns wetens, de eenige geleerde uit de Engelsch sprekende wereld, die ervan blijk geeft $\mathrm{Heinze}$ 's theorie te kennen alsmede de retouches door diens modificatoren. Hij verwerkt hun opvattingen echter in een zelfstandig betoog. Ovidius' houding in zake het godenvraagstuk is volgens hem in de Metamorphosen geheel anders dan in de erotische werken. In deze laatsten spreekt hij onomwonden uit, dat het geloof aan het bestaan der goden slechts op utilitaire gronden gehandhaafd wordt en moet worden; hiermede verscheurt hij het waas, dat de groote Augusteïsche dichters, in overeenstemming met de politiek van het keizerlijk hof, om hun in den grond rationalistische opvattingen legden (p. 210/1). Doch in de Metamorphosen past hij zich bij hen aan; wij vinden daarin een ,new approach" van Ovidius tot het godenprobleem, en wel om de volgende reden. Ovidius' eigenlijke interesse is de pathologie van den éénen overheerschenden hartstocht in het levenslot der menschen. Niet geremd, voert deze tot een catastrophe. Wijl anders vernietiging dreigt, stellen sommigen een moreele code op om zulke drijvende hartstochten te betoomen. Doch Ovidius is een naturalist, en voor hem is het resultaat van den hartstocht, die tegen alles in zijn weg gaat, niet vernietiging, doch verandering, metamorphose. (Het is daarom geen toeval dat de metamorphosen het onderwerp werden van zijn hoofdwerk.) Dit levensproces ziet Ovidius in de mythen verzinnebeeld, en dat hij het leven zoo interpreteert, geeft hij ondubbelzinnig te verstaan door de mythologische verhalen wetenschappelijk in te lijsten door de cosmogonie in het eerste en Pythagoras' betoog in het laatste boek (p. 227). Omdat de goden "must - in any symbolic scheme of nature - represent a fundamentally serious element in nature since they constitute its constant element", is er in de Metamorphosen een "new approach" tot de goden. Zij hebben meer gehalte; zij zijn de wrekers, en spelen een moreele en oordeelende rol. Het is daarom, volgens $\mathrm{O} t \mathrm{i}$, niet enkel een kwestie van stijl, zooals $\mathrm{He}$ in ze beweert, dat de goden in de Metamorphosen met meer egards behandeld worden. Overigens is $\mathrm{Heinze}$ 's theorie betrekkelijk correct, betrekkelijk omdat de belangrijke uitzonderingen, door Alfred $\mathrm{R}$ ohde vermeld, in rekening gebracht moeten worden. Want het anthropomorphisch element ontbreekt vooral in de eerste boeken niet, waarin o.m. Juppiter een ,irresponsible philanderer" is (p. 221 n. 108 ; p. 225 spreekt $\mathrm{O}$ is van „capricious Olympians”).

Wij zien dus, dat de meeningen sterk uiteenloopend zijn. Nagenoeg het 
eenige punt van overeenkomst is, dat Ovidius' verhalen niets uitstaande hebben met zijn eigen religieuze overturging, dat Ovidius' godenschildening dus primair een litteraire aangelegenherd is Slechts $\mathrm{O}_{\mathrm{t}} \mathrm{s}$ spreekt van symboliek Men kan wel, zooals F a bricius (1896) deed, een systematisch overzicht geven van wat in Ovidius' oeuvre beweerd wordt omtrent de macht der goden over zichzelf en anderen en de natuur, over hun helderziendheid en de beperkingen van hun alwetendheid, over de macht van Juppiter en de verhouding tusschen Juppiter en fatum, daarbij de goddelıke natuur strikt scheidend van de menschelıjke ( $p$ 32), doch daarmede is over Ovidius' religieuze overtuiging niets gezegd Men zoeke in Ovidius allereerst den dichter en de dichterlijke intenties „Ovid's poetic

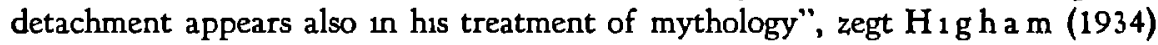
in een zeer waardevol artikel; „To him all myths were the same Old or new, they were nothing more than the fictions of a poet's mind, for poets to handle as they pleased. His only problem was an artist's problem - how to make his figures live." ( $p$ 115)

\section{§2. OVIDIUS POETA}

Blıkens het overzicht der meeningen is de Ovidiaansche godenschildering in de Metamorphosen naar het algemeen gevoelen der litteratuurhistorics (Ot $1 \mathrm{~s}$ uitgezonderd), niet een kwestie van geloof, doch van artistieke uitbeelding, van stijl Dit is een fundamenteele thesis, en deze zal thans nader ontwikkeld en toegelicht worden. Nu vindt de poetische techniek in laatste instantie haar verantwoording in den levensstill des dichters, daarom vraagt allereerst onze aandacht het persoonlijk naturel van Ovidius, den man met zijn hebbelijkheden en overtugingen, zijn levenskijk en zijn eventueele religieuze opvattingen. Van een juist inzicht in 's dichters aard hangt de juste waardeenng af van 's mans godenschildering Wanneer bujv hier en daar een loopje wordt genomen met de goden, maakt het een groot verschil, of een godloochenaar en beeldenstormer aan het woord 1s, dan wel een geloovig mensch met zin voor humor, dan wel een persoonlı,kheid, indifferent voor het wereldraadsel, geabsorbeerd door de poezie van het geval $\mathrm{Nu}$ is het steeds een moellyke opgave, in een karakterschets een persoonlıkkhe1d recht te doen wedervaren, doch bij een uiterst subtiele figuur als Ovidius is dit tot vertwnfelens toe hachelijk. Niemand minder dan R a nd, die ervan doordrongen 1s, dat „Ovid is nothing if not subtle” ( $\mathrm{XI}$ ), erkent, dat ,after all our attempts at analysis, Ovid's spirtt eludes us" (p. 75). De volgende poging tot een schets van Ovidius' levensstyl geven wy dan ook met een bezwaard hart, in het besef, dat zil niet adequaat is, en, in een poging om 's dichters complexen geest niet al te zeer te verminken, onklaar van compositie De moeilykhe1d is niet, op deze schets critiek uit te oefenen, doch om haar waarlyk conform te maken aan het onderwerp. Onze stelling 1s, dat Ovidius' levenskijk en levensstill bepaald worden door naturalisme, scepticisme en poetische drift, dat hij, zelf door geen wereldraadsel gekweld, het spel des levens wil vertolken in het spel der poezie.

Men is het er wel over eens, dat Ovidius naturalist is, met een intense belangstelling voor de concreete zijnsdingen, voor het wonderlijke leven zooals 
het reilt en zeilt. Het leven is één bonte optocht, en Ovidius staat geabsorbeerd toe te kijken, niet vragend naar normen of naar het waarom, accepteerend en genietend. Hierdoorheen speelt een glimlachende scepsis, die „d'ijdelheden hier beneden uitlacht met een lodderoog". De dichter heeft een feilloos instinct voor het groteske, voor de parten, die ons het toeval en onze zwakheden en verlangens spelen. Casus ubique valet (A. 3. 425). Toen Phineus in het strijdgewoel dekking zocht achter het altaar, scelerato profuit ara (5. 37) : zulke dingen komen voor. Al Medea's goede voornemens smelten weg als sneeuw voor de zon, als zij den beminde ziet, et casu solito formosior Aesone natus Illa luce fuit (7. 84/5). Een zanger wordt in den strijd gedood, zijn hand glijdt slap langs de snaren, casuque fuit miserabile carmen (5.118). Een moeder pleit voor haar kindertjes, et casu tendebant bracchia nati (6. 359). De mensch is een wonderlijk samenstel van tegenstrijdigheden : video meliora proboque, Deteriora sequor (7.20/1); nec me sperare fatebar, Sperabam tamen (7.632/3). De opgejaagde stakker is mortemque timens cupidusque moriri (14.215); ne sit scelerata, facit scelus (7. 340); facto pius et sceleratus eodem (3. 5; 9. 408). Hoe weinig weet de mensch, wat hem tot heil strekt; hij vraagt soms om zijn ongeluk perque suam contraque suam salutem $(6.477)$; usque adeo latet utilitas (6. 438). Het leven is vol tragi-comische ironie, en ook de poezie van Ovidius ; het besef hiervan wortelt diep in zijn levenskijk. Ook is het leven, zooals de oplettende waarnemer bespeurt, even subtiel als fantastisch. Naar de behoefte van het oogenblik laakt de sterveling of prijst hij hetzelfde ding. Et mala sunt vicina bonis; errore sub illo Pro vitio virtus crimina saepe tulit (R.A. 323/4). Hoe vaak wijfelen wij niet in ons oordeel? nec utrumque et utrumque videtur (4. 379). Een scherpe grenslijn is dikwijls niet te trekken. Waar is de grens tusschen dag en nacht? quod tu nec tenebras nec posses dicere lucem, Sed cum luce tamen dubiae confinia noctis (4.400/1). Het is een kwestie van subtiele nuances, tenues parvi discriminis umbrae (6. 62); de regenboog is het ideale voorbeeld: in quo diversi niteant cum mille colores, Transitus ipse tamen spectantia lumina fallit; Usque adeo, quod tangit idem est; tamen ultima distant (6. 65/7). Waar eindigt de objectieve waarneming en begint de zinsbegoocheling? aut videt aut acies nostra vidisse putat (H. 17.32). Etsi non cecidit, potuit cecidisse videri (2. 322). Wat is de waarheid? est mihi pro facto saepe, quod esse potest (Am. 2. 13. 6). De een denkt zus, de andere zoo, pars invenit utraque causas (3.255). De mensch heeft stellig alle reden om sceptisch te zijn. Zijn gretig realisme behoedt Ovidius er echter voor, een kleinmoedige scepsis te huldigen. Is het leven al rijk aan zinsbegoochelingen, daarnaast staan feiten, even werkelijk als fantastisch : mira sed acta (F. 3. 370; mira quidem, sed tamen acta, F. 6. 612). Daar is een grot, natura factus an arte, Ambiguum, magis arte tamen (11. 235/6), doch bootst de mensch al de natuur na, soms speelt de natuur ons parten, en een andere grot is arte laboratum nulla: simula verat artem Ingenio natura suo (3. 158/9). Ni sciret fieri, quis nasci posse putaret? (15. 388) Omnia iam fient, fieri quae posse negabam Et nihil est, de quo non sit habenda fides (T. 1. 8. 7/8). De mensch heeft reden om sceptisch te staan zelfs tegenover zijn eigen scepsis. Wat waar is, wat niet waar is, valt 
moeilijk te achterhalen; het leven is een spel, en het leven vraagt om het spel ; laat ons dus spelen. De illusies spelen met ons; laten wij met de illusies spelen : omnia pro veris credam, sint ficta licebit: Cur ego non votis blandiar ipse meis? (Am. 2. 11. 53/4). Wij moeten het leven met gelijke munt betalen. Evenals de Fortuna volubilis, zij ons spel tantum constans in levitate sua (T. 5. 8. 17/8). Levenskunst en levenslust is de kunst van het spel. Niet enkel de ars amandi is een ars ludendi, heel het leven is een flirtation. In het hoogste raffinement ligt het hoogste genot en de hoogste wijsheid. Catullus dichtte een threnodie op den passer, Ovidius eert den psittacus met zijn vox mutandis ingeniosa sonis, boven wien non fuit in terris vocum simulantior ales (Am. 2. 6. 18, 23). Morpheus, de droomgod, is een figuur naar zijn hart, vertolkend niet slechts den gang en het stemgeluid van zijn model, doch ook de overtuigende kleinigheden, de consuetissima cuique verba (11. 637/8) gestumque manus (673), zoodat het droombeeld manifesta lijkt en vera (688/9). Het hoogste raffinement is de ars casu similis (A. 3. 155). Si latet ars, prodest (A. 2.313). Ars faciem dissimulata iuvat (A. 3. 210). De blos op het blank gelaat, si simules, prodest, verus obesse solet (Am. 1. 8. 36). Ebrietas, ut vera nocet, sic ficta iuvabit (A. 1. 597). Veris falso crimine deme fidem (Am. 2. 2. 38). Si culpo, crimen dissimulare putas (Am. 2. 7. 8). 2uo non ars penetrat? (A. 3. 291) Ovidius is verliefd op het bewuste, geacheveerde spel. Wegens des dichters naturalisme mag $M$ ä h l y (p. 137), naar aanleiding van de Ars, Ovidius objectiever noemen dan Horatius, omdat hij niet meet met eenigen maatstaf van een toetsende philosophie doch de toestanden naief schildert zooals zij zijn. Hij heeft echter wel een ideaal, ars, de bekroning van het levensspel. Simplicitas rudis ante fuit (A. 3.113), doch tegenover de toestanden van den oertijd, toen artis adhuc expers et rude volgus erat (F. 2. 292), staat het lichtend heden, waar cultus adest (A. 3. 127), waar ars fit, ubi a teneris crimen condiscitur annis (H. 4. 25). Ovidius verkondigt geen zedelijke normen

Slechts een geboren artiest kan zoo verliefd zijn op de artisticiteit. En hoezeer Ovidius een geboren dichter was, laat zich in begrippen niet weergeven. Murray (p. 116) drukte het uit in gelukkige beeldspraak: „He was a poet utterly in love with poetry : not perhaps with the soul of poetry - to be in love with souls is a feeble and somewhat morbid condition - but the real face and voice and body and clothes and accessories of poetry". Daarbij is de poezie des levens het leven der poezie, spel beantwoordt aan spel, raffinement aan raffinement. Wat van het leven geldt - est mihi pro facto saepe, quod esse potest; cur ego non votis blandiar ipse meis? - , geldt a fortiori van de poezie. De levenskunstenaar speelt met den schijn der werkelijkheid, de dichter met de werkelijkheid van den schijn. Evenals de minnaar, bouwt zich de dichter uit niets een heele wereld op : seu quidquid fecit sive est quodcumque locuta, Maxima de nihilo nascitur historia (Prop. 2. 1. 15/6). Alles, wat Ovidius aanraakt, ook de vruchten van den boom van de kennis van goed en kwaad, krijgt den goudglans der poezie; hij heeft deze gave zoozeer, dat hij, als Midas, ze wel plukt, doch niet tot eten komt. Het wereldraadsel ervaart hij voor zichzelf niet als een brandende kwestie; wat hij wel ervaart, de dichter, wat hem de uiterste realiteit 
1s, rakend den diepsten en verborgen grond van hemzelf, is het mystene van impetus ille sacer, qui vatum pectora nutrit (Ex P. 4.2 25): est deus in nobus, agitante calescimus illo Impetus hic sacrae semina mentrs habet (F. 6 5/6). Wat het ovenge betreft, dat alles is aanleiding tot poezie, het edele en het ijdele (1 n'y a qu'un pas), God of lot Ovidus is vatbaar voor de poezie van den godsdienst, doch hij practiseert den godsdienst der poezie

Slechts vanurt dit gezichtspunt kunnen wij Ovidius' houding begrijpen in zake het godenprobleem. De meest tegenstrudige opvattingen laten zich uit zijn oeuvre samenlezen, en zoowel naar de eene als naar de andere zujde kunnen daarby zijn woorden heel geloofwaardig klınken Laat ons echter bedenken, dat hy, als Morpheus, in staat is de consuetisstma cuique verba te vinden, zoodat men in elk afzonderlyk geval in de verleiding zou kunnen komen, dit als zijn manifeste en waaracht1ge overtuiging te aanvaarden. Doch, zooals men soms den minnaar moet spelen (est tibı agendus amans imitandaque vulnera verbis, A 1 . 611), zoo moet men soms ook den geloovigen of ongeloovigen mensch spelen. Hoe voorzichtig wij moeten zijn by het beoordeelen van Ovidius' uitspraken, leert ons zijn appel aan den ontslapen Augustus: $\tau_{u}$ certe scas hoc, supens ascite, videsque, Caesar, ut est oculis subdita terra tuis. Tu nostras audis inter convexa locatus Sidera, sollicito quas damus ore, preces (Ex P 4. 9 127/30). Dat Ovidius niet gelooft in de apotheose van den verscheiden keizer, behoeft geen bétoog, doch indien dit appel niet tot divus Augustus gencht was, doch tot Juppiter (en dezen aangeduid als summus pater), hoe menigeen zou bezweken zijn voor den toon van oprechtheid Ovidius doet hier, alsof het idee meer voor

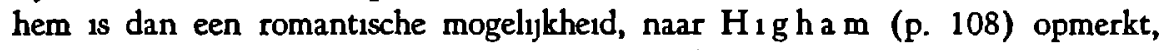
die wijselijk besluit : „Perhaps the poetry of the 1dea appealed to him most”. Deze passage moet ons echter een aanmaning zijn om de uiterste voorzichtigheid te betrachten met andere plaatsen, die ook oprecht klinken (om niet te spreken van : die ons persoonlijk het meest aanspreken), doch waar een correctivum ontbreekt voor onze susceptibliteit. Ovidius kan er heel goed inkomen, dat voor sommigen sine re nomen deus est frustraque tımetur Et stulta populos credultate movet (Am 3. 3. 23/4); de feiten immers wijzen uit, dat Iuppiter igne suo lucos raculatur et arces (35), dat Iuppiter in multos temerana fulmina torquet, $2 u i$ poenam culpa non meruere patı (Ex P $3627 / 8$ ), en zeker: esse deos hic crede (Am. 3.3 1). Aan den anderen kant is het ook zoo begrujpelık, dat de aardworm zich vastklampt aan het geloof in het medelyden der goden : crede mihi, misens caelestia numina parcunt Nec semper laesos et sine fine premunt (Ex P 36 21/2). Hy kent de goedkoope opvatting van godsdienst, volgens welke onthouding en vasten een onding is en festa dies Veneremque vocat cantusque merumque Haec decet ad dominos munera ferre deos (Am. 3. 10 47/8) Doch hij staat ook open voor hooge, spuritueele opvattingen. non bove mactato caelestra numina gaudent, Sed, quae praestanda est et sine teste, fide (H. 19. 181/2). Ut desint vires, tamen est laudanda voluntas Hac ego contentos auguror esse deos Haec fact, ut veniat pauper quoque gratus ad aras, Et placeat caeso non minus agna bove (Ex $P$ 3. 4. 79/82) Wij zijn hier ver van de opvattıng, door de godin Flora geformuleerd : Nos quoque tangit honor, festis 
gaudemus et aris, Turbaque caelestes ambitiosa sumus (F. 5. 297/8). Als naturalist staat Ovidius voor al deze opvattingen open; de scepticus in hem laat de zaak onbeslist (sive mihi casus sive hoc dedit ira deorum, T. 5. 3. 13) ; als dichter dramatiseert hij al deze opvattingen. Goethe verklaarde: „Als Dichter und Künstler bin ich Polytheist" (bij Stemplinger p. 14); als dichter maakt Ovidius gebruik van het motief van twijfel en ongeloof, waar het hem dienstig is, doch verwerpe hij het ongeloof, omdat dit het leven kaal en kil maakt. Voor ons, stervelingen, expedit esse deos et, ut expedit, esse putemus (A. 1. 637); en deze goden moeten in ons leven ingrijpen; met goden, die in ataraxie leven, in secura quies similisque sopori (A. 1. 639), zijn wij niet gediend. Of zij echter ook werkelijk bestaan? Waarom piekeren over zulk een onoplosbaar probleem? Hominum sententia fallax (F. 5. 191). De vraag is niet, of deze opvatting waar is dan wel niet, doch of ons gemoed en onze fantasie ermede gediend zijn, of er copie in zit. Ovidius bindt zich niet aan een bepaalde opvatting ; wie hem hier of elders tracht te fixeeren, omhelst, als Ixion, een looze wolk. Als het voor behoud niet uitdrukkelijk gemaakt wordt, is het impliciet : esse putemus; cur ego non votis blandiar ipse meis? est mihi pro facto saepe, quod esse potest. Pars invenit utraque causas; laten wij naar de opwelling van het oogenblik en de behoefte der situatie kiezen. Het leven is spel, de poezie is spel ; de poezie is. alpha en omega. In dit licht moeten wij ook de passages der Metamorphosen beschouwen, waarin Ovidius het godenprobleem aansnijdt of iets van zijn eigen opvattingen schijnt te zeggen. Ook daar dansen naturalisme, scepsis en poetische dramatisering, als de drie Gratiën, rondom het brandende braambosch.

Het bestaan en het ingrijpen der goden in den cosmos en het leven is natuurlijk de werkhypothese der Metamorphosen. Toch kan de scepticus in Ovidius zich hier en daar een verlichte suggestie niet ontzeggen. Niets is begrijpelijker dan dat de mensch de zee bevolkt met goden, doch als de dichter een oude, romantische tempel beschrijft, trabibus densis lucoque umbrosa vetusto (11. 360), bewoond door Nereus en de Nereiden, voegt hij er ondeugend aan toe : hos navita ponti Edidit esse deos (361/2). Edidit: esse putat. Tot illustratie kan dienen het vers. der Fasti, waar sprake is van een water : si iuvat expertis credere, numen habet (5. 674). Allerwegen in de epiek struikelt men over goden, die ingrijpen in de aardsche actie. De dichter speelt hiermede, als Nestor, vertellend, hoe Theseus een speer ontweek Pallados admonitu, de restrictie maakt : credi sic ipse volebat (12. 360); en van de strijdende Trojanen en Latijnen merkt de dichter op : habetque deos pars utraque, quodque deorum Instar, habent animos (14. 568/9). Daarnaast vinden wij ook opmerkingen, die in positieve richting schijnen te wijzen. Als Midas bekent gezondigd te hebben, komt Bacchus hem te hulp, want mite deum numen (11. 134). Met een beroep op deze woorden verklaart R a nd (p. 74), dat Ovidius "trusts in the gentleness of heaven". Dit is te positief gezegd; Ovidius zou gezegd hebben, dat althans het geval van Midas in die richting wijst. Tot illustratie kan nog een andere opmerking uit de Metamorphosen dienen, en wel in het verhaal van Myrrha. Als deze zich tot de goden wendt met een "o siqua patetis Numina confessis" (10. 483/4), neemt de dichter het verhaal op met : numen confessis aliquod patet, doch hoe wij dit 
moeten interpreteeren, leert ons het vervolg . ultima certe Vota suos habuere deos (488/9) Certe' Leerstelligheid in den strengen zin des woords moeten wij aan deze en dergelıke sententies niet toekennen Indien zulke gedachten balsem zijn voor het hart, cur ego non votzs blandiar ipse mers? In den vorm eener sententie gegoten, zijn zij bovendien zeer geschkt en zeer geliefd ter afsluitıng of ter opening eener episode, vooral bij een keerpunt in de vertelling. Zoo gebruikt Ovidius ook het motief van twiffel aan de hulp of zelfs het bestaan der goden, om aan de peripetie of het sloteffect meer kracht bij te zetten Aeacus, in het verhaal der Myrmidonen, vertelt . querorque In supens opis esse nihal (7 643/4). het is zoo menschelık, doch deze opmerking gaat onmiddellijk vooraf aan de ontdekking van het wonder der goden, en versterkt zoo de penpetie Wil de dichter ons in ons godsvertrouwen versterken? $\mathrm{H}_{\mathrm{j}}$ maakt slechts gebruik van de trag1-comische ronie van het geval om het verhaal te kruiden, en daarbij komt, dat zulke dingen inderdaad voorkomen in het leven met zijn wondere coincidenties Het moorste voorbeeld van dit dichterlyjk spel is de pathetische slotkreet van Hercules' declamatie op den Oeta, die de brandende kwestie schijnt op te werpen van de goddelyke gerechtigheid en van de zegepraal van het kwaad : et sunt, qui credere possint Esse deos 71 (9 203/4) Soortgelıke opmerkingen vinden wij, zooals wij reeds zagen, in Ovidius' werk meer, dergelijke gepeinzen waren, zooals B r a n d t (ad Am 3 3. 25ff) opmerkt, destrjd in de mode, er zit copie in Daarom heeft Hercules hier een acute aanval van atheitss Tevens is zijn kreet de laatste, meest effectvolle vuurpyl van een groot declamatonsch vuurwerk En het pikante is, dat deze twijfelaar op het punt staat zelf god te worden Ludit in humanis divina potentia rebus (Ex P 4 3. 49), en de poezie weerspiegelt deze comedie.

Geloof en ongeloof kruiden den poetischen maaltıd, en speciaal aan den verteller van een krans van verhalen als de Metamorphosen zijn, bieden zij een welkom middel tot binding en bundeling van verhalenreeksen Zoo loopt door een deel van het derde en van het vierde boek als een roode draad de erkenning van Bacchus' goddelijkheid (Schmidt p 21/3). Na den gruwzamen dood van den blasphemischen Pentheus, als heel Thebe den lof van Bacchus zingt (welkome aanleiding om een ruschende hymne ten beste te geven), blivven de Minyeiden verstokt afzijdig, en thuis aan den weefstoel, onderhouden zij elkaar met verhalen Tusschen twee verhalen in heet het: dixerat et factum mirabile ceperat auris, Pars fien potuisse negant, pars omna véros Posse deos memorant: sed non et Bacchus in illis (4 271/3). Deze (en dergelıjke) verzen scheppen niet alleen sfeer, doch houden ook bij den lezer de gedachte aan het grooter verband levendig; zij ziln met trag1-comische urome geladen en geven aan de penpetie, die in het verhaal der Minyeiden zal komen, meer kracht Het behoeft evenwel geen betoog, dat Ovidius nuet in ernst wil vermanen tot geloof aan Bacchus of tegen verstokthe1d des harten Door het motief van geloof en ongeloof wordt ook het bekende verhaal van Philemon en Baucis in den verhalenkrans der Metamorphosen opgenomen Want, aan den feestdisch van Achelous, als de goddelijke gastheer een metamorphose verteld heeft, waann hij zelf betrokken was, maakt Pirthous, deorum Spretor mentisque ferox (8 612/3), de 
grove opmerkung: „Ficta refers nimiumque putas, Acheloe, potentes Esse deos, $s i$ dant adimuntque figuras" (614/5). Hiertegen protesteert vooral Lelex, die hoog opgeeft van der goden macht : ,inmensa est finemque potentia caeli Non habet et, quidquid supen voluere, peractum est" (618/9) Het verhaal van Philemon en Baucis strekt tot bewijs Aldus, door loochening en belijdenis, njgt de dichter het eene verhaal aan het andere Daarbij weet hy aan de omlissting van het verhaal een buzondere charme te geven: de parel knjgt haar passende zetting Niet een ruwe klant als Pinthous, doch de bedaagde en bezonnen Lelex, animo maturus et aevo (617), doet dit verhaal van naef, poetisch volksgeloof, en hy beroept zich op het gezag van eenvoudige, argelooze landslieden. Dit gezag is natuurlyk erg betrekkelijk (esse putant), doch de dichter weet de sfeer te waardeeren, die bij een dergelijke aretalogie het meest passend is. Zooals echter boven reeds bleek, behoudt hij zich de vnjheid voor, elders den verlichten stedeling te spelen

Tenslotte een woord over de twee leerstellige episodes uit de Metamorphosen, het scheppingsverhaal in het eerste en Pythagoras' betoog in het laatste boek. Het is opmerkelijk, hoe de dichter in zijn relaas van de cosmogonie nuet moede wordt te wijzen op de goddelijke hand, die bij de ordening van den chaos in het spel is. Huj spreekt van deus et melior natura (21), van quisquis furt ille deorum (32), van cura der (48), mundi fabncator (57) en ille opifex rerum, mundı melions ongo (79). Ook is nauwelijks een werkwoord te vinden, dat niet deze godheid tot onderwerp heeft ; en tusschen deze overvloedige, met zorg gekozen verba van handeling, die ons geen moment doen vergeten, dat er in deze ontwikkeling een drujvende, ordenende macht is, strooit de dichter ook nog een enkele maal het supreme machtswoord iussit $(37,43,55)$. Hoe moeten wj dit alles waardeeren? Dat de dichter hier de Stoische cosmogonie ontwikkelt, is reeds lang bekend; ampele bewizzen levert de commentaar van $E \mathrm{hwald}$. Toch zal wel niemand in ernst beweren, dat Ovidius een Stoicijn was, of van de waarheid der Stoische leer, althans voor de schepping der wereld, overtungd was De waarheld is, dat deze cosmogonie als de eerste groote, de oer-metamorphose voorgesteld moest worden, want de dichter zou, volgens het prooemium, een krans van gedaanteverwisselingen dichten, tot aan zujn eigen tijd prima $a b$ ongine mund De metamorphosen vragen echter, op artistieke gronden, om een persoonlijk ingnjpen, reden waarom de dichter in de inleidende verzen tot de goden zegt : nam vos mutastis et illa. Moest daarom op artistieke gronden de cosmogonie niet een ontwikkelıng zijn van binnen uit, doch een ordening van buiten af, de Storsche leer bood tot een dergelıjke voorstelling van zaken de behulpzame hand, en de dichter doet het zijne om den lezer in te scherpen, dat dit het werk der godheid is Dit doet hij des te gereeder, omdat hij daarmede van dit leerstuk der popularre phulosophre in vloeiende, didactische verzen een uiteenzetting geeft, welke algemeenen bijval zou oogsten Wil men nog een bewiss, dat Ovidius enkel om artistieke redenen in het scheppingsverhaal der Metamorphosen de godherd pousseert, dan vergelijke men zijn verzen over hetzelfde onderwerp in Ars en Fast, waar hy met geen woord over den alomtegenwoordigen god der Metamorphosen rept (A. $2467 \mathrm{vv}$, F. $1103 \mathrm{vv}$ ) 
$R$ and ( $p$ 74), die ervan doordrongen is, hoe voorzichtig men moet zijn bij het formuleeren van Ovidius' eigen overtuigingen, deed wijs met slechts in voorzichtige termen te gewagen van een vaag monotheisme, dat "may underlie" zijn scheppingsverhaal Maybe not Er zit in elk geval copie in

Naar aanleiding van het beroep op de goden in het prooemium moge $1 \mathrm{k}$ terloops wijzen op een ander beroep op de goden in de Metamorphosen. Van Atlas vertelt Ovidius, dat deze na zijn versteening partes altus in omnes Crevit in inmensum (sic di statuistrs) et omne Cum tot sideribus caelum requievit in illo (4 660/2) Waarom dit beroep op de goden? Omdat de dichter geen rationalistische verklaning wist te geven voor den uitzonderlijken omvang van het gebergte, dat uit een man zou zijn ontstaan, zijn de goden de vluchtheuvel : expedit esse deos

Soortgeliske motieven als bij de inkleeding van de cosmogonie bewogen Ovidius in het laatste boek tot het verwerken van de Pythagoressche leer. Want, in de eerste plaats, is dit een leer van metempsychose en metamorphose, als hoedanig zij den verhalenkrans tot een soort van philosophische basis kan strekken, wel niet onmisbaar, doch curieus Tweedens onderbreekt de leerstellige episode de groote reeks van vertellıngen op aangename wijze, temeer daar de didactische poezie en vogue was Vervolgens neemt de dichter in de uitweidingen en toelichtingen de gelegenherd te baat om nog tal van andere gevallen met metamorphosen aan te stippen En tenslotte ontbreekt ook de actueele noot niet, daar, zooals $R_{1}$ b beck ( $\mathrm{p} 310$ ) naar aanleiding van de declamatie tegen het vleesch. gebrulk reeds opmerkte, in Ovidius' tijd door de prediking van Sextius en Sotion het Pythagoreisme weer opgeld deed Stellig komt daar ook bij, dat de leer van

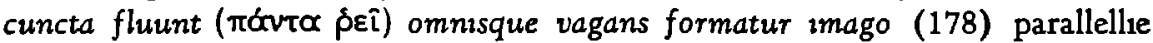
vertoonde met Ovidius' opportunisme, al moeten wij natuurlijk niet te zeer in detals treden voor deze overeenkomst.

Het is kenmerkend voor Ovidius, dat de twee leerstellige episodes der Meta. morphosen haar verklaring vooral vinden in artistieke overwegingen Philosophie en wetenschap zijn ancillae poeseos.

Van een dichter nu, die, artiest in merg en been, in het diepst van zijn hart door de groote problemen niet beroerd, aldus de phenomenen van geloof en ongeloof benut als elementen in het spel der poezie, behoeft het nauwelijks nader betoog, dat hij in denzelfden geest zich de elementen der mythologie ten nutte makkt, gefascineerd, geamuseerd, geinspireerd, doch vrijblijvend. $D_{1}$ quoque carminibus, si fas est dicere, frunt, Tantaque manestas ore canentis eget (Ex P. 4. 8 55/6), zooals de cosmogonie, de gigantomachie, Bacchus en Hercules en, ja ook, ten deele, divus Augustus bewizzen. Wij maken ons natuurlijk geen illusies omtrent de waarheid der mythen Het zijn producten van de fecunda licentia vatum, die exit in inmensum Obligat histonca nec sua verba fide (Am 3.12 41/2). Vele verhalen zijn prodigiosa mendacia vatum. Nec tulit haec umquam nec feret ulla dies (Am 3. 6. 17/8, quae non ulla tulit fertque feretque dies, T. 3 8. 12) $W_{1 j}$ ontzeggen ons het genoegen niet, te coquetteeren met de fantastiek der dichterlijke scheppingen (valeant mendacia vatum, F 6.253 ; $s$ non omna vates Ficta reliquerunt, $13733 / 4$; nisi vatibus omnis Enprenda fides, 
15. 282), want spel is het en tot spel moet het wederkeeren, doch overigens : se non e vero, e bene trovato. Ficta en facta, il n'y a qu'un pas. De hemelingen mogen niet wenen? (neque enim caelestia tingi Ora licet lacrimis, 2. 621/2, cf. neque enim lacrimare deorum est, F. 4. 521) accoord. De eene god mag de daden van een anderen god niet annuleeren? (neque enim licet inrita cuiquam Facta dei fecisse deo, 3. 336/7) uitstekend. De goden halen hun waardigheid door het slijk? aangenaam; laten wij er ons over verheugen; dit brengt ons weer in de vertrouwde sfeer der beminnelijke gebreken van ons, stervelingen. Dat wij van die hooge wezens, bijv. van ille pater rectorque deum, cui dextra trisulcis Ignibus armata est, qui nutu concutit orbem (2 .848/9), eigenlijk verhevenheid mochten verwachten, doch dat de mythen ons anders leeren (Iuppiter infamat seque suamque domum. Prop. 3. 11. 28), verhoogt de pikanterie en het genot. Euripides,

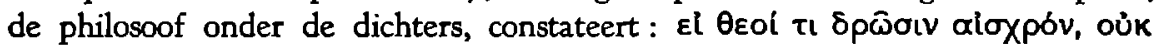
Eloiv $\theta e O l$. De liefdesdichter bekent van den verliefden Apollo: fabula nunc ille est, sed cui sua cura puella, Fabula sit mavult quam sine amore deus (Tib. 2. 3. 31/2). De opvatting van Ovidius, den poeet pur sang, kan, met een lichte wijziging, aldus worden weergegeven : fabula nunc deus est, sed cui sua cura poesis, Fabula sit mavult quam sine labe deus. In het licht van wat boven is betoogd, is het zonneklaar, dat Ovidius zich geen zotternij of spotternij ten koste van de goden zal ontzeggen, doch ook, dat hij, waar hij dit doet, speelt en in d'ijdelheden van hierboven zich vroolijk maakt om d'ijdelheden hier beneden. De verhalen zijn lusus gravitate carentes (Ex P. 1. 9. 9). Daarbij mag de spot soms gerust naar de satire zweemen, want waar de luim naar ernst zweemt, wordt het spel het pikantst. Om den iconoclast te spelen, behoeft men het nog niet te zijn. Ovidius is indifferent voor de waarheid, zijn houding wordt bepaald door de mogelijkheden en behoeften van het oogenblik voor de poezie en het spel. $\mathrm{Hij}$ is de dichter van het hic et nunc: oogenblik gaat voor eeuwig.

De Ovidiaansche godenschildering in de Metamorphosen is dus inderdaad een kwestie van poezie, van stijl, niet van geloof. Ons onderwerp is een litteraire aangelegenheid.

\section{§ 3 : OVIDIUS VOLTOOIER VAN HET ALEXANDRINISME TE ROME}

Het onderzoek van Ovidius' godenschildering in de Metamorphosen is een litteraire studie. Nadat wij een ruwe schets gegeven hebben van Ovidius' persoonlijkheid en naturel, dienen wij thans de plaats te bepalen van den dichter, van de Metamorphosen in het bijzonder, in de ontwikkeling der Romeinsche litteratuur. Ovidius is in de Metamorphosen en in de Fasti de voltooier van de neoterische, dat is alexandrijnsche aspiraties te Rome.

Hij is dit in de eerste plaats vorm-technisch, zooals door Martini in een belangwekkend artikel (O. B.) is uiteengezet, waarvan ik hier de hoofdpunten kortelijk zal refereeren.

De eigenlijke en typische richting der alexandrijnsche poezie is die van de ontwikkeling en vervolmaking der kleine, zelfstandige composities, welke in de plaats treden van de groote litteraire vormen van het klassieke tijdperk. Zoo 
treedt op het gebied der epiek in de plaats van het groote epos het epyllion, waarvan Callimachus' Hecale het meest bekende voorbeeld is. Naast deze kleine zelfstandige composities evenwel vinden wij ook omvangrijker composities; men denke, op elegisch gebied, slechts aan Callimachus' Aetia, op episch gebied, aan Nicander's Heteroeumena. De tegenstelling met de kleine zelfstandige composities is slechts schijnbaar, want deze groote werken zijn niet één groot organisch geheel, doch in feite een krans van afzonderlijke, zelfstandige eenheden, die onder een bepaald gezichtspunt zijn saamgevat. Dit beteekent niet, dat de Alexandrijnen zonder meer tot het catalooggedicht van Hesiodus zijn terug. gekeerd; wegens de kunst van samenstelling, die zij hierin aan den dag leggen, spreekt $\mathrm{M}$ a r t in i van collectief gedicht. De Alexandrijnen zijn namelijk bedacht, eenerzijds, op een kunstige verbinding der afzonderlijke deelen, die in het algemeen niet door een stereotype formule aaneengeschakeld, doch nu eens door deze, dan weer door gene kunstgreep, nu paratactisch, dan hypotactisch (zoodat kleinere cycli ontstaan binnen den grooteren cyclus) verbonden worden, anderzijds op een kunstige vormgeving van de afzonderlijke deelen, die nu eens lang uitgesponnen, dan weer kort gerefereerd, hier in dezen stijl, ginds in een anderen stijl ontwikkeld worden. Daarom is het groote collectieve gedicht, speciaal het epische en het elegisch-narratieve, de hoogste kunstvorm der Alexandrijnsche richting.

In Rome nu, reageerend tegen den sleur der Enniaansche school, hebben de neoterici, in systematische imitatie hunner Grieksche meesters, alle soorten van het korte, zelfstandige gedicht, op episch gebied het epyllion, op Romeinschen bodem overgeplant; aan het groote collectieve gedicht evenwel waagden zij zich nog niet. Van de Augusteïsche dichters oriënteerde zich een deel, met Vergilius en Horatius aan de spits, weer op de oud-helleensche klassieken, Vergilius echter niet alvorens het bucolische genre voor de Latijnsche litteratuur vermeesterd te hebben; anderen echter traden in het voetspoor der neoterici en bouwden de moderne litteratuur verder uit: de elegiaci brachten de subjectieferotische elegie tot hoogsten bloei, Propertius waagde zich ook aan de narratieve elegie, doch zijn groote collectieve gedicht in elegische maat bleef in zijn aanvang steken. Dan echter komt Ovidius, die, na in zijn eerste, erotische periode de uiterste mogelijkheden van de erotische elegie tot ontwikkeling gebracht te hebben, daarop in zijn Metamorphosen en Fasti den Romeinen ook de hoogste vormen schonk der moderne kunst, zoowel het epische als het elegisch-narratieve collectieve gedicht. Bij hem vinden wij dezelfde principes toegepast als bij de Alexandrijnen, kunstige verbinding der afzonderlijke deelen, en bonte vorming der afzonderlijke bouwsteenen. Zoo is Ovidius, naar Martini betoogt, de voltooier der neoterische aspiraties.

Doch niet alleen zijn poetische techniek, ook zijn innerlijke structuur is modern en alexandrijnsch, en daarom juist is hij de voltooier van het alexandrinisme te Rome. In de eerste plaats vindt dit natuurlijk zijn verklaring in het naturel van Ovidius, zooals dit in de voorafgaande paragraaf is aangeduid. Daarbij komt vervolgens (en dit willen wij in het volgende nader aanduiden), dat bij Ovidius' verschijnen de voorwaarden vervuld waren, die een voldragen 
alexandrijnsche kunst, waarbij vorm en geest adequaat zijn, te Rome mogelijk maakten.

Dat de alexandrijnsche beweging in de Grieksche letteren niet louter een aesthetische aangelegenheid was, doch dat zij wortelde in structureele veranderingen in het Grieksche geestesleven, is onder meer, in een kostelijk boekske, door Legra nd uiteengezet, naar wien verwezen zij. In Rome nu voltrok zich gedurende de laatste decennia der republiek, en vervolgens onder Augustus' regeering eveneens een kentering in verhoudingen en opvattingen. Wat vroeger burgers geweest waren, werden, door de alleenheerschappij, ook door den gematigden vorm ervan, het principaat, tot onderdanen. Het veld der zelfstandige politieke activiteit ging voor de Romeinen verloren, en in het particuliere en sociale leven, niet in de laatste plaats in de litteratuur, werd een recompensatie gezocht voor de vrijgekomen energieën. Persoonlijke emoties en persoonlijke verhoudingen komen op den voorgrond te staan. De litteratuur wordt een hoogere vorm van genoegen en spel, de tijd is rijp voor de kunst om de kunst. Typeerend voor deze ontwikkeling van zaken is Asinius Pollio, die, door de omstandigheden uit de groote politiek verdrongen, voor het verlorene en voor zijn energie afleiding zocht in de recitationes; deze vervingen de beraadslagingen in den senaat en de volksvergadering van voorheen. $\mathrm{Na}$ Vergilius raakte de litteratuur verbijsterend snel los van het eigenlijk politieke leven van Rome. Een prinselijk huwelijk, in Ovidius' dagen, zoo merkt L eo (p. 353) op, nam in het leven der metropool de plaats in van de groote politieke evenementen van weleer. Dit nu was voor Catullus en zijn kring nog niet het geval. Ondanks hun litteratendom waren zij nog steeds republikeinsche burgers en geen onderdanen, en al wierp hun litterair otium, historisch gezien, den schaduw der komende toestanden vooruit, in hun eigen tijd was hun houding een reactie, en niet de normale gang van zaken. Calvus was, naast dichter, ook redenaar.

In de tweede plaats kan de tijd van Ovidius terugzien op een eigen Romeinsche, groote, klassieke litteratuur. De groote opgaven zijn volbracht, de ontwikkelingsmogelijkheden der taal zijn tot ontplooiing gebracht. Dit is hierom van zoo eminent belang, omdat de alexandrijnsche poezie, al heeft zij andere idealen, op den ondergrond van een rijk litterair verleden bouwt. Ovidius vindt, ook in zijn eigen taal, vormvolmaakte werken, en niet een enkel, doch talrijke, en niet in één, doch in alle belangrijke genre's. Tot zijn beschikking staan, om slechts de voornaamsten te noemen, voor bucoliek en epiek een Vergilius, voor de lyriek een Catullus en Horatius, voor de elegie een Tibullus, een Propertius en een Gallus, voor het epigram en de moderne kleine compositie een Catullus, een Calvus en hoe de neoterici verder mogen heeten, voor het philosophisch leerdicht een Lucretius, om van de oudere dichters, epici, tragici en comici nog niet te spreken. Een Ovidius laat dezen rijkdom niet onbenut. Geheel anders waren de zaken gesteld voor de generatie van Catullus, die, in de eigen taal, voor het epische genre slechts een Ennius arte carens (Ov. Am. 1. 15.19) en diens epigonen en voorts de tragici tot haar beschikking had, die met een taal moest opereeren, welke aan haar idealen niet beantwoordde en er ook nog niet rijp voor was, die nog te veel te worstelen had om waarlijk te kunnen spelen. 
Weliswaar is het verschil net enkel tot het phraseologisch gebied beperkt, doch op phraseologisch gebied openbaart zich het onderscheid tusschen een Catullus en een Ovidius welsprekend Treffend zijn bij Catullus, den reactionnair, den fellen dichter van den nieuwen still, de vele Ennianismen $Z_{1 j}$ zijn gewild! het behoorde tot de alexandrinsche techniek, in eigen gedichten remuniscenties te verweven aan de groote ouden Hiertoe kwamen voor Catullus vader Ennius en de tragici in aanmerking Hoe beperkt echter is zijn keuze, vergeleken bij die van Ovidius, bij wien zich de reminiscenties aan tal van schnjvers op zoo in het oog vallende wijze verdringen, dat er reeds lang geleden een uitgebreide verzameling werd aangelegd door $Z_{1}$ g e $r$ le, een verzameling, die niet zonder aanvullingen bleef

Zoo vond Ovidius, bij zijn verschynen, de voorwaarden vervuld, die een bekroning der alexandrunsche beweging te Rome mogelık maakten $\mathrm{H}_{1 \mathrm{j}}$ eerst kan net alleen de allure, doch ook de waarlijk natuurlyke, ongeforceerde, urt den geest des tijds voortsprutende geestesinstelling hebben der alexandrijnsche meesters, en hij eerst heeft in zijn eigen taal de noodige middelen tot zijn beschikking om deze bekroning der neoterische aspiraties zonder overmatig worstelen met een weerbarstige materie spelenderwijs tot stand te brengen Daarbij sluit zıch het naturel des dichters op de gelukkigste wijze aan : wars van politiek, beschouwer van het leven, aestheet in merg en been, moest hy zich uiteraard aan de alexandnjnen verwant voelen. Tusschen Ovidius' aanleg en het alexandrinisme bestond, naar De la Ville de Mirmont opmerkt (zie onder het overzicht der meeningen, ook L a f a ye), een "harmonie préétablie". Door zichzelf te zijn, is Ovidius de exponent van den geest van zijn tijd $H_{1 j}$ kon naar waarheid verklaren: prisca iuvent alios, ego me nunc denque natum Gratulor haec aetas moribus apta mers (Ars $3121 \mathrm{v}$ ) Voor zijn generatıe geldt, dat de tuden rup waren voor de moderne geesteshouding en kunst, doch persoonlyjk was hij krachtens zijn geaardhe1d de aangewezen man om op het Romeunsch alexan. drinisme de kroon te zetten Dat hy zich bewust bij de alexandrijnsche dichters aansluit, kan men bij verschillende gelegenheden in zijn poezie bewizzen; in de bespreking der verhalen uit de Metamorphosen zullen wrj enkele malen de gelegenherd hebben erop te wijzen.

Ovidius' alexandrinisme beteekent niet slaafsche afhankelıkheid van zi1n alexandnjnsche meesters $\mathrm{De}$ alexandrijnsche dichtwerken zijn voor hem niet louter of in hoofdzaak modellen, welke te copieeren hij zijn hoogsten roem acht, doch een erfenis $\mathrm{H}_{1}$ is niet an hun middelen gebonden, hy realiseert hun principes op eigen wizze, zelfstandig $\mathrm{H}_{1}$ doet dit ook daar, waar hy een alexandnjnsch voorbeeld voor oogen heeft Als illustratie hiervan kan dienen, om buiten de godenverhalen te blyven, zijn schildenng van Aeetes, als Jason de vuursnuivende stieren bedwingt, vergeleken met die van Apollonius Rhodius (Ov. 7. $102 \mathrm{v} ;$ Ap Rh $31225 \mathrm{vv}, 1275 \mathrm{vv}$ ) Zooals niet anders verwacht kon worden, kent Ovidius het werk van Apollonius (Ehwald ad 6.706) Blj Ovidius nu slaat de Colchische konung het schouwspel gade, te midden van de schare gezeten, in het purper gekleed; by Apollonius vat hij post. Ovdius vermeldt, als teeken zijner wardigheid, de ivoren scepter, bij Apollonius is de koning in 
volle wapenrusting aanwezig. De afwijking is kenmerkend: Ovidius wekt den indruk, dat Aeëtes in Romeinschen trant als imperator de kampspelen bijwoont. Zoellner (p. 39 v.), alle mogelijke overeenkomsten tusschen beide dichters opsommend, verzuimt het beslissend verschil te vermelden, de romaniseering door Ovidius.

In Ovidius' werken is ook de alexandrijnsche richting der Romeinsche litteratuur geëmancipeerd. Ampele bewijzen zullen de komende besprekingen der verhalen leveren. Hier willen wij deze stelling nog met een enkel voorbeeld demonstreeren, Catullus met Ovidius vergelijkend, en wel aan de hand van de moderniseering, een der meest opvallende eigenaardigheden der alexandrijnsche poezie. Ook in verhalen, welke zich in mythische tijden afspelen, vinden wij allerwegen opvattingen en toestanden geprojecteerd uit 's dichters eigen tijd en omgeving. Voor de litteraten van het Diadochentijdperk waren dat de toestanden der nieuwe Grieksche hoofdsteden. Bij een Romeinschen dichter behoren het de toestanden te zijn van het Rome van zijn eigen tijd. Wat zien wij echter bij Catullus, die hierin ongetwijfeld de representant is van geheel zijn generatie? Hij brengt het principe der moderniseering niet in toepassing met eigen Romeinsche middelen, doch copieert de middelen zijner Grieksche modellen, waarmede hij in feite het veelgeprezen principe met voeten treedt ; hij bestendigt een verouderde situatie. Zoo kon het geschieden, dat $R$. R e itzenste in in Catullus' epyllion plaatsen kon aanwijzen, die apert toestanden veronderstelden, welke aan de hoven der diadochen bestonden (zie ook $\mathrm{K} \mathrm{r}$ oll in zijn commentaar op carmen 64, vooral de inleiding erop en de noten bij vv. 43, 278, 280). De beschrijving van Peleus' paleis bijv. en van de kijkgrage volksdrommen vinden zulke frappante analogieën in beschrijvingen van vorstelijke feesten te Alexandrië, dat Reitzenstein zelfs de theorie heeft geopperd, dat Catullus' Grieksch model voor een koninklijke bruiloft bestemd was. Men kan, om het ontbreken van de Romeinsche sfeer beter gewaar te worden, Catullus' beschrijving vergelijken met de bruiloft in Statius' Thebais (2.213 vv.), waar onder meer van imagines sprake is. Catullus realiseerde het principe der moderniseering niet, maar copieerde, onzelfstandig, de middelen van voorgangers, daar hij aan het stadium der imitatie nog niet ontgroeid was, al zocht hij in andere opzichten reeds eigen wegen. Waar echter Ovidius van paleizen spreekt en koninklijke bruiloften, ook op Griekschen bodem, ademt men evenzeer de sfeer van het Augusteïsch Rome als bij de alexandrijnsche dichters de sfeer van den diadochentijd. Ovidius' Olympus en gastmaal van Achelous zullen later besproken worden; hier moge ik slechts verwijzen naar het feest bij Theseus' behouden terugkeer (7.430 vv. : o.a. patres, vota publica; de situatie herinnert aan Callimachus' beroemde Hecale, Ehwald ad 434), naar het paleis van Aeacus (7.644 vv.: salutatio), en naar de bruiloft van Tereus en Progne ( 6.435 vv.: hier denke men aan de prinselijke bruiloft, waarover Le o boven geciteerd werd). Niet de middelen, maar het principe neemt Ovidius over, het principe op eigen gelegenheid realiseerend, de middelen ontleenend aan zijn eigen stad en tijd. Laudamus veteres, sed nostris utimur annis (Fast. 1. 225).

Treffend is ook het verschil tusschen Catullus en Ovidius in de teekening 
van Ariadne. Mitra, amictus, strophium (64.63 vv.), elk kunstig van een epitheton voorzien, zijn misschien geschikt om ons een denkbeeld te geven van een beeld ; doch Ovidius' tunica velata recincta (Ars 1.529) teekent kort maar feilloos een Romeinsche puella. Wie hieraan mocht twijfelen, herinnere zich, dat Corinna, 's dichters lief, wier moderniteit niets te wenschen overlaat, haar dichter met een bezoek vereert, eveneens tunica velata recincta (Am. 1.5.9). Catullus' precieuze verzen smaken naar een Grieksch voorbeeld, Ovidius weet met een enkele gelukkige opmerking de sfeer van zijn eigen tijd te treffen. Catullus is nog grootendeels imitator, Ovidius schepper en herschepper, eerstgenoemde is nog gezel, de laatste eigen heer en meester.

\section{§ 4. ALEXANDRIJNSCHE GODENSCHILDERING}

Ovidius is de voltooier van het alexandrinisme te Rome. Rest ons dus, alvorens de Ovidiaansche godenschildering in de Metamorphosen te bestudeeren, een schets te geven van de godenschildering door zijn Grieksche en Romeinsche voorgangers. Wij mogen verwachten, bij hen dezelfde kenmerken terug te vinden als bij Ovidius.

Voor Ovidius zijn de goden voorwerpen van poezie, en niet van geloof. Voor de alexandrijnsche dichters geldt hetzelfde. „Formal orthodoxy was its policy - orthodoxy, because many centuries had so accumulated myth and dogma that theology was a welcome and inexhaustible field to the learning of the pedant, to learning without originality ; formal too, like that of the cinquecento, for the learned would not deny themselves the pleasure or the liberty of sneering at earnest faith, and ridiculing the intellectual weakness of the faithful. These fellows and professors of the Hellenistic university were, in fact, orthodox because they were not religious, and because they preferred explaining religion as interesting archaeology to adopting it as a rule of life" (M a h a f f y p. 260/1). Het algemeen gevoelen der geleerden wordt bondig weergegeven door A. Croiset: „De l'esprit, sans aucun mélange de piété" (p. 218). Slechts $\mathrm{S} t$ a e he $\mathrm{i}$ in, in zijn studie over Callimachus' religie, wijst met klem de opvatting af, dat deze dichter a-religieus is. Volgens hem is hij niet anti-religieus en niet a-religieus, doch erkent hij het goddelijke wel, al heeft al het rationeele en empirische in de overgeleverde religie bij hem zijn rol uitgespeeld (p. 61) en al verzet de dichter zich tegen elk spoor van dogmatisme. Sta e hel in ziet in Callimachus een soort vrijzinnig Protestant onder de Grieken : ontvankelijk voor religieuze aandoeningen, wiens religie bestaat in een vage, vormelooze religiositeit, of psychische onrust. Overigens erkent ook Staehelin, dat de mythologie bij Callimachus geheel tot een aangelegenheid der poezie is geworden (p. 13); zij is een cultururgoed, dat den artiest ter harte gaat. Callimachus is dan ook ( $\mathrm{S}$ ta ehelin p. 9 en 31/2; Von $\mathrm{Christ}-\mathrm{S} \mathrm{chmid}$ p. 137) een tegenstander van het Euhemerisme. Fr. 10 Pf. schijnt in deze richting te wijzen. Het beroep op de verzen 8/9 der Zeus-hymne is op zich niet steekhoudend :

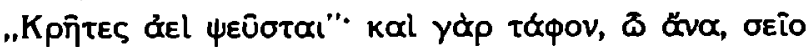

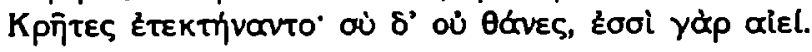


Wij halen deze verzen hierom aan, omdat zij kenmerkend zijn voor de houding van Callimachus : beslissend is het moment der geleerdheid, dat bij hem even onmiskenbaar aanwezig is als het religieuze moment vaag. De dichter coquetteert met zijn geleerdheid. Het Euhemeristisch pragmatisme staat hem niet zoo erg tegen, of hij kan er mee spelen. Tevens glimlacht hij over de naieviteit van de geloovige „,weerlegging". Ditzelfde coquetteeren met geleerdheid, onder het mom van religiositeit, treffen wij ook in de Aetia, in het beroemde verhaal van Acontius en Cydippe : (Ox. Pap. 1011, fol. 1 verso 4/9)

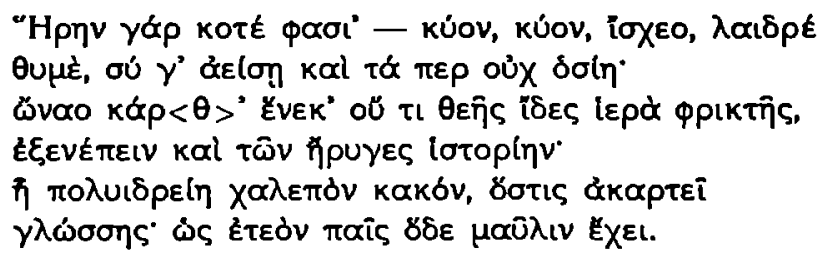

„Echt kallimacheisch ist, wenn er die Geschichte von Hera - niemand kennt sie und alle sind gespannt - nun gerade nicht erzählt, schalkhaft ein religiöses Bedenken vorschützend" (Aly p. 237/8). Het is dan ook niet te verwonderen, dat de goden der kunst in de Aetia familiair met den dichter omgaan. Apollo vermaant hem : (Ox. Pap. 2079, fr. 1. 23/4)

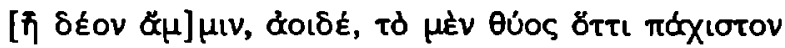

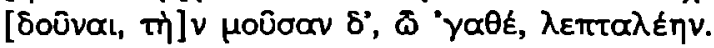

Men vergelijke Vergilius'
cum canerem reges et proelia, Cynthius aurem Ecl. 6.3
vellit et admonuit: 'pastorem Tityre pinguis
pascere oportet ovis, deductum dicere carmen.'

Aurem vellit is een goede illustratie van de schalksche familiariteit, die ook bij Callimachus den god kenmerkt. Ongedwongen ook gaan de Muzen met haar zanger om: (Ox. Pap. 2080, Col. 2. 58/9)

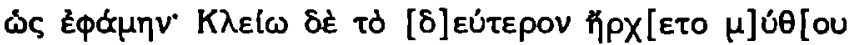

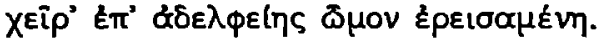

De mythen, naar het leven uitgewerkt, geven den dichter gelegenheid tot geleerd vertoon, en, door het contrast tusschen goddelijke hoogheid en feitelijke kleinmenschelijke gewoonheid, tot een prikkelend spel met vroomheid en verlichtheid; de artiest kan er zijn hart aan ophalen. Van religiositeit is echter geen sprake; het alexandrinisme is zedelijk indifferent (Von $\mathrm{Christ} \cdot \mathrm{Schmid}$ p. 27 n. 3). Hoe wij ook de Homerische godenschildering moeten beoordeelen, de alexandrijnsche godenschildering is een artistieke aangelegenheid.

Ovidius' godenschildering wordt, blijkens het overzicht der meeningen, gekenmerkt door de volgende vier momenten : vermenschelijking, moderniseering, spel met de dupliciteit van eponyme godheden, humor en ironie. Hetzelfde geldt van de alexandrijnsche godenschildering. Wij zullen hiervan enkele voorbeelden 
geven, gesteund door uitspraken van litteratuurhistorici. De illustratie kan echter niet 200 rijk en uitgebreid zijn als wenschelijk is. Dit is te wijten aan de schaarschte onzer bronnen, waarover hier een enkel woord gezegd zij. Van de alexandrijnsche poezie is ons slechts weinig gebleven. Van hoofdwerken als Callimachus' Hecale en Aetia bezitten wij slechts fragmenten; verschillende verhalen uit een werk als Nicander's Heteroeumena, die door Ovidius meer dan eens, en niet slechts in details, benut zijn, hebben ons slechts in korte referaten bereikt. Speciaal op het gebied der godenliefdes is ons nauwelijks iets direct overgeleverd. Wij moeten ons illustratiemateriaal trekken uit de merkwaardige hymnen van Callimachus, - die verschillende hebbelijkheden der godenschildering in hooge mate vertoonen, doch waarin wegens het hymnisch karakter de dichter zich niet zoo vrijelijk kon bewegen als bijv. een Ovidius in de Metamorphosen of een Nicander in de Heteroeumena -, uit de Argonautica van Apollonius Rhodius, en verder uit verspreide opmerkingen bij Theocritus en de andere bucolici; het is een schrale troost, dat in Moschus' Europea althans eenig licht geworpen wordt op den goddelijken verleider. Wij zijn daarom wel gedwongen uit te zien naar aanvullend materiaal, en dit wordt ons geboden door vergelijkende bronnenstudies over Romeinsche en Grieksche post-alexandrijnsche auteurs, zooals deze gemaakt zijn o.m. door $\mathrm{Kna}$ a ck, $\mathrm{C}$ a st ig lio n $\mathrm{i}$ en Reitzenstein R., waaruit met eenige zekerheid of waarschijnlijkheid is komen vast te staan, dat bepaalde motieven bij hun navolgers op de alexandrijnsche dichters teruggaan. Nochtans zijn de bezwaren niet gering. Willekeur vierde niet zelden hoogtij bij dergelijke bronnenstudies (zie bijv. onder de bespreking van „Daphne"); de resultaten van dergelijke onderzoekingen, zelfs als daarin de uiterste behoedzaamheid is betracht, zijn problematisch, problematischer naarmate men de resultaten scherper fixeeren wil of op een bepaalden dichter in een bepaald dichtwerk herleiden; en vervolgens, ook al mochten de resultaten onaanvechtbaar zijn, dan nog missen wij noode de exacte inkleeding en verwoording van elke scene en elk motief, de vele kleine details, de suggestie van woordkeuze en rythme, die vaak van doorslaggevend belang zijn. Wegens de schaarschte onzer directe gegevens op het gebied der eigenlijke godenschildering echter zullen wij ons hier en daar beroepen op indirecte gegevens of ook wel buiten het gebied der eigenlijke godenschildering treden, iets wat zeer zeker geoorloofd is om de algemeene tendenzen te verduidelijken, aangezien er geen twist is onder de geleerden hierover, dat goden- en heldenschildering hand in hand gaan, en dat wij de algemeene kenmerken der alexandrijnsche poezie in de godenschildering terugvinden.

\section{Vermenschelijking.}

Wat in de alexandrijnsche poezie, ook in de godenschildering, het meest in het oog springt en reeds lang en algemeen is opgemerkt, is de tendens tot realisme en schildering van het alledaagsche, bij de goden vermenschelijking en als het ware verburgerlijking (Couat p. 357,381+n. 1; Cahen p.614; Legrand p. 48 v.; Herter p. 56). Huber in zijn voortreffelijke dissertatie heeft aangetoond, dat de genreschildering bij de alexandrijnsche dichters doel in 
zichzelf vormde. Bijna alleen de namen herinneren ons eraan, dat er van wezens van hoogere orde verteld wordt (Herter p. 85). Vooral de Artemishymne levert hiervan talrijke bewijzen. Bijvoorbeeld: Artemis vraagt aan Zeus om bepaalde gunsten. Hoe is deze scene ingekleed? Alle verhevenheid is zoek: Artemis is een klein, kinderlijk babbelend meisje, zittend op vaders knie, vergeefs de kleine armpjes uitstrekkend naar zijn baard (,baby": Bethe G. L. p. 50); Zeus is niet de opperbestierder, doch huisvader, gelukkig met zijn veelbelovende jonge dochter, wier vragen hij in kinderlijken trant beantwoordt. In dezelfde hymne horen wij van een bezoek van Leto met de kleine aan de smidse van oome Hephaestus om de $3 \pi$ tifpla voor de kleine te krijgen, - een menschelijk gebruik, aan de hemelschen toegeschreven. Ook op den Olympus zijn de godenkindertjes soms stout, zoo leert ons hetzelfde dichtwerk, en dan komt Hermes, de bediende, het gezicht met asch besmeerd, voor boeman spelen (Herter p. 82). De Aphrodite uit het „Bad van Pallas" wordt als een ware modegekkin geteekend (Thomann p. 10). Leto, in de Deloshymne, is een arme verschoppeling, Hera een grimmige meesteres, voor wie het dienstmeisje, Iris, doodsbenauwd is, wier klappen zij vreest, aan wier voeten zij zit, klaarwakker, als een jachthond met gespitste ooren, om op elk moment op de bevelen harer meesteres te vliegen. Bekend zijn vooral de Olympische scenes aan het begin van Apollonius' derde boek. De scene, waarin Aphrodite aan de toilettafel verrast wordt, herinnert aan het kleinburgerlijk philisterdom van Alexandrië (Kö r t e p. 169; B e th e G. D. p. 315), en aan de mime (De la Ville de Mirmont M. D. p.617 en 622 ; Huber p. 53 v.), vooral als het gesprek komt op den verwenden lummel, Eros, tegenover wien de moeder machteloos staat, dien zij moet paaien met een heel mooien speelbal (B e th e p. 315 ; V on All m e n p. 36). Het is zoo niet te verwonderen, dat zelfs de Priapen des velds in de vermenschelijking deelen, en er rouwkleeren op na houden (epithaph. Bionis 27). De goden zijn in vergelijking met de menschen, volgens de euphemistische formuleering van $\mathrm{Heumann} \mathrm{p.} 47$ v.,

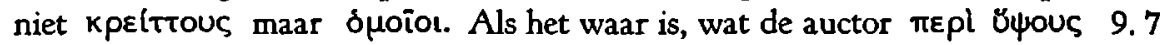
van Homerus zegt, dat hij de goden tot menschen gemaakt heeft, is de term ver. menschelijking voor de alexandrijnsche godenschildering nauwelijks adequaat te noemen.

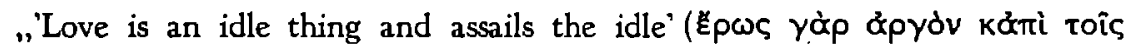
apyoic $k q u)$. Euripides himself had written. Alexandria may be held to illustrate the dictum" ( $\mathrm{Hardi}$ e p. $146 \mathrm{v}$.). Wat van de alexandrijnsche dichters geldt, geldt ook van hun goden, in wier leven de liefde een meer dan voorname plaats inneemt. De erotiek is het sap van de alexandrijnsche poezie (Bethe G. L. p. 39). De alexandrijnsche dichters hebben niet zoozeer belangstelling voor het genealogisch resultaat der godenverbintenissen alswel voor de verliefdheid zelve, haar kracht en haar symptomen (E. R oh de p. 114 v.). De hooge Apollo wordt

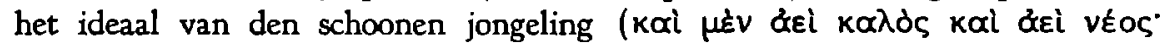

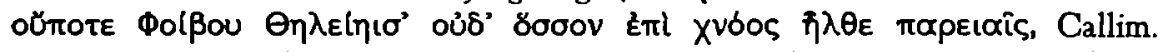
Apollohymne $36 \mathrm{v}$.). Kenmerkend voor heel de dichterbent is, dat de dienstbaarheid van dezen god aan Admetus, bij Euripides nog een straf van Zeus, door Rhianus, en vervolgens door alle dichters, te beginnen met Callimachus, aan 
verliefdheid van Apollo wordt toegeschreven (Rhianus in schol. Eurip. Alc. 1; Callim. h. 2. 49). De liefde beheerscht het gedrag der goden; zij verkiezen boven den hemel het gezelschap hunner aardsche lievelingen, en verwaarloozen hiervoor hun cultusplaatsen (Castiglion i p. 132, 180/207; zie onder "Admetus" en „Hyacinthus”). De menschelijke verleidingskunsten zijn aan de goden niet vreemd id. p. 179 v.); zij dragen voor de geliefde op de jacht bijv. de netten. Waar overreding niet baat, worden geweld en bedrog gebruikt. De goden namen, volgens de oude opvattingen, in hun omgang met aardsche vrouwen vaak een vermomming aan, daar de stervelingen den aanblik der onverhulde godheid niet konden verdragen; bij de alexandrijnsche dichters wordt de vermomming tot een perfied middel om tot het doel te geraken (Peters p. 76): want, zooals de

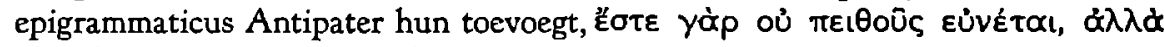
Bíns (Anth. Plan. 9. 241.4). Vooral Zeus is de kampioen der liefde zoowel

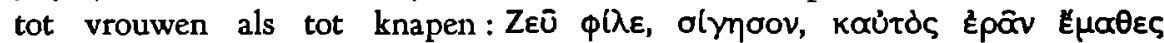

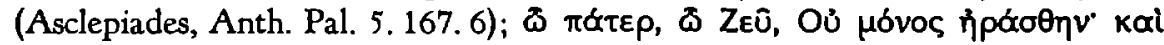

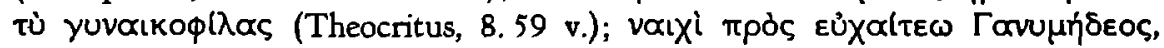

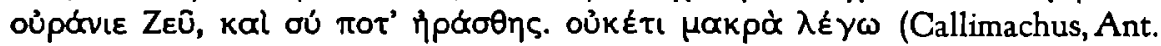
Pal. 12. 238. 2 v.): commentaar overbodig !

Hand in hand met Zeus' begeerlijkheid gaat Hera's naijver. Zeus horen wij hierover zuchten in de Artemishymne (30 v.). In de Deloshymne beroert zij

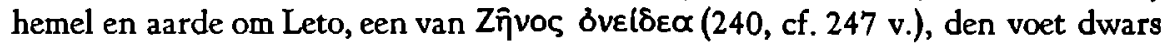
te zetten. Bij Moschus neemt Zeus de gedaante van een stier aan, deels om Europa te misleiden, deels om den toorn te ontwijken van naijverige Hera (Europea 77). Fijntjes teekent Hera bij Apollonius in een gesprek met Thetis

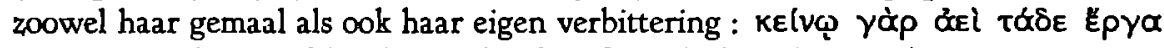

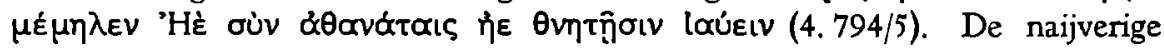
Hera in de Callistosage schijnt eerst uit den alexandrijnschen tijd te stammen (Heinze p. 106).

De goden zijn aan de liefde overgeleverd; dit is niet enkel de indruk des lezers, doch wordt ook uitdrukkelijk geconstateerd. Zeus, verliefd op Europa,

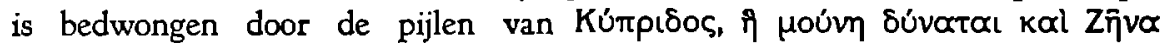

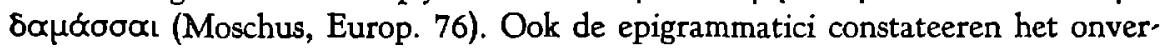
holen : zoowel Zeus als Hades als Poseidon zijn aan de liefdesgoden onderworpen

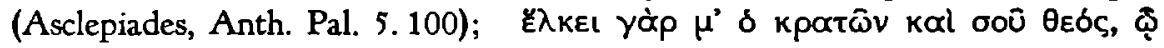

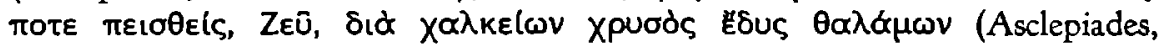

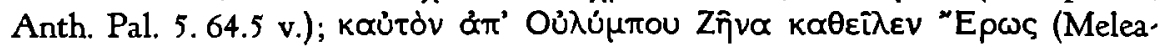
ger, Anth. Pal. 12. 101. 6). Daarom tart de kleine Eros den grooten Zeus, in het bewrustzijn van zijn overmacht (Moschus, Anth. Plan. 4. 200 ; vgl. Anth. Plan. 9. 108). „Dans son ensemble, la poésie de l'âge hellénistique justifie, illustre, pour ainsi dire, d'un commentaire perpétuel l'invocation fameuse placée par Euripide au début d'une de ses tirades "Eros, roi souverain des hommes et des dieux"." (Leg rand p. 65 v.). Volgens Lactantius (Inst. Div. 1.11.1/2) ontwierp een dichter het beeld van een triumpheerenden Cupido, voor wiens wagen Juppiter en de overige goden geketend uit liepen; Erwin R o h de (p. 108 no. 1) oppert de veronderstelling, dat een alexandrijnsch dichter hiervoor aansprakelijk is. In elk geval geeft het beeld de alexandrijnsche opvattingen treffend weer. 


\section{Moderniseering.}

Even opvallend als de vermenschelijking is in de alexandrijnsche poezie de moderniseering. Een sterk staal hiervan levert Callimachus' toonaangevend epyllion Hecale, waarin, op den Brilettus nabij Athene, ten tijde van Theseus, de vogels spreken over het morgenlijk lawaai der groote steden (fr. $64 \mathrm{~K}$; , V o n W i l a mo w it $z$, Hek. p. $35 \mathrm{v}$.), waarmede men vergelijke de steedsche details in de Argonautica, waar Apollonius ochtend en nacht beschrijft (4.1170/4; 3 . 744/50). Zooals reeds werd opgemerkt, poneerde $R$. R e it z e n st e in de stelling, dat Catullus in zijn epyllion een ruim gebruik heeft gemaakt van een alexandrijnsch voorbeeld, en wel op grond van een vergelijking tusschen Catullus' schildering van Peleus' bruiloft en een verslag door Callixenus (bij Athenaeus, 5. 196d) van een feest door Ptolemaeus Philadelphus. De dichters deinzen niet terug voor anachronismen; $\mathrm{V}$ on $\mathrm{Ch}$ rist-S chmid p. 146 wijst op de toiletkunsten van Medea (Ap. Rhod. 3.828 vv.). Wat van de alexandrijnsche epiek in het algemeen geldt, geldt stellig ook van de eigenlijke godenschildering. Ondubbelzinnige voorbeelden van moderniseering in de eigenlijke godenschildering te geven is echter, wegens de schaarschte onzer bronnen, nauwelijks mogelijk. Tot voorbeeld kan wellicht strekken het heilige woud van Demeter in Callimachus' zesde hymne ( $25 \mathrm{vv}$.): daar is namelijk niet sprake van de natuur van het oerbosch, doch van de cultuur van het park, en wel, zooals V on Wil a m owitz (H. D. II p. 30) opmerkt, van een park in alexandrijnschen stijl, gedeeltelijk met vruchtbomen beplant en door kanalen bewaterd; eigenlijk is alleen de groote popel heilig. Een ander voorbeeld is de conversatie tusschen de godinnen Hera, Athena en Aphrodite in het begin van Apollonius' derde boek : door haar delicaat en diplomatiek karakter frappeerde ze verschillende critici zoo, dat zij an het hof van Alexandrië dachten (Couat p. 306 ; Ma haff y p. 273 v.; De la Ville de Mirmont, M. D. p. 383/4; Mooney p. 34; Susemihl p.388; $\mathrm{C}$ ro iset p. 234). Al ontbreken ondubbelzinnige criteria, de indruk is daarom niet minder sterk. En dit brengt ons tot een laatste opmerking : de onderscheiding tusschen vermenschelijking en moderniseering is niet geheel gegrond en slechts overzichtelijkheidshalve gerechtvaardigd. Het is niet zoo, dat de dichters nu eens het principe der vermenschelijking toepassen, dan weer dat der moderniseering: zij schilderen de goden, zooals hun andere personnages, als menschen van hun eigen tijd en ongeving, met een sterke voorkeur voor het kleinburgerlijk alledaagsche; wij hebben dus ook in de gevallen van vermenschelijking te doen met moderne schildering, waarin echter ondubbelzinnige criteria van moderniteit ontbreken. De grenslijn is niet scherp te trekken. Onder "vermenschelijking" hebben wij gewezen op de burgerlijke sfeer, die voor de mime kenmerkend is, in de schildering van Aphrodite aan haar toilettafel en van haar klachten over den eigengereiden lummel : wij mogen hier evenzeer van moderniseering spreken, daar de sfeer der mime niet enkel kleinburgerlijk is, doch ook modern in haar kleinburgerlijkheid.

Spel met de dupliciteit.

Het derde moment is het spel met de dupliciteit van eponyme godheden. Ook 
hier speelt ons de schaarschte onzer bronnen parten; directe bewijzen zijn nauwelijks te leveren, en vele vragen moeten onbeantwoord blijven.

Bij Ovidius treffen wij verschillende allegorische figuren, waarvan een uitvoerige schildering gegeven wordt; het zijn vrije, poetische figuren, los van de traditioneele legendes, waaraan 's dichters vindingrijkheid haar hart kan ophalen. Mogelijk heeft hij soortgelijke voorbeelden bij de alexandrijnsche dichter gevonden, en zeker is, dat, als van dergelijke allegorische figuren, die bij Nonnus in grooten getale en met overvloedige details voorkomen, een tiende deel op alexandrijnsche schrijvers mocht teruggaan, zij bij dezen uitstekend vertegenwoordigd waren. Ook de schilderkunst geeft een vingeraanwijzing : Apelles ontwerpt een uitvoerig

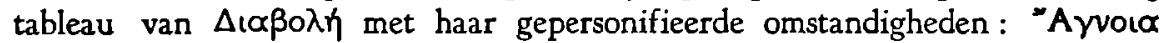

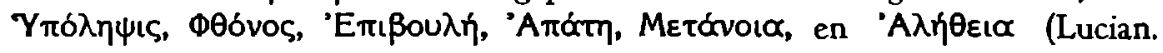
Calumn. non tem. cred. 4 ; Overbeck No. 1874). De esprit, die in Ovidius' schilderingen opvallend is, ontbrak ook bij den schilder niet, getuige Stob. Floril. CV 60 (Overbeck No. 1868): 'A

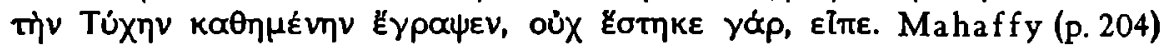
wijst ook op de optochten en maskerades; in een optocht te Alexandrië werden Jaar en de vier Seizoenen uitgebeeld.

Deze vrije, poetische, los van de mythologische traditie staande, allegorische figuren zijn echter niet de merkwaardigste verschijningen. Veel belangrijker is, dat een soortgelijke behandeling, vrij van de traditie, ook ten deel viel aan figuren, die niet los staan van de mythologie, en in den loop der tijden een eigen physiognomie verkregen hebben, een soort demythologiseering en personifieerende herijking. Ook hier kunnen wij geen bewijzen leveren, tenzij indirecte, en dus problematische. Mag men Kna a ck (p. 25) gelooven, dan gaat de schildering van Sol's (of liever : Zon's) hofhouding in Ovidius' "Phaethon” op een alexan' drijnschen dichter terug; Ovidius nu (zie onder „Phaethon”) schildert niet den Helios der traditie, doch een figuratie van de Zon, waarbij in alle details de werkzaamheid van het zonnelichaam gesymboliseerd wordt. Dezelfde dichter ontwerpt een uitvoerig tableau van de behuizing van Somnus in "Ceyx et Alcyone" (zie daar), misschien, als men $\mathrm{E} \mathrm{h}$ wald in zijn commentaar gelooven mag, naar een alexandrijnschen voorganger : ook hier is elk detail afgestemd op het begrip Slaap, en geen wonder dus, dat Slaap uitermate slaperig is in zijn slaperige omgeving. Ovidius, of zijn voorganger, of beiden, ignoreeren hier den Hypnus van Homerus, die, allesbehalve dodderig, een uitgeslapen rakker is, toevend op het weinig slaperige Lemnos. Ovidius, in de Amores (zie onder „Erysichthon”) speelt, mogelijk naar alexandrijnsche voorbeelden, ook met Ceres als het Inbegrip van de vruchtbaarheid. Wellicht ook was, in de schilderkunst, Boreas geschilderd in dien trant, dat de domestica ira van deze wind alles overheerschte (zie onder „Boreas”).

Wat echter het meest kenmerkende is, is de vreemde vermenging van het zakelijke en het persoonlijke element in deze godheden, beide elementen tot in de uiterste consequenties ontwikkeld. Boomnymphen zijn ten nauwste verbonden met haar boomen, zoo laat Callimachus zich door de Muze zelf verzekeren. Daarom wordt de nymph Melie aủंóx $\theta \omega v$ genoemd. En toch (of beter : juist 
daarom) geeft de dichter ons sterk menschelijke details van haar angst, als haar boom in gevaar is : bleeke wangen, hortende ademhaling (Deloshymne 79 vv.). In een verband, waar wij wel degelijk aan de boomen moeten denken, horen wij van het fladderend haar van den Helicon (81 v.). In de Homerische Apollohymne wordt het geographische en het persoonlijke moment, streng gescheiden, achter elkaar en niet door elkaar behandeld ( $\mathrm{T}$ h o m a n n $34 \mathrm{v}$.); in Callimachus' Deloshymne is dit niet het geval: Peneus-god en Peneus-rivier zijn identiek en een en dezelfde; hij plengt tranen om Leto's ellendigen toestand (121), doch vluchtende (persoonlijk) wentelt hij voort (zakelijk) door het Tempedal (105). Het meest frappante geval is de schildering van Ismenus, den riviergod : zijn dochters Dirce en Strophie houden hun vader aan de hand (zeer persoonlijk), doch deze wordt in één adem zwartkiezelig genoemd (zeer zakelijk; 76 v.). De dichter wil geen verzoening tusschen de beide elementen in deze eponyme godheden, doch speelt met de ongerijmdheid van deze voorstellingen in een flikkerend contrast tusschen beiden. En dit is niet enkel het geval met nymphen en riviergoden, doch ook met groote figuren uit de traditioneele mythologie als Helios en Demeter. Het zakelijk moment in hen wordt kunstmatig en moedwillig tot herleving gebracht, doch daarnaast wijkt het persoonlijke geen duim; ja, beide momenten worden met elkaar vermengd. Zoo kan het geschieden, dat het lengen der dagen te wijten is aan verliefd (Helios) verwijlen van helios (zie onder "Leucothoe"), dat de oudersmart van Eos zich in atmospherische verschijnselen openbaart (zie onder „Aurora”), dat Demeter, zeer menschelijk verliefd op Iasion, naast minnares niet minder het begrip der vruchtbaarheid blijft (zie onder „Erysichthon”). Op dit spel met de personificaties, op het spel met de dupliciteit der eponyme godheden hebben Bethe (G. D. 309) en Thomann (p. 34 v.) gewezen.

\section{Humorenironie.}

Tenslotte moeten wij spreken over de humor en ironie, waarvan de alexandrijnsche godenschildering doortrokken is. Hoe onmiskenbaar aanwezig, vaak zijn zij moeilijk te definieeren. $Z_{i j}$ zijn het parfum van de alexandrijnsche godenschildering. Soms liggen zij als een zachte glans over de verzen, zooals in de schildering van de kleine Artemis op vader's knie; Körte (p. 108) herinnert aan den Zeus van Raphael, die Ganymedes in de wang knijpt. Wat tastbaarder is de ironie in de schildering van Aphrodite's ijdelheid en coquetterie ( $\mathrm{Cou}$ a t p. 112 v.; Huber p. 53 ; Von $\mathrm{Christ-Schmid} \mathrm{p.} \mathrm{137:} \mathrm{in} \mathrm{altuäterlicher}$ Feierlichkeit und doch nicht ohne Schelmerei), of van zwartkiezeligen Ismenus en van 'Aowtòs ßapúyouvos, die de anderen niet bij kan houden (Deloshymne 76 vv.; Bethe p. 309). Elders verhoogen pathetiek en schijnbare naieviteit de ironie der situatie en der voorstelling van zaken : men leze bijv. het gesprek tusschen Leto en Peneus, waarin onder meer de godin den vluchtende vraagt,

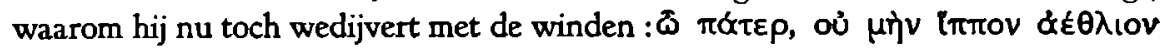
$\alpha \mu \phi \iota \beta \varepsilon \hat{\beta} \eta \kappa \alpha \varsigma$ (Deloshymne 113). Vele tafereelen uit de Artemis- en de Deloshymnen veroorloven zich weinig minder dan de oude comedie (Körte p. 106 vv.): Hermes boeman, Iris' nerveuze dienstbejag (met de vergelijking van den 
jachthond!), en vooral de schildering van Heracles' vraatzucht, hoe hij smachtend aan de poort Artemis verbeidt en haar vetten buit, en de godin opwekt, ook ossen en ander ,schadelijk" gedierte te verdelgen (Cou a t p. 271). Het behoeft geen betoog, dat in al deze gevallen van naieviteit geen sprake is : de dichter wil het contrast tusschen de goddelijke verhevenheid en de kleinmenschelijkheid. Hij wijst er trouwens zelf op en lokt het contrast uit. De Cyclopen zijn bezig aan een groot werk, zegt Callimachus ergens, onze verwachtingen spannend; doch het is het bekende geval van de barende bergen : het groote werk blijkt te zijn, een paardetrog (Herter p. 80 v.). Soms ook herinneren de kleinmenschelijke tafereelen aan grootsche Homerische scenes, hetgeen tot het contrast tusschen het eigenlijk goddelijke en het feitelijk menschelijke bijdraagt. Onder dit gezichtspunt heeft Herter de Artemishymne onderzocht. De scene, waarin baby Artemis op vader's knie smeekend de armpjes uitstrekt naar zijn baard, herinnert aan en contrasteert tegelijk met de bekende scene uit de Ilias, waar Thetis voor haar zoon bij Zeus intervenieert (Herter p. 71; V on Allmen p. 34). Een soortgelijk contrast zoekt misschien ook Apollonius Rhodius, waar hij omstandig beschrijft, hoe Eros zich wapent en den boog spant (3.156 v., 278 vv.): uitvoerig beschrijft zoo Homerus de voorbereidingen tot het fatale schot van Pandarus in Ilias IV (105 vv.); doch welk een contrast tusschen de twee schutters! (zie onder „Raptus Proserpinae"). Vooral echter in de liefdesavonturen der goden valt het contrast tusschen goddelijke hoogheid en menschelijke kleinheid op. De apostrophes, onder vermenschelijking geciteerd, spreken boekdeelen. Men mag veilig aannemen, dat de alexandrijnsche dichters het non bene conveniunt nec in una sede morantur maiestas et amor in de verliefde gedragingen der goden, in hun vaak penibele vermommingen vooral, duidelijk hebben laten uitkomen, zoo niet hebben uitgesproken. Ironie spreekt uit het alexandrijnsch motief van de verwaarlozing der cultusplaatsen door de verliefde goden. Ook leggen deze dichters niet zooveel voorliefde voor de naijverige Hera aan den dag om de gedragingen van haar en haar gemaal stichtelijker te maken. Wanneer Zeus zucht over de jaloerschheid van Hera, „so rechnete" Callimachus wel „auf beifälliges Lachen (beter : op een ironische glimlach) bei seinen Lesern" (V o n Allmen p. 34). De rol, die Hera bij Apollonius Rhodius in de affaire met Thetis haar gemaal toedeelt, is belachelijk en smadelijk; in de episode van Sinope is Zeus' gedrag grotesk (De la Ville de Mirmont, M. D. p.169). Het grootste contrast echter vindt men in Eros, den kwajongen, het bikkelende ventje, dat met een mooien speelbal gepaaid moet worden en dat zich vastklampt aan moeders rok (Ap. Rh. 3.132 vv., 146 v.), doch dat tevens is de tyran van goden zoowel als menschen (Cou at p. 152 v.). Herter (p. 94) spreekt van een beminnelijken humor, even ver van spot als van ernst verwijderd; $\mathrm{Huber}$ (p.69) ontkent, dat er in de godenschildering van parodie of burleske sprake zou zijn. Dit laatste is onjuist; beslissend is echter de vraag, wat er het doel van is. Van iconoclasme is geen sprake, doch ook niet van eenigen afstand tusschen goden en menschen. Het is de moedwil en het spel van den verlichten, fijnbesnaarden blasé.

$\mathrm{Na}$ de alexandrijnsche godenschildering vraagt die der neoterici onze 
aandacht. Onze bronnen zijn uiterst schaarsch; wij bezitten slechts Catullus' epyllion. Misschien zouden Calvus' Io, Cato's Diana, Cornificius' Glaucus en andere werken, indien zij behouden waren, ons meer geleerd hebben. Catullus' epyllion behoort tot die lyrische epiek, waarin beschrijvingen en lyrische expressie van gevoelens het eigenlijke relaas der gebeurtenissen verdrongen hebben (J a ckson p. 41); het is de laat-alexandrijnsche stijl (Heinze p. 99 vv.). Met het lyrisch element gaat een groote plechtstatigheid gepaard, waarbij de zwaarvalligheid der versificatie goed aansluit. Catullus treedt op als een vates, en bespiegelt over de verwording der zeden, doch hij doet dit naar Callimacheissche maatstaven overdreven, zonder de correctie der ironie : het is geen spel meer. Over de moderniseering in Catullus is reeds gesproken in $\S 3$ : hij past dit principe niet zelfstandig toe, doch copieert de middelen zijner voorgangers. Het ligt in de lijn der verwachting, dat dit ook bij de andere principes het geval is. Er zijn gevallen aan te wijzen van vermenschelijking en humor, doch bijzonder gelukt zijn zij niet. Catullus vermeldt, dat ter bruiloft ook verschijnt pater divom sancta cum coniuge natisque (298): "Juppiter met familie", zooals Ri e se opmerkt, aangehaald door $L$ a f a ye (Cat., p. 165), die van een braven vader spreekt en eerbare ontspanning. Verder is er de realistische schildering der oude besjes aan haar spinnewiel, der Parcen, waarin Kroll (ad 316) iets ontroerends-comisch ziet (vergelijk ook $\mathrm{L}$ a f a ye, Cat. p. 169 en R. R e it z e nste in p. 89 n. 1), waarin echter het realisme door de worstelende woordkunst niet tot zijn recht komt. Ook in de schildering van den "ietwat onbehouwen" Centaur ( $\mathrm{K}$ roll ad 283) met zijn bloemenkransen, kunstloos gevlochten, komt de ironie niet wel uit de verf; wij missen de Ovidiaansche urbaniteit. Ook in de schildering der verwonderde Nereiden gaat het menschelijke ten onder in de zwaarvalligheid der verzen en het streven naar een plastisch effect. Catullus zwoegt, doch huppelt niet. Wat het spel met de dupliciteit betreft : Catullus vermeldt wel, dat Penios het Tempedal verlaat, doch het ongerijmde van zulk een naieve voorstelling schemert niet door; aan de vermelding der reidansende nymphen ontbreekt alle zwier. Ondanks het feit, dat wij slechts luttele honderden verzen tot onze beschikking hebben, merken wij bij den neotericus wel een streven naar vermenschelijking, moderniseering en ironie, al heeft de dichter met zijn pogingen weinig succes. De bewijskracht ervan is des te grooter, omdat plechtstatigheid in dit werkje den toon aangeeft. De neoterici hadden nog te veel met formeele moeilijkheden te kampen, en verder kozen zij de pompeuze, laat-alexandrijnsche manier. Hun werk geeft daardoor slechts grooter relief aan Ovidius' prestatie, zijn soepelheid en zijn zelfstandigheid.

Aangezien Vergilius tot den strengen ouden stijl terugkeerde der Grieken (Homerus) en Romeinen (Ennius) en de alexandrijnsche verworvenheden slechts als middelen en niet als doel beschouwde, behoeven wij op zijn godenschildering hier niet nader in te gaan : hij behoort niet tot de moderne, de alexandrijnsche richting. In de bespreking der verhalen zullen wij verschillende malen gelegenheid hebben op de verschillen te wijzen tusschen hem en Ovidius. 


\section{§ 5: VERANTWOORDING DER METHODE}

Elke indeeling, wil zij verantwoord zijn, moet uit den eigen aard van het onderwerp voortspruiten en aan de eischen der doelmatigheid voldoen. In onze studie over de godenschildering in de Metamorphosen komt slechts één indeeling in aanmerking, de indeeling naar de hoofdmomenten vermenschelijking, moderniseering, het spel met de dupliciteit der eponyme godheden en humor en ironie. Hierbij kan men twee wegen bewandelen: men kan uitgaan van de hoofdmomenten, en van elk hoofdmoment achtereenvolgens alle gevallen registreeren in elk der verhalen; men kan ook uitgaan van de afzonderlijke verhalen, en in elk afzonderlijk verhaal alle gevallen registreeren van elk der hoofdmomenten. Nochtans is deze indeeling naar de hoofdmomenten in de bespreking in geen harer beide vormen gevolgd. Wij bespreken de afzonderlijke verhalen, zonder hierin volgens een ijzeren schema achtereenvolgens van elk hoofdmoment elk geval te registreeren; eerst in de conclusie, waar gebruik gemaakt kan worden van de verkregen resultaten, wordt een systematisch overzicht gegeven naar de afzonderlijke hoofdmomenten. Dat in de bespreking der afzonderlijke verhalen geen ijzeren schema naar de hoofdmomenten gevolgd wordt, geschiedt op grond van de volgende overwegingen. Zulk een behandeling bevordert niet de overzichtelijkheid, en het eenige, dat er wel bij zou varen, is de omvang van den text, die eenige malen grooter zou zijn dan hij thans is. De hoofdmomenten zijn in de practijk niet scherp te scheiden : zij spelen door elkaar, op elkaar inwerkend. Elk geval van elk der hoofdmomenten moet in zijn geheele omgeving beoordeeld worden, omdat het eerst in zijn omgeving tot zijn recht komt. Wil men het tot zijn recht laten komen, dan dient daarbij elke nevenfactor tot zijn recht te komen. Een bespreking, strikt naar de gescheiden hoofdmomenten, zou dus in feite neerkomen, niet op een overzichtelijke scheiding der stof, doch op een meervoudige herhaling van dezelfde materie, telkens onder een ander gezichts. punt belicht; zij zou dus niet aan de eischen der doelmatigheid voldoen. De bespreking moet zich daarom in elk afzonderlijk verhaal aanpassen aan de bijzondere omstandigheden van dat verhaal. Ideaal zouden de omstandigheden zijn, indien wij een reeks verhalen te bespreken hadden, uitvoerig en regelmatig ontwikkeld, waarin de goden steeds de hoofdrol vervulden, waarin de hoofdmomenten gemakkelijk aantoonbaar waren, terwijl ons de versies van Ovidius' voorgangers bekend waren tot in details. In feite echter zien wij ons nu eens geplaatst tegenover een uitvoerig verhaal, dan weer een snelle schets, een enkele episode of zelfs een enkele opmerking. Ook spelen de goden niet steeds een hoofdrol, doch verschijnen zij soms slechts een oogenblik op het tooneel. Vaak is het moeilijk de hoofdmomenten strikt te bewijzen; in vele gevallen geldt het, een - onmiskenbare, doch weinig tastbare - sfeer voelbaar te maken. Met name geldt dit van de ironie. De annwezigheid ervan zonder meer te constateeren heeft weinig zin, daar hiermede niemand gebaat is, noch de lezer, die er gevoelig, noch de lezer, die er ongevoelig voor is. Soms bewijzen analoge passages bij denzelfden of bij een anderen dichter goede diensten; vaak echter kan men enkel trachten den lezer in de vereischte stemming te brengen door een geslaagde 
paraphrase of commentaar; een schijnbaar gemakkelijke, doch in feite uiterst moeilijke en gevaarlijke opgave, daar men zich overal bedreigd ziet door teugelloosheid en geaffecteerdheid, fouten, die men eerder in een ander dan in zichzelven ontdekt, het moeilijkst in de hitte van den strijd. Nu zouden vaagheid en willekeur vrij gemakkelijk te vermijden zijn, indien wij steeds Ovidius' voor. beelden bezaten. Het bezit van Ovidius' voorbeelden is van onschatbaar belang, en omdat een vergelijking van overeenkomsten en verschillen tusschen de versies een helder licht pleegt te werpen op de wijzigingen en de bedoelingen ervan, en omdat hieruit de mate van afhankelijkheid en onafhankelijkheid van Ovidius kan blijken. $\mathrm{Nu} z$ zijn wij soms zoo gelukkig Ovidius' voorbeeld te bezitten. Helaas echter is dit in al te veel verhalen niet het geval, en dit is des te meer te betreuren, daar het meestal die verhalen zijn, die op alexandrijnsche dichters teruggaan. Weliswaar kennen wij in enkele gevallen de versie van zijn voorganger in groote lijnen, zoodat wij althans eenig houvast hebben voor een vergelijking, doch het komt in onze studie vooral aan op de kleine details, op een enkel woord, een enkele zinswending, op den toon, die de muziek maakt, en het is juist hierin, dat onze inlichtingen ons deerlijk in den steek laten. Talrijk zijn de pogingen, die in de laatste eeuw ondernomen zijn om verloren gegane alexandrijnsche versies in groote lijnen en zelfs tot in details te reconstrueeren. De waarde van deze reconstructies is uiterst twijfelachtig, en dat zelfs zeer plausibele gissingen vergissingen kunnen zijn, hebben de harde feiten geleerd. Recente vondsten hebben bijvoorbeeld bewezen, dat de scherpzinnigste interpretaties van fragmenten met betrekking tot Callimachus' Hecale en zijn verhaal van Acontius en Cydippe volkomen bezijden de waarheid waren (D ietzler p. 28). Daarbij komt, dat niet weinig critici te werk gingen met een verbijsterende willekeur en simpliciteit, en speciaal een slecht begrip verrieden van Ovidius' dichterschap en werkwijze. Terwijl zij op vaak apodictische wijze vergelijkingen met duizend onbekenden oplosten met behulp van anderhalf gegeven, verwaarloosden zij merkwaardigerwijs de gelegenheid om zich een gefundeerd oordeel te vormen over Ovidius' houding ten opzichte van zijn voorgangers daar, waar wij zijn voorbeeld wel bezitten (bijv. Homerus of Vergilius). De uiterste behoedzaamheid is daarom geboden in dergelijke exploraties, inzonderheid daar, waar in het schemerdonker van enkele gegevens de lokroep der Sirene klinkt. Wij hebben ons daarom, hoe noode ook de versies missend van Ovidius' voorgangers, in het algemeen onthouden van benutting van problematische reconstructies, en daar, waar wij meenden een stap te mogen doen, deden wij het onder voorbehoud. De geschiedenis van de studie van Ovidius' bronnen, en de studie zelf van de bronnen (het materiaal is deels niet juist behandeld, deels nog niet uitgeput) kunnen voorlopig rusten. In het wespennest van polemieken den lezer binnen te leiden, daartoe zagen wij doorgaans geen reden, vooral daar dit meestentijds niets zou hebben bijgedragen tot een beter verstaan van Ovidius' godenschildering, het doel dezer studie, en slechts den omvang van den text zou hebben vergroot. 


\section{BESPREKING DER VERHALEN}

\section{CONCILIUM DEORUM (I 163-252)}

Na de cosmogonie, de beschrijving der vier tijdperken der menschheid en een kort bericht over den Gigantenkamp beginnen de eigenlijke verhalen met een godenraad, welke de inleiding vormt op den zondvloed en waarin het verhaal van Lycaon verweven is. Deze godenraad is door Ovidius zelf verzonnen; hij neemt deze gelegenheid bij den aanvang der vertellingen te baat om ons in te lichten over de godenwereld, die in het vervolg van de Metamorphosen zulk een belangrijke plaats inneemt. Hij begint daarom met een uitvoerige beschrijving van zijn Olympus, van Godenstad. Deze is naar Rome's beeld en gelijkenis geschapen. Romeinsch is de standenindeeling: aan het hoofd de rijksregent; vervolgens zijn er de patriciërs, de nobiles (172), de potentes Caelicolae clarique (173 v.); tenslotte is er nog de plebs (173). Naar Rome ook wordt het stadsbeeld beheerscht door het verheven paleis, omgeven door patriciërshuizen, terwijl de lagere standen in meer verwijderde wijken wonen. Ook voor de politieke toestanden is Rome het voorbeeld. De raad wordt bijeengeroepen in een marmeren zaal van het koninklijk paleis, zooals te Rome de senaat bij tijd en wijle vergaderde op den Palatijn. Juppiter komt met een formeel voorstel, in herinnering aan Rome sententia genoemd (243) en „zooals in den Romeinschen senaat sommigen hun stem motiveeren, anderen zich zonder meer bij het voorstel aansluiten, zoo ook de goden : partes adsensibus inplent komt overeen met het officieele verbo adsentiunt" (Ehwald ad 244). Corpus wordt tweemaal in juridischen zin gebruikt $(186 ; 190)$.

Dat Ovidius den Olympus grondig romaniseert, is geen punt van debat; de meeningen lopen echter uiteen over 's dichters bedoelingen. $R$ and (p. 59) wordt getroffen door de speelsche noot erin, en tracht den indruk, dien deze Godenstad op Ovidius' tijdgenooten moet hebben gemaakt, voelbaar te maken door Ovidius' moderniseering opnieuw te modemiseeren: „We are introduced to a thoroughly Augustan heaven, where plebeian deities occupy the less desirable quarters and the upper classes reside in what the poet calls the Palatine of the Sky, with the Milky Way, the celestial Fifth Avenue, or "Watlinge strete", leading up to their mansions." Heinze (p. 11) meent, dat deze romaniseering niet bedoeld is als parodie, doch dat Ovidius den Olympus meent te eeren door hem op den Palatijn te laten gelijken. Parodie is een bedriegelijk woord, doch stellig mogen wij deze schildering speelsch noemen. Wie kan een glimlach onderdrukken, wanneer hij leest van het clientenstelsel op den Olympus met de 
salutatio matutina (atria nobilium valvis celebrantur apertis, 172)? Ook is het moeilijk aan te nemen, dat de dichter eershalve zegt, dat de goden daar posuere penates (174), een staande uitdrukking, die, van de goden gebruikt, niet zonder humor is. Ook het idee van een plebs onder de goden is vermakelijk. In de Ibis specificeert Ovidius deze plebeii: vos quoque, plebs superum, fauni satyrique laresque Fluminaque et nymphae semideumque genus (81 v.). Deze nu plegen niet op den Olympus te wonen. Juppiter zegt zelf verderop van deze mindere goden (sunt mihi semidei, sunt rustica numina, nymphae Faunique satyrique et monticolae silvani, 192 v.), dat zij hun woonplaats op de aarde hebben (195). Deze inconsistentie deert den dichter niet; het amusante idee van een volledige gelijkschakeling van Rome en Olympus gaat voor, en het moet gezegd, dat het idee zoo aardig is, dat de critiek gaarne zwijgt.

Leerzaam is een vergelijking van den Ovidiaanschen Olympus met den Vergiliaanschen : het contrast is volkomen. Vergilius in zijn schildering van den Olympus in Aeneis X, bij den eenigen godenraad, die bij hem voorkomt, is in zijn details uiterst gereserveerd en ontmenschelijkt hem zooveel doenlijk. De details, die hij aan het eind geeft, hebben niet ten doel een plastische beschrijving te geven van de zeden in den hemel, doch de majesteit aanschouwelijk te maken van den hoeder der fata (116 v.). Wat wij van Juppiter's paleis vernemen, is nauwelijks meer dan een poetische omschrijving van den aether (1 vv.). Vergilius spreekt gemeenlijk over den hemel "meer wetenschappelijk dan poetisch" (He inze V.E. T. p. 317). Kenmerkend voor Vergilius en Ovidius is, dat de eerste van aethere summo spreekt (1.223; Olympus = aether : 12,140 en 791, vgl. 11. 867), de tweede van summa arce (1. 163 ; arx imperii : E h w ald ad 176; $a r x=$ Olympus : Fast. 5.34 en 41). Ovidius is kwistig met details, en trekt niet alleen een verregaande parallel met Rome, doch aarzelt ook niet, Rome uitdrukkelijk te vermelden: hic locus est, quem, si verbis audacia detur, Haud timeam magni dixisse Palatia caeli (175 v.). Er is dus wel degelijk van audacia sprake. $\mathrm{Nu}$ is echter het contrast met Vergilius niet enkel een feitelijk contrast, doch het lijkt ook welbewust en opzettelijk te zijn : hij neemt van dezen over conciliumque vocat (167: Verg. 10.2), herinnert dus aan hem, wat aan de verschillen nog meer relief geeft. Uitvoerig en aan het begin der eigenlijke vertellingen, mag deze schildering van Godenstad programmatisch genoemd worden : zij is een baken in zee ; zij leert ons, dat wij in de Metamorphosen met een zeer moderne godenwereld te doen hebben.

Volgens B a r th ol omé (p. 32) herinnert Ovidius in zijn schildering van den verbolgen Juppiter aan het cultusbeeld van Juppiter Tonans. Het is niet onmogelijk; men zou het gaarne gelooven. In elk geval introduceert Ovidius hier in de epiek de gelukkige omschrijving van Juppiter: Tonans. Dit woord herinnert

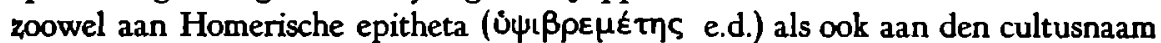
Juppiter Tonans, voor wien Augustus, op wondere wijze bij blikseminslag aan den dood ontsnapt, een eeredienst had ingesteld (de tempel werd 1 September 22 ingewijd ; Suet. Aug. 29. 9 ; W is sow a R. K. p. 122). Ovidius teekent Juppiter in een verbolgenheid, zooals deze naar zijn meening "Juppiter waardig" is (166). Hij maakt daarbij gebruik van de bekende Homerische verzen over den hoofdknik 
van Zeus (I $528 \mathrm{vv}$ ), maar ofschoon zijn verzen van driftige energie geturgen, is de verheven majesteit van den Homenschen Zeus geweken : het goddelijk fiat is geworden tot een uiting van verbolgenheld, en de god, die terque quaterque zijn manen schudt als een brieschende leeuw, is wel vreeswekkend (terrificam, 179), doch gedraagt zich onbeheerschter dan wij van de koninklijke majesteit verwachten : hyj is al te zeer de potentaat Er schuilt hierin een zeker element van vermenschelijking (Am 3132 vertelt Ovidius, dat Tragoedia densum caesane terque quaterque caput schudde, Tragoedia wordt als violenta en animosa, 11 en 35, getypeerd) Het verloop van de vergadenng bevestigt dezen indruk. Juppiter is daarin met de zeer hooge rex ommibus idem van Vergilius, doch een demagoog, die zijn volgelingen opzweept tot foev- en bravo-geroep, doortrapt in de rhetonek Weliswaar laat Juppiter aan de vergadenng de eer en spreekt van „wi”" (194 v), doch in feite is de rad slechts auditonum en klankbord. Het is, alsof wij Hitler hooren fulmineeren tegen de democratie in het algemeen, om plots het eigenlyke thema aan de orde te stellen (,Ich rede von der Tschechoslowake1"), als Juppiter herinnert aan den hachelijken Gigantenstrijd en verklaart, dat de toestand thans nog erger is, dat een ver strekkende beslissing genomen, het menschelijk geslacht verdelgd, de rotte plek uitgesneden moet worden, om dan uit te roepen :

an satrs, o supen, tutos fore creditis illos, 196 cum mihr, qui fulmen, qui vos habeoque regoque, struxent insidias notus fentate Lycaon? 1

Herop kan enkel foe1-geroep volgen, hetgeen dan ook geschiedt Het is bewuste rhetoriek, zooals uit het volgende blıkt Voce manuque (205) bedaart huj den storm van verontwaardiging, doch als de stilte weer is ingevallen, houdt hij deze nog even aan 'zoolets werkt beklemmend en spitst de aandacht (cf. brevz spatio silet et dubitare videtur Suspenditque animos, 7.307/8, Ulixes oculos paullum tellure moratos Sustulit ad proceres expectatoque resolvit Ora sono, 13 125/7) Op deze stilte nu, en het supeneure gebruk, dat de redenaar ervan maakt, wijst Ovidius, door ze tweemaal te vermelden, zonder zijn woorden noemenswaard te vaneeren, merkwaardig voor een dichter, die op snelhe1d van vertellen en elegantie van dictie bedacht is De bedoeling ervan is, dat de lezer ervan doordrongen rake, hoe supeneur de Donderaar de sttuatie beheerscht

De pretas der goden jegens Juppiter wordt vergeleken met de pretas jegens Augustus van zijn onderdanen Gebrukelık 1s, dat het kleinere met het grootere, den keizer met den oppergod vergeleken wordt; doch hier is de rangorde omgekeerd en wordt de oppergod (de hemelsche Augustus) met den ke1zer (den aardschen Juppiter) vergeleken Het is een aardig idee, doch het is Ovidius' bedoeling nuet te spotten De verklanng van deze passage is wel, dat Ovidius aldus op ingenieuze wizze voldoet aan de ongeschreven, doch onmiskenbare wet, dat de kunstenaar aan het begin van een groot werk den kelzer heeft te eeren; reden, waarom Augustus geapostropheerd wordt De geheele romaniseering van Godenstad te verklaren als een hulde aan den ke1zer is echter een te eenzijdige interpretatie. 
Het besluit tot verdelging van het menschelijk geslacht wordt genomen, en daarom haast de dichter zich naar de uitvoering ervan. De dichter vertelt echter toch nog van eenige reactie der goden, en deze reactie is voor de goden typeerend. Wat hen verontrust, is hun wierook, wie zal hun nog wierook offeren? De kwestie is futiel, doch voor de goden van groot belang. De turba ambitiosa (Fast. 5. 298) is meer dan gesteld op haar wierook, haar ambitiosus honor, zooals uit andere passages blijkt (zie onder "Calydonius aper”). De dichter glimlacht om deze menschelijke zwakheid der hemelingen.

De ouverture der eigenlijke vertellingen wordt dus gekenmerkt door moderniseering en vermenschelijking, niet zonder een glimlach en eenige ironie. De godenschildering is alexandrijnsch, en dat niet toevallig, doch programmatisch.

\section{DILUVIUM (I 262-342)}

Voor den zondvloed worden alle beschikbare krachten te land, ter zee en in de lucht ingezet. In de lucht worden Aquilo en de andere wolkenverjagende winden verdreven, aan den regenbrenger Notus wordt vrij spel gegeven, Iris in haar kwaliteit van regenboog voedt de wolken. Daarnaast mobiliseert Neptunus de krachten van het water, de rivieren der aarde en de golven der zee. Als het doel der strafexpeditie bereikt is, wordt eerst weer de hemel geklaard, door Aquilo, en worden verder de wateren der aarde teruggetrokken op hun basis. In het kader van deze fantasie, speelsch in haar systematiek (zooals trouwens heel de zondvloed bij Ovidius een pittoresque geval is), waarin men iets van den Romeinschen organisatiezin bespeurt, komt de moderne inkleeding van Neptunus' actie goed tot haar recht. Neptunus levert voor de strafexpeditie auxiliares (iuvat auxiliaribus undis, 275). Zij vormen, zooals de hulptroepen in de Romeinsche legers voor een belangrijk deel, de ruiterij, want niet zonder reden spreekt de dichter tot driemaal toe van teugels (totas inmittite habenas, 280 ; ora relaxant, 281 ; defrenato cursu, 282). Neptunus richt tot zijn manschappen een korte cohortatio (non est hortamine longo Nunc' ait 'utendum, 277 v.). Verder is Triton Neptunus' signalenblazer. Uitvoerig wordt geschilderd, hoe hij zijn eigenaardigen hoorn aan de lippen zet $(333 \mathrm{vv}$.) : het is een belangrijk moment, de aanval gaat beginnen. Tot tweemal toe wordt vermeld, dat het teeken tot den terugtocht gegeven wordt (signo Iam revocare dato, 334 v.; cecinit iussos inflata receptus, 340 : poetische verwerking van receptui canere). De dichter legt er den nadruk op, dat de golven, welgedisciplineerd, onmiddellijk aan het signaal gehoor geven. Systematische romaniseering dus, te vermakelijker, waar het de eigenlijk zoo ongebreidelde elementen betreft. Het behoeft geen betoog, dat de gansche inkleeding Ovidius' eigendom is.

Het is merkwaardig, dat Neptunus, ofschoon hij optreedt als de heerscher der wateren en tyrannus (276) en rector pelagi (331) genoemd wordt, toch geintroduceerd wordt als caeruleus frater (275): de broeder komt den broeder te hulp. Misschien moet er hier niet veel gewicht aan gehecht worden, doch uit talrijke andere passages blijkt, dat Ovidius bij voorkeur met de familierelaties der goden opereert. Caeruleus wordt Neptunus genoemd : zooals aan alle god. 
heden van wateren wordt hem de donkerblauwe kleur van zijn element gegeven, merkt $\mathrm{E} h \mathrm{~h}$ a l d terecht op. Het moment der dupliciteit is hier echter nauwelijks aanwezig ; in elk geval komen caeruleus en viridis herhaaldelijk voor bij de goden van wateren, zoodat er geen moment van verrassing in is gelegen. Moeten wij echter in caeruleus een vertaling zien van het bekende Homerische epitheton van Poseidon: kuowoxalims? Ehwald (ad 283) suggereert het, doch ten onrechte. Weliswaar worden de donkerblauwe of zeegroene haren van zeegoden verschillende malen vermeld (bijv. 2.12;13.960; Fast. 1. 375), doch uit andere passages blijkt, dat men niet alleen aan de haren moet denken : caerula bracchia heeft Glaucus (13.962), en, als Acis in een riviergod veranderd is, is hij toto caerulus ore (13.895). Caeruleus moet dus evenmin met kuorvoxaltm 9 gelijkgesteld

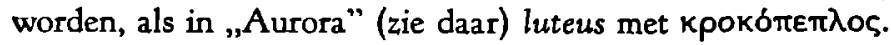

Het moment der dupliciteit van eponyme godheden komt in dit verhaal wel tot uiting in de schildering van Notus-god (264/9), waarin zeer plastisch (B a r tholomé p. 57) de madidus notus-wind vertolkt wordt, en treedt vooral in de activiteit van Iris aan het licht : het persoonlijke en het zakelijke spelen dooreen. Nuntia Iunonis wordt zij genoemd (270), zuiver persoonlijk; in haar veelkleurig kleed (varios induta colores, 270 ) is nog het zakelijke in het persoonlijke omgezet (zie ook onder "Ceyx et Alcyone"); daarnaast echter is zij de regenboog zonder meer, in welke hoedanigheid zij, vocht optrekkende (naar antieke opvatting; $E \mathrm{~h}$ wald ad 270 ), de wolken voedt.

Wij vinden dus in deze episode speelsche moderniseering en het spel met de dupliciteit van eponyme godheden.

\section{DAPHNE (I 452-567)}

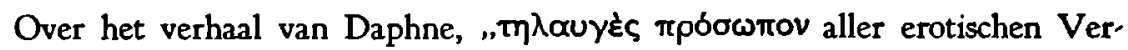
wandlungsgeschichten" (H einze p. 103), en Ovidius' eventueel voorbeeld, is meer dan één veronderstelling geopperd. Hoe voorzichtig wij behooren te zijn in dergelijke onderzoekingen, leert het arbitrair optreden van V ollg r a ff. Ovidius benut in de scene, waarin Daphne haar vader vraagt om levenslange maagdelijkheid, de Artemishymne van Callimachus en citeert dezen zelfs : dedit hoc pater ante Dianae (487; Callim. v. 6). Dit is zonneklaar voor $\mathrm{E} \mathrm{hwald} \mathrm{t.p.}$ en Von Wilamowitz (H. D. II p. 52 n. 4). Ook Vollgraff, in die periode, waarin hij trachtte te bewijzen, dat Ovidius een compendium benut had (O.M. p. 37 n. 80), twijfelde er niet aan, dat Ovidius hier op eigen gelegenheid Callimachus citeert : ,immo vel inde concluseris eum" in het verhaal van Daphne als geheel "poetico exemplari non usum esse". Eenige jaren later echter, tijdens zijn Nicander-conjunctuur, (N.O. p. 67 v.) meent hij Nicander als tusschenpersoon te moeten aannemen; hij is dan van meening, dat het voor een tijdgenoot van Augustus van geleerdheid getuigt, de Callimacheïsche hymnen te kennen, want hij geeft als motief, dat Ovidius niet werkelijk geleerd was. An sua cuique deus fit dira cupido? Het bedenkelijke van deze houding is echter vooral, dat hij Ovidius niet in staat acht, op eigen gezag te zinspelen op een auteur, dien hij op een bepaald moment niet als zijn eigenlijke voorbeeld zou 
hebben gekozen - Castiglio n 1, in een breedvoenge bespreking (p 117/64), heeft willen bewijzen, dat Ovidius een bepaald alexandnjnsch voorbeeld vnj getrouw gevolgd heeft, zijn conclusie gaat te ver, doch in elk geval heeft hij aangetoond, dat Ovidius in zijn verhaal vele alexandrijnsche motieven verwerkt heeft Voor $\mathrm{He}$ in ze is dit verhaal een hoeksteen van zijn theone, dat Ovidius in de Metamorphosen de goden zooveel doenlyk met majestest bekleedt; ons verhaal zou volgens hem een schunbare utzondering zijn op den algemeenen regel $\mathrm{Al}$ is $\mathrm{H}$ e $1 \cap z$ e's verklaning ten eenen male onjuist, het blifft zijn verdienste, gewezen te hebben op de belangrijke rol, die Amor in dit verhaal speelt $W_{1 j}$ willen in de bespreking der voornaamste punten aantoonen, dat het verhaal voornamelijk gekenmerkt wordt door speelsche irone en door modernseenng van god Apollo

Het verhaal opent met een scene tusschen Apollo en Amor Om den snoevenden Apollo terecht te wijzen, schiet de kleine Cupido hem een pill van liefdesverlangen in het hart, tegelijkertijd echter Daphne, de beminde, treffend met een pil van liefdesafkeengherd Deze scene is zeer merkwaardig Om den overgang tot stand te brengen van het eene verhaal naar het andere, was zij overbodig Want het heet, dat bij de Pythische spelen, ingesteld na de overwinning op den Python (het voorafgaande verhaal), Apollo zich met eikenloof

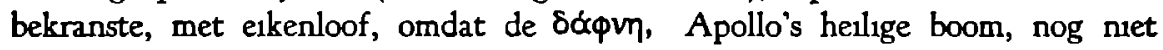
bestond Hiermede was de overgang naar Daphne tot stand gebracht $Z_{1 j}$ was ook overbodig, deze scene, voor het motiveeren van Daphne's afkeengheid. Want als jageres is Daphne, naar de gebruikelyke opvattingen, wars van de liefde Ovidius vertelt trouwens zelf, dat zi] haar vader's toestemming verkregen had om levenslang maagd te blyven Amor's pill kon bij haar dus veilig ontbreken. Sterker nog. de scene is niet slechts overbodig, doch zelfs de oorzaak van stoornissen in de ontwikkeling van het verhaal Door de verbinding van het motief van de plotselinge, door Amor's pijl veroorzaakte liefdesafkeengheid met het motief der ingeboren afkeerigheid der jageres (de schuldenng van het type der preutsche jageres wilde Ovidus in dit eerste liefdesverhaal niet missen) konden in de expositie wnjvingen niet uitblyven, 's dichters ingeniositeit heeft deze niet ongedaan kunnen maken $\mathrm{Er}_{r}$ moet dus een belangnjke reden geweest zijn, dat de dichter, het genoemde bezwaar ten spijt, toch opende met de scene tusschen Amor en Apollo Deze reden nu is mijns inziens, dat Ovidius ons by den aanvang van de liefdesavonturen der goden (.Daphne" is het eerste liefdesverhaal der Metamorphosen) den god voor oogen wil voeren, in wiens teeken al de volgende hefdesverhalen staan Deze god is het welbekende gevleugelde ventje, dat parmantig pijl en boog en fakkel voert $H_{1 j}$ heeft wel den schinn tegen zich, deze lascivus puer (456), doch hij is in feite de god der goden, aan wien de machtigsten onderworpen zijn Treft de menschen de tra deorum, de goden op hun beurt vallen ten prool aan de saeva Cuptdinis rra (443) De scene tusschen Amor en Apollo is de verhalende illustratie van wat de dichter elders constateert: regnat et in dominos ius habet ille deos (Her. 4 12) Daarom insisteert de dichter in het verdere verloop van het verhaal bij herhaling op de hevigheid en vruchteloosherd van Apollo's liefde (en dit nuet zonder irone: 
suaque illum oracula fallunt, 491 ; dit is wel een bekend motief van alexandrijnsche herkomst). Ook van Ovidius' poëzie geldt dus, wat Leg r a nd (p. 65 v.) opmerkt van de poëzie van den hellenistischen tijd, dat zij als het ware een door.

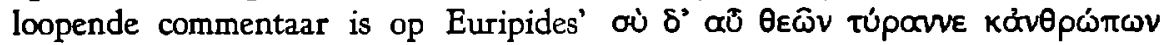
"Epws (o.a. geciteerd door Lucianus, Hist. quom. conscrib. 1). De scene tusschen Amor en Apollo is programmatisch. Een pendant is de schildering van Venus en Amor's oppermacht in "Raptus Proserpinae".

De ironie, die bij deze voorstelling van zaken ten doop stond, is $\mathrm{He}$ inze ten eenen male ontgaan. Toch is de heele scene van ironie doordrongen, bijv.

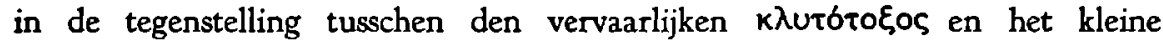
schuttertje, die niet fraaier tot haar recht komt dan juist hier, waar Apollo - zeer menschelijk - stoft op zijn recente overwinning op het monster.

Met Daphne en Apollo belanden we in de wereld der elegie. Dat zij niet schuw is of onschuldig, (gelijk R ib beck p. 300 meent), doch preutsch, rustica, blijkt, als wij illa velut crimen taedas exosa iugales (483) vergelijken met de woorden van de bekeerde jageres Arethusa : ego rustica dote Corporis erubui crimenque placere putavi (5.583 v.). Leerzaam voor de mentaliteit van de goden en van hun verlichten dichter is de pikant apostropheerende opmerking (waarmede de dichter tevens schertsend heenglijdt over de moeilijkheden in de expositie, die voortspruiten uit de tweevoudige verklaring van Daphne's afkeerigheid): ille quidem obsequitur, sed te decor iste, quod optas, Esse vetat, votoque two tua forma repugnat (488 v.). Forma mihi nocuit, zegt elders een schoone (2.572). Uiterst levendig wordt Apollo's enthousiasme geschilderd over haar schoonheid ; men lette op de anaphoren, de opeenstapeling van adjectieven, het enjambement, de extatische opsomming der fraaie lichaamsdeelen;
spectat inornatos collo pendere capillos 497
et 'quid, si comantur?' ait; videt igne micantes
sideribus similes oculos, videt oscula, quae non
est vidisse satis; laudat digitosque manusque
bracchiaque et nudos media plus parte lacertos.

Even hymnisch is Acontius' ontboezeming over Cydippe's schoonheid:

tu facis hoc oculique tui, quibus ignea cedunt Her. 19.55 sidera, qui flammae causa fuere meae,

hoc faciunt flavi crines et eburnea cervix, quaeque, precor, veniant in mea colla manus,

et decor et motus sine rusticitate pudentes,

et Thetidis qualis vix rear esse pedes.

In dit verfijnd genieten der vrouwelijke schoonheid zijn zoowel Apollo als Acontius leerlingen van den prediker der Liefdeskunst. Terwijl echter Acontius' lief een toonbeeld is van vrouwelijke elegance (motus sine rusticitate pudentes), is Daphne nog niet opgeklommen, de preutsche, tot de hoogte eener culta puella (inornatos capillos), en het vergaat Apollo met zijn 'quid si comantur?' (hoogst 
levendig gezegd) als Ovidius zelf : non est culta : subit, quid cultae accedere possit (Am. 2.4.37). Af te wijzen zijn dan ook de opvattingen van $L$ a $f$ a ye (Met. p. 107), die hier aan een herder en herderin uit Sulmo denkt, en van R and (p.60), die Apollo laat werven "in the manner of a pastoral swain". Wij zijn in de sfeer der erotische elegie, en $E \mathrm{~h} w$ ald in zijn commentaar (ad 497) citeert terecht R i b b e ck (p. 299), dat Apollo "der geriebene Grossstädter" is. Naar aanleiding van siqua latent meliora putat (502) - waarmede men vergelijken kan Acontius' cetera si possem laudare, beatior essem (61) - merkt dezelfde criticus op : „Wie Properz in einer seiner Elegien schliesst er von der Schönheit der sichtbaren Teile auf die verhüllten." Elegisch sentiment ademen ook Apollo's verzuchtingen tot de vluchtende Daphne:

me miserum! ne prona cadas indignave laedi 508 crura notent sentes et sim tibi causa dolendi!

aspera, qua properas, loca sunt -

Eenzelfde bezorgdheid voor lief's delicate schoonheid spreekt uit de woorden, die Vergilius Gallus in den mond legt, stellig naar diens eigen gedichten, in de tiende Ecloga (46/9), waarmede men nog vergelijken kan Propertius 1.8.5/8 (vergelijk ook Nonnus 16.91/3, Tibull. 4.3.9 v. ; Propert. 4. 4.27 v.). Apollo is, naar het woord van Ribbeck (p. 300), een "moderne figuur". (B eck's ,ut callidus perurbanus Romae", p. 13, is hiervan een echo.)

Ernst en tragiek zijn in heel het verhaal van Daphne verre te zoeken. Integendeel, de dartelheid gaat over in burleske, als het geciteerde tedere motief culmineert in: moderatius, oro, Curre fugamque inhibe! moderatius insequar ipse (510 v.). Met beminnelijke overdrijving wordt ook het minnekoozen geschilderd van den god na Daphne's metamorphose met den beminden boom : hij legt zijn hand op den stam ter hoogte van haar borst en voelt deze nog trillen onder de versche schors; hij omhelst de takken ut membra (555); hij kust het hout, dat zijn kussen tracht te ontwijken. En als hij zich noodgedwongen tot een Platoonsche liefde heeft opgewerkt, en haar rol bij de triumphen en (niet in de laatste plaats natuurlijk) haar standplaats voor Augustus' paleis heeft voorspeld, geeft de laurier haar jawoord, dat wil zeggen : zij neigt haar kruin ut caput (567). Men zou welhaast aan pantomimische voorstellingen denken. Weliswaar weten wij, dat de populaire Daphnefabel ook als pantomime werd opgevoerd (W a ser P. W. s. v. Daphne Sp. 2139.28 vv.), doch het is mijn bedoeling niet te beweren, dat Ovidius hier werkelijk een pantomime voor oogen heeft; het gaat om den indruk.

Wat dit verhaal dus vooral kenmerkt, is de speelsche ironie en de moderniseering. Het is bewust alexandrijnsch. Ovidius' eigen aandeel in de inkleeding en verwoording moet niet onderschat worden.

$$
\text { IO (I 583-750) }
$$

Dit verhaal is het eerste eener reeks van avonturen van Juppiter-op-zijwegen, en de eerste acte, als men de inleidende scenes aldus noemen mag, lichten ons 
van meet af in omtrent den wulpschen galant en zijn onvermijdelijke tegenspeelster, alspiedende Juno. Er zijn drie scenes. In de eerste (Juppiter en Io) tracht de god het maagdeken in het bosch te lokken : het is daar koel, en, mocht zij bevreesd zijn voor verscheurende dieren, zij heeft een beschermer, en welk een beschermer ! $\mathrm{Zijn}$ insidieuze voorstellen lijden echter schipbreuk : 'ne fuge me !'. fugiebat enim (597). Juppiter hult de aarde in breede duisternis; de eerste scene besluit : occuluit / tenuitque fugam / rapuitque pudorem (600); het geometrische vers verhoogt de suggestie. De tweede scene (Juno) speelt zich aanvankelijk in den hemel af, waar de godin zich verbaast over den merkwaardigen nevel, dien zij - typeerend - met Juppiter in verband brengt; als zij haar gemaal boven niet vindt, ijlt zij onverwijld naar de aarde. Verwondering leidt tot argwaan, argwaan snel tot zekerheid, zekerheid terstond tot ingrijpen. Aan het tempo van Juno's gedachten is het tempo van de vertelling aangepast; want na een rustig begin volgt alles steeds sneller op elkaar, als een lawine. Vernietigend is de welhaast automatische verbinding van "merkwaardige nevel" en "waar steekt Juppiter ?"; met een quasi-vermoeid gebaar (men lette op den val der monosyllaben aan het verseind) voegt de dichter er ten overvloede aan toe: ut quae Deprensi totiens iam nosset furta mariti $(605 \mathrm{v}$.). Totiens spreekt boekdeelen. Vermakelijk zijn haar woorden aut ego fallor Aut ego laedor (607) met het schijnbaar passieve fallor (ik vergis mij) en het sterk passieve laedor (ik word gekrenkt). In de derde scene (Juppiter, Juno en Io) strijkt Juppiter, na een adembenemende schermutseling, de vlag. Uit den nevel doemen op Juppiter en - een koe. Juppiter heeft het eerste voordeel; Juno, perplex, ziet zich gedwongen de schoonheid der koe te beamen. Zich echter snel herstellend, vraagt zij naar de herkomst van het beest, het mes in de wonde rond draaiend, nu zij de wonde plek gevonden heeft : et cuius et unde Quove sit armento (613 v.). Nog trekt Juppiter het hoofd uit de strop : uit de aarde geboren, zoo liegt hij. Doch bliksemsnel volgt de genadeslag: petit hane Saturnia munus (616). Het moeilijk parket, waarin Juppiter door dezen zet gebracht wordt, schildert de dichter met niet gering leedvermaak; kort en helder wordt 's goden penibel beraad geschetst: suadere en dissuadere, termini technici, aan de techniek der suasorice ontleend ( $\mathrm{Ehwald}$ ad 617 ) en ostentatief gebruikt, verhoogen de ironie. Met een bezwaard hart staat hij de dierbare koe af. Teekenend voor Juno zoowel als Juppiter is de slotopmerking, dat de godin, ofschoon in het bezit der paelex (622), nog niet gerust is, en nog steeds beducht voor machinaties van haar gemaal; de dichter illustreert haar ongerustheid door het geometrische vers en de drievoudige variatie van het eene begrip : diva metum / timuitque Iovem et / fuit anxia furti. "Le ménage de Jupiter manque entièrement de gravité" (B o i ss i e r P. A. p. 376). Het is niet verwonderlijk, dat dezie meesterlijke episode de critici aan de comedie herinnerd heeft. Ribbeck (p. 301; door $\mathrm{Ehwald}$ ad 601 geciteerd) spreekt van: „Fast wie in einer Komödienscene etc."; naar dezen, doch zonder hem te vermelden, noemt Peters (p. 52) Juno "quasi uxor irata comoediae" ( $\mathrm{He}$ inze nochtans ignoreert deze episode). Eitrem (p. 456) gaat zelfs verder, en bespeurt in Ovidius' relaas nog het stramien eener comedie; veel althans, zoo zegt hij met wijze restrictie, zou in 
een comedie op zijn plaats zijn. Dit laatste is waar, en stellig zou Ovidius een voortreffelijk comediedichter geweest zijn, zooals niet enkel "Io" bewijst, doch ook „Callisto”, „Europa” en „Semele” (zie daar). R a n d (p. 63) mag de Metamorphosen met het volste recht een Divina Comoedia noemen.

Aldus dan begint het eerste verhaal van Juppiter verliefd. Is het te vermetel, te zeggen, dat deze inleiding bedoeld is als exemplarisch voor alle volgende gevallen? In "Callisto" herinneren zich zoowel Juppiter als Juno het geval Io. Door al Juppiter's galante avonturen waart het grimmig spook zijner alerte gemalin, en hieraan is de charme dezer verhalen voor een niet gering gedeelte te danken. Men zie vooral "Callisto", "Semele", „Echo", ook "Ino" en „Ganymedes".

Niet minder burlesk worden de wederwaardigheden van Io koe beschreven. Over Io had een der neoterici, de beroemde Calvus, een epyllion gedicht. Wat hierin precies behandeld werd, is ons onbekend; de conclusies, die B i t (p. 211/2) en Skutsch (p. 36 n. 2) uit de behouden luttele fragmenten trekken, zijn volkomen arbitrair (en tegenstrijdig); een blik op Catullus' epyllion had moeten volstaan om de onmogelijkheid te begrijpen, inhoud en opbouw van dergelijke producten ook maar bij benadering te achterhalen. Spinnewebben zijn geen touwladders. Wel kunnen wij met eenige zekerheid aannemen, dat de volgende motieven in Calvus' "Io" voorkwamen :

1. Gras en loof zijn haar voedsel.

Calvus fr. 9 M. herbis pasceris amaris.

Prop. 2.33.11 quernis laesisti frondibus ora, mandisti et stabulis arbuta pasta tuis.

Ov. H. 14.96 fronde levas nimiam caespitibusque famem.

M. 1.632 frondibus arboreis et amara pascitur herba.

2. $Z_{i j}$ spreekt niet meer, doch loeit (en schrikt daar zelf van).

Prop. 2.33.10 et pecoris duro perdere verba sono.

2.28.17 Io versa caput primos mugiverat annos.

Ov. H. 14.87 an satis est poenae teneram mugisse puellam -

91 conatoque queri mugitus edidit ore

92 territa voce sua.

M. 1.637 et conata queri mugitus edidit ore pertimuitque sonos propriaque exterrita voce est.

3. Zij schrikt van haar eigen horens.

Prop. 2. 33.9 vermeldt wel de horens, doch niet haar schrik;

2.28.17 legt hij misschien verband tusschen het loeien en de horens : Io versa caput primos mugiverat annos.

Ov. H. 14.92 territaque est forma, territa voce sua.

Am. 1.3.21 zinspeelt op een bekend motief : carmine nomen habent exterrita cornibus Io etc.

Volgens Ov. Her. 14.89 v. en Met. 1.639 vv. ziet zij haar horens in de rivier haars vaders, misschien naar Calvus; zeker is het motief naar het hart der 
alexandrijnen. Het ontbreken van deze bijzonderheid bij Propertius behoeft niet $z$ waar te wegen, omdat deze niet een volledig résumé wil geven van deze cause célèbre, doch slechts de bekendste motieven aanstipt. Her. 14 brengt het loeien in verband met het zien der horens, waarover zij wil klagen; - mogelijk naar Calvus, mogelijk ook eigen combinatie van Ovidius, die over haar verwondering uitweidt bij het zien van haar verbijsterend figuur.

\section{Sentimenteel pathos en apostrophe.}

Calvus fr. 9 M. a virgo infelix herbis pasceris amaris.

De pathetische apostrophe is kenmerkend voor de neoterische epyllia $(\mathrm{J}$ a $\mathrm{ck}$ son p. 41 ; Catullus 64. 71 : a misera ; Cinna fr. $6 \mathrm{M}$. in ,Zmyma" te flentem etc.; Verg. Ecl. 6.47-52, waarschijnlijk naar Gallus : a virgo infelix.). Echo's hiervan horen wij bij Propertius en Ovidius.

Prop. 2.33.11 a quotiens quernis laesisti frondibus ora etc.

Ov. H. 14.93 quid furis, infelix, quid te miraris in unda? etc. (de gansche passage is gechargeerd pathetisch)

M. 1.634 infelix.

Het bovenstaande gaat, deels zeker deels waarschijnlijk, op Calvus' befaamde epyllion (de sensatie en de glorie van een eigen Romeinsch model !) terug. Enkel bij Ovidius, doch zoowel in Her. 14 als in de Metamorphosen, vinden wij nog de motieven van het slapen op den grond $(100: 633)$ en van het drinken uit de rivier (97 : 634). Het feit, dat Propertius deze niet benut, bewijst, zooals boven betoogd is, nog niet, dat zij niet bij Calvus voorkwamen; doch aan den anderen kant mogen wij veilig aannemen, dat Ovidius' fantasie en zin voor ironie zich niet onbetuigd hebben gelaten; hij kan in de Metamorphosen weer van zijn eigen vondsten gebruik gemaakt hebben.

Dat Ovidius dus in de Metamorphosen Calvus benut, blijkt uit het bovenstaande genoegzaam ; hij citeert hem zelfs. Hij vermijdt de apostrophe, doch vult de reeds genoemde motieven fijntjes overdrijvend aan : Io wordt des nachts in ketenen geslagen ; zij wil smeekend tot Argus haar armen uitstrekken, doch heeft geen armen om smeekend tot hem uit te strekken (met berekende herhaling van bracchia tendere, 635); zij moet slapen op den grond, en deze is non semper gramen habens (633); zij moet drinken uit rivieren, en deze zijn limosa (634). Op deze, betrekkelijk sober gehouden schildering, volgt dan echter in haar ontmoeting met haar vader een uitbundige burleske. Lacrimis omnia plena madent. Het begint met een gevoelig ripas, ubi ludere saepe solebat, Inachidas ripas (639 v.). Noch haar oude speelnooten, noch ook haar vader herkennen haar. Door zijn handen te likken, door zijn handpalmen te kussen, door tranen en door tenslotte met een poot haar naam in het zand te schrijven(!), maakt zij zich bekend. Welk een smartelijk weerzien ! Hoe onklemt de rampzalige haar horens, stamelend ,me miserum', zij kreunt en loeit terug. Inachus heeft visioenen van een stier als schoonzoon, en van kleinkinderen uit de kudde (,réflexion comique", B o issier P. A. p. 378); geen wonder, dat hij het betreurt, als god, geen eind te kunnen maken aan dit rampzalig leven (vgl. Philetas' Demeter, Bion I, epit. Adon., 52 v.; Vergil. 12. 879 v.; Nonnus 11.325/7). Volgens $\mathrm{He}$ inze (p. 70) 
is de opzet dezer scene „dem Dichter Gelegenheit zu geben, durch eine Rede auszudrücken, was etwa ein Vater in solcher gewiss sehr ungewöhnlichen Lage empfinden mag". Niet aan eenieder is het gegeven, in zoo korte woorden zoo geestig te zijn. Of een ontmoeting tusschen Io koe en vader Inachus door Calvus geschilderd werd, ja dan neen, stellig is zij bij Ovidius een onverholen persiflage van de al te lacrimoze pathetiek van Calvus en de zijnen. (Zie ook nog verderop.)

Juppiter zendt Mercurius uit om Argus te dooden. De verzen waarin dit beschreven wordt, zijn een klein eilandje van sobere epiek en sobere reminiscenties tusschen de voorafgaande en de nog volgende scenes van persiflage, en, waar het ingrijpen van Juppiter de peripetie in het verhaal beduidt, een gelukkige greep des dichters. Juppiter wordt stijlvol omschreven als superum rector (668), Mercurius als natum, quem lucida partu Pleias enixa est (669 v.). In het kort herinnert de dichter aan de uitvoerige schilderingen van Mercurius' toebereidselen. tot de reis bij Homerus (XXIV $340 \mathrm{vv} .=5.44 \mathrm{vv}$.) en Vergilius (4.238 vv.): parva mora est alas pedibus virgamque potenti Somniferam sumpsisse manu tegumenque capillis $(671 \mathrm{v}$.), ofschoon geen twee verzen later vermeld wordt, dat Mercurius hoed en vleugels weer aflegt. De bedoeling dezer verzen is, ons even het bekende beeld van Mercurius voor den geest te halen (zie onder "Ino"). Nog korter geschiedt dit F. 4.605: Tartara iussus adit sumptis Caducifer alis.

Het verhaal van Syrinx, dat hierop is ingeweven, wordt afzonderlijk besproken. Aan het eind wordt weer de rampzalige koe ten tooneele gevoerd (729 vv.); ook hier wordt de neoterische pathetiek gepersifleerd. Op de knieën, opgeheven (bij gebrek aan armen) den kop, onder gezucht, geween en geloei, schijnt zij om deernis te smeeken. Luctisono mugitu (732) aan het verseinde, speelt met de neoterische versus spondiaci en composita, mogelijk is het een citaat van Calvus, zeker is het in den trant der neoterici. Luctisonus is, als ik het wel heb, het eenige compositum op -sonus, dat bij Ovidius voorkomt; hij schijnt dit soort composita te vermijden : zoo vinden wij bij hem wel armifer, doch niet armisonus; wat echter de neoterici betreft : alleen al in Catullus' epyllion vinden wij -sonus niet minder dan viermaal (fluentisonus, 52 ; clarisonus, 125 en 320 ; raucisonus,

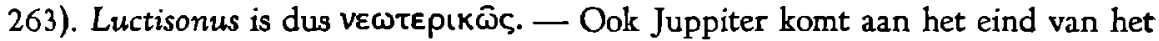
verhaal nog eenmaal voor het voetlicht, en het is een zeer potsierlijke Juppiter. Wel verre van Juno's wreedheid met kracht te betoomen als de divumque hominumque pater rex, smeekt hij haar op smadelijke wijze om erbarmen, de armen om haar hals geslagen (een pathetisch soort knieval), terwijl hij een zwaren eed zweert, dat het meisje haar geen leed zal berokkenen. Zoo keert het einde naar het begin terug. Het is een burleske comedie, afgerond van opbouw : .1 Juppiter en Juno; 2. Io koe; 3. Juppiter en Mercurius (episch intermezzo); 4. Io koe; 5 . Juppiter en Juno. Vermenschelijking en ironie vieren in ,Io" hoogtij.

\section{SYRINX (I 698-712)}

Het verhaal van Syrinx is in dat van Io verweven. Onmiddellijk na elkaar wordt dus de achtervolging verteld van Daphne, van Io, en van Syrinx. Dat hierdoor het gevaar van monotonie niet gering was, is duidelijk. Ovidius heeft 
deze moeilijkheid echter opgezocht om er zijn meesterschap aan te demonstreeren, en wellicht ook om een bepaald effect te bereiken; want, in plaats van te vermoeien, dwingt hij onze bewondering af door zijn kunst van variatie en door de climax, die in deze reeks van achtervolgingen valt op te merken. L a f a ye (Met. p. 93) ziet 's dichters kunst in het volgende : van "Daphne" wordt vooral de eerste acte geschilderd, de achtervolging ; in "Io" wordt bijna aanstonds de metamorphose gegeven, terwijl aan de schildering der vadersmart een groote plaats is ingeruimd ; "Syrinx" daarentegen is verkort "par un de ces subterfuges, qui sont les trouvailles des gens d'esprit". "Il est impossible de se jouer avec plus de souplesse d'une difficulté qu'on s'est soi-même créée à plaisir". Ik zou willen wijzen op de volgende climax : in "Daphne" zegt Apollo alles, wat hij op zijn hart heeft ; in "Io" ziet Juppiter (althans, zoo stelt de dichter het voor) zich plotseling midden onder zijn woorden gefrusteerd door haar vlucht : , ne fuge me'. fugiebat enim (597); in "Syrinx" breekt het verhaal juist af, als Pan zijn mond opent : talia verba refert - restabat verba referre (700): men lette op de ongehaaste ankkondiging zijner woorden, en dan de coupure met de berekende herhaling van verba referre. Wat hij wil zeggen, weten wij wel ongeveer na het voorafgaande : c'est toujours la même chanson.

Syrinx is een der meest typische en representatieve gevallen uit de uitgebreide reeks van achtervolgde schoonen (liefst jageressen); Pan is hier de held,

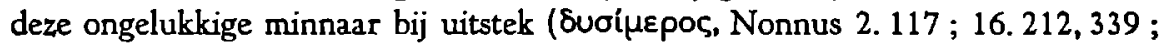
48. 672). Ovidius stipt alle conventioneele motieven aan, en men krijgt den indruk, dat hij hiermede het typische karakter van dit soort verhalen ook heeft willen suggereeren. Syrinx is: de meest bekende onder haar vriendinnen; hartstochtelijk jageres; gekleed als Diana; wars van de liefde; tallooze malen vergeefs door de halfgoden van bosch en veld nagejaagd (vergelijk „Pomona”). Ook minnaar Pan wordt op de gebruikelijke wijze geteekend, zooals uit de schilderkunst bekend, het hoofd met sparregroen omkranst (dit wordt van hem verteld, als hij jaagt op Syrinx, 1.699 ; op Pomona, 14.638; op Lotis en andere nymphen, Fast. 1. 412 ; op Oenone, Her. 5. 137): Arcadio pinus amica deo (Prop. 1.18. 20). Na de onderbreking van de directe vertelling wordt het conventioneel karakter van het verhaal nog meer voelbaar : afwijzing, achtervolging, uitputting, smeeken om hulp, metamorphose, verzuchtingen van den minnaar; - alles volgens het gebruikelijke recept, en toch steeds prettig om te lezen, een luchtig spel vol beminnelijke ironie, de ideale vorm voor dit soort verhalen.

\section{PHAETHON (I 750 - II 400)}

$\mathrm{K} \mathrm{n}$ a a $\mathrm{ck}$, steunende vooral op de frappante overeenkomsten tusschen Ovidius en Nonnus (boek 38), heeft de theorie ontwikkeld, dat beide dichters in hun verhalen van Phaethon een alexandrijnsch voorbeeld benut hebben. $H i j$ vond veel bijval, o.a. van $\mathrm{E} h$ wald in diens commentaar. Bestreden, niet slechts in details, doch ook in de grondstelling, werd zijn theorie door B ra u ne (p. 7/27). volgens wien Nonnus Ovidius direct benut heeft. Hangende de kwestie der afhankelijkheid, en tevens omdat andere voorbeelden ons leeren, dat men, niet 
in het bezit van zijn voorbeeld, Ovidius' graad van afhankelijkheid en van zelfstandigheid bijna niet kan bepalen, hebben wij ons in de bespreking van "Phaethon" ervan onthouden, het alexandrijnsch voorbeeld in het geding te brengen. Dat echter de liefde van Helios tot Clymene, de moeder van Phaethon, ergens in de alexandrijnsche poezie een vermaarde behandeling gekregen heeft, kan nauwelijks betwijfeld worden (zie onder „Leucothoe”). Wij zouden vooral willen weten, hoe de alexandrijn de verhouding tusschen Helios en de zon behandeld heeft. Geen andere god is zo nauw verbonden met zijn natuurlijke basis ; toch wordt Helios in talrijke mythen voorgesteld als een zuiver goddelijke persoon ( $R$ a P P in Roscher s. v. Helios Sp. 2015 vv.); gelet op den rijkdom aan individueele trekken in de schildering van Helios in de Demeterhymne, is de zonnegod in de oudere Heliosmythen een handelende persoon en nog niet door de gebondenheid aan het natuurlichaam verstard (id. Sp. 2020). Hoe heeft de alexandrijn hem behandeld? Bij Ovidius is het moment van personificatie sterk. De materialen, waaruit Sol's paleis is vervaardigd, zijn : goud, goudbrons, ivoor en zilver. Volgens Bartholomé (p. 17 vv.) zijn zij, ,rein epischer Schmuck" en wil Ovidius in zijn beschrijving van de regia Solis den tempel van Apollo Palatinus in pracht en glans overtreffen. Dit is onjuist; zij moeten niet zoozeer de kostbaarheid van het paleis demonstreeren, alswel de schittering der zon illustreeren, hetgeen ten overvloede blijkt uit de adjectiva : clara, micante, flammasque imitante, nitidum (2.2 v.), en uit radiabant lumine (4). (Zoo is bij Statius, Th. 7.43 v., aan de woning van Mars, den ijzeren oorlogsgod, alles van ijzer.) De deuren van het paleis zijn versierd met reliefs van : zee, aarde en uitspansel, elk met de passende wezens; eerst worden uitvoerig de goden der zee geteekend (hierbij vinden ook de dieren der zee hun plaats), daarna wordt schematisch geschetst, hoe wij ons de aarde en het hemelgewelf moeten denken; men lette op de systematiek der verzen: terra viros urbesque gerit silvasque ferasque Fluminaque et nymphas et cetera numina ruris $(15 \mathrm{v}$.); het hemelgewelf is versierd met de twaalf teekenen van den dierenriem. Op de reliefs der deuren wordt dus in al zijn geledingen het heelal geschetst, dat door de zon beheerscht en bestreken wordt. Sol zelf is gekleed in een scharlaken kleed; er gaat een geweldige gloed van hem uit; zijn troon is versierd met smaragden, op wier schittering groote nadruk wordt gelegd (in solio claris lucente smaragdis, 24). De hofhouding wordt gevormd door: Dag, Maand, Jaar, Eeuw (Saecula, 26, pluralis metri causa), Uren (op gelijke afstanden opgesteld!) en de vier Jaargetijden, die elk toepasselijk uitgedost zijn. Naar R a p p (Sp. 2023) opmerkt, wordt Helios door Plato (rep. 7, p. 516) en in de Orph. hymn. 7 (Xpóvou

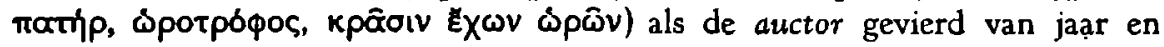
jaargetijden; in de hofhouding bij Ovidius ziet hij meer personificaties naar Romeinschen aard. Voor de schildering van den zonnewagen geldt, wat voor de schildering van paleis en troon geldt. De materialen moeten de schittering van de zon tot uitdrukking brengen : het is alles goud, zilver, chrysolithen en gemmen, wat eraan blinkt. Ovidius heeft in de eerste plaats den glans, en niet de kostbaarheid der metalen voor oogen, zooals de slotregel der schildering bewijst : clara repercusso reddebant lumina Phoebo (110). Slechts naar den vorm 
der beschrijving wil Ovidius aan Homerus' befaamde schildering herinneren van Hera's kostbaren wagen. Op deze formeele overeenkomst met Homerus wijzen Ehwald (ad 107) en A. Rohde (p. 12), volgens wie slechts het rhetorisch raffinement in de woordplaatsing Ovidius' eigen bijdrage is. Er is echter tusschen beide dichters een principieel verschil in de motieven hunner keuze van materiaal : bij Homerus zijn de materialen kostbaar, omdat het den wagen betreft eener godheid, en niet de geringste, bij Ovidius daarentegen zijn de materialen glanzend en schitterend, omdat het den wagen betreft der schitterende zon. (Zie ook onder „Raptus Proserpinae".)

Uit dit alles blijkt overduidelijk, dat wij hier niet te doen hebben met den mythologischen persoon Sol-Helios, doch met een personificatie van het zonnelichaam : in alles worden de eigenschappen en werkingssfeer van het zonnelichaam gesymboliseerd. Wij hebben hier niet te doen met Sol zelf, doch met een "figuration du Soleil", zooals R i pert (p. 127) opmerkt, op wien de hofhouding den indruk maakt van "le ballet de la plus somptueuse des revues". Hij vermoedt, dat Ovidius zich heeft geinspireerd op mozaieken of op tooverballets uit theaterscenes van zijn tijd; - mogelijk, doch oncontroleerbaar. De woorden, waarmede Phaethon dezen Sol aanspreekt, hoe verrassend ook in den mond van den zoon, - o lux inmensi publica mundi (35) -, zijn op deze figuur werkelijk van toepassing.

Naast het moment van uiterste personificatie treft ons in de uitbeelding van Sol het moment der vermenschelijking. Sol zet bijv. zijn stralenkrans af (40/1) om zijn zoon te kunnen omhelzen. La marre (p. 190) haalt dit aan als een der gevallen, „où les dieux et personnages légendaires paraissent si embarrassés ou si peu soucieux des attributs et des figures symboliques qui leur sont attachés, que la familiarité de leur langage et de leur maintien produit un effet comique, presque grotesque, qui ressemble à de la parodie". Deze hieratische figuur kent zoowaar menschelijke gevoelens. $\mathrm{Na}$ Phaethon's noodlottige vraag schudt hij spijtig het illuster hoofd en put zich uit in argumenten om zoonlief tot betere gedachten te brengen. Hij talmt met het vervullen van den wensch zoo lang mogelijk, en slaakt van bange voorgevoelens diepe zuchten. Hij tracht den toon te treffen, die weerklank vindt in het hart van den onbesuisden knaap, als hij zegt, dat zelfs Olympus' heerscher den wagen niet vermag te mennen, et quid, mijn jongen, Iove maius habemus? (62). Verbeeld je ook niet, dat de reis een plezierreisje als door de Campagna: geen luci urbesque deorum delubraque ditia donis (76 v.). Hoe warm dit vaderhart klopt, zullen wij nog aanstonds zien. Hier willen wij nog wijzen op een bekentenis van zeer menschelijke gevoelens : dit cosmisch heerschap, deze onverstoorbare regent van Dag, Maand en Jaar, komt er rond voor uit, dat hem op zijn hoogen post niet zelden de schrik om het hart slaat $(65 \mathrm{v}$.), dat Tethys zijn nederwaartschen gang met bezorgdheid pleegt gade te slaan $(69$ v.). Het zeer zakelijke en het zeer menschelijke spelen dooreen. Het zeer menschelijke treft ons ook in Sol's zinnelooze smart om den dood van zijn zoon, waaraan hij zich overgeeft zonder eenig gevoel voor verhoudingen : datque animum in luctus et luctibus adicit iram (384): hij gaat in staking, en deinst er niet voor terug, in mokkende sarcasmen Juppiter van 
wreedheid en willekeur te betichten, hetgeen, zooals wij zullen zien, de waarheid geweld aandoet. Hij moet door dreigementen tot de orde geroepen worden, en koelt dan nog zijn woede op de paarden, aan wie hij den dood van zijn zoon wijt : saevit enim (400) - al te menschelijk. Doch ook hier wordt het zeer menschelijke verweven met het zeer zakelijke. Zijn eerste reactie op den dood van zijn zoon is, dat hij zijn gelaat verbergt; met andere woorden, zoo zegt de dichter : de wereld is een dag sine sole; gelukkig, zoo voegt de dichter eraan toe, verspreiden de branden licht, aliquisque malo fuit usus in illo! (332). Zijn diepst menschelijke gevoelens openbaren zich in atmospherische verschijnselen (vergelijk Lucifer in "Ceyx et Alcyone", ook „Aurora" en "Leucothoe"). De vertwijfelde mensch is het leven en het licht der zon moe; de vertwijfelde vader van Phaethon, die zelf de zon is, haat dus zichzelf : squalidus is hij en expers Ipse sui decoris, qualis, cum deficit orbem, Esse solet, lucemque odit seque ipse diemque (381 vv.). Dit is het spel met de dupliciteit ten top gevoerd.

$\mathrm{E}_{\boldsymbol{r}}$ is in dit verhaal ook een moment van moderniseering, en wel vooral in de schildering van Sol's paleis. Wees Ehwald (ad 2.1) er reeds op, dat het paleis door zijn fastigium aan een tempel herinnerde, betoogde reeds $\mathrm{Br}$ a u n e (p. 11), dat Ovidius een Romeinschen tempel voor den geest had, B a $\mathrm{r}$ th o l o m é (p. 17 vv.) beweert, en mijns inziens terecht, dat Ovidius den tempel van Apollo Palatinus voor oogen heeft. Het paleis heeft het karakter van een tempel, blijkens de zuilen, de relief-gesmukte vleugeldeuren en den gevelspits. Het paleis ligt hoog (adclivi limite, 19); Sol betitelt het zelf als arx. Aldus voelen wij ons herinnerd aan den "Palatijn des hemels" uit den Godenraad in bk. I (arx, 1. 163 $=$ Palatia caeli, 1.176; met adclivi limite, 2.19, vergelijk via sublimis, 1. 168). Barthol o mé wijst er verder op, dat bij de ontvangst van Phaethon men meent een cultusbeeld uit de cella plotseling tot leven te zien komen, dat Apollo als lichtgod met Sol gelijk staat, dat een vierspan met Sol den tempel op den Palatijn bekroonde. Deze hypothese, dat Sol's paleis mede geinspireerd is op den tempel van Apollo Palatinus (reeds R i pe rt p. 127 sprak van „aussi omé que le Palatin de Rome"), verklaart niet slechts het tempelachtige karakter van het paleis, doch ook de ligging ervan, een probleem, dat de gemoederen der geleerden lang in beroering heeft gehouden. $\mathrm{K} \mathrm{n} \mathrm{a} \mathrm{a} \mathrm{ck} \mathrm{(p.} 27$ v.) vermoedde, ofschoon van beide beschrijvingen niets bekend is, dat Ovidius een schildering van Oceanus' paleis door den onbekenden Alexandrijn contamineerde met Euripides' schildering van den Zonneburg; hiermede zou de opvallende plaats verklaard zijn, die op de deurreliefs aan de goden der zee is ingeruimd. Eh wald (ad 2.8) sluit zich voorzichtig bij hem aan. A. Rohde (p. 12 v.) wijst deze verklaring af, en Bra une (p. 11) verklaart, dat volgens de voorstellingen der ouden Sol's paleis op een hoogen zeeoever lag. De verklaring van de uitvoerige beschrijving der zeegoden ligt wel in het genoegen, dat Ovidius steeds heeft aan deze pittoreske en vermakelijke wezens (zie onder „Salmacis”); met lette bijv. op den kolossalen Aegaeon met zijn honderd armen, die zich door walvisschen laat dragen, zooals andere zeegoden door visschen ( $\mathrm{h}$ w ald ad 10 ).

Romeinsch gekleurd zijn ook de termen, waarin Ovidius van de sterren spreekt. Deze vormen een nachtwacht, des ochtends rukken zij in, terwijl de 
stoet gesloten wordt door Lucifer, den dienstdoenden officier ; de termen agmin cogit (114) en caeli statione (115) zijn, zooals $\mathrm{Ehwald}$ opmerkt, aan het krijgswezen ontleend.

De consternatie, door Phaethon's dollen rit allerwegen verwekt, beziet Ovidius van de lachwekkende zijde; men zou van een cosmische comedie kunnen spreken. Achtereenvolgens worden de perikelen beschreven van het uitspansel (met de teekenen van den dierenriem), van de aarde (en wel van de hoogste deelen, de bergen, tot de laagste, de rivieren) en van de zee (met de visschen en zeegoden) - denk aan de reliefs op de deuren van Sol's paleis -, terwijl ook de onder. wereld terloops in de dwaasheid betrokken wordt. Ook de goden moeten het ontgelden. Nereus zit met gemalin en dochteren in diepe grotten weggedoken, en ook daar nog is het water lauw. De aarde splijt, door de barsten dringt het licht in de onderwereld door, tot ontzetting van Pluto en zijn gemalin (260 vv.): Ovidius zinspeelt op de panische ontzetting van den heerscher der duisternis bij Homerus (XX 61/5; vgl. Hesiod. Theog. 850), als het licht in het doodenrijk dreigt door te dringen : met een luiden kreet springt hij op van zijn troon (zie ook onder "Raptus Proserpinae"). Een weinig verheven figuur slaat ook de heerscher der wateren, Neptunus hoogstpersoonlijk. Ieder herinnert zich uit de Aeneis, hoe hij, de stormen bedwingend, majestueus uit de golven rijst (1.126). Geheel anders is het nu : driemaal waagt hij het, het norsch gelaat en de armen uit de wateren te verheffen, doch driemaal ook duikt hij vanwege de hitte wijselijk weer onder. Tenslotte maakt zich Moeder Aarde tot tolk aller gevoelens. De episode van alma Tellus is een van Ovidius' dartelste fantasieën. Hij geeft een plastische beschrijving der getourmenteerde godin, waarbij drastisch "earth-person and earth-thing are decidedly mixed" (Mille r p. 530). Verdord, de haren verzengd, oogen en gezicht met asch bedekt, van de hitte bijna stikkend, komt zij tot aan haar schouders te voorschijn en houdt de hand voor het hoofd. Dit alles zijn persoonlijke trekken. Daarnaast echter vernemen wij, dat de bronnen zich teruggetrokken hebben in opacae viscera matris (274), dat zij lager ligt dan gewoonlijk, dat een siddering van haar aardbeving beteekent; het spel met de dupliciteit der godin wordt tot in de uiterste consequentie voortgezet : suumque Rettulit os in se (302 v.). Deze details zijn een passende omlijsting harer woorden. De zengende hitte ten spijt, houdt zij, in niet minder dan tweeëntwintig verzen, een betoog, even klemmend als voorbeeldig van dispositie. Beginnend met (I) een beroep op Juppiter's medelijden en een korte schildering van haar rampzaligen toestand, gaat zij vervolgens over tot (II) de argumentatie, waarbij zij, in berekenden climax, opklimt van (A) haarzelf, de aarde, die dit lot niet verdient vanwege haar onverpoosden arbeid voor (a) de dieren (loof), (b) de menschen (voedsel), (c) de goden (wierook), via (B) de zee en het onrecht, dat Neptunus wordt aangedaan, tot (C) den hemel, Juppiter's eigen rijk en bedreigde veiligheid, om tot slot (III) de conclusie te trekken (dreigende chaos) en Juppiter tot ingrijpen op te wekken. Het behoeft geen betoog, dat de systematiek dezer rede, vooral in de gegeven omstandigheden, te apert is, dan dat zij niet bedoeld zou zijn en als zoodanig herkend zou willen zijn, dat Ovidius hier dus niet het slachtoffer is zijner rhetorische opleiding, 
doch een show geeft en speelt met de declamaties (zie ook onder „Ino", „Lycii coloni”, „Aurora" en „Concilium deorum").

Als de nood het hoogst is, grijpt Juppiter ook werkelijk in, niet echter dan na de hemelingen en Phaethon's vader zelf bezworen te hebben, dat de dreigende algeheele vernietiging hem hiertoe noopt. Het is een apologiseerende Juppiter. Dit is een aanmerkelijke terugval van de verbolgen zelfheerlijkheid des almachtigen vaders, waarvan Lucretius spreekt. Men vergelijke slechts : Lucretius : at pater omnipotens, ira tum percitus acri (5.399); Ovidius : at pater omnipotens, superos testatus et ipsum (304). Dit belet Sol niet, na de catastrophe, Juppiter van wreedheid en willekeur te betichten. Doch ook dan zien wij Juppiter nog niet terstond fors doortasten. Met de andere goden, die Sol omringen (circumstant, 394) en hem nederig smeeken (supplice voce, 396), om toch van zijn onzalig voornemen af te zien, giet hij olie op de golven (missos quoque Iuppiter ignes Excusat, 396 v.), om er eerst daarna regaliter dreigementen aan toe te voegen. Men stelle zich dezen dollen godenraad voor.

Het epyllion van Phaethon is dus doortrokken van den alexandrijnschen geest; vermenschelijking, moderniseering, het spel met de dupliciteit van de eponyme godheden en ironie vieren er hoogtij. Indien hij een alexandrijnsch voorbeeld heeft gehad en dit in groote lijnen gevolgd heeft, heeft Ovidius' eigen exuberante verve zich stellig ook niet onbetuigd gelaten.

\section{CALLISTO (II 409-530)}

Het schijnt, dat de sage van Callisto zich in de belangstelling der alexandrijnsche dichters heeft mogen verheugen; Hein ze (p. 109 v.) bespreekt uitvoerig de veranderingen, die op rekening van deze dichters komen. Wij zullen in onze bespreking eenige malen gelegenheid hebben, op den invloed te wijzen van alexandrijnsche voorgangers op Ovidius' versie, doch ook op Ovidius' zelfstandigheid. Het verhaal bestaat uit twee deelen, de aanranding van Callisto door Juppiter en den nasleep vandien, en de wraak van Juno.

Men lette op de groote en kleine middelen, waarmede Juppiter's wulpschheid geironiseerd wordt. Twee verzen teekenen hem ten voeten uit (B o i s si e r R. R. p. 204 en Lamarre p. 190 : "gaillardement"): 'hoc certe furtum coniunx mea nesciet' inquit, 'Aut si rescierit, sunt, o sunt iurgia tanti!" (423 v.). Tevens doemt

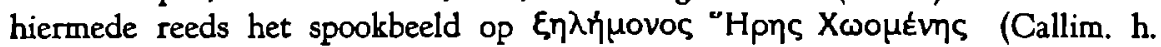
Artem. 30 v.). $E_{r}$ is bovendien een verwijzing in vervat naar het verhaal van Io (evenals in de vv. $523 \mathrm{v}$.), waarin Juno wel degelijk lont rook. Ribbeck (p. 302) merkt voortreffelijk op : „Und noch später - hat er jene Ehestandscene nicht vergessen, aber der lockende Genuss wiegt dem losen Vogel etwaigen neuen Verdruss auf". Protinus (425) neemt hij de gestaite en kleeding aan van Diana, de maagdelijke meesteres van Callisto (een perfiede vermomming), en hiermede begint een comedy of errors, die Ovidius' talent alle eer andoet. Callisto begroet haar vermeende meesteres met 'salve numen, me iudice -, audiat ipse licet, maius Iove (428 v.): comische ironie. De belager lacht en sibi praeferri se gaudet (430). De kussen, die hij haar geeft, worden fijntjes gekwalificeerd als 
nec moderata satis nec sic a virgine danda (431; vergelijk onder „Pomona"). Hiermede is echter ook het hek van den dam, want als zij zijn vraag wil beantwoorden, neemt hij haar zonder meer in zijn armen, nec se sine crimine prodit (433). De worsteling, die volgt, wordt niet beschreven; Ovidius gaat veel fijner te werk, en wel door een pikant raisonnement : sed quèm superare puélla, Quisve Ióvem poterat (436 v.). En als Juppiter weer ten hemel vaart, wordt hij, victor (437) genoemd. Wat wij ons bij dit woord te denken hebben, leert een passage uit de Amores (de dichter heeft zich in onbesuisde woede aan zijn lief vergrepen) : $i$ nunc, magnificos victor molire triumphos, Cinge comam lauro votaque redde Iovi, Quaeque tuos currus comitatus turba sequetur, Clamet io! fórti victa puélla viro!" (1.7.35/8). Door Juno te apostropheeren (adspiceres utinam, Saturnia, mitior esses, (435) herinnert de dichter andermaal aan Juno, die Juppiter's werken der liefde aan het slachtoffer zal vergelden met haar werken der wraak. Deze scene eindigt met een beteuterde Callisto, die bijna vergeet pijl en boog mede te nemen.

In de volgende scene ontmoet het slachtoffer de heusche Diana. Als deze haar roept, gaat zij ijlings aan den haal, beducht, ne Iuppiter esset in illa (444). Eerst als zij bemerkt, dat de escorteerende nymphen ongemoeid blijven, durft zij te naderen! Deerlijk moeten het daarop Diana en haar nymphen ontgelden. Want al kon men aan duizend dingen merken, dat Callisto iets op haar geweten had, Diana, de maagdelijke, merkte niets : hopeloos onnoozel. Niet aldus de nymphen : zìj merkten het wél : et, nisi quod virgo est, poterat sentire Diana Mille notis culpam; - nymphae sensisse feruntur (451 v.). De verlichte dichter neemt een loopje met de onschuld, voorzoover er onschuld bestaat.

Kostelijk is ook de scene, waarin Callisto's zwangerschap ontdekt wordt, maanden later, als Diana en gevolg een bad nemen. Onafwendbaar, stap voor stap, komt de ondergang nader. Met berekende retardatie (evenals in "Actaeon" en "Arethusa") schildert de dichter de idyllische aanleiding, dan volgt, snel als een waterval, de dramatische ontknooping : eerst prijst de godin de omgeving van den stroom, dan voelt zij het water met een voet aan; daarop prijst zij oolk het water; tenslotte wordt het teeken tot ontkleeden gegeven; - tegenstribbelen van Callisto, gedwongen ontkleeding, ontdekking, verstooting.

Ovidius heeft de mogelijkheden, die Juppiter's vermomming biedt, fijn-comisch uitgebuit. $\mathrm{Nu}$ is, in feite, de Diana-vermomming de vondst van een comediedichter : Amphis (midden comedie). Men neemt aan, dat Ovidius diens vondst slechts middels alexandrijnsche verhalen kende, zoodat het comisch karakter van Ovidius' vertelling niet aan directe navolging van Amphis te danken zou zijn. Hoe dit ook zij, Ovidius steekt als comisch verteller gunstig af tegen den comicus Amphis. Diens pointe, dat namelijk Callisto haar zwangerschap Diana recht in haar gezicht verwijt (Kock II p. 249, fr. 47), is plat en goedkoop. Ovidius daarentegen, nimmer vulgair, staat boven zijn stof, zooals hij bij de worsteling van Juppiter en Callisto bewijst: de schrik van het slachtoffer, als zij Diana ziet, en haar angst voor nieuwe list, haar herademen, wanneer zij bemerkt, dat de escorteerende nymphen niet gemolesteerd worden en er dus geen gevaar dreigt, de onnoozelheid van Diana en de verlichtheid der nymphen, 
dat is een fijn, een comisch uitbuiten der situatie. Men mag de vraag stellen, of dit alles reeds zoo fijn, levendig en puntig voorkwam bij zijn eventueel alexandrijnsch voorbeeld.

Met de geboorte van het kind komt Juno in actie. Kort en hevig, op haar bekende matelooze wijze, vaart żij uit tegen de ongelukkige, die in haar oogen geen slachtoffer is van force majeur, doch een paelex (469), een adultera (471), ingenomen met haar figuur (475). $\mathrm{Z}_{\mathrm{ij}}$ heeft een groot woord op de lippen, iniuria (472), spreekt van „mijn Juppiter” (473) en „onzen echtgenoot” (475), en is over de geboorte van het kind daarom zoo gebelgd, omdat daardoor Juppiter's dedecus testatum is (473). Daarom deinst zij, de magni matrona Tonantis (466), al te menschelijk, niet terug voor handtastelijkheden : zij verandert Callisto in een beerin, doch niet alvorens haar hoogsteigenhandig bij de haren gegrepen en op de grond geworpen te hebben; - nogal vulgair.

Er gaat achter deze. scene meer schuil dan een oppervlakkige lectuur zou doen vermoeden; zij is, in feite, een specimen van Ovidius' camouflagekunst. Juno's verschijnen op dit punt van het verhaal is de oorzaak van eenige wrijving. Het is voor haar, de alspiedende, niet waarschijnlijk, dat zij eerst zeer laat ten tooneele verschijnt. Hiervan was de dichter zich bewust, reden waarom hij begint met vast te stellen, dat zij (hoe kon het ook anders?) senserat olim (466). Doch waarom dan zoo lang getalmd? De dichter haast zich een verklaring te geven : zij had haar wraak uitgesteld in idonea tempora (467) : een gelegenheidsmotiveering, want het ligt niet in Juno's lijn, haar tijd te beiden : haar is de eerste gelegenheid de beste. Wil de dichter met causa morae nulla est (468) suggereeren, dat het uitstel verband houdt met de omstandigheid, dat Diana nog onkundig was? Doch ook dit kan de situatie niet redden, want, gesteld al, dat Diana's gunst voor Juno's wraak een beletsel zou zijn, Diana had gemakkelijk ingelicht kunnen worden; het veronderstelt een hemelsch geduld, zooals de hemelkoningin dat niet pleegt te hebben, te wachten, tot de onnoozele in de negende maand de oogen open gaan. Bovendien verloopt er althans eenige tijd tusschen de verstooting en het baren. Ovidius glijdt over dit netelig punt in zijn verhaal snel heen met enkele opmerkingen, die schijnbaar een verklaring geven, en haast zich met een luchtig et iam (468) naar het oogenblik van Arcas' geboorte: hier heeft hij namelijk een opwindend moment, zeer geschikt om Juno in actie te laten komen. Aldus terecht $\mathrm{H}$ e in ze (p. 107), die hieraan echter een tweede reden voor het uitstel van Juno's wraak vastknoopt, welke meer getuigt van een zeker soort van eigen fijngevoeligheid dan van kennis van Ovidius: Ovidius ,erspart zudem sich und dem Leser die fabelhafte Tatsache, an der ältere Dichtung keinen Anstoss genommen hatte, dass die Bärin ein Menschenkind zur Welt bringt". Dit is zeker niet het geval; men vergelijke slechts, hoe in boek X $(503 / 10)$ in alle uitvoerigheid de barensweeën beschreven worden van den boom, die eens Myrrha was, waaruit een krijtende knaap wordt geboren. De verklaring ligt enkel in het opwindend moment. Ovidius laat Juno zich opwinden over Juppiter's publieke schande, waarmede hij onze gedachten afleidt van het moeilijke punt, het uitstel der wrake. Want het is niet zoo, dat Ovidius de wraak uitstelt, om Juno over de vruchtbaarheid der paelex 
en vooral over schande van haar Juppiter te laten fulmineeren ; doch, omdat de dichter haar wraak had uitgesteld (hetgeen voor een Juno niet erg plausibel klonk), laat hij haar dermate vuur spuwen over vruchtbaarheid en schande. Zou men Juno's woorden mogen gelooven, dan was het gebeurde met Callisto een exceptioneel geval ; wij weten echter maar al te goed, hoe door zijn erotische activiteit (zie totiens en saepe in "Io" en "Echo") en zijn tallooze bastaarden (zie onder "Peleus et Thetis") Iuppiter infamat seque suamque domum (Prop. 3. 11. 38). De reden, dat Juno in actie komt bij Arcas' geboorte, is, dat hier een opwindend moment is ; doch wat was de reden van het uitstel ? Mijns inziens deze, dat Ovidius de dankbare scene van het bad en de ontdekking niet wilde missen, - een scene, die, als wij $\mathrm{He}$ in ze (p. 109 v.) mogen gelooven, enkel bij Ovidius voorkomt. $\mathrm{Hij}$ had alle moeilijkheden kunnen vermijden door het voor te stellen, alsof Juno eerst bij Arcas' geboorte Juppiter's nieuwste echtbreuk ervoer. Deze oplossing wees hij echter van de hand, omdat dit niet strookte met

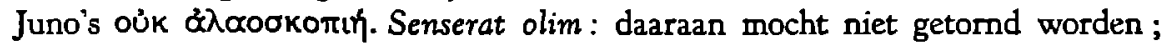
liever accepteerde hij eenige wrijving. Met zijn bekende vindingrijkheid en luchthartigheid (zie ook onder „Herse" en "Caesaris apotheosis") verdoezelde hij, door enkele gelegenheidsmotiveeringen, de oneffenheid; en vervolgens laat hij Juno heftig en vermakelijk schande spreken en haar waardigheid te grabbel gooien. Alles gaat zoo snel in zijn werk, en wordt zoo smakelijk voorgesteld, dat de goede lezer geen tijd krijgt voor critische bezinning: het geheugen bedwelmend, prikkelt Ovidius de fantasie, en de lapmiddelen worden weer voortreffelijkheden; want de geboorte van Arcas verklaart Juno's acute woede, haar acute woede verklaart weer haar felle wraak.

Als Callisto, de beerin, door Juppiter als gesternte aan den hemel is geplaatst, zoekt Juno in hoogste opwinding Oceanus en Tethys op, en weet te bewerken, dat het gehate gesternte niet in den Oceaan mag onderduiken. Volgens $\mathrm{E} h \mathrm{w}$ a ld (ad 508) misschien, volgens Peters (p. 58) zeker, heeft Ovidius deze scene zelf verzonnen, en wel door combinatie van Hera's befaamde leugen over een bezoek aan Oceanus en Tethys in Ilias XIV (200 vv.) en een astronomische opmerking van Homerus over het Beerengesternte (XVIII 489). Volgens Heinze, die evenwel geen redenen opgeeft, is deze scene stellig Hellenistisch. He in ze heeft waarschijnlijk gelijk. Zoowel de wrokkende Juno als het Beerengesternte mogen zich in de belangstelling der Alexandrijnen verheugen. Er zijn nog twee andere passages, waar Ovidius gebruik heeft gemaakt van het feit, dat dit gesternte aequoris expers (13.727) is en waar men aan alexandrijnschen invloed gedacht heeft. Daar is in de eerste plaats de Fasti-versie van den Roof van Proserpina, waarin als getuige van den nacht de Maangodin uit de Homerische Demeterhymne vervangen is door het Beerengesternte; reden : dit gesternte, dat nooit ondergaat, kan, in tegenstelling tot de maan, die aan perioden gebonden is, met zekerheid inlichtingen verschaffen over het nachtelijk gebeuren : liquidique inmunia ponti; aequoreas numquam cum subeatis aquas (4.575; 578). Volgens $\mathrm{M}$ alten (p. 519) is deze innovatie van alexandrijnsche herkomst. Vervolgens, bij den wereldbrand in "Phaethon" tracht de Groote Beer vergeefs in het "verboden" water van den Oceaan onder te duiken (2.171 v.). Volgens 
Nonnus (38. 408 v.) gebeurde dit uitzonderlijke wel. Volgens $\mathrm{Kna} \mathrm{a} \mathrm{ck} \mathrm{(p.} \mathrm{40)}$ gaat dit motief, zoowel door Ovidius als Nonnus gebruikt, op hun gemeenschappelijk alexandrijnsch voorbeeld terug. Dit laatste laat ik in het midden (zie onder „Phaethon"); wel zou ik erop willen wijzen, dat Ovidius van de sterrebeelden enkel Beer, Slang en Bootes vermeldt, en dat deze trias meerdere malen door Nonnus als een samenhangende groep wordt genoemd $(1.252 / 4 ; 2.183 \mathrm{v}$.; $5.122 ; 33.375)$. Toevallig is deze selectie van Ovidius niet; of zij hem door een alexandrijnsche bron is ingegeven, dan wel dat zij op eigen astronomische kennis berust, waag ik niet te beslissen. - Wij hebben hier dus twee passages, waarin, onder min of meer alexandrijnsche omstandigheden, Ovidius speelt met het Beerengesternte aequoris expers. Men kan verder wijzen op Aratus' Phaenomena

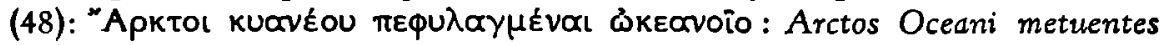
aequore tingui (Verg. G. 1. 246). Het is daarom in "Callisto" niet noodig een beroep te doen op de astronomische notitie van Homerus om Ovidius' astronomische kennis omtrent het Beerengesternte te verklaren. Daarentegen zou het geheel in de lijn der verwachting liggen, als een alexandrijn, met gebruikmaking van een Homerisch motief, de wrok van Juno en haar bezoek aan Oceanus en Tethys benutte om een bekend astronomisch feit te "verklaren". Ovidius is stellig zelfstandig genoeg om gegevens op eigen gezag te combineeren; doch hier is het niet waarschijnlijk, dat hij als eerste deze combinatie maakte.

Merkwaardiger is nog, dat wij voor Juno's ontboezeming bij Ovidius treffende parallellen vinden in Nonnus' verhaal van Semele. Daar wenscht Hera den gordel van Apate te leenen. Het behoeft geen betoog, dat Nonnus hierbij

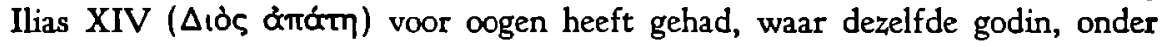
het voorwendsel, dat zij Oceanus en Tethys wil verzoenen, Aphrodite's gordel leent. De Hera van Nonnus spreekt de vrees uit, dat zij uit den hemel verdreven en onttroond zal worden en Semele tot koningin des hemels verheven (8.150/61). Deze gedachte weet zij aannemelijk te maken door de volgende redeneering: bij zijn overige avonturen vereerde Zeus zijn liefjes slechts één enkele maal met een bezoek (Danae, Europa) om haar daarna aan haar lot over te laten (Io, en zelfs de godin Leto); Semele evenwel bezoekt hij telkens weer. Verder zegt Hera nog tot Apate : mocht zij er niet in slagen, om Ares, die mokkend den Olympus verlaten heeft, te bewegen om naar den hemel terug te keeren, dan zal zij zich, in vrijwillige ballingschap, naar Oceanus begeven en bij Tethys verblijven. (Tevoren had Phthonos, vermomd als Ares, Hera met bittere sarcasmen tegen Semele opgezet : hij gaat den hemel verlaten, daar deze vol is van Zeus' aardsche liefjes; de hemel is de woonplaats van stervelingen geworden ; allerwegen komt men een Callisto of een Electra tegen, 8.71/7.) - Hiermede vergelijke men verschillende motieven van Juno bij Ovidius. $Z_{i j}$ oppert de mogelijkheid eener verstooting : cur non et pulsa ducit Iunone meoque Collocat in thalamo socerumque Lycaona sumit? $(525 \mathrm{v}$.). Verder vinden wij het motief der vrijwillige ballingschap ook bij Ovidius : 'quaeritis, aetheriis quare regina deorum Sedibus hic adsum? pro me tenet altera caelum !' (512 v.). Juno slaat weer op haar gebruikelijke wijze door (paelex, 530, is haar laatste woord; de hemel is volgens haar voor Callisto stupri merces, 529). Wat in Nonnus' "Semele" een 
schijn van redelijkheid heeft, is in Ovidius" "Callisto" schromelijke overdrijving en zotte woordspeling. Het zou evenwel interessant zijn nauwkeurig te weten, welke precies de verhouding is tusschen Nonnus en Ovidius, of en in hoeverre beiden zelfstandig te werk gaan, of Nonnus van Ovidius gebruik gemaakt heeft, of en in hoeverre beiden (bij Nonnus is stellig ook directe invloed van Homerus aanwezig) van gemeenschappelijke alexandrijnsche voorgangers gebruik gemaakt hebben en wat eventueel het onderwerp was van hun voorbeelden. Juist het schemerduister is verlokkend, en daarom is de uiterste behoedzaamheid geboden.

Juno's ontboezemingen winnen verder nog aan vermakelijkheid, doordat zij ons gedurig herinneren aan haar pathetische monologen in Vergilius' Aeneis. Aan Vergilius' absumptae in Teucros vires caelique marisque. 2uid Syrtes aut Scylla mihi, quid vasta Charybdis Profuit? optato conduntur Thybridis alveo, Securi pelagi atque mei - Ast ego, magna Iovis coniunx, nil linquere inausum 2 uae potui infelix, quae memet in omnia verti, Vincor ab Aenea $(7.301 / 4 ; 308 / 10)-$ herinnert Ovidius' o ego quantum egi! quae vasta potentia nostra est! Esse hominem vetui : facta est dea! sic ego poenas Sontibus inpono, sic est mea magna potestas! $(520 \mathrm{vv})$. Hieraan vooraf gaan verzen, waarin Ovidius een vraag aan Juno uit Aeneis I persifleert. Bij Vergilius zegt de godin : et quisquam numen Iunonis adorat Praeterea aut supplex aris inponet honores? (48 v.). Bij Ovidius heet het: et vero quisquam Iunonem laedere nolet Offensamque tremat, quae prosum sola nocendo? (518 v.; vergelijk onder "Semele"). En waarom gaat het dan eigenlijk ? In de Aeneis om niets minder dan het falen harer wereldpolitiek, in de Metamorphosen om een furtum (vergelijk onder „Ino"). Bij den eersten dichter raakt het haar goddelijke macht (adorare), bij den tweeden haar eer als matrone (laedere; zie ook onder "Io"): de mug wordt een olifant. Zoo weet Ovidius zijn verhalen te kruiden ook met zinspelingen op de eigen Romeinsche dichters.

Dit verhaal wordt dus gekenmerkt door vermenschelijking en fijne, soms exuberante en satirische ironie.

\section{CORONIS (II 542-632)}

Ovidius heeft van dit verhaal een soort elegie-intrigue gemaakt naar het Rome van zijn eigen tijd.

Heeft het er aanvankelijk den schijn van, dat ons een rustig, onoverhaast ontwikkeld verhaal zal worden voorgezet, beginnend met de van ouds bekende schoonheid der heldin (pulchrior in tota quam Larissaea Coronis Non fuit Haemonia, 542 v.), een oogenblik later worden wij, door een formeele restrictie (alsof Apollo geen kenner ware!) en een levendige apostrophe (placuit tibi, Delphice, certe, 543), in medias res verplaatst : reeds is de raaf op weg naar zijn heer om haar ontrouw te melden; de groei van de verhouding te schilderen zou op den duur vermoeien en Ovidius' bedoeling met dit verhaal noodeloos ophouden. Wij maken terstond kennis met de hoofdpersonen, Coronis, Apollo en de raaf. Vel casta vel inobservata (544) wordt de beminde genoemd, een meesterstukje van Ovidiaansche suggestie, dat de opvattingen van het moderne Rome, in de Ars Amatoria en de Amores weerspiegeld, treffend formuleert. 
Een vrouw immers, evenals een man, behoeft zich in de liefde niet te beperken tot één partner; het zou even benepen zijn, trouw te eischen, als naief, aan trouw te gelooven; in Rome althans is trouw ondenkbaar. In tegenstelling tot de officieele censuur, veroordeelt censor Ovidius de mannen niet tot één meisje ; men flirte vrij, doch voor de oogen der wereld modest, zonder zich op zijn zonden te beroemen (Ars 2.387/90). De dichter is niet zoo benepen, van zijn lief trouw te eischen, daar zij nu eenmaal knap is (cum sis formosa); zij zorge enkel, dat hij haar ontrouw niet behoeft te bemerken; hij zal geen nazoekingen doen; om den tuin geleid te worden, is hem een weldaad (Am. 3.14.1 v. en 41 v.). Vel casta vel inobservata weze een vrouw; dit is de bevredigende formule, sceptisch genoeg om niet naief, ruimhartig genoeg om niet benepen te zijn; zij bestendigt het schemerdonker en laat de zaak onbeslist. En in het geval van Coronis is de ontrouw latent (latentem, 545, niet zonder reden aan het verseinde), zoodat er geen reden was tot ontevredenheid en klikken. Bij Hesiodus (fr. $123 \mathrm{Rz}$.) viert zij bruiloft met den mededinger; Pindarus (Pyth. 3. 14), om de schuld van het paar grooter en Apollo's wrake dwingender te maken, maakt hiervan een zondige, heimelijke verhouding; ook bij Callimachus (Hecale, fr. $64 \mathrm{~K}$.) is er sprake van $\mu \mathrm{l}$ póv $\tau \mathrm{\tau}$; bij Ovidius echter is het een decent furtum. De raaf is echter een klikspaan, die niet wijselijk verzwijgt, wat, verborgen, niemand deert. Geen vir heeft wakkerder custos voor zijn puella. Voor den raaf is het een zwaarwegend geval van adulterium (545), een woord, dat, in verband met index (546; ostentatief aan het verseinde), juridische associaties opwekt. Hoeveel pikante zinspelingen op en polemische spot tegen de leges Iuliae de adulteriis in de Amores, Heroides en Ars te vinden zijn, heeft Pok rowskij aangetoond. In een voetnoot (p. 367 n. 8) wijst hij op enkele gevallen van verachting der denuntiatie in de Metamorphosen. Van de drie door hem genoemde gevallen heeft slechts het eerste (4.190: Mars en Venus) betrekking op een geheime, overspelige liefdesverhouding. In het tweede $(5.542,551)$ is in het geheel niet van overspel sprake. In het derde (15.503 : Phaedra en Hippolytus) wordt de mogelijkheid geopperd van het aanbrengen van een poging tot overspel ; dit zou dan echter niet geschieden door een derde persoon, doch door een der betrokkenen zelf. Tot zoover over de voorbeelden van Pokrowskij zelf. Het is te betreuren, dat deze juist de opmerkelijke gevallen onvermeld liet, te weten het indicium van den raaf, dat van Clytie in "Leucothoe", en de ondeugende zinspelingen erop in "Cephalus en Procris". In "Leucothoe" licht Clytie den vader van haar rivale verraderlijk in over de verhouding tusschen Sol en zijn dochter (4.234/7); de wijze, waarop dit verteld wordt, het berekend rythme der verzen, de emphase, waarmede een en ander onder onze aandacht gebracht wordt, herinneringen aan het geval van den raaf. In "Cephalus en Procris" zijn opvattingen en toestanden hoogst modern. Door de sluwe suggesties der afgewezen Aurora (die in arglistigheid niet onderdoet voor eenige teleurgestelde puella uit Rome !) overweegt Cephalus de mogelijkheid van ontrouw zijner vrouw : facies aetasque iubebant Credere adulterium (7.716 v.); want, om met de Amores te spreken, est etiam facies, sunt apti lusibus anni : Indigna est pigro forma perire situ (2.3.13 v.). Hij neemt, vermomd, de proef ; aan- 
vankelijk zonder succes, zelfs als hij (als de dives amator der elegie) belooft census dare pro nocte (739); doch door zijn aanbod steeds te vergrooten, brengt hij haar trouw aan het wankelen; doch op dat oogenblik roept hij uit : adest male fictus adulter, Verus eram coniunx; me, perfida, teste teneris (741 v.). Een merkwaardig geval van adulterium! Op den juridischen zin van testis en tenere wijst $\mathrm{E} \mathrm{h}$ wald t.p. Criminis (extemplo) ficti temerarius index $(824$; een vol vers, niet zonder emphase) licht later Procris in omtrent Cephalus' vermeende flirtations met een vermeende Aura. Smartelijk getroffen, weigert zij toch, in vlagen van critischen zin, het te gelooven : indicioque fidem negat et, nisi viderit ipsa, Damnatura sui non est delicta mariti (833 v.). Hoe redelijk en onschuldig het ook klinkt, het herinnert niettemin sterk aan het argument der laksche echtelieden ,nec vidi nec credo", waarmede volgens de letter der wet de zin der wet ontdoken werd. Het verhaal van Cephalus en Procris is tegen het indicium en de noodlottige gevolgen ervan gericht; evenzoo het verhaal van Coronis. Beiden raken een actueel probleem aan. Non exorabilis wordt de klikker nog genoemd, hetgeen zijn rigide benepenheid nog onderstreept, die ook in de volgende ontmoeting met de kraai aan het licht treedt. Teekenend zijn de woorden, waarmede hij zijn heer van het gebeurde verwittigt : iacentem (duidelijk genoeg ! zie ook onder „Echo”) Cum iuvene Haemonio vidisse Coronida (598 v.). Opmerkelijk is vooral het vage iuvene Haemonio, want het lijdt geen twijfel, of Ovidius kende den naam van dezen jongen man : niet alleen Hesiodus en Pindarus, doch ook Callimachus, en wel in de vermaarde „Hecale”, geven den naam : Ischys. Ovidius verkiest echter de onbestemdheid, die satirisch de klikzucht van den custos aan de kaak stelt : „een Thessalische jonge man"; hij heeft in zijn overijldheid geen tijd gehad, de raaf, om nadere gegevens te verzamelen. Apollo is de vir credulus der elegie en wordt aan den lachlust prijsgegeven : laurea delapsa est audito crimine amantis, $E$ t pariter vultusque deo plectrumque colorque Excidit (600 vv.). Apollo staat hier op gelijke lijn met Vulcanus, wiens stumperigheid in den minnehandel notorisch is (,Mars en Venus"): at illi $E t$ mens et quod opus fabrilis dextra tenebat Excidit ( $4.175 \mathrm{vv}$.). In beide gevallen verhoogt het zeugma het comisch effect. Apollo is bovendien des te lachwekkender, omdat de dichter, door het vermelden van lauwerkrans en plectrum (dus ook cithara) den lezer het beroemde beeld voor den geest haalt van den majesteitelijken Apollo in zijn Palatijnschen tempel (zie onder "Midas"). In onbesuisde woede schiet de bedrogene het meisje neer, om dra spijt te hebben van zijn onherstelbare daad. Hierin steekt de moraal voor de Romeinsche jongelingschap: wraak, aan de geliefde bedreven wegens een onbeduidend furtum, is verfoeilijk en straft zich meestens zelf. De ommekeer in het verhaal wordt door een elegische noot en het rythme geaccentueerd : et illa suo totiens cum pectore iuncta In-de-vi-ta-to tra-ie-cit pectora telo (604 v.). Met veel liefde wordt de ongelukkige in haar laatste momenten geteekend. Voor Apollo geldt: paenitet heu! (612). Hij verwenscht - te laat - zichzelf, zijn pijlen, en den vogel, per quam crimen causamque dolendi $S$ cire coactus erat (614 v.). De raaf wordt gestraft, al verwacht hij het tegendeel (in sperantemque sibi non falsae praemia linguae, 631, hoort men zijn verwondering): hij wordt gestooten 
uit de vergadering der witte vogelen; consistere is, naar $\mathrm{Ehwald}$ ad 632 opmerkt, terminus technicus van het vergaderen van de leden van een college. Aldus gaat aan dezen dommen custos in vervulling, wat Ovidius in de Amores aan den custos van zijn lief voorhoudt : dwaze onkreukbaarheid is het, den heer over kleine furta in te lichten :

vidi ego compedibus liventia crura gerentem, 2.2.47

unde vir incestum scire coactus erat;

poena minor merito: nocuit mala lingua duobus;

vir doluit, famae damna puella tulit.

crede mihi, nulli sunt crimina grata marito,

nec quemquam, quamvis audiat, illa iuvant.

Vergelijk ook nog : sed ne sit misero scire necesse mihi (Am. 3. 14.2).

Dit verhaal wordt dus gekenmerkt door gedurfde moderniseering, vermenschelijking en ironie.

\section{ADMETUS ET BATTUS (II 676-707)}

Reeds Nicander (bij Anton. Liber. 23 ; E h wald ad 676/707) had de bekende runderdiefstal van Mercurius in verband gebracht met Apollo's verliefdheid; in plaats van den bekenden Admetus had echter deze geleerde dichter een variant ontdekt : Hymenaeus; Ovidius herstelt hier Admetus, een van Apollo's vermaardste liefdes, in zijn oude heerschappij (Di i tze p. 32). Apollo's verliefdheid op Admetus doet dienst als verbindingsschakel tusschen "Ocyroe" en „Battus". De wijze, waarop Ovidius zich van dit motief bedient, getuigt van groote ingeniositeit en zelfstandigheid. Chiron smeekt Apollo om hulp, vergeefs, daar de god niet te Delphi vertoeft, doch elders : hij is verliefd. Dat een verliefde god zijn goddelijke, zijn officieele werkzaamheden, en zijn cultusplaatsen verwaarloost, is hoogstwaarschijnlijk een alexandrijnsch motief. In de Metamorphosen vinden wij het nog in "Hyacinthus" en "Adonis". Wij vinden het ook in een zeer levendige, uitvoerige passage, die Tibullus wijdt aan Apollo, verliefd op Admetus (2.3.21 v., 27 v.), waarbij Tibullus wel van alexandrijnsche bronnen gebruik maakt, evenals in zijn Priapuselegie (zie onder „Hyacinthus”). Ovidius nu maakt van dit motief niet mechanisch gebruik, doch om den overgang tot stand te brengen van het eene verhaal naar het andere. In de daarop volgende verzen wordt Apollo's uiterlijk geschilderd : kleeding, staf en fluit teekenen hem als herder : hij is geheel mensch onder menschen geworden. Met illud erat tempus, quo te etc. (680) verwijst Ovidius wel naar bekende motieven; men kan aan Tibullus' verzen denken, mogelijk is het een verwijzing naar Nicander. Volgens Grimal (p. 146) laat deze evocatie van Apollo Herder, „étrangement précise”, zich nauwelijks anders verklaren dan als een zinspeling op zulk een kunstwerk. Het een sluit het ander niet uit. De apostrophe verhoogt nog de ironie der situatie en het contrast met het volgende verhaal. Want terwijl Apollo, aan het aardsche gewoel ontrukt, droomerig zit te pijpen (bekend motief : Tibull. 2.3.19 v.; Lygdam. 4. 71), ontfutselt hem Maia's gewiekste zoon de onbewaakte kudde. 
In "Battus, of de bedrieger bedrogen”, een korte humoristische novelle, is de meesterdief Mercurius de hoofdpersoon. Dat deze patroon der perfiditeit prikkelend werkt op Ovidius' gevoel voor ironie, bewijst het satirisch gebed van den koopman in de Fasti, dat aldus besloten wordt : talia Mercurius poscentes ridet $a b$ alto, Se memor Ortygias surripuisse boves (5.691 v. ; $\mathrm{R} \mathrm{ib} \mathrm{beck} \mathrm{p.} \mathrm{281).}$ De guitigheid en het raffinement van deze novelle is met geen pen te beschrijven; slechts mimiek en stemmodulatie kunnen haar recht doen wedervaren. Woorden en gebaren van god en tegenspeler, twee "jongens van de vlakte", worden levendig beschreven; de huppelende verzen, de korte zinnetjes, de berekende woordherhalingen geven aan deze stof den idealen vorm. Een vergelijking met Nicander's verloren versie zou Ovidius' meesterschap eerst recht laten uitkomen.

Dit verhaal wordt dus gekenmerkt door vermenschelijking en speelsche ironie

\section{HERSE (II 708-832)}

Het schijnt, dat Ovidius dit verhaal op grond van slechts enkele gegevens (zie Ehwald ad 708) zelfstandig heeft ontwikkeld. Hij heeft er een sterk alexandrijnsch karakter aan gegeven.

Wanneer Mercurius, na zijn avontuur met Battus, hemelwaarts vliegt, wordt boven Attica zijn oog getroffen door de Atheensche schoonen, die juist terug. keeren van een processie ter eere van Pallas. Terwijl hij met begeerig welgevallen rondcirkelt, ontvlamt hij in liefde tot de schoonste der schoonen. $\mathrm{Z}_{\mathrm{ijn}}$ keus is gemaakt; en hij daalt, om avances te maken, naar de aarde af. $\mathrm{Ehwald}$ (ad 711) wijst erop, dat het een alexandrijnsch motief is, verliefd te worden op een feest. De jongelingschap, zoo beweert Musaeus (Hero en Leander 51/4), reflecteerend op dit motief, stroomt, waar sprake is van feest, samen, niet zoozeer

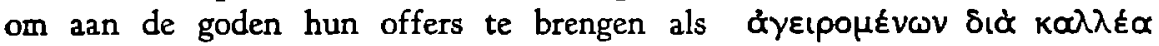
$\pi \alpha p \theta e v$ ckówv. Ovidius had dit motief reeds in de Ars verwerkt. Het eerste deel hiervan is gewijd aan het vinden van een lief; de ervaren minnaar moet zijn plaatsen weten te kiezen : ante frequens quo sit disce puella loco (1.50). Het zijn de gaanderijen, de tempels, de fora, de theaters, het circus en andere feestelijke gelegenheden. Zoo hij deze slechts frequenteert, zal hij zonder twijfel iets van zijn gading vinden : quodque semel tangas, quodque tenere velis (92). Mercurius is van plan de gelegenheid te benutten voor het eerste, „to pick a damsel" ( $R$ and p. 62). Daarbij wordt onze $\pi \alpha p \theta \varepsilon v o \pi(\pi \eta \varsigma s$ met weinig eerbied behandeld. Zooals anderen flaneeren over de pleinen, zoo cirkelt hij rond in de lucht; hij kent zijn ars amandi. Daarbij wordt tweemaal in twee opeen. volgende verzen het woord avidus gebruikt (719 v.). Treffend wordt zijn gedrag, in "not a reverent comparison" ( $R$ a nd p. 62), vergeleken met dat van den roofvogel, die op de gelegenheid aast om zich te goed te doen aan de offergaven des altaars.

Mercurius neemt geen vermomming aan. Omdat de stervelingen den aanblik der onverhulde godheid niet konden verdragen, naderden de goden, volgens de oude opvattingen, de menschen, ook de begeerde schoonen, in een vermomming. De verklaring der ouden verontachtzamend (niet uit onwetendheid, zooals 
Peters p 76 meent, doch om een pikant effect te beresken), namen de Alexandrunen het feit der vermomming over, die onder hun handen tot een middel werd om zich van de geliefde meester te maken; vandaar ook dat, eenmaal het doel bereikt, de vermomming, die haar werk had gedaan, werd afgelegd. Mercurius echter, de bode der goden en intermediarr tusschen hemel en aarde, behoefde z,ich niet te vermommen. Mercunus' utzonderlyke positie was aan Ovidius bekend, die dan ook het ontbreken der vermomming, ut tal van verhalen welbekend, uitdrukkelijk vermeldt, doch met welk een verklaring: nec se dissimulat. tanta est fiducia formae (731). (Mercunus is inderdaad een knappe jongeman : et crins flavos et membra decora iuventa, Verg Aen. 4559 ) $\mathrm{Nu}$ had Ovidius in de Ars zijn discipelen voorgehouden : munditie placeant:(1. 513) sit bene convemens et sine labe toga, (514) - nec vagus in laxa pes trbi pelle natet, Nec male deformet ngtdos tonsura capillos. Sit coma, sit scita barba resecta manu etc (516 vv). Mercunus neemt deze vermaning ter harte, en "macht erst sorgfaltig Toulette" (R 1 b be ck p 302), „prend de sa toilette le soin qu'y apporterait un petit-maître ( $\mathrm{L}$ a m a r r e p 190), „comme un jeune élégant" (P1ch on P 422), "plane ut luvenis elegans Romanus" (Peters p. 80 n. 1). (Ook Ehwald ad 731 verwyst naar de Ars. Heinze rept over dit verhaal met geen woord.)

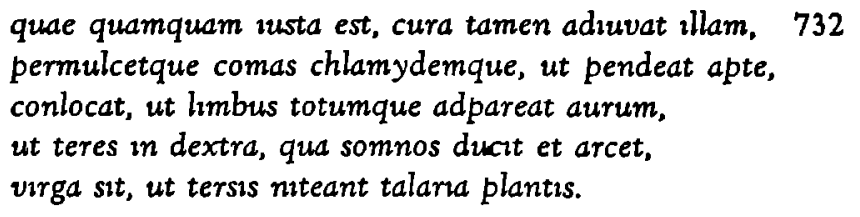

De uitvoering der voorschriften is aan plaats en persoon aangepast: vandaar chlamys (Attica), caduceus en vleugelschoenen (attributen van Mercunus) Uit de uitvoenge beschrijving blykt, dat Ovidius Mercunus wil schilderen in dit verhaal als een held uit de wereld der elegie $\mathrm{H}_{1}$ gaat echter nog verder. Mercunus wordt onderschept door Aglauros, een zuster der beminde $O_{p}$ haar vragen geeft hij alle gewenschte inlichtingen omtrent naam, kwaliteit en doel der visite, en vraagt vnendelyk om haar gewaardeerde medewerking. Deze echter, onbewogen, vraagt van den dives amator een aanzienlujk dienstgeld en verwijst hem tot zoolang naar de deur, onvermurwbaar.

proque ministeno magni sibi pondens aurum 750

postulat, interea tectis excedere cogit -

denique in adverso venientem limine sedit 814

exclusura deum, cur blandimenta precesque

verbaque ractanti mitissima -

Ovidius geeft in de Ars den raad, om door vnendelykheld haar omgeving voor zich te winnen en zich hiervoor kleine vernederingen te getroosten :

nec pudor ancillas, ut quaeque ent ordine prima, 2.251 nec tibn sit servos demerutsse pudor.

nomine quemque suo (nulla est ractura) saluta, runge turs humlles, ambitiose, manus. 
fac plebem, mihi crede, tuam: sit semper in illa 259 ianitor et thalami qui iacet ante fores.

Ook Ehwald (ad 750) verwijst naar de Ars, doch eenigszins ongelukkig naar 1.351 vv., waar de ancilla geschilderd wordt als pleitbezorgster des minnaars. Mercurius volgt den raad der Ars, doch het vergaat hem niet beter dan zijn aardsche lotgenooten, die verzuchten: aured sunt vere nunc saecula (2.277). Aglauros, de koningsdochter, wordt door Ovidius, om de overeenkomsten met de wereld der elegie nog te vergrooten, voorgesteld als de inhalige lena of of, liever nog, als een dier andere plagen, de plukkende zuster (et soror et mater, nutrix quoque carpat amantem, Am. 1.8.91), en herinnert aan thalami qui iacet ante fores.

Wij hebben dus te doen met een verregaande moderniseering. Mercurius wordt geschilderd als de held van een moderne elegie-intrigue. Hierbij sluiten enkele andere anachronismen en moderniseeringen wel aan. Op mythische tijden draagt Ovidius over, het Lyceum (cultique arbusta Lycei, 710) en de geestescultuur (ingeniis opibusque virentem, 795) van het historische Athene (E h w a ld 710.795). Verder horen wij van de luxueuze uitvoering der slaapkamers der Cecropiden (ebore et testudine cultos, 737): „Het gebruik dezer kostbare stoffen is overeenkomstig de woningluxe van Ovidius' tijd" ( $\mathrm{Ehwald}$ ad 737).

Aglauros behoort natuurlijk gestraft te worden; haar afwijzing van den god uit hebzucht vraagt hierom. Ovidius heeft hier echter nog bijgevoegd haar afgunst op het geluk harer zuster. Deze afgunst werd haar overgezonden door Pallas. Pallas heeft een gerechtvaardigde grief tegen Aglauros: deze heeft de klow geopend, waarin Erichthonius, de zoon van Hephaestus, lag, die door Pallas werd grootgebracht. Hierover had Callimachus in de "Hecale" gehandeld (zie fr. $60 \mathrm{Ka} \mathrm{P} \mathrm{p);} \mathrm{het} \mathrm{was} \mathrm{klaarblijkelijk} \mathrm{een} \mathrm{beroemde} \mathrm{geschiedenis,} \mathrm{wel} \mathrm{niet}$ in de laatste plaats omdat zij aangestipt was door den beroemden Callimachus in de beroemde Hecale; Nonnus verwijst er herhaaldelijk naar (bijv. 13. 172/9; $27.110 / 7$; 27.317/25; 29.335/9; 41.63 v.; 42.248/50; 48.411; 48.954/7). Ovidius maakt van Erichthonius nog gebruik in "Turbida Seditio" (zie daar). In de Tristia wijst hij er op, dat een perverse geest bij het aanschouwen van het beeld van Pallas zich kan afvragen, waarom de maagdelijke godin zich ontfermde over Erichthonius, die toch geboren is uit een crimen (2.293/4). Aan de bekende scene uit Callimachus' Hecale herinnert Ovidius dus zijn lezers, wanneer hij Pallas in dit verhaal betrekt. In de schildering van Pallas nu treft ons de vermenschelijking in enkele biotische trekjes: zoo zwaar zuchtte de verbolgene, dat de aegis op haar borst ervan schudde $(754 \mathrm{v}$.); verderop horen wij nog van de suspiria der godin (774). Het bevel, dat zij Invidia geeft, teekent haar intense haat tegen Aglauros (en tevens haar afkeer van de weerzinwekkende Invidia); staccato: 'infice tabe tua natarum Cecropis unam! Sic opus est. Aglauros ea est'. „Erst zuletzt gewinnt es die Göttin über sich, den Namen der verhassten Aglauros auszusprechen" (E h wa ld ad 785). Pallas' zeer menschelijke animositeit wordt ook in "Arachne" gelukkig geschilderd.

Wat de schildering van Invidia betreft, kunnen wij kort zijn. Het is apert, 
dat wij hier met een personificatie te doen hebben. Ovidius geeft hier een uitvoerige ekphrasis, de eerste eener reeks (vergelijk Fames in „Erysichthon”, Fama, Somnus in "Ceyx et Alcyone"). Alle details zijn afgestemd op het begrip invidia. De ingeniositeit des dichters viert hoogtij. Merkwaardig is het spel met de dupliciteit, dat ook aan deze soort personificaties bedreven wordt tot in de uiterste consequentie. Zooals Tellus-godin zich in zichzelf (tellus-aarde) terugtrekt, zoo speelt de dichter ook met Invidia-personificatie en invidia-eigenschap : carpitque et carpitur una Suppliciumque suum est (781/2). Als afgunst aan Afgunst knaagt, knaagt zij aan zichzelf. Iets dergelijks wordt ook van Fames en van Somnus gezegd.

Dit verhaal draagt dus, door zijn moderniseering, zijn vermenschelijking en het spel met de dupliciteit, een uitgesproken alexandrijnsch karakter. Verantwoordelijk daarvoor is niet een voorbeeld, doch Ovidius zelf. Deze stelt op zijn moderniseering van Mercurius eenerzijds, en zijn inlassching van de wraak van Pallas en van Invidia anderzijds zooveel prijs, dat hij er eenige wrijving in zijn verhaal voor over heeft. Dit zoowel als de luchthartige, doch tevens handige wijze van verdoezeling zijn kenmerkend voor Ovidius. Door Invidia's ingrijpen verdwijnt het motief der inhaligheid om plaats te maken voor dat der matelooze jaloerschheid. De ontwikkeling der gebeurtenissen, zoo klaar als zij eerst was, wordt door dit tweede motief verward. Het heet, dat Aglauros dag en nacht door afgunst verteerd wordt $(806 \mathrm{v}$.$) . Wat moeten wij ondertusschen$ aanvangen met den afgescheepten Mercurius! Het is immers onwaarschijnlijk, dat deze onstuimige minnaar, geducht door zijn tooverstaf, waarvan hij zoowel elders (zie "Chione") als ook later in dit verhaal gebruik maakt, met gebogen hoofd door Athene's straten zal dolen. De dichter verdoezelde de moeilijkheden, zooals gewoonlijk (zie bijv. "Callisto" en "Caesaris apotheosis"), zoo goed mogelijk, het geheugen bedwelmend, de fantasie prikkelend. Het idee van den gesoigneerden god, die afgewezen wordt, is zoo vermakelijk, dat de critische zin des lezers tijdelijk tot zwijgen gebracht wordt. Verder blijft de dichter opzettelijk vaag in zijn aanduidingen. Hij zegt niet met even zoovele woorden, dat Mercurius zich werkelijk verwijdert. Vervolgens, als hij de scene tusschen Mercurius en Aglauros weer opneemt, verplaatst hij ons terstond in medias res, en voor wij ons goed en wel georiënteerd hebben, ondergaat de weerbarstige haar straf reeds. Vaagheid en snelheid bemantelen de moeilijkheden, ontstaan door een contaminatie van motieven, die te dankbaar waren, dan dat de dichter ze zich wilde ontzeggen.

\section{EUROPA (II 833-875)}

Deze fabula nota (Fast. 5.604) was in de alexandrijnsche poezie en schilderkunst zeer geliefd; voor de overeenkomsten tusschen Ovidius' versie en die van andere auteurs (in de schildering van den stier, in het motief van het conflict tusschen majesteit en liefde, in de schildering van Europa op den rug van den stier) zie Ehwald ad 833-875. Van Ovidius' voorgangers bezitten wij Moschus' Europeia. Voor ons zijn van belang de opdracht van Juppiter aan Mercurius en het proces der schaking. 
Mercurius krijgt van Juppiter de opdracht de koninklijke kudde naar het strand te drijven, hetgeen hij onverwijld doet. Nauwelijks op den Olympus teruggekeerd na den diefstal van Apollo's runderen en het avontuur met Battus, gevolgd door de galante affaire met Herse, moet hij een galante affaire van Juppiter op gang brengen. Men kan zich niet aan den indruk onttrekken, dat Mercurius' tijd zeer in beslag genomen wordt door amoureuze beslommeringen van hemzelf en van zijn superieur. Ook Lucianus kreeg dezen indruk van Hermes' activiteit in verschillende godenliefdes en gaf er vorm aan in een dialoog tusschen Hermes en zijn moeder: den ganschen dag moet hij op en neer snellen; nauwelijks van een verkenning van Europa teruggekeerd, wordt hij, zonder nog van de vermoeienissen bekomen te zijn, opnieuw uitgezonden, ditmaal naar Argos, naar Danaë, om vandaar, terloops, in Boeotië een blik te werpen op Antiope; een hondenleven (Dial. deor. 24). Heeft ook Ovidius hier zulk een indruk willen wekken? Het is moeilijk te zeggen. Er is een minder malicieuze verklaring te geven : Mercurius dient als verbindingsschakel tusschen de vooorafgaande verhalen en dat van Europa, dat de inleiding vormt op den Thebaanschen cyclus in de twee volgende boeken. $\mathrm{Zijn}_{\mathrm{ijn}}$ optreden hier behoeft echter niet uitsluitend 'een trait d'union te zijn; de inkleeding is in elk geval niet geheel onschuldig : het gedrag van Juppiter is nogal conspiratorisch : hij neemt hem terzijde, en geeft hem, zonder nadere opgave van redenen, een nogal vreemde opdracht, en wel een spoedopdracht. De causa amoris, die Juppiter verzwijgt, verklaart wel den haast, dien hij heeft (tevens zijn wij in medias res verplaatst, en bespaart een korte opmerking ons lange, remmende explanaties).

Het verhaal der schaking vangt met een algemeene beschouwing en een contrast aan :

non bene conveniunt nec in una sede morantur 846

maiestas et amor: sceptri gravitate relicta

ille pater rectorque deum, cui dextra trisulcis

ignibus armata est, qui nutu concutit orbem, induitur faciem tauri mixtusque iuvencis

mugit et in teneris formosus obambulat herbis.

Heinze (104 v.) ziet in deze verzen een betuiging van leedwezen, een poging van Ovidius om het "onvermijdelijk bezwaar" tegen 's goden dierengestalte te anticipeeren. In werkelijkheid vormen zij een meesterstuk van artistieke ironie ; het thema is conventioneel, doch de uitwerking en inkleeding boven allen lof verheven. Eerst een algemeene sententie, dan de concreete toepassing, en wel twee plastische beelden, dat van den majesteitelijken Donderaar en dat van een stier, loeiend en stappend tusschen de vaarzen in het gras, beide beelden samengevat in één periode, die, na de epische zwelling van den voorzin, tot in den val van den nazin het contrast illustreert. En het verhaal ondervindt geen vertraging : wij zijn ongemerkt in medias res verplaatst. Leerzaam is een vergelijking met een soortgelijke opmerking van Nonnus (het betreft Zeus, verliefd op Persephone): 


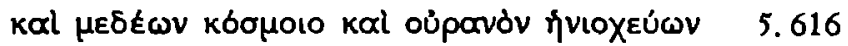

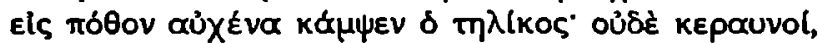

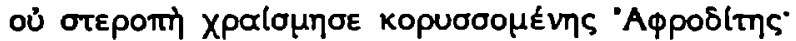

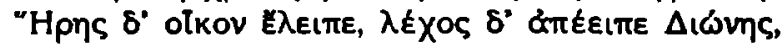

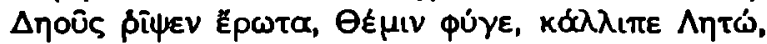

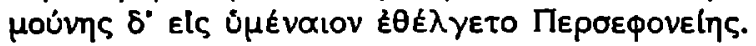

Voor Nonnus was er nauwelijks reden voor een bespiegeling over majesteit en liefde; het betreft de liefde tot een godin, niet tot een sterfelijke. $Z_{i j n}$ opmerking mist ook de plastische, vizueele kracht van de Ovidiaansche; "den nek buigen" is spreekwoordelijk en spreekt niet bijzonder tot de fantasie; een opsomming van Zeus' vroegere goddelijke geliefden moet aan den commentaar substantie geven, en hieraan moet de formeele variatie een schijn van sprankeling verleenen. De passage van Nonnus is een mechanisch product; de verzen van Ovidius vatten de quintessens der situatie met groote trefzekerheid samen.

Juppiter-stier weet Europa op zijn rug te lokken en te ontvoeren. Bij Moschus (89 vv.) gaat alles nogal bovennatuurlijk in zijn werk: een afzonderlijk. opereerende schoone stier komt recht op de bloemen plukkende meisjes af, die in het geheel niet schrikken, doch zich terstond tot hem voelen aangetrokken; een goddelijke geur gaat er van den viervoeter uit; hij komt vlak voor Europa staan, en likt haar; zij kust hem; hij laat een verrukkelijk geloei hooren, als fluitspel, hurkt neer, wijst op zijn rug, springt, zoodra zij erop zit, overeind en rent zeewaarts. Als dit geen heel bijzondere stier is, wat is het dan wel ? Ovidius daarentegen elimineert alle bovennatuurlijke trekken; geen buitenstaander kan in de manoeuvres van den stier goddelijke macht vermoeden, zoo geraffineerd gaat alles in zijn werk : alles is erop berekend aannemelijk te maken, dat een schrikkig meisje zich durft te wagen op den rug van niet minder dan een stier. Het eenige goddelijke aan den stier is zijn uitzonderlijke schoonheid (door de poezie gegeven). Deze stier komt niet pardoes op de meisjes af, doch is het sieraad der koninklijke kudde. Zijn schoonheid trekt de aandacht, zijn vreedzaamheid wekt verwondering. Doch ook zoo wijkt de angst der meisjes slechts geleidelijk, plaats makend voor vertrouwdheid en vriendelijkheid. Europa geeft hem dan zelfs bloemen, hij likt erkentelijk haar hand, stoeit nu eens, gaat dan weer liggen in het gras, laat zich op de borst kloppen en zich bekransen. De grondtoon is : paulatimque metu dempto (866). Eindelijk ausa est (868) op den rug van den stier te gaan zitten. En dan geen oogenblikkelijke galop, maar voetje voor voetje (sensim 870) gaat het zeewaarts. Heinze (p. 58) merkt terecht op, dat bij Ovidius alles op het winnen van Europa's vertrouwen berekend is ; doch zijn verklaring hiervan, dat $\mathrm{nl}$. Ovidius, door het bedwingende van den stier te laten uitkomen, het aanstootelijke van den god in dierengestalte zooveel mogelijk heeft willen wegwerken, gaat scheef. Bedwingend is de stier van Moschus ; bij Ovidius gaat uiterlijk alles uiterst natuurlijk ; de lezer echter weet, dat hier een verleider zijn snood spel speelt (fert praedam 873): het curieuze van een stier als verleider amuseert onzen dichter : het is een ars casu similis (Ars 3. 155); hij heeft de maxime si latet ars, prodest (Ars 2.313) aan de uitzonderlijke 
omstandigheden aangepast. Steekt in de schildering van het sluw gemanoevreer van den god-stier reeds een ironisch moment, de dichter kan niet nalaten den draak te steken met Juppiter's heete lust :

gaudet amans et, dum veniat sperata voluptas, 862 oscula dat manibus; vix iam, vix cetera differt.

Oscula en cetera herinneren aan het openhartige distichon der Ars: oscula qui sumpsit, qui non et cetera sumpsit, Haec quoque quae sumpsit perdere dignus erat (1. 669 v.). Hoe Juppiter op oscula sneller reageert dan zijn bliksem, heeft "Callisto" ons geleerd. In het emphatische vix iam vix klinkt het leedvermaak van den dichter door om het gedwongen uitstel.

In "Callisto" is opgemerkt, hoe gunstig Ovidius' spel met Juppiter's begeerlijkheid afsteekt van dat der comedie-dichters. Hetzelfde kunnen wij ook hier constateeren. Uit de „Europa” van Plato (midden comedie) is ons een veelzeggend fragment bewaard gebleven (Kock I 611 fr. 43): Zeus wil de slapende Europa te lijf gaan, doch iemand (Hermes?) weet hem hiervan af te houden, betoogend, dat de werken der liefde, aan de ontwaakte bedreven, veel meer wellust schenken. Het is een vulgaire grofheid om risu diducere rictum, terwijl bij Ovidius' suggesties den lezer een glimlach om den mond speelt.

Een bekend alexandrijnsch verhaal, niet zonder alexandrijnsche motieven; de scene tusschen Juppiter en Mercurius, zooals ze bij Ovidius voorkomt, is waarschijnlijk zijn eigendom; het conventioneele motief van het conflict tusschen majesteit en liefde heeft hij op zeer gelukkige wijze benut en ingekleed; de schildering van de schaking is wel zijn eigendom; de ironie viert hoogtij.

\section{ACTTAEON (III 138-252)}

Het verhaal van Actaeon mocht zich in de belangstelling der alexandrijnsche dichters verheugen. Ehwald (ad 131) meent in Ovidius' versie naast eigen elementen invloed van Callimachus en nog een ander alexandrijnsch voorbeeld te bespeuren. Ook Nonnus' versie kan voor een bestudeering van Ovidius' verhaal goede diensten bewijzen. Verder is het waarschijnlijk, dat de schilderkunst invloed op Ovidius' voorstelling van het verhaal gehad heeft. Voor ons zijn hier van belang : het bad van Diana, en haar wraak.

Van de grot in de Gargaphië-vallei, waarin Diana haar bad neemt, zegt de dichter, dat zij was

arte laboratum nulla: simulaverat artem 158

ingenio natura suo; nam pumice vivo

et levibus tofis nativum duxerat arcum.

Dus niet ars casu similis, doch casus arti similis. De dichter prent ons met al zijn betuigingen van de natuurlijkheid der grot slechts vaster in, dat wij ons een kunstgrot moeten voorstellen, zooals zij te Rome geliefd waren en ook gaarne geschilderd werden ( $\mathrm{Grima} 1$ p. 152). Over den aard der verschillende soorten puimsteen sprekend, merkt Plinius maior op, dat men ook wel bij de kunst- 
grotten (musaea)van puimsteen spreekt, ofschoon hier niet van echte puimsteen (pumex vivus) sprake kan zijn (Nat. Hist. 36. 42. 154). Naar zulke kunstgrotten verwijst Ovidius niet enkel in "Actaeon"; de grot in het verhaal van Thetis en Peleus wordt meer een kunst- dan een natuurproduct genoemd : et specus in medio, natura factus an arte Ambiguum, magis arte tamen (11.235 v.). Aan een kunstgrot denkt Ovidius ook wel in de Amores : fons sonat in medio speluncaque pumice pendens (3.1.3 ; zie Brandt t.p. in den aanhang); tenslotte gelijkt de grot in het verhaal van Hercules, Omphale en Faunus op die in „Actaeon": antra subit tofis laqueata et pumice vivo (Fast. 2.315). In het heilige woud dus van de Gargaphië-vallei, in het hartje van Griekenland in mythische tijden, worden wij aan Romeinsche (Romeinsch-alexandrijnsche) parkarchitectuur herinnerd.

In deze grot nu placht Diana te baden, in een grot, terwijl dit elders, voorzoover mij bekend, steeds in de open lucht geschiedt : noch bij Nonnus, in zijn verhaal van Actaeon (5.287 vv.), noch bij Callimachus, in het Bad van Pallas (v. 71 wordt enkel een bron genoemd), is van een grot sprake; en ook bij Ovidius zelf, in "Callisto" (2.454/60), heeft Diana's bad in de open lucht plaats. De grot is daarom wellicht een innovatie van Ovidius zelf, wellicht te wijten aan invloed der schilderkunst (zie verderop), waarbij misschien nog komt, dat het idee van casus arti similis Ovidius wel toelachte.

Uitvoerig wordt de bediening van Diana beschreven. Reeds Callimachus in zijn Artemishymne schildert uitvoerig, hoe voorkomend Artemis bediend wordt : als zij van de jacht op den Olympus terugkeert, komen haar in den voorhof Hermes en Apollo tegemoet, de eerste om haar van haar wapenen te ontdoen (Hermes is de bediende op den Olympus), laatstgenoemde om zich over den buit te ontfermen (142 vv.); de nymphen, die zij voor haar bediening heeft (15/7), verzorgen verder haar reeën (162 vv.). Bij Nonnus, in het verhaal van Aura, komt een badscene voor, die eenige overeenkomst vertoont met die van Ovidius in "Actaeon". De nymphen helpen haar meesteres :

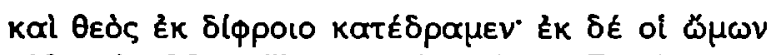

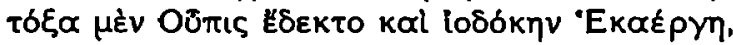

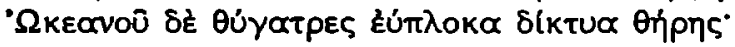

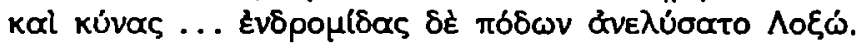

De namen der nymphen zijn ontleend aan Callimachus' Deloshymne 292 Oõ $\pi(\varsigma$

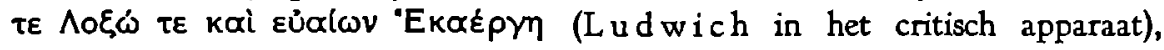
welke namen Nonnus ook benutte in zijn verhaal van Actaeon (489/91), zij het ook niet voor de bediening. Welke is de verhouding tusschen Nonnus en Ovidius? Inspireeren zich beiden op een alexandrijnsch voorbeeld van bediening der badende Diana? B ra u ne (p. 33/8), ofschoon hij bewijzen wil, dat Nonnus Ovidius' „Actaeon" gekend en benut heeft, rept over deze scene met geen woord. Indien echter Ovidius zich op een alexandrijnsch voorbeeld geinspireerd heeft, dan heeft hij zich in de uitwerking toch stellig ook door het Rome van zijn eigen tijd laten leiden :

Aan een der nymphen overhandigt de godin haar jachtgerei, aan een andere haar kleed, een derde en een vierde ontdoen haar van haar schoeisel, een vijfde 
maakt heur haar op. Volgens Couat (p. 290) zijn wij getuige „comme au déshabillé d'une dame romaine". R ib beck (p. 301), met instemming geciteerd door $\mathrm{Eh}$ wald (ad 165), merkt op: „Man denkt an die Bedienung einer vornehmen Römerin". L a f a y e (Met. p. 139), stelling nemend tegen Cou at, die vervolgde met "de celles qui ne craignent pas d'être vues", merkt op, dat Diana ondanks alles godin blijft, de meesteres, en hij heeft ten deele gelijk, indien hij namelijk bedoelt, dat er van coquetterie geen sprake is, bij Diana welteverstaan (de dichter coquetteert wel degelijk). Dat Ovidius bij dit gracieuze tafereel Rome voor oogen heeft, blijkt uit de wijze, waarop hij over de kapster spreekt : doctior wordt deze genoemd (168), hetgeen herinnert aan docta neque ancillas inter habenda, in de Amores (1.11.2) van Corinna's ornatrix gezegd. Als zoodanig geeft Ovidius van de ornatrix zoowel naam als patronymicum (Ismenis Crocale 169), terwijl de garderobe-nymphen naamloos blijven. Dit is bekoorlijke scherts, en $\mathrm{Cou}$ a t voelde intuitief, aan welk milieu Ovidius in deze verzen dacht, aan het milieu van Corinna en de demi-monde.

Vervolgens worden nog vijf baadsters genoemd, die zeer toepasselijke namen hebben: Nephele, Hyale, Rhanis, Psecas, Phiale, d.i. Wolk, Kristal, Druppel, Stofregen, Schaal (E h wald ad 169). Men mag veilig aannemen, dat voor deze namen een Grieksche bron, welke dan ook, aansprakelijk is.

Een deel van de bekoorlijke ironie van dit tafereel ligt in de omstandigheid, dat wij weten, dat deze idylle niet ongestoord zal blijven. Een hoogst penibele situatie ontstaat, als Actaeon komt opdagen, plotseling aan den ingang der grot. $\mathrm{O}_{\mathrm{p}}$ het zien van den manspersoon stellen de nymphen zich, sicut erant nudae (178), onder luid misbaar, dekkend rond haar naakte meesteres. Nochtans steekt de godin tot de schouders boven haar gezellinnen uit; blozend wendt zij zich zijwaarts af. Men heeft bij dit tafereel aan invloed der beeldende kunsten gedacht; Couat (p. 290) spreekt van een sculpturale houding: Ribbeck (p. 309) heeft den indruk, dat de groep aan een schilderstuk ontleend is; niet onwaarschijnlijk: de naakte groep levert een prachtigen aanblik tegen den donkeren achtergrond der grot. Doch mocht Ovidius werken der beeldende kunsten voor oogen hebben gehad, dan is daarnaast toch ook waar, dat hij de motieven fijn litterair interpreteert. Dacht de schilder aan de bekende Artemisvergelijking van Homerus (6.107), toen hij Diana uitbeelde, uitrijzend boven de nymphen, Ovidius citeert een hemistiche uit Vergilius' bewerking (gradiensque deas supereminet omnis, 1.501), als hij ondeugend constateert: tamen altior illis Ipsa dea est colloque tenus supereminet omnis (181 v.). Wat bij Vergilius haar glorie verhoogt, maakt bij Ovidius voor haar de situatie zoo penibel. Zonder eenigen haast schildert de dichter den diepen blos op haar wangen : 183/5; misschien mogen wij in de spondaeën en den hiaat van purpureae Aurorae een illustratie van 's dichters leedvermaak zien. Hij wijst ook op het overbodige van haar reflex-beweging, dat zij, ofschoon door haar nymphen gedekt, toch schuin ging staan : quamquam - tamen (186 v.). Nonnus schildert, hoe Artemis, half zichtbaar in het water, naar haar kleed grijpt on haar borsten aan de blikken van den gluurder te onttrekken en zelfs even geheel onder water duikt (311/5): alleszins vermakelijk. Heb ik het echter wel, dan steekt in Ovidius' beschrijving 
der situatie ook een zeker malicieus element, en geniet hij met leedvermaak van Diana's grondelooze en machtelooze verlegenheid: zij staat aan den grond als vastgenageld. $\mathrm{Zijn}_{\mathrm{ijn}}$ leedvermaak geldt daarbij niet de godin in haar, alswel de preutsche maagd. (Men herinnere zich de hopelooze onnoozelheid van Diana in "Callisto".) In deze momenten van machtelooze „schande" ligt de reden van haar matelooze wraak.

Actaeon is het slachtoffer van een ongelukkigen samenloop van omstandig. heden. De dichter neemt hem bij den aanvang van het verhaal reeds in bescherming :

at bene si quaeras, Fortunae crimen in illo, 141

non scelus invenies; quod enim scelus error habebat?

Op Actaeon's onschuld wordt alle nadruk gelegd. Hij dwaalt door een hem onbekend bosch ; hij dwaalt rond met onbepaalde bestemming, slechts op zoek naar water. Hij kon niet weten, dat Diana in die bepaalde grot placht te baden; en hij had ook niet de bedoeling haar te verrassen; het was eenvoudigweg zijn noodlot: sic illum fata ferebant (176). Hiertegenover staat, dat Diana zich wreekt uit gedeerde preutschheid, misschien ook omdat zij hem van boozen opzet verdenkt, getuige het grimmige nunc tibi me posito visam velamine narres, $S_{i}$ poteris narrare, licet! (192 v.), en in de laatste verzen van het verhaal insisteert de dichter op haar wreedaardigheid : nec nisi finita per plurim a vulnera vita Ira pharetratae fertur satiat a Dianae (251 v.).

Hoe anders is de Pallas uit Callimachus' hymne. Tiresias ook zag oủk żét $\lambda \omega v$ (78), wat te zien niet geoorloofd was; $o$ k hij is een speelbal van hoogere machten

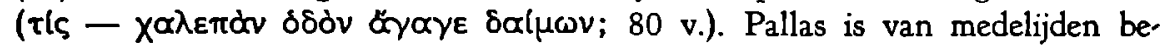
vangen met den ongelukkige; niet zij, maar de hoogere beschikkingen slaan hem met blindheid (98 vv.). Als zijn moeder, haar vriendin, de godin met verwijten overstelpt, herinnert deze aan het lot van Actaeon, die een vreeselijk lot onderging, ofschoon ook hij geen booze bedoelingen had (koủk $\varepsilon \theta \varepsilon \lambda \omega \nu$ 113). Zi el inski (p. 269) ziet in deze passage een invectiva dissimulata, en het heeft er ook allen schijn van, dat Callimachus de sage grondig wijzigde : want terwijl hij met geen woord van een gebaar der godin rept, maakte Pallas in de versie van Pherecydes hem blind door persoonlijk ingrijpen, ingrijpen in den letterlijken

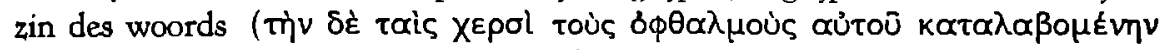

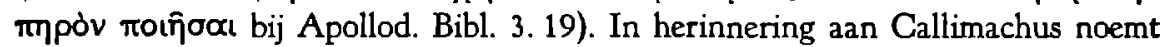
Nonnus de godin dan ook oiktip $\mu \omega v$ (338), in tegenstelling met Artemis ßopúфpwv (327). Dit epitheton kan ook gelden van de Ovidiaansche Diana : dat zij Actaeon met water besprenkelt (omdat zij haar pijlen niet bij de hand heeft), is het uitwendig teeken van haar persoonlijk ingrijpen.

Bij Nonnus is de wraak van Artemis, die wil, dat Actaeon bij volle bewustzijn stukje voor stukje door zijn eigen honden opgevreten wordt, alleszins gerecht-

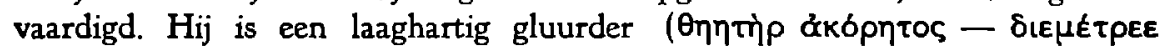
305 v.), en droomt verwaten van een huwelijk met de godin (433 vv.). Was dit de voorstelling van een of anderen alexandrijnschen dichter of van een compendium, dat ook Ovidius kende? Kienzle (p. 29 n. 15) en Ehwald (ad 176) 
zien in sic illum fata ferebant polemiek van Ovidius tegen andere opvattingen, welke hij in zijn compendium vermeld zag. Hoe dit ook zij, Ovidius' voorstelling van zaken komt overeen met die van Callimachus in zake de schuldvraag. $\mathrm{Hij}$ volgt dezen echter niet in de schildering van de wraak. Het is mogelijk, dat hij in het eerste Callimachus' wijziging volgde, in het tweede de oude, misschien door een alexandrijnschen dichter gehandhaafde voorstelling; het resultaat is iets nieuws: Actaeon verdient deze wreede straf niet, het gedrag van Diana kan verontschuldigd worden met een beroep op een misverstand, dat zij namelijk van zijn boozen opzet overtuigd is. Ook onder de goden zelf heerscht oneenigheid omtrent de billijkheid van de straf : pars invenit utraque causas (255). Misschien heeft Ovidius deze "tragedy of errors" gewild ; leest men het verhaal echter in zijn geheel, met zijn beminnelijke ironie en esprit, dan is men geneigd, deze bloeddorstige wraak aan gelaedeerde preutschheid te wijten en van diepzinnige interpretaties af te zien.

Pohlenz (p.11/2) heeft de veronderstelling geopperd, dat in dit verhaal Ovidius zijn eigen lot in dat van Actaeon heeft verwerkt. Dit zou dan een wijziging en bewerking in de Metamorphosen veronderstellen, na zijn verbanning ondernomen. De suggestie is verleidelijk; de nadruk, die op Actaeon's onschuld gelegd wordt, de "tragedy of errors" zou ermede verklaard kunnen worden, alsook de emphase, waarmede de dichter crimen en error onderscheidt, een onderscheiding uit de ballingsgedichten maar al te bekend. Tenslotte kan men erop wijzen, dat Ovidius zich in zijn ballingsgedichten met Actaeon vergelijkt (Trist. 2.103 vv.; Ehwald ad 141). Nochtans kunnen al deze merkwaardigheden verklaard worden ook zonder dat men een bewerking dezer episode na de verbanning aanneemt. Neemt men als drijfveer van Diana's wraak gelaedeerde preutschheid aan, dan is daarmede haar bloeddorstige wraak verklaard. Diana staat overigens ook in andere verhalen om haar felle wraak bekend; Acontius zegt in zijn brief van haar: nihil est violentius illa, Cum sua, quod nolim, numina laesa videt (Her. 19.99 v.), verwijzend naar den Calydonischen ever, Actaeon en Niobe. Uit de Metamorphosen kan men nog Chione aanhalen. Doordat Actaeon als het onschuldig slachtoffer van het lot wordt voorgesteld, komt de heftigheid van Diana's wraak nog meer uit. Voor een dergelijke voorstelling van zaken wees Callimachus reeds den weg. Ook bij Nonnus overigens ontbreekt

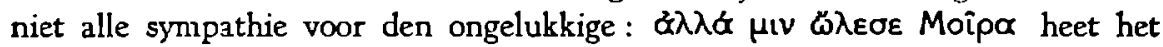

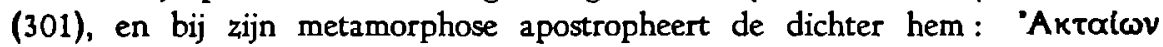

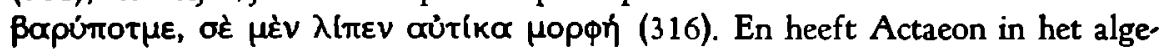
meen een goede pers, Diana daarentegen niet, dan behoeft het niet te bevreemden, dat Ovidius hierop, ook zonder zichzelven met hem te identificeeren, met zijn gebruikelijke brio en distincties reflecteert. Wat betreft de meeningsverschillen onder de goden : aan welke kant Ovidius staat, is duidelijk; het idee zelf al van meeningsverschillen is veelzeggend; dit blijft waar, ook al hebben ze tot doel den overgang naar het volgend verhaal in te leiden. 


\section{SEMELE (III 253-315)}

Ovidius begint het welbekende verhaal van Semele's ondergang bij het opwindende moment, waar Juno besluit haar mededingster in het verderf te storten : semper ad eventum festinat et in medias res Non secus ac notas auditorem rapit. Voor iurgia is Juppiter niet gevoelig; men lette op het woord totiens, dat ook reeds in "Io" voorkomt (1.606). Het oude vuur van haar ontboezemingen is ook hier niet gedoofd. Kostelijk is, hoe zij in groote opwinding haar eigen onmacht verraadt :

concipit! id deerat! manifestaque crimina pleno 268

fert utero et mater, quod vix mihi contigit, uno

de Iove vult fieri : tanta est fiducia formae!

Noteeren wij, met het oog op wat nog volgt, dat volgens Juno Semele hoogst aanmatigend is, niet tevreden met een kortstondig furtum, hoogmoedig (enkel bij Juppiter, den hoogsten god, wil zij moeder worden), omdat zij de aantrekkingskracht van haar mooie lichaam kent. Ovidius persifleert verder Vergilius : bij dezen heet het: ast ego, quae divum incedo regina Iovisque Et soror et coniunx $(1.46 \mathrm{v}$.); twee woorden bij Ovidius blazen deze indrukwekkende tirade op : si sum regina Iovisque Et soror et coniunx, certe soror (265 v.; vgl. maxima Iuno: Verg. 4. 371, 10.685; Ovid. 263).

Eenmaal haar besluit genomen, verheft zij zich van haar zetel om de daad bij het woord te voegen. De vermelding van haar zetel, den zetel harer geschonden majesteit, brengt ons de hoogheid der hemelkoningin in herinnering, de Juno der epiek. Fulva recondita nube (273) zoekt zij het vertrek van Semele op. De beschermende omhulling eener wolk is uit de epiek welbekend; fulva nube (het is de eenige maal, dat Ovidius fulvus voegt bij nubes) is ontleend aan de Aeneis, waar Juno den beslissenden strijd tusschen Aeneas en Turnus gadeslaat fulva de nube (12.792). De reminiscenties aan Vergilius en de hooge epiek (de genoemde zijn niet de eenige in dit verhaal, zooals wij zullen zien) dienen om het contrast te verscherpen tusschen haar eigenlijke, goddelijk hooge verhevenheid der epiek en haar feitelijke, menschelijk lage gedrag in het vervolg van het verhaal. Haar arglistigheid wordt nog op allerlei wijzen onderstreept. Haar vermomming als oude vrouw wordt uitvoerig beschreven (275/7, wel niet zonder herinneringen aan Vergilius $7.416 \mathrm{v}$.) ; uitdrukkelijk heet het : vocem quoque fecit anilem; zij is in niets meer godin, doch een krassende oude bes. $\mathrm{Zij}_{\mathrm{ij}}$ neemt de gedaante aan van Semele's voedster, die volgens Ovidius (Nonnus noemt geen naam in de correspondeerende passage) Beroë heet, een naam, misschien niet zonder bedoeling aan die passage van Aeneis V ontleend, waar Iris, op Juno's bevel, in de gedaante van de oude Beroë de Trojaansche vrouwen opruit tot een noodlottigen stap : nomen est omen. De levendige, levensechte, satirische wijze, waarop de dichter van haar sluwe tactiek en inblazingen vertelt, herinnert sterk aan de mimiamben van Herondas of aan de comedie, en is van alle epische allure gespeend; geen rede van Juno zooals bij Nonnus, doch sermo cotidianus, in verzen gegoten, die in natuurlijkheid voor den Horatiaanschen keuveltrant niet onderdoen : 
ergo ubi captato sermone diuque loquendo 279

ad nomen venere Iovis, suspirat et 'opto,

Iuppiter ut sit' ait 'metuo tamen omnia: multi

nomine divorum thalamos iniere pudicos.

Juno moet het bij Ovidius deerlijk ontgelden. Dit blijkt nog duidelijker, als wij het karakter van Semele vergelijken bij Nonnus en bij Ovidius. Bij Nonnus is zij bovenal grenzeloos hoogmoedig. $\mathrm{Zij}$ is niet tevreden met wat Zeus' overige aardsche liefjes bezitten, doch wil geheel gelijk zijn aan Hera (8.301 v.). De drijfveer van haar verzoek, dat Juppiter haar in volle waardigheid als bliksem. slingeraar bezoekt, is : hiermede haar zusters Agaue en Autonome jaloersch te maken. Als voorwendsel geeft ze op, dat het verschijnen van Zeus' bliksem het zwijgen zal opleggen aan de sceptische praatjes over haar mysterieuzen minnaar. Wanneer zij den bliksem ziet, is zij buiten zichzelf van vreugde, en denkt aan haar zusters, die dit met leede oogen zullen zien (395). Later nog, als hemelsche godin, wanneer Ino in de godin Leucothea veranderd is, kan zij niet nalaten om snoevend te constateeren, dat haar eigen rang hooger is (9.206/48). Wij kunnen daarom met haar lot geen sympathie voelen : de benepen arrogante verdient de wraak van Hera volkomen.

Bij Ovidius staan de zaken anders : wel hooren wij van haar hoogmoed, doch enkel bij monde van Juno, en de vehemente Juno is een onbetrouwbare getuige (men herleze bijv. haar expectoraties in "Callisto"). Juno weet overigens wel beter, want zij zaait twijfel in Semele's hart omtrent de goddelijkheid van den minnaar. Dit doet de Hera van Nonnus niet, integendeel, zij vleit de ijdele,

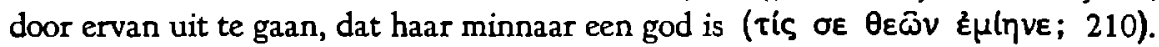
Juppiter's verschijnen in donder en majesteit is daarom voor de Ovidiaansche Semele in de eerste plaats een bewijs van de waarachtigheid zijner woorden, niet iets om op te glorieeren. Semele is het slachtoffer harer susceptibiliteit. Het is moeilijk, iets stelligs te zeggen over de verhouding tusschen Ovidius en Nonnus, Nonnus' directe afhankelijkheid of beider afhankelijkheid van een gemeenschappelijke bron; het heeft er echter den schijn van, dat Ovidius in de schildering van Semele's karakter modificeert, Nonnus exaggereert, dat Ovidius, om Juno's arglist te vergrooten, Semele zoo onschuldig mogelijk voorstelt; van het motief van Semele's hoogmoed maakt hij enkel nog gebruik om Juno eens ouderwets te laten doordraven. (Zie ook "Callisto".)

Juno's gedrag in "Semele" is dus het tegendeel van verheffend ; en de dichter heeft dit gewild, weshalve hij het contrast met haar eigenlijke goddelijke verhevenheid levendig houdt, voor persiflage niet terugdeinst, en waarschijnlijk de fabel niet onbelangrijk modificeert. Het is goed hierbij op te merken, dat hij haar niet zoozeer aan de verachting prijsgeeft, als wel een loopje met haar neemt en zich over haar vroolijk maakt.

Vroolijk maakt hij zich ook over den minnaar, over Juppiter. Daar zijn in de eerste plaats de biotische trekjes in het relaas van Semele's verzoek. Echt vrouwelijk vraagt deze haar minnaar eerst een sine nomine munus (288) ; deze, tot over zijn ooren verliefd, staat terstond klaar met een ,elige' (289). Op puntige wijze 
(men lette ook op het versrythme) geeft de dichter commentaar op de ironie der situatie: laeta malo nimiumque potens perituraque amantis Obsequio (292 v.). Tenslotte, als zij haar noodlottig verzoek doet, wil de god haar nog de hand voor den mond houden $(295 \mathrm{v}$.), doch te laat. In de tweede plaats schertst Ovidius met Juppiter's bliksem : hij weet te vertellen, dat Juppiter met zijn lichter geschut komt aandragen : tela secunda vocant superi (307), een tintelende vondst, even ondeugend ten opzichte van den Donderaar als ten opzichte van de oude aëden, die met groote naiveteit miraculeuze kennis droegen van godengeheimen, van een plant bijv., die door de goden moly genoemd wordt (Hom. 10.305; cf. Ovid. 14. 292), of van het godenbloed ix $x \rho$ (Hom. V $340 \mathrm{vv}$.), of van de rivier, die de menschen Scamander noemen, maar de goden Xanthus (Hom. XX 74; cf. Met. 11.640). Ook Juppiter is dus het slachtoffer van Ovidius' luim.

\section{LIS IOCOSA (III 316-338)}

Uit Hesiodus (Melamp. $162 \mathrm{Rz}$.) is het volgende verhaal bekend : tusschen Zeus en Hera rees een meeningsverschil omtrent de vraag, of de wellust der mannen dan wel die der vrouwen grooter was. $\mathrm{Z}_{\mathrm{ij}}$ raadpleegden Tiresias, die tot oordeelen bevoegd was, daar hij gedurende eenige jaren vrouw was geweest. Toen deze Zeus in het gelijk stelde, dat de wellust der vrouwen grooter was, nam Hera wraak door den scheidsrechter met blindheid te slaan; waarop deze van Zeus als recompensatie de zienersgave ontving. Aldus vertelt ook Ovidius; en toch is het verhaal door de inkleeding ervan geheel anders geworden. In geraffineerden keuveltrant, losjes, vertelt hij :

forte Iovem memorant diffusum nectare curas 318 seposuisse graves vacuaque agitasse remissos cum Iunone iocos.

Zelfs bij een Ovidius is deze voorstelling van zaken gedurfd. Het is wel heel erg menschelijk. Juppiter inter plena meri redimitus pocula sertis (9.238); Juppiter boertend met zijn matrone in huiselijken kring; het meest verrast ons nog de lichtzinnigheid zijner matrone. Zooals Ovidius het voorstelt is de kwestie van de wellust van man en vrouw niet zoozeer een geschilpunt en strijd. vraag als wel een kwestie van luim en plagerij; het zijn ioci, het is een lis iocosa (332), en dit maakt het onderwerp van de scherts zoo frivool. Weliswaar komt dit thema reeds bij Hesiodus voor, doch Ovidius heeft er de inkleeding aan gegeven, die daarbij past en gebruikelijk was : Wein, Weib und Gesang. Daarom worden wij sterk herinnerd aan de alexandrijnsche erotiek en aan de erotische elegie ( $\mathrm{E} h$ wald ad 320 ). Het is een vermakelijke gedachte.

Doch het feit, dat wij hier met een lis iocosa te doen hebben, heeft consequenties voor de waardeering van Juno's reactie. $Z_{i j}$ verstaat, de matrone, geen humor, in dit punt in het geheel niet; zij trekt het op haar fatsoen, en verliest alle proporties uit het oog. De dichter constateert dan ook onomwonden, dat zij hierop reageert gravius iusto nec pro materia (333 v.). Onschuldige scherts leidt door haar benepenheid tot echtelijke onmin. Juno vertegenwoordigt de matrone 
in haar onsympathieken vorm; van haar kon geschreven zijn : dos est uxoria lites (Ars 2.155).

$$
\text { ECHO (III 362-369) }
$$

Veelzeggend zijn uit dit verhaal de verzen, waarin de reden gegeven wordt van het feit, dat Echo enkel de laatste woorden van anderen kan herhalen. Wij proeven er 's dichters leedvermaak uit :

fecerat hoc Iuno, quia, cum deprendere posset

362 sub love saepe suo nymphas in monte iacentis, illa deam longo prudens sermone tenebat. dum fugerent nymphae.

De verzen teekenen Juppiter als de nymphenjager, Juno als de achtervolgster, zooals wij haar in "Io" hebben leeren kennen. Men lette op saepe : zoo is Juppiter nu eenmaal ; en op suo : Juno is naijverig op haar rechten. Juppiter wordt niet gespaard : sub Iove iacentis laat aan duidelijkheid niets te wenschen over. Juppiter, Juno en de nymphen : iets prettigers is er voor Ovidius niet te denken.

\section{MARS ET VENUS (IV 171-189)}

Dit verhaal, uit Homerus bekend, geeft Ovidius als inleiding op het eigenlijke thema, Solis amores (170). Als men denkt aan Sol en liefde, gaan de gedachten onwillekeurig uit naar de rol, door Sol gespeeld, in de liefde van Mars en Venus. Daarbij komt, dat Sol's avontuur met Leucothoë een ontijdig einde vindt door de klikkerij van Clytie, zooals dat van Mars en Venus door Sol's klikkerij. Sol's eigen liefde wordt daarom voorgesteld als een wraakoefening van de beleedigde Venus. Ons verhaal is dus een passende inleiding op "Leucothoe"; het verband is wel door Ovidius zelf gelegd ( $\mathrm{E} h \mathrm{w}$ ald ad 4. 36). Ovidius laat dit verhaal, dat hij in de Ars (2.561 vv.) reeds op pikante wijze verteld had, nog eens kort, doch niet onschuldig, de revue passeeren. Allerwegen gluurt het gezicht van den mondainen dichter om den hoek, en worden wij aan Rome herinnerd. Talrijk zijn voor het gering aantal verzen de termen van echtbreuk: het is adulterium (171) ; Vulcanus is de maritus (173), Venus en Mars worden aangeduid met coniunx et adulter (182). Vulcanus is de vir (183), de spotschijf der elegie, en ook hier maakt de dichter zich over hem vroolijk: men lette op het oolijk zeugma in de schildering van zijn reactie : et mens et quod opus fabrilis dextra tenebat, Excidit (175 v.). Speciaal de ontknooping is vol suggesties:

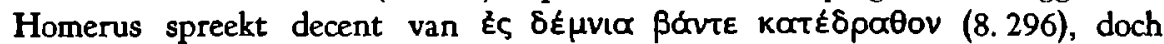
Ovidius' in mediis amplexibus (184) laat aan duidelijkheid niets te wenschen over. Vermakelijk is de referaatstijl in: Lemnius extemplo valvas patefecit eburnas Inmisitque deos $(185$ v.). Men gaat denken aan het openen der theaterpoorten voor de beluste drommen : praebent spectacula capti (Ars 2. 581). Het bekende gesprek tusschen Apollo en Hermes had niet puntiger kunnen worden saamgevat dan hier : Ovidius spreekt met pikante onbepaaldheid, evenals in de Ars (2. 585; zie $\mathrm{Br}$ andt t.p.), van aliquis; en deze aliquis behoort tot de di non tristes, de 
goden naar zijn hart, want waarom schildert hij in de Fasti Flora met zooveel charme? non est de tetricis (5.351), en, zoo verklaart hij in de Amores, als hij zelf god was, non de tetricis dicerer esse deis (3.3.46); de wensch van dezen god is in een oxymoron vervat : optat Sic fieri turpis (187 v.). De dichter weet te vertellen - en het idee was hem dierbaar, daar hij het reeds tweemaal gebruikt had, in de Amores (notior in caelo fabula nulla fuit, 1.9.40) en in de Ars (fabula narratur toto notissima caelo, 2.561) - : diuque Haec fuit in toto notissima fabula caelo (188 v.) : belust op amoureuze schandaaltjes, zoo mag men 's dichters woorden interpreteeren, ,tout comme chez nous". Het geheel ademt de mondaine sfeer van Rome. Wie aan de Romaniseering mocht twijfelen, vergelijke nog met Homerus' $\chi \propto \lambda$ koßatès $\delta \bar{\omega}$ (8.321) Ovidius' valvae eburnae (185), die herinneren aan de woningluxe van Ovidius' tijd, evenals ebore et testudine cultos - thalamos in het verhaal van Herse (2.737; $\mathrm{E} \mathrm{h}$ w ald t.p.).

Merkwaardig is, hoe sommige critici blind zijn voor de pikanterie in dit relaas. La f a ye (Met. p. $101 \mathrm{v}$.) vindt Ovidius hier alleszins discreet; dat de dichter zich niet zoo naief liet gaan als de oude aëden, wijt hij aan "le bon ton, sinon la morale", die ten tijde van Augustus meer terughoudendheid in het epos zou verlangen. $\mathrm{He}$ in ze (p. 14 v. + n. 1) vindt eveneens, dat Ovidius alles ,zurückhaltend und ehrbar" beschreven heeft; de scherts van Apollo en Hermes is "so dezent wie möglich" weergegeven ; bovendien, zoo betoogt hij, is het verhaal niet doel in zichzelf, doch als inleiding gegeven. Mogen we H e in z e gelooven, dan zou Ovidius aanstoot aan het verhaal genomen hebben, ware het niet, dat de stof door Homerus episch gelegitimeerd was. Het ontbrak er nog maar aan, dat deze inleiding als volstrekt noodzakelijk werd voorgesteld. In denzelfden geest zou men kunnen betoogen, dat het verhaal zoo obscuur was, dat men er niet in enkele verzen naar verwijzen kon, doch er tenminste twintig aan moest besteden. Nochtans, als men ergens op wil wijzen, moet het niet zijn de kortheid van Ovidius' referaat, doch de betrekkelijke lengte ervan.

\section{LEUCOTHOE (IV 190—270)}

De dichter stelt het voor, alsof Sol's liefde een wraakoefening van Venus is; vandaar een hevige verliefdheid en daarmede gepaard gaande een trommelvuur van ironische motieven. Een ongewoon vuur kwelt den god van het zonnevuur ; het oog, dat de gansche wereld omvat, is gericht op één enkel meisje; om haar langer te kunnen zien, verwijlt hij langer aan den hemel; door liefdeszwijmel verduistert hij soms en is bleek van kleur. De dichter speelt met den verliefden god, en hij speelt met de dupliciteit van den god, zonnelichaam en persoonlijke zonnegod tegelijk : verschijnselen aan het zonnelichaam worden als reacties voor. gesteld van zeer persoonlijke gevoelens van den zonnegod: zoo worden op speelsche wijze het lengen der dagen verklaard, alsmede de zonsverduisteringen, naar welker ware verklaring de dichter verwijst door deze te ontkennen. Deze speelsche motieven worden verder in den vorm eener apostrophe gegoten, die er op gelukkige wijze een levendig karakter aan geeft en de ironie ervan onderstreept (H e inze p. 65 ziet er niets geringers in dan hymnenstijl, een episch 
kunstmiddel, dat Ovidius aanwendde op autoriteit van Vergilius!). Of en in hoeverre deze passage Ovidius' persoonlijk eigendom is, leert ons een beschouwing der afzonderlijke motieven.

1. $\quad$ quid nunc, Hyperione nate, 192

forma colorque tibi radiataque lumina prosunt?

Het motief, dat de goddelijke voortreffelijkheden den verliefden god niet baten, was bij de Alexandrijnen blijkbaar in zwang. Apollo, op Daphne verliefd, wordt door zijn eigen orakels in den steek gelaten; zijn geneeskunde faalt $(1.491$; 524). De vorm der apostrophe is daarbij geliefd : naar alexandrijnsch voorbeeld (zie "Admetus") roept Tibullus uit (Apollo verliefd op Admetus) : Delos ubi nunc, Phoebe, tua est, ubi Delphica Pytho? (2.3. 27). Nonnus richt een reeks ironische vragen tot Bacchus, verliefd op Beroë :

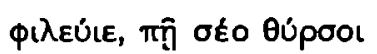

đ̛́

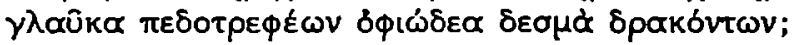

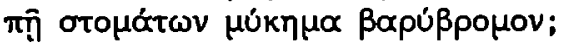

2. nempe, tuis omnes qui terras ignibus uris, 194 ureris igne novo.

Wel ontleend aan een alexandrijnsche beschrijving van Sol's verliefdheid op Clymene (de moeder van Phaethon). Van Helios, op Clymene verliefd, merkt Nonnus op :

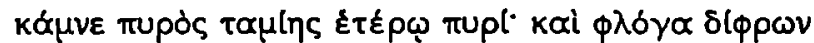

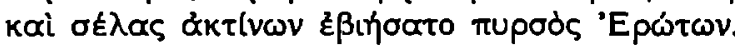

Men vergelijke nog van denzelfden dichter :

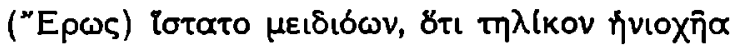

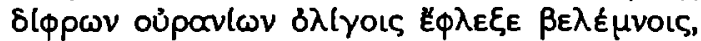

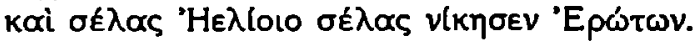

en

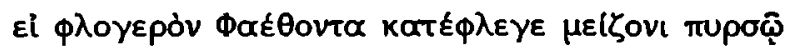

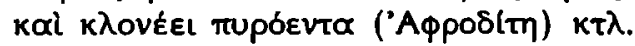

Daar Clymene de bekendste liefde is van Helios, even spreekwoordelijk als Semele's Endymion (33.138), denkt Nonnus in de laatste twee passages ook wel aan Sol's liefde tot Clymene.

3. quique omnia cernere debes, 195

Leucothoen spectas et virgine figis in una, quos mundo debes oculos.

Een soortgelijke opmerking over den verliefden Zeus, wiens oog de badende Semele bespiedt, maakt Nonnus :

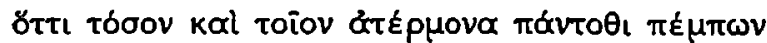

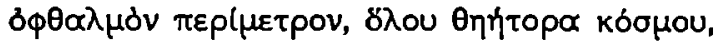

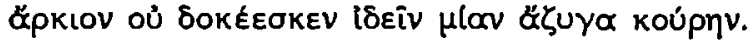

Daar Sol, mundi oculus (228), tot zulk een opmerking noodde, zal Ovidius 
wel niet de eerste geweest zijn, die ze maakte (men vergelijke nog Ovid. 2.32 Sol oculis iuvenem, quibus adspicit omnia, vidit; over het oog van Zeus zie nog Nonnus 5.609 en vooral 7. 190 v.)

$$
\begin{aligned}
& \text { 4. modo surgis Eoo } 197 \\
& \text { temperius caelo, modo serius incidis undis } \\
& \text { spectandique mora brumales porrigis horas. }
\end{aligned}
$$

Dit motief stamt stellig uit de beschrijving van Sol's liefde tot Clymene, blijkens Lucianus en Nonnus. Bij Lucianus verwijt Aphrodite aan Eros: tòv "H $\mu \varepsilon$ vov $\pi \hat{s}$ i $\pi \pi \alpha \sigma$ las (dial. deor. $12 ; \mathrm{K} \mathrm{n}$ a a ck p. 25). Nonnus laat Bacchus die van den aanblik van Beroë niet verzadigd kan raken, aan Helios vragen om den

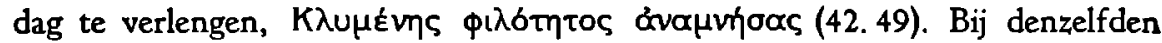
dichter brengt Zeus, hunkerend naar Semele, als de dag geen einde schijnt te willen nemen, dit in verband met naijver van Helios, die wellicht zelf op haar verliefd is, (7. $289 \mathrm{vv}$.), om hern dan tot spoed op te wekken :

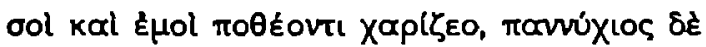

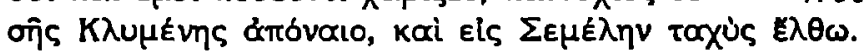

5. deficis interdum, vitiumque in lumina mentis 200 transit et obscurus mortalia pectora terres.

Zonsverduistering als gevolg van smart en rouw van Sol is ons uit „Phaethon" bekend, en wellicht een alexandrijnsch motief; de atmospherische reactie van Aurora, rouwend om haar zoon, in boek 13 (581 v.) is volgens $\mathrm{Eh} \mathrm{wald}$ (t.p.) van alexandrijnschen oorsprong. Nieuw schijnt te zijn, dat de zonsverduistering aan gevoelens van liefde en verlangen te wijten is. Op de reacties van Sol in zijn eigen "Phaethon", of in dien van hemzelf en van zijn alexandrijnsch voorbeeld, wijst Ovidius in "Leucothoe" nog met :

nil illo fertur volucrum moderator equorum 245 post Phaethonteos vidisse dolentius ignes.

6. nec, tibi quod lunae terris propioris imago 202 obstiterit, palles: facit hunc amor iste colorem.

Dit speelsch besluit is wel aan Ovidius' eigen brein ontsproten, want palleat omnis amans : hic est color aptus amanti (Ars 1. 729).

De meeste motieven zijn dus of wel van alexandrijnschen corsprong of wel op alexandrijnsche leest geschoeid. Het is daarom in zijn algemeenheid niet waar, zooals $\mathrm{E} \mathrm{hwald} \mathrm{(ad} \mathrm{194)} \mathrm{beweert,} \mathrm{dat} \mathrm{deze} \mathrm{speelsche} \mathrm{boutade} \mathrm{het} \mathrm{eigendom} \mathrm{is}$ van Ovidius' rhetoriek. Ovidius' eigendom is de concentratie en afronding der motieven, en de geconcentreerdheid der ironie in de afzonderlijke motieven (waarbij de rhetoriek hem ongetwijfeld waardevolle hulp verleende). De volgehouden apostrophevorm, die het effect van de motieven wezenlijk vergroot, is niet in het algemeen, maar waarschijnlijk wel hier aan deze motieven Ovidius' eigendom en merite. En niet onwaarschijnlijk komt op zijn rekening de transpositie van verschillende motieven uit een alexandrijnsch Phaethongedicht naar 
dat van Leucothoë : in "Phaethon" had Ovidius voor deze motieven geen geschikte plaats ; in "Leucothoe" daarentegen, waar Sol van liefde blaakt, waren ze meer dan welkom. Ovidius zet zijn bronnen naar eigen hand.

Er volgt nog een kleine cataloog van vroegere geliefden van Sol (die nu afgedaan hebben); vier worden er genoemd, spelenderwijs; zij moeten den indruk wekken, dat de dichter een willekeurige greep doet uit een overvloedig materiaal ; hij spreekt zelf van multae (208). Ook Sol mag dus in eroticis op een respectabelen dienst bogen. In de gansche Metamorphosen worden aan Sol's amours geen honderd verzen gewijd, doch hun qualitatieve voortreffelijkheid vergoedt ruimschoots hun quantitatieve geringheid, zooals $R$ and (p. 62) Amerikaans opmerkt : „Old Sol enters the field for a display of epic valor, -

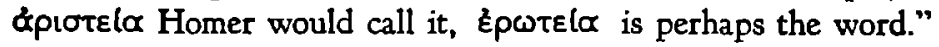

De schildering van Sol's avances begint met enkele verzen over het nachtverblijf en het voeder zijner paarden. Ehwald, ter plaatse citeerend wat Alexander Aetolus over de weiden van Sol's paarden weet te berichten, wijst op het alexandrijnsch karakter ervan. Het is misschien mogelijk iets concreter te zijn in de aangave van herkomst. Het is niet uitgesloten, dat Ovidius, hier zooals in de schildering van de liefdessymptomen, motieven uit den alexandrijnschen Phaethondichter heeft getransponeerd. Dat de verzen een verwijzing inhouden, laat hun refereerende toon vermoeden:

axe sub Hesperio sunt pascua Solis equorum: 214

ambrosiam pro gramine habent; ea fessa diurnis membra ministeriss nutrit reparatque labori.

In „Paethon” vernemen wij terloops, dat Sol's paarden weer ten arbeid tijgen, ambrosiae suco saturos (2.120). Wat daar, uitvoerig geschilderd, de handeling zou hebben opgehouden, is hier een geschikt uitgangspunt voor de intrigue.

In de geciteerde verzen is sprake van ministeria, zooals in "Phaethon" van Sol's officium tegenover de wereld (2.385). Thans echter gaat deze officieele persoonlijkheid, „terwil de nacht haar beurt volbrengt”, zich aan een particulier genoegen wijden, en wel treedt hij het bemind vertrek binnen, vermomd als de moeder der schoone, die temidden van slavinnen bij lampelicht zit te weven. Met nauw verholen ironie worden de manoevres van den god beschreven :

ergo ubi ceu mater carae dedit oscula natae, 222

.res' ait 'arcana est : famulae discedite, neve eripite arbitrium matri secreta loquendi.'

Aan scenes van imitatie en dubbelzinnigheden kan Ovidius zich nimmer genoeg doen. Sol's liefdesverklaring

,ille ego sum', dixit 'qui longum metior annum, 226

omnia qui video, per quem videt omnia tellus, mundi oculus: mihi crede places.'

is een verrukkelijk mengsel van goddelijk-epische plechtstatigheid, en gewoonmenschelyke conversatie; de laatste woorden herinneren aan het bekende elige cui dicas 'tu mihi sola places' (Ars $1.42 ; \mathrm{Ehwald}$ ). Wij verwachten, dat er 
geweld zal volgen; doch als de god zich in zijn ware gedaante openbaart, victa nitore dei posita vim passa querella est (233). Eenzelfde variatie op het thema der overweldiging vinden wij later in "Pomona"; komt zij op rekening van Ovidius zelf? Leucothoë betuigt haar vader, niet geheel overeenkomstig de waarheid : ille Vim tulit invitae (238 v.).

In de beschrijving van Sol's ingrijpen, als Leucothoë door haar vader levend begraven is, speelt het persoonlijk en het zakelijk moment in Sol weer dooreen : hij bevrijdt haar door den grond met zijn stralen te verstrooien (241), en met zijn stralen tracht hij haar de levenswarmte terug te geven (247). De motieven zijn persoonlijk, de acties zijn die van het zonnelichaam aan den hemel. - Sol verandert Leucothoë in de wierookplant; zijn bedoeling hiermede wordt verklaard door zijn opmerking : tanges tamen aethera (251), als wierook namelijk ; wat een uiting lijkt van smart, is in feite een vondst van 's dichters esprit. De woorden herinneren echter tevens aan de catasterismen van geliefden der goden; van Hyacinthus wordt gezegd, dat Apollo hem, had de knaap langer geleefd, in aethere zou geplaatst hebben (10.162).

De schildering van Sol wordt dus gekenmerkt door ironie en het spel met de dupliciteit van zijn wezen. Het is aan geen twijfel onderhevig, dat Ovidius in „Leucothoë" motieven heeft getransporteerd uit een alexandrijnsch Phaethongedicht. Deze transpositie wordt stellig bevredigend verklaard hiermede, dat de motieven Ovidius in "Phaethon" niet, hier daarentegen zeer goed schikten. Daarbij komt misschien, dat Ovidius door zijn bron voor "Leucothoe”" in den steek gelaten werd. De meeste motieven van dit verhaal zijn namelijk zoo bekend en gebruikelijk, dat men geneigd is aan te nemen, dat Ovidius dit verhaal op de basis van minimale gegevens, de hoofdlijnen der intrigue en de namen, (welke zijn bron dan ook is geweest, de Hesiodeische vrouwencataloog, zooals R a p p bij Roscher s.v. Helios Sp. 2017 meent, dan wel een alexandrijnsch zegsman, zooals $\mathrm{E} \mathrm{hwald}$ ad 167 te verstaan geeft) zelfstandig heeft ontwikkeld en uitgebouwd, zooals hij dit ook in "Pomona" doet. Bekende motieven, buiten de reeds genoemde, zijn : het meisje, temidden van dienstmaagden spinnend en wevend (Terentius Heaut. 275, naar Menander; Tibullus 1.3. 83 vv.; Propertius 3.6.15 vv.), door Ovidius ook op eigen gezag in "Lucretia" verwerkt (Fast. 2.743 vv.; E h w ald ad 218); - ipse timor decuit (230), een opmerking naar alexandrijnschen smaak, die wij bij Ovidius in alle toonaarden terugvinden (E hwald ad 1.527); - de hardvochtige vader, ferox inmansuetusque (237), crudus (240; vgl. durus pater, Am. 1.15.17; Met. 9.556 ; patris asperitas,

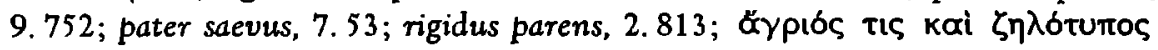
$\gamma \hat{\varepsilon} \rho \omega v$, Lucian. dial. d. mar. 12). De geknakte Leucothoë wordt met evenveel liefde geteekend als de verslagen Coronis in het gelijknamige verhaal. Aan Apollo in "Coronis" en in "Hyacinthus" herinnert Sol door zijn bemoeiingen om het meisje te redden. De schildering van de wegkwijnende Clytie herinnert aan soortgelijke scenes. Ehwald (ad 262) verwijst naar Orpheus (10.74 v.), Castiglioni (p. 178 v.) plaatst Orpheus, Clytie, Cyparissus en Byblis naast elkaar. De twee woorden nympharum inpatiens (260) zijn voldoende om den lezer het bekende motief voor den geest te roepen van de vruchteloos troostende 
nymphen, zooals wij dat uit „Byblis” kennen (9.652 vv.; ook Nicander bij Anton. Liber. 30. 4.).

\section{SALMACIS (IV 285-388)}

Over Ovidius' verhouding tot de halfgoden des velds merkt S ella r (p. 351) op : "The 'semidei', the Fauns and Nymphs with their human sensibilities and their life fused in the woods and groves, have a charm which does not belong to his representation of the greater gods. His imagination is more at home in their forests than in the celestial spheres." Deze opmerking is slechts ten deele juist, en behoeft een belangrijke modificatie. Juist is, dat Ovidius een groote genegenheid heeft voor deze luchtige wezens van bosch en plas, en ook zee. Dit geldt van de mannelijke, van de Faunique Satyrique et monticolae Silvani (1.193), de ruricolae, silvarum numina, Fauni Et Satyri fratres (6.392 v.), jagend achter de nymphen (vgl. 9.347; 11.153 ; zie vooral „Pomona"), onder wie speciaal de groteske alcoholist Silenus genoemd moet worden (4.26 vv.; 11.90); doch heel bijzonder van de bekoorlijke nymphen. Het is voor Ovidius reeds een genoegen op zich, haar verschillende soorten op te sommen (naides et dryades, $11.49 ; 6.453$; vgl. nog $3.402 ; 6.15$ v. ; 14.326 vv.), en met een zekere voldoening en gretigheid constateert hij haar aanwezigheid op italischen bodem. Reeds in de Amores vermeldt hij, dat er in de Anio tallooze nymphen huizen (tu centum aut plures inter dominabere nymphas: Nam centum aut plures flumina nostra tenent, 3.6.63 v.), en in de Fasti, als hij de farce vertelt van Juppiter, Juturna en Lara, roept hij met Juppiter alle Latijnsche nymphen bijeen (2.589), omnes Tiberinides udae, 2uaeque colunt thalamos, Ilia diva, tuos. (597 v.). Hetzelfde geldt van de Metamorphosen : Pomona is bekend onder de Latinas - hamadryadas (14.623 v.); Naides Ausoniae helpen Venus (14. 786); zijn de halfgoden des velds verzot op Pomona, Picus, de schoone Picus, is de afgod van alle Latijnsche nymphen: ille suos dryadas Latiis in montibus ortas Verterat in vultus, illum fontana petebant Numina, naiades (14. 326 vv. ; volgt een opsomming van Latijnsche rivieren). Canens, de dochter van Venilia en Janus, wordt onder Ovidius' handen tot een nymph (14. 333). Hij zal ook niet licht de gelegenheid verzuimen, ons deze charmante wezens met een enkel vers voor den geest te roepen, opduikend uit het water (gurgite quae medio summa tenus exstitit alvo, 5.413), of vol nieuwsgierige bewondering (6.14 vv.), of spelend met den Gorgokop (4. $747 \mathrm{vv}$ ), of ook troostend (teneris ulnis trachten zij Byblis op te tillen, 9.652), of ook vooral - typische doch nimmer vermoeiende beelden - dansend (saepe sub hac dryades festas duxere choreas, 8.746 vv.; festas duxere choreas, 8.582 ; ad numerum motis pedibus duxere choreas, 14. 520 ; illae virgineis exercent lusibus undas, 14.556), of zwernmend (Doridaque et natas, quarum pars nare videtur, 2.11 ; placidisque natant Nereides undis, 13.899), of ook, zeer charmant, de haren drogend (pars in mole sedens viridis siccare capillos, 2.12; iniectos umeris siccantem sole capillos, 11. 770; rorantesque comas a fronte removit ad aures, 5.488 ; viridesque manu siccate capillos, 5. 575). Doch S ell a r is onjuist, als hij meent, dat Ovidius in het uitbeel- 
den dezer wezens zich bepaalt tot de natuur en de sfeer van het ongerepte woud. Integendeel, Ovidius vermeit zich in fantasieën, waarin de nymphen de zegeningen der civilisatie kennen. Hij oppert de veronderstelling in een vergelijking van boek VI : ecce venit magno dives Philomela paratu, Divitior forma, quales audire solemus Naidas et dryadas mediis incedere silvis, Si modo des illis cultus similesque paratus (451 vv.). Doch het blijft niet bij een veronderstelling. Wij hooren van rechtsprocessen, die de nymphen voor den rechterstoel van een riviergod uitvechten (1.576); in "Pieriden" (zie daar) vormen de nymphen een formeele jury van gezworenen. Hun rouw beperkt zich niet tot natuurlijke tranen; zij wijden, als echte menschenkinderen, een gestorven broeder een haarlok (planxere sorores Naides et sectos fratri posuere capillos, 3.505 v.) en kennen het instituut rouwkleeding: cum vestibus atris wordt gezegd van menschenkinderen als de dochters van Niobe (6.288), Progne (6.568), Althaea (8.448), doch ook van de dryaden, die na den moord op een harer zusteren zich om wraak wenden tot Ceres (8.778), terwijl boek XI ons vertelt van zwartomzoomde kleeren (obstrusaque carbasa pullo Naides et dryades passosque habuere capillos,

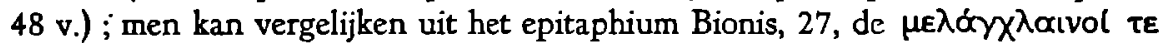
Пpırimot. Wij hooren van nymphen, die rusticae zijn, als Daphne en Callisto, geen zorg bestedend aan haar uiterlijk $(1.477 ; 2.412 \mathrm{v}$.), doch ook van een nymph, die in dat opzicht bekeerd is, Arethusa (zie daar). Nymphan, in charmante, landelijke dracht (nudae vestigia, 8.571; ritu succincta Dianae, - fusis utrimque capillis, 9.89 v.) dienen bij Achelous een luisterrijk, modern diner op. De nymphen, die Diana verzorgen, zijn welgetraind; een speciale vermelding verdient de ormatrix (zie „Actaeon"). Aan de ornatrix uit het Augusteische Rome worden wij ook herinnerd in het verhaal van Galatea. Deze Nereide droogt niet eenvoudig en eigenhandig haar lokken, doch maakt van Scylla's diensten gebruik: cui dum pectendos praebet Galatea capillos (13.738). Aan Scylla vertrouwt zij ook de geheimen van haar hart toe, zooals dat de puellae te Rome niet zelden deden. Herinnert het geciteerde vers reeds formeel sterk aan dat der Ars (at non pectendos coram praebere capillos, 3.235 ; vgl. uit de Heroides: nec mihi pectendos curast praebere capillos, 13.31), daarbij komt, dat de schildering van het vertrouwelijk gesprek der beide meisjes (Scylla elusos iuvenum narrabat amores, 737; Galatea, repetens suspiria, 739, van haar beminden Acis en haar minnaar Polyphemus) herinnert aan het tafereel van meesteres en kamenierster uit de Ars : hanc matutinos pectens ancilla capillos Incitet et velo remigis addat opus Et secum tenui suspirans murmure dicat etc. (1.367 vv.). De verklaring van de levendige, liefdevolle details in deze scene, die, compositorisch gezien, slechts het raam is voor een vertelling, is : Rome, meesteres en ornatrix.

Deze sfeer der elegie ademt vooral de schildering van de nymph Salmacis, uiterst ijdel en verfijnd, opgaande in haar schoonheid en de verzorging ervan, waarlijk een cultissima femina (Ars 1.97). $\mathrm{Zij}$ is, naar een woord van $\mathrm{R} \mathrm{ibbeck}$ (p. 302), geteekend naar het model eener Romeinsche puella : 
sed modo fonte suo formosos perluit artus, 310

saepe Cytoriaco deducit pectine crines

et, quid se deceat, spectatas consulit undas;

nunc perlucenti circumdata corpus amictu

mollibus aut foliis aut mollibus incubat herbis.

De details zijn aangepast aan haar staat van bronnymph, doch overigens laat zich deze passage het gemakkelijkst commentarieeren met citaten uit de wereld der elegie. Ehwald (ad 311) merkt op, dat zij handelt volgens de opmerking der Ars: huic decet inflatos laxe iacuisse capillos, Illa sit adstrictis inpedienda comis (3.145 v.). Ik zou willen wijzen op de treffende parallel in hetzelfde boek der Ars : munditiis capimur : non sint sine lege capilli; admotae formam dantque negantque manus; Nec genus ornatus unumst: quod quamque decebit, Elegat et speculum consulat ante surm (133 vv.). In perlucenti amictu is wel een zinspeling te zien op de befaamde ragfijne Coae vestes (cf. femineum lucet sic per bombycina corpus, Martial. 8. 68. 7 ; Cois tibi paene videre est Ut nudam, Hor. 5. 1.2.101/2). Terecht noemt $R$ ibbeck haar een ware hetaere; in begeerte tot Hermaphroditus ontvlamd, gaat zij niet eerder op hem toe,

etsi properabat adire, 317

quam se composuit, quam circumspexit amictus

et finxit vultum et meruit formosa videri.

Zoo heet het in de Amores : ornatast : dotes exhibet ipsa suas (2.4.38). Haar geheele verschijning kan worden samengevat in het vers, door Ovidius gewijd aan de verpersoonlijking van het minnedicht, Elegeia : forma decens, vestis tenuissima, vultus amantis (3.1.9).

Wij hebben hier dus te doen met een zeer sterk geval van moderniseering in de nymphenwereld. Voor Salmacis bestond hiertoe een bijzondere reden : haar bron stond in den roep, hen, die er in baadden, te verwijven; hierom wordt de nymph geschilderd als ijdel en wulpsch, ja het woord verwijfd is bij dit specimen van het vrouwelijk geslacht niet misplaatst. Doch, vroeg het verhaal van Salmacis als het ware om moderniseering, dit geval staat, zooals is aangetoond, in de nymphenwereld volstrekt niet alleen. Niet slechts in de hemelsche spheren, niet slechts in de onderwereld (zie „Ino" en „Roof van Proserpina"), doch ook in de wereld der natuurwezens bij uitstek schildert Ovidius met de moderne kleuren van zijn stad.

$$
\text { INO (IV 416-562) }
$$

De sage van Ino en Athamas was veelvuldig behandeld, doch over een eventueel episch voorbeeld van Ovidius kunnen wij niets zeggen ( $E \mathrm{~h}$ w ald ad 416 en 420). Ovidius heeft het verhaal episch vitgewerkt, daarbij stellig ook te rade gaande bij eigen werk en bij Vergilius' Aeneis, zooals wij zullen zien. Wij moeten behandelen het optreden van Juno, de schildering der Onderwereld, de actie der Furie en het onderhoud tusschen Venus en Neptunus.

Een monoloog van Juno opent de handeling. $Z_{i j}$ vat de successen van Bacchus samen, en stelt daartegenover haar eigen onmacht. De waanzin, waarmede 
Pentheus door Bacchus geslagen werd, wijst haar den weg der wraak; door waanzin zal zij de triumphantelijke Ino in het verderf storten; hierop begeeft zij zich naar Tisiphone. Haar monoloog heeft dus ten doel de actie op gang te brengen, doch tevens is hij in zijn felheid even typeerend voor het rancuneus karakter der godin als de ontboezemingen in "Callisto" en „Semele". De achtergrond van den monoloog vormt Juno's monoloog in Aeneis VII, waarmede de actie der hemelkoningin geopend wordt tegen de in Italië gelande Trojanen. Daar stelt zij Mars' en Diana's succesvol optreden tegenover haar eigen onmacht (304 vv.) en besluit de helsche Allecto in haar plannen te betrekken. Doch door de overeenkomsten komen de verschillen des te meer uit. Bij Vergilius gaat het om niets minder dan het falen harer wereldpolitiek, die erop gericht is, het groote imperium, aan Aeneas' nazaten beloofd, te voorkomen. Bij Ovidius daarentegen wordt zij gedreven door een wilde rancune tegen den zoon der bijzit en hen, die in zijn glorie deelen. Ino wordt door den dichter omschreven als matertera novi dei (417); in die hoedanigheid moet zij het ontgelden. De godin zelf omschrijft Bacchus veelzeggend met de paelice natus (422). Blijft bij Vergilius Juno, ondanks haar hartstochtelijkheid, de verheven, majestueuze, indrukwekkende hemelkoningin, magna Iovis coniunx (308), bij Ovidius woedt zij in bijna duivelsche hysterie om haar inulti dolores; zij spreekt simpelweg van Iuno (426). Bij hem ook geen statige zinnen, doch drie korte, bittere vragen, snel op elkaar volgend. $\mathrm{Zij}$ smult van de gedachte, die in haar is opgekomen : cur non stimuletur eatque Per cognata suis exempla furoribus Ino? (430 v.).

Bij Vergilius gaat zij na haar monoloog naar de aarde, en ontbiedt daar uit de onderwereld Allecto. Bij Ovidius gaat zij zelf naar de onderwereld, zoo is zij van haat vervuld : de dichter constateert het zelf : sustinet ire illuc caelesti sede relicta (Tantum odiis iraeque dabat) Saturnia Iuno (447 v.). Pallas, ondanks haar verbolgenheid, betreedt de woning van Invidia niet, neque enim succedere tectis fas habet (2.766/7), doch Iuno daalt zelfs in de onderwereld af in haar rancune. Om haar wraak te bevredigen laat zij zich door Cerberus aanblaffen (450). In Saturnia Iuno, deze hoog-epische formule, door Ennius gevormd, door Vergilius gesanctionneerd, door Ovidius enkel in deze passage gebruikt (elders vindt men slechts Saturnia substantive), proeft men de ironie en 's dichters commentaar. De drempel zucht onder haar sacrum corpus (449), de Eumeniden rijzen eerbiedig voor haar op : het teekent de majesteit, die haar eigenlijk aankleeft, doch onderstreept tevens het onkoninklijke, ongoddelijke, en wegens de motieven kleinzeerige van het bezoek. Met norschen blik neemt zij de verdoemden op, in het bijzonder, zoo zegt de dichter, Ixion. Dit past uitstekend bij Juno, want Ixion had haar matrone-eer willen schenden, Juno's gevoeligste punt; zij zal alles doen om Juppiter een van zijn streken thuis te bezorgen, op één voorwaarde : dummodo casta (Fast. 5.242). Haar woorden tot de Eunieniden worden in de indirecte rede weergegeven; een nieuwe directe indigiatio zou te veel zijn en de werking van haar monoloog aan den aanvang van het verhaal schaden. Doch Ovidius weet van deze gedwongen indirecte rede profijt te trekken : imperium, promissa, preces confundit in unum Sollicitatque deas (472 v.). Ook hierbij kunnen wij aanteekenen : tantum odiis iraeque dabat. Bij 
Vergilius geeft Juno aan Allecto enkel baar imperium; de koningin des hemels verlaagt zich tegenover een helsche furie niet, zooals tegenover Aeolus, tot promissa, laat staan tot preces. Pallas geeft bij Ovidius Invidia slechts een bevel, zonder een belooning in het vooruitzicht te stellen. Iuno echter neemt hier alle middelen te baat; niets is haar te min. Ja, zoo merkt de fijnproever der rhetoriek fijntjes op, zij is zoo buiten zichzelf, dat zij de regelen der kunst met voeten treedt : zij had volgens het schema imperium, promissa, preces moeten werken; dan had zij een even fraaien climax kunnen bereiken, als Tellus (zie „Phaethon”) of Latona (zie "Lycii coloni”) of Aurora (zie „Aurora") wisten te bereiken. Doch neen, confundit in unum. $\mathrm{Zij}$ is door het dolle heen. Tisiphone vat haar woorden kernachtig samen : non longis opus est ambagibus (476). (Ovidius speelt hier ook met de aanbidding der alleenzaligmakende rhetoriek der declamatiezalen. Hij weet, dat de natuur sterker is dan de leer.) Het schijnbaar nuchtere referaat zegt ons meer over Juno dan een directe expectoratie van vijftig verzen had kunnen doen. Doch Ovidius heeft hiermede nog niet al zijn pijlen op Juno afgeschoten : zij verlaagde zich er toe zelfs tot in het verblijf der verdoemden af te dalen; Tisiphone geeft haar den raad caelum melius (478) weer op te zoeken. En Juno, wetend, dat de wraak in vertrouwde handen is, keert laeta naar den hemel terug. Iris, haar gedienstige, „besprengt die Göttin, die froh der gesicherten Rache, und ohne der Befleckung zu achten, die sie sich durch ihren Gang in die Unterwelt zugezogen hat, in den Himmel eintreten will, mit reinigendem Wasser, damit sie nicht die Götterwohnung entweihe." (E h wald ad 479). De koningin des hemels heeft een miasma over voor haar wraak. Ovidius vermenschelijkt de godin dus in sterke mate, hij wijst op het contrast tusschen haar goddelijke waardigheid en haar feitelijk kleingeestig gedrag, en drijft den spot met haar onbeheerschtheid.

Uitvoerig wordt de Onderwereld beschreven. De weg, die daarheen voert, is omschaduwd door taxusboomen, symbolen van rouw en dood; het is er doodstil ; het landschap is triest en doodsch. Alles is afgestemd op het begrip "dood", zooals in een personificatie van Invidia alles op het begrip "afgunst" is afgestemd. Traditioneele autributen, als bijv. Charon, worden weggelaten; dat de nevelen van den Styx vermeld worden, geschiedt enkel om de lugubere, doodsche sfeer te versterken. Alle geographische aanduiding omtrent het begin van den weg ontbreekt, ofschoon Ovidius zeer wel weet, dat dit volgens de traditie de Taenaria porta is (10.13, vgl. Verg. Georg. 4. 467). Ovidius ignoreert dus welbewust de traditioneele voorstelling van zaken, en geeft zijn eigen fantasie, die sterk herinnert aan de ekphraseis van volkomen poëtische, niet op mythen teruggaande personificaties. Typisch Ovidiaansch is het veristische trekje, dat de dooden er den weg bijster raken in het doodsche duister.

Iets dergelijks valt ook op te merken omtrent de schildering der Onderwereld zelf, een stad, Stygia urbs (437). De wegen des doods zijn duizend: duizend toegangen heeft de stad dus. $\mathrm{Z}_{\mathrm{ij}}$ neemt de dooden op van alle windstreken en alle tijden : zij is dus ruim. Dreigt er dan niet eindelijk overbevolking? Neen, zij merkt den toevloed niet, zooals dat andere verzamelbekken, de zee, den toevloed niet merkt der rivieren. Tot zoover zijn de bijzonderheden begripsmatig 
en niet mythologisch. In het volgende werkt Ovidius de voorstelling, dat men in het hiernamaals het aardsche leven voortzet, op zijn manier uit. Voor de helden van Homerus beteekende dit de Elyseïsche velden met wijden hemel en glanzend licht, waar de heroische idealen hoogtij vieren, wapenhandel en wagenrennen, worstelen en dansen rond Orpheus. Aldus schilderde ook Vergilius nog de traditioneele zalige dreven. Hij was hierin wel eenigszins anachronistisch, want andere tijden, andere idealen en wenschdroomen. Tibullus had de Elyseische velden reeds aan zijn omstandigheden en wenschen aangepast (1.3.57 vv.): minnaar van het land en de liefde, maakte hij er een idyllisch paradijs van, dat in het teeken van Amor staat. Tibullus' veranderingen vallen niet zoozeer in het oog, omdat bij hem de velden de velden blijven. Ovidius echter, de stedeling en de dichter der stedelingen, modelleert zijn Onderwereld naar de verlangens der stedelingen. Het eldorado der Homerische helden lokt den modernen mensch niet meer. Hij moderniseert daarom de achterhaalde voorstellingen, zooals hij de luxe van Circe, door Homerus beschreven, moderniseert (zie „Circe”). De Onderwereld is een stad, en de gelukzaligen genieten er hun oude stadsleven; zij frequenteeren bijv. het forum en leggen beleefdheidsbezoeken af (444 v.); dit zijn de antiquae imitamina vitae (445) van den modernen mensch (cf. nos fora viderunt pariter, nos porticus omnis, Nos via, nos iunctis curva theatra locis, Ex. P. 2. 4. 19/20). Ovidius' schildering wekt een frivolen en zelfs cynischen indruk. Wil hij spotten, en waarmede dan? Met de naieve opvattingen over het hiernamaals? Of spot hij met de frivoliteit van zijn eigen tijd? In beide verklaringen ligt een zekere waarheid, doch het voornaamste moment is wel het simpele plezier in het aardige idee van de moderne toepassing van het oude princiep, de verrassing van het contrast, en de amusante details. Elders (Ibis 173) vermeldt Ovidius de traditioneele Elyseische velden, doch hier schildert hij de onderwereld deels naar het begrip ,dood”, deels naar Rome's beeld en gelijkenis, zonder eenig compromis met de details der traditie. Deze moderne Onderwereld is de tegenhanger van den modernen Olympus, in boek I geschilderd; in beide gevallen wijkt de salon-dichter bewust af van den verheven ziener Vergilius: Ovidius wenscht niet grootsch, hij wenscht slechts modern te zijn.

Eenzelfden geest ademt zijn beschrijving van het verblijf der verdoemden. $\mathrm{Bij}$ Vergilius (6.548/627) verblijven zij in een geweldige strafvesting, omgeven door een drievoudige muur en den Phlegethon. De ingang wordt gevormd door een enorme poort met stalen zuilen, waarboven zich een ijzeren toren verheft. $\mathrm{Z}_{\mathrm{ij}}$ wordt bewaakt door de wrekende Tisiphone, die in al haar vreeselijkheid geteekend wordt. Huiveringwekkend is het gekerm, zweepgeknal en ketting. gerammel. Slachtoffers zijn verschillende categorieën van menschen; als befaamde misdadigers noemt Vergilius bij name de Titanen en Aloiaden, Salmoneus, Tityos, Ixion en Pirithous, Theseus, Phlegyas. Tegen Vergilius steekt Ovidius scherp af. De strafvesting, Sedes Scelerata geheeten (456) is een deel der Stygia urbs, waarin als het ware per definitionem alle dooden thuis hooren. Het is een kerker, met stalen deuren (het eenige detail van het uitwendige, door hem uit Vergilius overgenomen: Ov. 453 fores clausas adamante naar Verg. 552 solidoque adamante columnas). De interne organisatie wordt uiterst overzichtelijk gegeven, 
zoodat men bijna zou gelooven met een modelgevangenis te doen te hebben. De Eumeniden zijn er de cipiers. Om het beeld te vervolmaken heeft Ovidius hier den traditioneelen hellehond een plaats gegeven, en wel als ianitor, ofschoon hij eigenlijk aan het begin van de geheele Onderwereld thuishoort. Terwijl bij Vergilius alles afgestemd is op het motief discite iustitiam moniti et non temnere divos (620), ontwerpt Ovidius een interessant beeld van de afdeeling Misdaad der Onderwereld. Zonder eenigen huiver, in puntige woorden (bijv. volvitur Ixion et se sequiturque fugitque, 461) geeft hij een opsomming der klassieke boosdoeners. Hij noemt enkel de vijf klassieke boosdoeners, doch hij noemt hen ook alle vijf. Omdat de situatie hier daartoe uitnoodigt, is dit niet bijzonder merkwaardig. Merkwaardig is, dat hij in zijn volledigheid steeds constant is, zie 10.41/4, Ibis 175/82 en 191/4. Dit is des te opmerkelijker, omdat wij deze volledigheid bij geen zijner voorgangers vinden. Bij Lucretius (3.990/1012) ontbreekt Ixion, bij Tibullus (1.3.73/9) ontbreekt Sisyphus, ofschoon beide dichters den indruk wekken een volledige opsomming te geven. Bij Vergilius, wiens keus echter door andere motieven bepaald werd, ontbreken Tantalus, Sisyphus en de Beliden (6.580/618). Bij Propertius (3. 5. 39/46) ontbreken de Beliden (daarentegen worden de Giganten, Alcmaeon en Phineus vermeld); dezelfde dichter laat op een andere plaats (4.11.23/8) Tityos onvermeld. Tantalus en Sisyphus ontbreken bij Horatius (c. 3.11.21 vv.), die overigens op geenerlei wijze volledigheid pretendeert. Zelfs na Ovidius laat een Statius, bij wien de volledigheid een ware plaag pleegt te zijn, een steek vallen (4. 537/9 : in vers 538 mogen wij wel enkel aan Tantalus en niet tevens aan de Beliden denken). Ofwel Ovidius houdt zich strikt aan een overgeleverden canon ofwel hij heeft zich dien zelf gevormd. Niet minder frappant dan de constante volledigheid is het spelend gemak, waarmede Ovidius zijn opsommingen ten beste geeft : geen spoor van moeizaamheid of mechanische productie. Door deze schijnbare moeiteloosheid onderscheidt Ovidius zich gunstig van dichters als Statius of Nonnus.

Hoezeer de horror sacer aan zijn beschrijving van het verblijf der verdoemden ontbreekt, blijkt ook uit de schildering van de Eumeniden in haar thuis. Het is een luguber genrebeeldje, herinnerend aan verzen, waarin geschilderd wordt, hoe Nereiden heur haren drogen (zie onder "Salmacis") : deque suis atros pectebant crinibus angues (454). Hier zijn de Eumeniden huiselijk. Als Tisiphone echter in actie gaat, wordt zij officieel. Zooals Mercurius dan zijn uitrusting aanlegt (zie "Io") en Iris haar duizendkleurig gewaad (zie "Ceyx et Alcyone"), zoo neemt Tisiphone haar traditioneelen bloedigen fakkel, doet haar bloedig kleed aan; als gordel dient een slang. Terug van haar opdracht, sumptum recingitur anguem (511). Wij mogen in deze voorstelling van zaken hier een moment van vermenschelijking zien; dit is echter in het algemeen van secondairen aard. Wij moeten hierin vooral een kunstgreep van den dichter zien, die daardoor gelegenheid krijgt ons een bekend beeld voor den geest te roepen.

Bij de schildering van Tisiphone's actie contamineert Ovidius Vergilius' schildering van de wrekende Tisiphone in Aeneis VI (in haar bloedig kleed, de schuldigen geeselend, in de linkerhand slangen, $555 \mathrm{vv}$.) en het optreden van 
Allecto in Aeneis VII. Tisiphone is vergezeld van Luctus, Pavor, Terror, Insania, personificaties van de uitwerkingen van haar optreden. Bij haar verschijnen trillen de posten, verdoffen zelfs de helgepolijste deuren, de zon vlucht. Als Ino en Athamas verschrikt het huis willen ontvluchten, wordt dit belet door de Erinys, die den drempel belegert. Volgt een virtuooze beschrijving van de Erinys in actie, waarbij Vergilius' beschrijving verbleekt (491 vv.). Daarop rukt zij zich twee haarslangen uit, die zij den ongelukkigen in de borst werpt; deze wonden niet het lichaam, doch den geest, de slangen van den waanzin. Hiermede echter niet tevreden, stort zij hun ook nog een furiale venenum in, waarvan de samenstelling in gruwelijkheid niet te overtreffen valt. „Die Hervorhebung und Schilderung des Grausigen entspricht dem alexandrinischen Charakter der ovidischen Poesie; das hier Ausgeführte ist Ovids eigene Erfindung." (Ehwald ad 500). $\mathrm{Zij}$ roept een beeld op eener Eryniale apotheek, waar de ingrediënten vakkundig gevijzeld, gemengd, gebonden en met toepas selijke instrumenten geroerd worden (men vergelijke Circe's laboratorium in "Circe"). Tenslotte draait zij nog haar fakkel in een snellen kring rond, zoodat er een vuurbol schijnt te zweven. Eerst daarmede is haar werk ten einde. Onmiddellijk maakt zich waanzin van Athamas meester, die in zinsbegoocheling den kleinen Learchus, van moeders borst gerukt, verplettert, hetgeen met de grootst mogelijke aanschouwelijkheid beschreven wordt. Ino, hierdoor in actie komend, stort zich in Bacchischen waanzin naar buiten, snelt een rots op en werpt zich met Melicertes in zee. - Vergelijken wij hiermede Allecto's activiteit bij Vergilius, hoe zij Amata en Turnus bewerkt. Bij Amata geschiedt dit in alle stilte. Ongemerkt laat Allecto haar een der slangen in de borst glijden; tusschen de kleeren en de borsten glijdt deze attractu nullo fallitque furentem (350). Het effect is dan ook niet aanstonds merkbaar, want eerst klaagt zij nog mollius et solito matrum de more (357); doch als dit niet baat, ontsteekt zij in razernij, veinst Bacchischen waanzin, zweept de vrouwen op en doolt met dezen door de wouden. Allecto en haar slang zijn niet veel meer dan een aanschouwelijke aanduiding van het geleidelijk tot hysterie aanzwellende misnoegen van Amata zelf, quam femineae ardentem curaeque iraeque coquebant (345). $\mathrm{Zij}$ maken dit proces poëtisch aanschouwelijk; het kwaad komt echter van binnen uit. Turnus, in zijn slaap op de proef gesteld door Allecto, als Juno-priesteres vermomd, geeft, zeker als hij zich voelt, aanvankelijk geen krimp. Door zijn laatdunkende woorden getergd, ontsteekt Allecto in furiale woede : haar slangen sissen, haar oogen schieten vuur; de beide slangen van heur haar richten zich op; zweepgeknal, bittere woorden; tenslotte stoot zij hem een zwartrookende fakkel in de borst : een ware nachtmerrie. Ontzet springt Turnus op uit zijn slaap, een acute krijgswoede maakt zich van hem meester. Ook hier is Allecto niet veel meer dan de poëtische exponent van het ontstaan der wilde woede bij een man van Turnus' impulsief karakter. Allecto is dus bij Vergilius weinig meer dan de dichterlijke exponent van de activiteit der innerlijke roerselen der ziel; het kwaad komt van binnen uit; mobilitate viget viresque acquirit eundo. Bij Ovidius daarentegen is alles op het uiterlijk effect berekend; het kwaad komt van buiten af. Daarbij wordt zijn schildering gekenmerkt door een exagge- 
ratie van de gruwelijke motieven en door een concentratie van alle denkbare verschrikkelijkheden. Aan zijn contaminatie van de schildering der wrekende Tisiphone uit Aeneis VI en de slang van Amata en de nachtmerrie van Turnus uit Aeneis VII voegt hij nog eigener beweging het waanzinvergif en het fakkelgeslinger. Doch niet enkel Vergilius buit hij uit. In de schildering van den waanzinnigen Athamas benut hij zijn eigen schildering van Pentheus' dood (3. 710 vv.). De zon vlucht bij aankomst van Tisiphone: dit herinnert aan hetzelfde verschijnsel bij het gruwzaam maal van Thyestes. Ovidius stelt zich niet ten doel ons te ontroeren door heiligen huiver, doch ons te verbluffen door een show van zijn kunnen en raffinement. Het religieuze moment ontbreekt bij hem.

Tenslotte de schildering van Venus. Deze vraagt aan Neptunus om de vergoddelijking van Ino en Melicertes. Volgens $\mathrm{E} h$ wald (ad 537) herinnert deze scene aan het onderhoud tusschen Venus en Juppiter in Aeneis I; dit is niet juist; de achtergrond ervan is de scene in Aeneis V, waar Venus bij Neptunus intervenieert voor Aeneas :

Vergilius: at Venus interea Neptunum, exercita curis, 779 adloquitur talisque effundit pectore questus -

Ovidius : at Venus inmeritae neptis miserata labores. 531 sic patruo blandita suo est -

De verschillen tusschen beide dichters zijn echter hoogst opmerkelijk. Bij Vergilius pleit de bezorgde Venus weliswaar voor haar zoon, doch ter wille van zijn zending (si concessa peto, si dant ea moenia Parcae, 798), en zij wendt zich tot den god, die passend omschreven wordt als Saturnius domitor maris alti (799). Bij Ovidius vleit zij (blandita) haar oom (patruo) ten behoeve van haar kleindochter (neptis), waarbij zij niet een beroep doet op verdiensten, doch op medelijden, zooals zij zelf ook van medelijden vervuld is (miserata, 531 ; miserere meorum, 534); zij vraagt het als een persoonlijke gunst. Ofschoon het dus om niets minder dan een apotheose gaat, wordt deze zaak als een familieaangelegenheid behandeld : vermenschelijking. Men vergelijke de apotheose's van Aeneas en van Caesar.

Ovidius heeft dus het verhaal van Ino en Athamas episch uitgewerkt. Daarbij gebruikt hij doorloopend Vergiliaansche scenes als achtergrond, emaar verwijzend en meestal ermede contrasteerend. $Z$ ijn verhaal draagt een alexandrijnsch karakter; wat de godenschildering betreft, wegens de vermenschelijking van Juno, van Venus en in zeker opzicht ook van de Eumeniden, wegens de modernisee. sing van de Onderwereld, wegens een zeker moment van personificatie in de schildering van den weg naar de onderwereld, wegens de ironie en spot, waarmede hij Juno treft; alle religiositeit is verre, het is louter een kwestie van kunst en artistieke voorstelling van zaken.

\section{MEDUSA (IV 794-803)}

Er wordt een korte verklaring gegeven van het feit, dat Medusa slangenhaar draagt. Deze vertelling schijnt $\mathrm{Ehwald}$ (ad 795) aan een alexandrijnsch dichtwerk ontleend te zijn. De verklaring is kras: schending van Medusa door 
Neptunus in den tempel van Minerva! Voor een verklaring dezer krasse verklaring moeten wij de feiten van achteren naar voren lezen; het heeft er althans den schijn van, dat de redeneering alsvolgt is verloopen : Minerva draagt op de borst de schrikwekkende Gorgokop met het slangenhaar ; in het afhouwen van dien kop zal zij daarom wel betrokken zijn geweest; dit geldt echter ook van het ontstaan van het slangenhaar, dat toch geen alledaagsch verschijnsel is. Is zij daarin echter betrokken, dan moet daarvoor een reden geweest zijn. $\mathrm{Nu}$ is het bekend, dat Neptunus een verhouding met Medusa gehad heeft ; Hesiodus reeds (Th. 278 vv.) spreekt erover. In deze verhouding moet Minerva dan alleronaangenaamst betrokken zijn geweest. Verander Hesiodus' $\mu \alpha \lambda \alpha \kappa o ̀ s ~ \lambda \varepsilon \varepsilon \mu \omega \dot{\nu}$, een vrij vage aanduiding, in den tempel van Minerva, en het contact is tot stand gebracht. De verhouding tusschen den god en de stervelinge is voor de godin dan een dubbel affront : het gebeurde in haar tempel, en wel in den tempel van de maagdelijke godin. Waarom veranderde zij Medusa's haren? Omdat Medusa door haar prachtige lokken zoo aantrekkelijk was, er eventueel mee coquetteerde.

De rol, die Neptunus in dit verhaal speelt, is cynisch, zelfs voor een dier

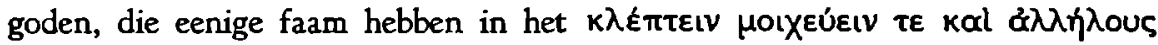
đómarteúetv. Voor een onderzoek naar Ovidius' godenschildering levert deze vertelling echter niet veel op, daar zij daarvoor te schematisch is aangeduid en niet uitgewerkt. Belangrijk is enkel, dat Ovidius er niet voor terugdeinst, een dergelijke, sacrilegische vertelling te refereeren. Dat onder templum niet de omgeving van den eigenlijken tempel, de gewijde grond verstaan moet worden, doch heel stellig de tempel zelf, bewijst de reactie der godin : aversa est et castos aegide vultus - texit : het is de reactie van het godenbeeld, die door de alexandrijnsche dichters niet ongaarne vermeld wordt.

\section{MUSAE (V 254-678)}

Om de Hengstebron te bezichtigen, die door Pegasus' hoefslag ontstaan was en waarvan de faam tot haar was doorgedrongen, brengt Minerva den Muzen op den Helicon een bezoek. B e the (O.N.) heeft in een belangwekkend essay aangetoond, dat Ovidius in het verhalencomplex van de tweede helft van boek $\mathrm{V}$ een verhalencomplex van Nicander benut heeft (deze opvatting bleef niet zonder critiek; de litteratuur bij Schmidt p. 9), en dat hij in de gerefereerde verzen een deel van het verhaal, dat de Muze haar gaat doen, dat van den zangstrijd tusschen de Muzen en de Pieriden, geanticipeerd heeft. Volgens Nicander (bij Anton. Liber. 9) bracht de zang der Muze toehoorders en natuur in extase, de Helicon zwol op ten hemel, totdat op Neptunus' bevel Pegasus met zijn hoef den top insloeg. Bij Ovidius vertelt de Muze wel van haar succes, doch bescheidenlijk, en omdat een beschrijving van Helicon's enthusiasme in den mond van de zegevierende vertelster niet welvoeglijk was, liet Ovidius de schildering daarvan weg uit het eigenlijke verhaal van den wedstrijd. Van het feit echter, door zijn voorganger en voorbeeld vermeld, maakt hij geestrijk gebruik, als aanleiding namelık tot Minerva's bezoek. (B ethe p. 5 v.). Voor 
de lezers van Nicander moet deze vondst een aangename verrassing geweest zijn; is mihi causa viae (258) heet het uitdrukkelijk, - en triomphantelijk; wij hooren er Ovidius' eigen voldoening in over deze geslaagde vondst. Wij hebben hierin een bewijs van Ovidius' zelfstandigheid tegenover een alexandrijnsch voorbeeld. Belangrijk is ook, dat hierdoor vaststaat, dat de schildering van Minerva's bezoek aan de Muzen Ovidius' eigen werk is, dat er geen sprake kan zijn van copieeren of adapteeren van een alexandrijnsch voorbeeld, een belangrijk fragment dus voor het onderzoek naar zijn godenschildering en zijn zelfstandigheid daarin.

Het is een charmante gedachte, dat Minerva het veelbesproken mirabile factum met eigen oogen wil zien. Haar woorden zijn ongedwongen, natuurlijk, in conversatiestijl gehouden, evenals Urania's complimenteuze verwelkoming en antwoord. Allerlei details verlevendigen de schildering. Langen tijd slaat zij de bron met bewondering gade (mirata diu, 264); dan, om zich heen ziende (circumspicit, 265), neemt zij de fraaie omgeving op van dit Muzenheim, met zijn wouden, grotten en bontbebloemde weiden, de Muzen gelukkig prijzend om haar kunst en verblijf beide. Alles is naar het leven geteekend. Een der zusteren vertelt daarop, met een stem, waarin nog de ontroering natrilt (et nondum tota me mente recepi, 275) van haar vreeselijk avontuur met Pyreneus, den snooden belager. Dit geschiedt kort en levendig, niet plechtstatig, doch in keuveltrant; men lette bijv. op de kleine tusschenzinnetjes cognorat enim (280) en imber erat (282). Terwijl de Muze nog spreekt (het doode punt wordt vermeden), klinkt uit de boomen vleugelgeklap en stemmengesnap. Verwonderd kijkt de bezoekster op (suspicit, 296; miranti, 300) en vraagt naar de herkomst der geluiden, die menschelijk lijken. Hierop vertelt de Muze van de vulgaire Pieriden, die haar, den Muzen, een zangstrijd opdrongen. In haar relaas klinkt een aristocratische geshockeerdheid door over de verregaande impertinentie van het plebeissh volkje : turpe quidem contendere erat, sed cedere visum Turpius (315 v.). Sine sorte prior (318), tegen alle regels in, begon de tegenpartij, van alle gevoel voor betamelijkheid gespeend. Het onderwerp van haar zang is godslasterlijk; de Muze refereert het kort, slechts het meest shockeerende citeerend (tevens datgene, waarin de metamorphosen van het verhaal vervat zijn). Voor de uitspraak der jury heeft het plebs geen respect; gematigde woorden der Muzen worden met hoongelach beantwoord en zelfs dreigen de verslagenen met handtastelijkheden. Een afschuwelijke sensatie, deze zangstrijd, voor de fijnbesnaarde Muzen. Deze, met veel égards voor de gast, wenschen haar bezoekster niet te vermoeien en op te houden met een verslag van haar eigen zangbeurt. De verzen, waarin Ovidius dit vertelt, charmant, levenswarm, behooren tot zijn allermooiste :

hactenus ad citharam vocalia moverat ora: 332 poscimur Aonides, - sed forsitan otia non sint, nec nostris praebere vacet tibi cantibus aures....?' 'ne dubita vestrumque mihi refer ordine carmen!' Pallas ait nemorisque levi consedit in umbra.

Musa refert: 'dedimus summam certaminis uni etc. 
Adeldom van manieren en adeldom van kunst gaan hand in hand. $\mathrm{Ehw}$ ald merkt (ad 330) op: „Durch eine Art insinuatio (Quint. 4. 1.48) versucht die Muse in echt rhetorischer Weise dem Vorwurf, dass ihre Erzählung zu lang sei und ermüde, zuvorzukommen." Bij een dergelijke mechanische opvatting van Ovidius' kunst is Higham's opmerking op haar plaats (p. 106 v.): "The laborious scrutiny of sources and influences produces the impression that we can explain a poet by means of scientific formulae. Thus if $\mathrm{H}=$ Hellenistic elements or the Hedonic conception of poetry under which they are grouped, and if $\mathrm{S}=$ the structure, schemata, and sententiae of Rhetoric, we are sometimes asked to believe that the formula $\mathrm{H}_{2} \mathrm{~S}$ thoroughly explains Ovid, - the implication being that it should also explain him away."

De schildering van Minerva's bezoek aan de Muzen, onmiskenbaar Ovidius' eigen werk, wordt dus gekenmerkt door een bijzonder geslaagde levensechtheid en charme der personen. Het is vermenschellyking van de edelste allure, eenig in haar soort in de Metamorphosen; elders prevaleert het klein-menschelijke. De reden voor deze sympathieke schildering ligt echter niet hierin, dat Ovidius elders door zijn alexandrijnsche voorbeelden naar beneden wordt gedrukt, hier echter zijn eigen richting volgt, doch in zijn sympathie voor de Muzen. Deze schildering is een charmante hulde aan zijn Zanggodinnen, de doctae sorores (225), en aan de cultae puellae van Rome, naar wie hij de Muzen schildert, doctae, rarissima turba, puellae die aan corporis bonis paren ingenii dotes (Ars 2.281, 112). Al hebben wij hiervoor geen concrete aanduiding, de indruk is daarom niet minder sterk, dat Ovidius hier de fijnontwikkelde meisjes van Rome tot voorbeeld koos. Ook op andere wizen herinnert de dichter ons aan Rome, het moet althans niet uitgesloten genoemd worden. $\mathrm{H}_{i j}$ herinnert ons met een enkel woord waarschijnlijk aan een bekende beeldengroep der Muzen : Thespiades - deae (310) worden deze genoemd. $\mathrm{E} \mathrm{h}$ wald verklaart dit hiermede, dat in Thespiae, een stad in Boeotië aan den Helicon, de oude zetel van den Muzencultus was gevestigd. Ik geloof, dat de zaak minder onschuldig is. Er was een bekende Muzengroep van niemand minder dan Praxiteles, Thespiades genoemd, - een naam, door Varro (1.1.6.2) verklaard met: Musae a Thespiis Boetiae oppido - die door Lucullus met den Felicitastempel gewijd en ten behoeve van de geheele bevolking in Rome opgesteld was (zie bij R o s cher s.v. Musen, II Sp. 3248 v.) : met Thespiades deae roept Ovidius zijn lezers deze groep voor den geest en vervolgens de herkomst van deze groep uit genoemde stad; de aanleiding daartoe was misschien de omstandigheid, dat het verhaal zich afspeelt op den Helicon, nabij Thespiae. Vervolgens is er de lof der fraaie omgeving, waarin de Muzen leven, de wouden en grotten en bonte weiden. Ook dit geschiedt wel niet zonder bijbedoeling : wij behoeven ons slechts te herinneren, dat de naam van de populaire kunstgrotten musaea was (Plin. n. h. 36.42.154; zie onder „Actaeon”). Een beschrijving der Muzengrot geeft Propertius (3.3.27 v.). Ovidius herinnert dus in de vermelde verzen aan de operosa antra (Prop. 3. 2.14) van zijn eigen tijd.

De schildering van Minerva's bezoek aan de Muzen is dus een welgeslaagd voorbeeld van vermenschelıjking en moderniseering. Om Ovidius' zelfstandigheid naar volle waarde te schatten, moet men nog bedenken, dat dit bezoek slechts 
een raam is om erin vertellingen op te nemen en te bundelen. Wij zouden hem dus niet met recht van bloedarmoede hebben kunnen betichten, indien hij dit bezoek, als enkel een technische kunstgreep van het carmen perpetuum, schematisch had behandeld. Ofschoon het echter enkel een raamvertelling is en ofschoon de dichter op eigen ingenium was aangewezen, heeft hij aan deze schildering van Minerva's bezoek ook een waarde in zichzelf gegeven, geprikkeld, ongetwijfeld, door het ingenieuze van zijn vondst, doch ook, uit sympathie voor de cultae puellae, dichtend met zijn hart.

Thans nog enkele verspreide opmerkingen over details. De gastvrouw wordt met name genoemd, Urania (260). $\mathrm{Zij}$ is niet de vertelster ; deze blijft anoniem, una sororum (268). Waarom wordt Urania met name genoemd als gastvrouw? Urania is de oudste en eerbiedwaardigste der Muzen, en bekleedt als zoodanig een uitzonderingspositie. Hiervan is het volgende een aanwijzing : in Fasti V vergasten de Muzen den dichter op de verschillende afleidingen van den naam Mei. Polyhymnia, door Clio en Thalia gesteund, leiden den naam van Maiestas af, Urania van maiores; Calliope tenslotte geeft in episch-hymnische verzen (Ovidius beschouwt haar als de Muze der epiek) de mythologische verklaring. Als Urania met haar verklaring zal aanvangen, heet het : excipit Uranie : fecere silentia cunctae, et vox audiri nulla nisi illa potest $(55 \mathrm{v}$.). Voeg bij het feit, dat haar de verklaring van Mei uit maiores is toebedeeld en dat zij spreekt over de magna reverentia (57) van weleer voor een grijs hoofd, dit eerbiedig stilzwijgen, en de conclusie is niet vermetel, dat zij als de oudste der Muzen geldt ; - als zoodanig in de Metamorphosen de gasturouw : excipit Uranie (260= Fast. 5.55). Doch is Urania de oudste en eerbiedwaardigste, Calliope is de grootste en voortreffelijkste (prima sui chori, Fast. 5.80), de Muze der epiek, die de mythologische verklaring geeft, en, in de Metamorphosen, als e nobis maxima (662), de woordvoerdster der Muzen is in den zangstrijd. $Z_{i j}$ is ook de aangewezen Muze om aan Minerva verslag uit te brengen. De moeilijkheid is nochtans, dat zij in dat geval haar eigen lof moet zingen. Daarom legt Ovidius het verslag aan una sororum in den mond. Deze blijft anoniem om de aandacht niet af te leiden van de heldin van den wedstrijd, Calliope. Volgens Bie (p. 95/7) is de vaste canon der Muzen en haar vaste werkverdeeling van zeer laten datum, en gingen in den Augusteischen tijd de dichters nog willekeurig te werk. Dit mag in het algemeen waar zijn, het kan echter nauwelijks betwijfeld worden, dat voor Ovidius Calliope de Muze der epiek bij uitstek is.

Wat tenslotte den wedstrijd met de Pieriden betreft : bij Ovidius vormen de nymphen de jury, en wel een formeele jury ; zij strekken niet, zooals $E$ h wald (ad 316) meent, tot stoffeering van dit tafereel, een requisitiet aan de bucolische poëzie ontleend. De termen, waarin Ovidius over haar spreekt, herinneren niet aan de natuur en het eenvoudige land, doch aan de stad en aan Rome : zij leggen een eed af (iurant, 316), nemen op haar gezworenen-banken plaats (317), en geven uitspraak (663). Het aardige is, dat deze details uit de wereld der civilisatie verbonden worden met details uit de natuur, waarin deze wezens thuis hooren : zij leggen haar eed af per flumina (316), de banken zijn facta de vivo saxo. Bij Nicander gaf de natuur spontaan haar oordeel, de nymphenjury van Ovidius 
is hiervoor een substituut (B e th e O.N. p. 5), een eigen vondst van den Romein dus, die gekenmerkt wordt door moderniseering en een zeker spel met de vervlechting van cultuur en natuur.

\section{RAPTUS PROSERPINAE (V 341-571)}

Van dit verhaal vinden wij zoowel in de Metamorphosen als in de Fasti (4. 417 vv.) een uitvoerige versie. Het is $\mathrm{He}$ in ze 's onvergankelijke verdienste (p. 1 vv.) te hebben aangetoond, dat het verschil tusschen beide versies niet enkel berust op zakelijke verschillen, voortspruitende uit het feit, dat in de Metamorphosen gedaanteveranderingen, in de Fasti aetiologische verklaringen ingelascht worden, maar dat er ook een weloverwogen stilistisch verschil tusschen beiden bestaat. Dit contrast nu heeft ook gevolgen voor de godenschildering. Wordt in de Pasti Pluto nauwelijks vermeld, in de Metamorphosen treedt hij sterk op den voorgrond, geschilderd als de machtige raptor, de duistere god van het doodenrijk, de vervaarlijke. Zijn verliefdheid wordt in de Metamorphosen niet geschilderd, doch wel episch verklaard, door het ingrijpen van Venus en Amor; en als doel van hun ingrijpen. wordt opgegeven het uitbreiden van hun heerschappij. Ceres ook wordt als een machtige godin geschilderd in de Metamorphosen, energiek in haar wraak en haar beklag bij Juppiter, geheel in tegenstelling met de versie der Fasti, waar zij vooral als de ongelukkige moeder wordt voorgesteld. Ook zien wij, dat er van Juppiter in de Metamorphosen meer majesteit en kracht uitgaat dan in de Fasti, waar hij niet zoozeer de duider van het recht is, als een vergoelijker, die met gevoelsargumenten opereert. Op dit alles heeft $\mathrm{Heinze}$ terecht gewezen, die ongelukkigerwijze in het vervolg van zijn betoog, wat hij gevonden heeft over de godenschildering hier, generaliseert tot een norm voor de Metamorphosen in haar geheel. De ware toedracht van zaken is nochtans anders: door genoemde merkwaardigheden valt de godenschildering in dit verhaal uit den toon. Doch dit geval is een bijzonder geval, uitgewerkt onder een dwang, dien de dichter zichzelf oplegt, doordat hij van hetzelfde verhaal twee versies geeft, die stilistisch van elkaar verschillen, waarbij uiteraard de meer epische schildering aan de epische Metamorphosen ten deel valt. Wij zullen iets dergelijks nog eenige malen ontmoeten, en anderzijds ook gelegenheid hebben op "elegische" styliseering te wijzen in de godenschildering, waar wij wegens het bij uitstek episch gegeven "epische" styleering mochten verwachten (zie „Aeneae apotheosis”, „Sabini repulsi”, „Romuli apotheosis”, "Aesculapius", „Caesaris apotheosis").

Doch ook in dit verhaal behoeven $\mathrm{He}$ in ze's opmerkingen over de godenschildering een aanvulling en een retouche, een retouche, die een niet onbelangrijke modificatie beteekent. Hierover zal in het volgende gehandeld worden. Tevens zullen in het volgende naar aanleiding van zekere details enkele opmerkingen gemaakt worden, die elders moeilijk een plaats vinden.

Wat betreft Ovidius' verhouding tot zijn bronnen : over de bronnen zijn de geleerden het niet eens, hetgeen niet te verwonderen is, als men opereert met indirecte gegevens uit indirecte gegevens. Nadat $\mathrm{Ma}$ a t e $\mathrm{n}$ als Ovidius' voorbeeld 
in het algemeen van een alexandrijnsch gedicht gesproken had, pleitte B a r w i ck voor Nicander als zegsman; Herter (Pers.) evenwel neemt voor de epische Metamorphosen een epische versie van Callimachus. Wij zullen ons in het volgende niet verdiepen in Ovidius' verhouding tot zijn zegslieden, daar zij hier voor ons niet van belang is; immers volgde hij één bron, dat is het zonder meer duidelijk, dat hij tenminste in een zijner beide versies zelfstandig opereerde; volgde hij twee bronnen, dan was hij in groote lijnen aan zijn twee verschillend geaarde bronnen gebonden in zijn twee verschillend geaarde versies. Bovendien kunnen wij de details zijner voorgangers niet achterhalen, terwijl het voor een juiste waardeering en interpretatie juist op de details aankomt. Wij kunnen in het algemeen zeggen, en dit is reeds een waardevol resultaat, dat Ovidius zich van een onderscheid tusschen een meer epische en een meer elegische styliseering ook in zake der godenschildering bewust was, dat hij in vertrouwen op zijn kracht durfde te experimenteeren en vergelijkingen uitlokken, dat hij tot een meer epische styliseering, in casu een meer majesteitelijke schildering der goden in staat was.

De koning der onderwereld is beducht, dat door het woelen van Typhoeus de aarde zal scheuren en dat hierdoor het zonnelicht in zijn rijk zal binnendringen, paniek zaaiend onder de schimmen. Welk een panische schrik hem bij deze gedachte overvalt, had Homerus zeer levendig beschreven; Ovidius had van dit motief in "Phaethon" reeds gebruik gemaakt. Ook thans is Pluto's bezorgdheid groot, en wel in herinnering aan Homerus' vermakelijk motief vermeldt Ovidius in epische ongehaastheid tweemaal zijn bezorgdheid, tweemaal zijn geruststellende bevindingen, zoodat wij den god eerst scrupuleus zien speuren en dan een zucht van verlichting hooren slaken: hanc metuens cladem (359), ambibat Siculae cautus fundamina terrae; Postquam exploratum satis est loca nulla labare Depositique metus (361 vv.). Aldus speelt de dichter discreet toe op Pluto's grooten angst. Tevens verklaart hij hiermede zijn lang verwijlen boven aarde, waardoor hij de opmerkzaamheid van Venus tot zich trekt, zoodat hij, op het moment, dat hij niets meer denkt te hoeven duchten, het slachtoffer wordt van Amor.

Pluto wordt als de machtige roover voorgesteld. Zijn span kenmerkt hem. Hij ment zwarte paarden (360); elders worden de teugels roestzwart genoemd (404). Het zijn slechts enkele details, doch genoeg om ons het beeld van Pluto's span te laten aanvullen : aan het span van den duisteren god is alles duister. In de Homerische Demeterhymne evenwel (19.375.431) heeft Pluto een gouden wagen. De gouden wagen bij Homerus, de zwarte wagen bij Ovidius zijn kenmerkend voor de opvattingen van beide dichters. Bij Homerus valt de nadruk op de goddelijkheid van den bezitter, bij Ovidius op de plaats en den aard zijner werkzaamheden. Bij Homerus is Pluto's wagen evenzeer van goud als die van welken anderen god ook, omdat goud passend is bij de goden. In de oogen van Ovidius is het een dwaasheid, den duisteren god der duistere onderwereld een goudglanzenden wagen te geven, waarin de duistere Dood niet sprekend en plastisch tot uitdrukking komt. Wij hebben hier dus te doen met een herijking van mythologische gegevens, zelfstandig toegepast, waarbij het personifieerend 
moment den doorslag geeft. Bij den duisteren god van het Doodenrijk past in Ovidius' gedachtengang enkel een zwarte wagen, door zwarte paarden getrokken, zooals bij den lichtenden zonnegod een schitterglanzende wagen past, door vuursnuivende paarden getrokken, - zooals bij den god van den bloedigen oorlog een bloedbedropen wagen (Sol : $2.107 \mathrm{vv}$; Mars : 14. 819).

In dit verband moge ik herinneren aan een hypothese van $\mathrm{O}$ w e n (p. $66 \mathrm{v}$.), volgens wien het fragment currus crystallo lucidus albo, dat van Ovidius overgeleverd wordt, betrekking zou hebben op den wagen van Neptunus, afkomstig uit de verloren Gigantomachia. Crystalli, naar antieke opvatting uit bevroren water ontstaan, zouden een toepasselijke ornamentatie zijn voor den wagen van den zeegod. Ow en verwijst naar den wagen van Venus, de Schuimgeborene, bij Apollinaris Sidonius : waarvan het juk ook van crystal is (c. 11.94). Dat het geciteerde fragment uit de Gigantomachia stamt, is allerminst zeker. Ook andere dichtwerken komen in aanmerking. Waarom zou het niet even goed uit een epithalamium kunnen stammen, als het uit Ovidius stamt? Ovidius zelf spreekt (Ex Pont. 1. 2.133) van een door hem geschreven epithalamium voor Paulus Fabius Maximus, en het zou niet vreemd zijn, wanneer Statius' epithalamia, die meer mythologische fantasie zijn dan lyriek, met hun Venus-fantasieën op Ovidiaansch model teruggingen; want het is moeilijk zich voor te stellen, dat Ovidius zich, ook in een epithalamium, niet in geestrijke mythologische fantasieën ,vermeid heeft. En dan is er naast een Venus op haar zwanenspan (10.708, 717 v.), naast een Venus op haar duivenspan (14.597; vgl. Am. 1. 2. 23), nog wel plaats voor een Aphrogeneia (zie 4.536 vv.) op toepasselijken wagen. Overigens wil ik niet beweren, dat genoemd fragment inderdaad uit een epithalamium van Ovidius stamt of dat het epithalamium voor Maximus een fantasieschildering over Venus en de Amores bevatte, doch enkel aantoonen, dat $\mathrm{O}$ w e n's toewijzing van dit fragment aan de Gigantomachia op losse schroeven staat (nog afgezien van de kwestie, of Ovidius werkelijk een Gigantomachie gedicht heeft). Op de smalle basis van zulk een los fragment is nauwelijks iets positiefs te zeggen. De wagen is blijkbaar niet van aardsche constructie, en houdt, misschien, verband met een godheid der zee, of een godheid, die met de zee verband houdt. Misschien werden nadere details over dezen wagen gegeven, misschien moest dit detail aan de fantasie des lezers een aanduiding zijn, hoe dezen verder zich voor te stellen. Meer kunnen wij over dit fragment niet zeggen. Wel kunnen wij in het algemeen zeggen, dat, als Ovidius Neptunus' wagen zou beschrijven, hij in de materialen ervan (en in den vorm misschien) stellig 's goden heerschappij over de golven tot uitdrukking zou brengen, af wijkend van de Homerische schildering (XIII $23 \mathrm{vv}$.), die met het goddelijk goud opereert.

Venus wekt Amor op om Pluto een pijl in het hart te schieten. Deze scene herinnert aan een soortgelijke episode in Aeneis I en in Apollonius Rhodius' derde boek. Daar deze drie scenes elk karakteristiek zijn voor elk der dichters en er verband tusschen bestaat, zullen wij ze achtereenvolgens bespreken.

Apollonius. Men heeft zich afgevraagd, of niet bij Callimachus in het beroemde verhaal van Acontius Aphrodite door toezegging van vijf bikkels Eros overhaalde om Acontius met een liefdespijl te treffen (D i e $z$ zl e r p. 10). Indien 
dit het geval is geweest en indien de Aetia eerder zijn gedicht dan de Argonautica, heeft Apollonius in zijn schildering Callimachus nagevolgd, het thema op epische wijze styliseerend. Bij hem komt de groote Aphrodite formeel als smeekelinge tot haar kleine, verwende, eigenzinnige ventje, welks uiterlijk zulk een merkwaardig contrast oplevert met zijn macht. Het is de geduchtste der goden, al omklemt het met beide armen moeders rokken, al trekt de moeder het tot zich om het te kussen, al wordt het gepaaid met een prachtig stuk speelgoed, al bikkelt het en telt het zijn bikkels goed na. Om zijn medewerking te verkrijgen, vat Aphrodite hem bij de kin (de geste der smeekelingen), de moeder haar kind, de volwassene het jongetje ; de omgekeerde wereld. Daar is berekening in dit contrast. Misschien is het opgevat door den dichter als complement en het tegenovergestelde van wat Callimachus in zijn Artemishymne schildert: daar, na haar verlanglijstje opgezegd te hebben, strekt de dreumes Artemis, knusjes op vader's knie zittend, haar armpjes uit om de kin van den grooten god te vatten, vergeefs (4.26). Callimachus zoekt hier het contrast met de groote Homerische scene, waarin Thetis als smeekelinge komt tot den machtigen donderaar (I 500 vv.; Herter 56 en 68 vv.). In den geest van Callimachus zoekt $z 00$ Apollonius in de overeenkomsten het contrast met de oude epiek. Hetzelfde treft ons verderop : nadat hij gewonnen is, gaat Eros, het ventje, zich wapenen, hetgeen door Apollonius even omstandig beschreven wordt als Homerus een krijger beschrijft, die de wapenen aanlegt. Wanneer hij zijn plaats van bestemming bereikt heeft, wordt uitvoerig beschreven, hoe hij positie kiest, zijn boog spant, een pijl neemt, mikt en schiet ( 278 vv.), en terecht, want dit is het beslissende moment van het epos (waarin een jongetje de machtigste is); men voelt zich echter herinnerd aan Homerus' beroemde schildering van de voorbereidingen tot en het schot zelf van Pandarus in Ilias IV, dat voor het verloop van den oorlog van het uiterste gewicht is. In de schildering van Eros door Apollonius is er dus een contrast tusschen het nietig uiterlijk en den kinderlijken geest van den god en zijn groote macht, en wel tegen den achtergrond van groote Homerische scenes. Het is een bewuste, op contrast berekende bagatelliseering der goden.

Vergilius. Het idee van de scene tusschen Venus en Amor heeft Vergilius aan Apollonius ontleend. Doch verre van de bagatelliseering te continueeren, is de Romein erop bedacht deze op te heffen. De uiterlijke details worden zooveel mogelijk beperkt. Van Amor wordt enkel gezegd, dat hij aliger is (663), en zelfs dit epitheton zou wellicht achterwege gebleven zijn, als niet later de vleugels van den god ter sprake zouden komen; het afleggen der vleugels is het eenige detail, dat aan onze fantasie gegeven wordt, als Amor de gedaante gaat aannemen van Ascanius. Amor schiet ook geen pijl af op Dido. Met het schot van Amor was door de alexandrijnsche dichters te zeer gesold dan dat het in een ernstig, hoogstrevend gedicht nog met succes gebruikt kon worden. Dat Dido in den omgang met den vermeenden Ascanius langzamerhand een volslagen ommekeer van gevoel ondergaat, past daarentegen voortreffelijk in Vergilius' gevoelswereld en delicate kunst. Ook omhelst Venus haar zoon niet, zij spreekt hem toe (adfatur, 663), en al noemt zij zich, wegens haar toestand en om zijn 
hart te roeren, supplex (666), aan zijn voeten werpt zij zich niet noch paait hem met speelgoed. Roept zij Amor's hulp in, het geschiedt enkel, omdat de liefde haar eenige machtsmiddel is om aan Aeneas de dringend gewenschte veiligheid te geven : nate, meae vires, mea magna potentia, solus (664). En Amor is niet een verwend, egoistisch ventje; hij heeft oog en hart voor de zorgen zijner cara genetrix (689); hij denkt in grooten stijl voor een groote zaak, en gehoorzaamt dan ook terstond. Hij leeft intens mede met zijn moeder (669) en met de lotgevallen en bestemming van Aeneas, zijn broeder, want Vergilius schroomt niet om zoover te gaan, dat Venus spreekt van frater ut Aeneas pelago tuus omnia circum etc. (667) : een wel zeer ongelukkig motief ; want al is voor den Vergiliaanschen Amor deze bloedverwantschap een reden te meer om zijn moeder ter wille te zijn, het feit blijft, dat deze genealogische aanduiding bij den lezer, na alles wat over Amor en de liefdes van Venus gedicht is, beuzelige en hier penibele gedachten oproept. Wij zien dan ook, dat de elegiaci dit ongelukkig motief van Vergilius gretig aangrijpen. Bij Tibullus spreekt de Sibylle Aeneas aan met: Impiger Aeneas, volitantis frater Amoris, Troica qui profugis sacra vehis ratibus $(2.5 .39$ v.). Met een zijdelingschen blik naar de Aeneis weet Ovidius in zijn threnodie op Tibullus te berichten: Fratris in Aeneae sic illum (sc. Amorem) funere dicunt Egressum tectis, pulcher Iule, tuis (Am. 3.9.13 v.); en bij denzelfden dichter roept Dido uit : parce, Venus, nurui, durumque amplectere fratrem, Frater Amor (Her. 7.31 vv. ; cf. 157). Het broeder-motief is dus wel het ongelukkigste motief dezer ongelukkige scene; want Venus en Amor blijven na zooveel alexandrijnsche poëzie steeds in den geest des lezers iets alexandrijnsch behouden. Doch slechts hij, die zich van Vergilius' groote durf en zelfstandig. heid bewust is, beseft de tragische mislukking dezer scene ten volle.

Ovidius. Ovidius' scene heeft, tenminste gedeeltelijk, de scene uit de Aeneis tot achtergrond.

Vergilius : ergo his aligerum dictis adfatur Amorem: 663

'nate, meae vires, mea magna potentia, solus,

nate, patris summi qui tela $T$ yphoea temnis, etc.

Ovidius: natumque amplexa volucrem, 364

'arma manusque meae, mea, nate, potentia,' dixit,

'illa, quibus omnes superas, cape tela, Cupido etc.

De overeenkomst tusschen beide dichters blijft echter, zelfs in de geciteerde verzen, beperkt tot een oppervlakkige gelijkheid van woorden en motief. Niet meer wordt Amor als haar eenige macht aangeduid (solus is bij Vergilius van bijzonder gewicht en staat daarom emphatisch aan het verseinde), hij is niet meer haar vires, doch wordt, de kleine schutter, puntig haar arma manusque genoemd, waarvan de beteekenis in het volgende duidelijk zal worden. Bij Ovidius is ook weer van omhelzing sprake; Apollonius volgt hij hierin evenwel niet na ; want er is geen sprake van een smeekelingengeste, doch slechts van een koozend omhelzen, zooals dit bekend was uit de schilderkunst, waarheen de dichter ook elders verwijst (namque pharetratus dum dat puer oscula mater, 10.525). Ook heeft Amor zijn wapenen bij de hand, hetgeen bij Apollonius niet het geval 
was, doch wat wel is overeenkomstig de schildenngen uit Ovidius' tijd (qualia namque Corpora nudorum tabula pinguntur Amorum, talis erat, sed, ne faczat discrimina cultus, Aut huic adde leves aut illi deme pharetras, $10.515 \mathrm{vv}$ ) Ook un het spannen van den boog schildert Ovidius naar werken der beeldende kunsten (oppositoque genu curvavit flexale cornum 383 ; vergelijk questus eram, pharetra cum protinus ille soluta Legit in exitium spicula facta meum Lunavitque genu sinuosum fortiter arcum, Am. 1. 1.21 vv. + B randt, en viderat adducto flectentem cornua nervo, 1.455), zoodat Ovdius voor het uiterlijk van Amor herinnert aan de plastiek, waann deze als het typische alexandrijnsche ventje geteekend wordt In de motiveering van het schot gaat Ovidius geheel eigen wegen. Als bij Vergilius behoeft Amor niet omgekocht te worden; ook bij Ovidius behoeft hy enkel opgewekt te worden, heeft hy imperiaal gevoel. Doch welk een impenum' Door de bedwinging van Pluto zal het imperium van Venus en Amor gevestigd worden over hemel, aarde en onderwereld De hemel, Juppiter aan het hoofd, de zee, Neptunus aan het hoofd, zijn reeds bedwongen : cur non matrisque turimque Imperium profers? agitur pars tertıa mundı (371 v). Op dit impenum is de befaamde term dyarchie waarlık van toepassing : pro socio regno (378). Venus wikt en weegt, Amor is de uitvoerende macht, - zoo men wil, de sterke arm : daarom heet hy arma manusque. Er wordt dus aan groote politiek gedaan. Als verziend politica ontpopt zich Venus ook in haar tweede argument. In den hemel zijn Pallas en Diana, de maagden, onafhankelijk gebleven; nu dreigt Proserpina denzelfden weg op te gaan; ook zil heeft onafhankelyke neigingen : nam spes adfectat easdem (377). Deze beweging, die gevaarlijk kan worden, dient in de kiem gesmoord (Pallas en Diana werden in deze mythe met Prosperina verbonden genoemd, $\mathrm{Ehw}$ ald ad 375 ; Ovidius heeft dit aangegrepen om er een tweede motief uit te brouwen voor zijn imperiale fantasie). Het eene schot heeft dus een dubbele uitwerking en vestigt de heerschappij van Venus en Amor definitief. Nu is, zooals wij zagen, het motief van de heerschappij der liefdesgoden over goden en menschen alexandrunsch; reeds in „Daphne" had Ovidius er gebruik van gemaakt; hier geeft hij er een nieuwen, eigen, Romeinsch-impenalen vorm aan. Deze scene dus als motiveering van Pluto's roof is weliswaar episch, doch niettemin alexandnjnsch in wezen en alexandrijnsch in zijn speelsche, eigentijdsche utwerking.

Aan Proserpina is niets goddelijk tenzij haar naam. De dichter teekent haar als een pretentieloos, argeloos meisje, nog een kind. $Z_{1 j}$ plukt bloemen puellari studio (393), trachtend haar vriendinnetjes te overtreffen. Geroofd, roept zij om haar moeder en speelnootjes, doch om moeder vooral. Vertwiffeld nut zij haar kleed open, de bloemen vallen weg, tantaque simplicitas puerilibus adfuit annis. Haec quoque virgineum movit ractura dolorem (400 v.). Simplex wordt zij ook nog in het vervolg van het verhaal genoemd (535). Zooals ut de aanhalingen blykt, schildert de dichter haar niet enkel in feite, doch wil hij haar ook als een gewoon menschenkind. $Z_{11}$ vormt een dankbaar contrast met den vervaarlyken roover.

Dat Ceres in de beschrijung van haar wraakgencht aan de aarde als een machtige energieke godin geteekend wordt, is reeds opgemerkt. $Z_{y}$ breekt de 
ploegen, slaat boeren en ploegvee met den dood en beveelt de akkers slechts misgewas voort te brengen. De twee eerste opmerkingen geven haar onmiddellijk wraak, het laatste wordt door den dichter met ongunstige atmospherische omstandigheden en anderszins verklaard, waarin dus Ceres' wraak slechts indirect aan het licht treedt.

Ceres vaart op haar wagen ten hemel, op haar wagen, teeken harer waardig. heid als frugum genetrix. In vv. 642/3 wordt deze wagen, de slangenwagen, uitvoeriger geteekend; ook 8.794 v., evenals Fasti 4.497 en 561, wordt hij vermeld. Wat de bijzondere wagens der goden betreft, getrokken door andere dieren dan paarden, deze hebben Ovidius' warme belangstelling. Hij noemt van Venus den duivenwagen (14.597, ofschoon het onderwerp niets minder is dan de apotheose van Aeneas; vgl. Am. 1.2.23) en den zwanenwagen (10. 717 v.), van Juno den pauwenwagen (2.531 v.), van Cybele den leeuwenwagen (14. 538) en van Bacchus den tijgerwagen (4.24). Wat hem in deze attributen aantrekt, is het ongewone en schilderachtige, het fantastische en het artistiek effect.

Proserpina heeft haar vasten verbroken. Hoe geschiedde dit? In de Homerische Demeterhymne door een sluwe manoeuvre van Hades (317 v.). Ovidius wijt het aan de simplicitas van Proserpina zelf: cultis dum simplex errat in hortis, puniceum curva decerpserat arbore pomum (535 v.). Denkt men de onderwereld weg, dan ziet men een tafereeltje uit de Campagna, uit een der talrijke culti horti, die zich daar uitstrekten. Romeinsche tuinen in de onderwereld! deze ontbraken nog maar aan de moderne schildering van Doodenstad in "Ino". Vermenschelijking en moderniseering dus.

\section{ARETHUSA (V 572-641)}

Het verhaal van Arethusa en Alpheus is bekend; Ehwald (ad 572 vv.) wijst op het alexandrijnsch karakter van vele motieven. Er ligt een zonnige glans over de vertelling. In de voorgeschiedenis der achtervolging vinden wij dezelfde berekende retardatie, die aan de badscenes in "Callisto" en "Actaeon" een bijzondere ironische bekoring geven. Levensecht wordt geteekend, hoe Arethusa er toe komt een bad te nemen en in het water dartelt. De grootste bekoring gaat echter uit van de omstandigheid, dat de nymph zelf vertelt, en dat op haar charmante wijze. De luchtige wijze van vertellen past wonderwel bij het luchtig avontuur. Men zie bijv. : sicut eram fugio sine vestibus : altera vestes Ripa meas habuit (601 v.); - sol erat a tergo : vidi praecedere longam Ante pedes umbram, nisi si timor illa videbat; Sed certe sonitusque pedum terrebat (614 vv.); - et citius, quam nunc tibi facta renarro, In latices mutor (635 v.). Alleen al de wijze, waarop de hoofdpersoon vertelt, beteekent hier, zoowel als in andere verhalen, als „Echinades”, „Achelous et Hercules”, „Glaucus”, vermenschelijking. In "Arethusa" komt daar nog bij, dat zij verlicht is, de keuvelgrage. Als jageres, hoort zij eigenlijk tot het type der preutsche volgelingen van Artemis. Doch over haar preutschheid is zij nu heen : 
nec mea me facies nimium laudata iuvabat, 582

quaque aliae gaudere solent, ego rustica dote

corporis erubui crimenque placere putavi.

Zij spreekt openlijk uit, wat de dichter van Daphne suggereerde :

illa velut crimen taedas exosa iugales 1.483

pulchra verecundo suffunditur ora rubore.

Velut crimen: het is echter geen crimen; wie zoo denkt, is rusticus. Ehwald interpreteert dit woord te onschuldig als "voll ländlichen Einfalt". Rusticus is het ergste verwijt, dat een rechtgeaard Augusteër kon worden gedaan; Ovidius heeft er in zijn erotische werken den mond vol van (B r a ndt ad Ars 2. 566). Ook dos corporis herinnert aan Ovidius' erotische werken. Wij hooren weliswaar ook in de Metamorphosen van dotatissima forma (11.301) en laudatissima formae Dote (9.716 v.), doch deze uitdrukkingen gaan terug op de dotes puellae uit de elegie (Am. 2. 4. 38 ; Rem. Am. 325, vgl. 331), waaronder de dotes formae (Her. 15.307 v.) een voorname plaats innemen : est illis sua dos, forma sine arte potens (Ars 3. 258). Wij hebben dus met een moderne, verlichte nymph te doen. Dat blijkt ook wel uit de kostelijke commentaren, die zij geeft op haar penibele situatie : et, quia nuda fui, sum visa paratior illi (603) of : vertitur in proprias,

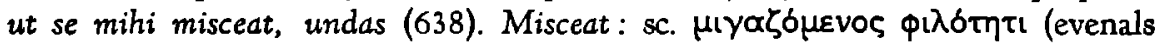
13. 866 ; vgl. Apul. Met. 9.24 : cum eodem illo iuvene miscebatur in venerem). Achter dezen schijn van onschuld en openhartigheid gaat de berekendste pikanterie schuil. Dit heeft Malten (p. 515) zuiver gevoeld: „In pikanten Wendungen erzählt die Nymphe von ihrer Nudität". Ribbeck (p. 300) echter, volgens wien zij spreekt "mit weiblicher Anmut und Unschuld", is het slachtoffer harer verkapte ars: si latet ars, prodest (Ars 2.313 ; vgl. ars faciem dissimulata iuvat, Ars 3.210); ars casu similis (Ars 3.155). Arethusa is door Ovidius dus gemoderniseerd in haar opvattingen en conversatie naar de meisjes uit de wereld der elegie.

De figuur van Alpheus blijft meer op den achtergrond. Zijn uiterlijk wordt niet beschreven. Wel vinden wij enkele details, die het spel met de dupliciteit van zijn wezen verraden. Rivier en god zijn één: Alpheus heeft de gestalte van een man aangenomen, doch als de begeerde in een bron verandert, verandert hij zich weer in proprias undas (638) : proprias, want hij bestaat eigenlijk uit water, zooals $\mathrm{Ehwald}$ het woord terecht verklaart. Men vergelijke Achelous in „Echinades". Zooals Ovidius elders met de dupliciteit van bepaalde goden speelt in het woord "zich" (Tellus trekt zich in zichzelf terug etc.), zoo speelt hij er hier mede door proprius. Over de erotische beteekenis van se miscere is reeds gesproken; in deze passage spelen beide beteekenissen, de letterlijke en de figuurlijke, dooreen. Het persoonlijke en het zakelijke moment zijn verder verweven in rauco ore (600); ook elders spreekt Ovidius over de rauca ora van riviergoden (Am. 3.6.52: Anio; Fast. 5.638: Thybris).

„Arethusa" wordt dus gekenmerkt door vermenschelijking en moderniseering, door het spel met de dupliciteit van den riviergod en bovenal door een charmante ironie en pikanterie. De opbouw der Metamorphosen bracht mede, dat Arethusa 
zelf haar avontuur zou vertellen, zooals dat ook met vele andere verhalen het geval is; Ovidius heeft echter van de mogelijkheden, die hierdoor geboden worden, even dankbaar als kundig gebruik gemaakt.

\section{ARACHNE (VI 1-145)}

In dit verhaal vragen vooral drie dingen onze aandacht: Arachne's motieven, de waardeering van haar prestatie, en de animositeit van Pallas.

In tegenstelling tot Pallas, die de goden in klassieke majesteit uitbeeldt (augusta gravitate, 73), geeft Arachne een reeks liefdesavonturen der goden, waarin hun goddelijke majesteit onder al de vermommingen verre te zoeken is; zij geeft caelestia crimina (131), 21 gevallen, waarin vrouwen het slachtoffer zijn van vermomde goden, van Juppiter 9, van Neptunus 6, van Apollo 4, van Bacchus en Saturnus elk 1. Dat Ovidius hierbij uit een rijken cataloog van goden. liefdes heeft geput, bewijzen, zooals $\mathrm{Ehwald}$ (ad 103) opmerkt, de talrijke overeenkomsten met passages uit Hyginus en de Christelijke apologeten. Het beslissende is echter, leerzaam tevens, hoe Ovidius dit materiaal verwerkt heeft.

Juppiter is het sterkst vertegenwoordigd, iets wat men den oppergod verschuldigd was, die op een ongemeen vruchtbaar liefdesleven mocht bogen. Op hem volgt Neptunus, Neptunus fratri par in amore Iovi (Prop. 2. 26. 46). Hierna wordt de oposmming onderbroken door de opmerking omnibus his faciemque suam faciemque locorum Reddidit (121 v.). Ik geloof niet, dat Ovidius hiermede iets omtrent de compositie van het doek wil zeggen of de uitwerking van de nog volgende gevallen; de tusschenopmerking heeft wel tot doel, de genoemde goden, als de grootste belhamels, van de overige hemelingen te scheiden; een hierarchisch doel dus. Apollo daarop, in den minnehandel vermaard, bezet met 4 gevallen een eervolle derde plaats; terwijl de twee laatste goden de representanten zijn der overige gelukzaligen, die allen in Liefde's Schouwtooneel hun rol spelen. Doordat Neptunus geapostropheerd wordt, is er tusschen zijn groep en die van Juppiter een duidelijke demarcatielijn. Ondat één Juppiter, ook in puncto Veneris, tegen alle andere goden opweegt, beslaat de beschrijving zijner escapades evenveel verzen als die van de avonturen der overige Olympiërs, Neptunus incluis. Het is wel reeds duidelijk, dat ons hier niet de compositie van Arachne's kunstwerk gegeven wordt, als wel een specimen van een litterairen cataloog, op geraffineerde wijze opgebouwd.

Ook de opsomming in de afzonderlijke groepen is zeer kunstig. Groep Juppiter opent met een beschrijving der ontvoerde Europa, het bekendste van Juppiter's vrouwelijke slachtoffers (talis eras: aquilamque in te taurumque tinebam, Et quidquid magno de Iove fecit amor, Am. 1.10 .7 v.), in de beeldende kunsten zeer geliefd, waarin zij de typische houding gekregen had, welke Ovidius ook hier beschrijft (zie $\mathrm{Eh}$ wald ad 2.874). Zinrijk opent dus de dichter de reeks met een betrekkelijk uitvoerige schets van het meest bekende en meest schilderachtige geval; naar bestaande kunstwerken schildert hij een fictief kunstwerk. De volgende groep van vier, die $1+1+2+1$ verzen beslaat, wekt door den registreerenden toon der anaphoor (fecit-fecit-addidit) den indruk, dat de dichter 
uit overvloedig materiaal een willekeurigen greep doet. Versterkt wordt deze indruk nog door de laatste groep van vier, die $1 / 2+1 / 2+1 / 2+1 / 2$ verzen beslaat, welke door haar onopgesmukte nuchterheid een eindelooze reeks suggereert.

In de volgende groep Neptunus brengt de dichter, behalve door de reeds genoemde apostrophe, variatie door de omschrijving der slachtoffers, en door een kunstig emjambement. Er zijn twee correspondeerende groepen van drie, die elk $11 / 2+1+1 / 2$ verzen beslaat; van het derde slachtoffer wordt de patrony. micum gegeven, van het zesde de eigennaam.

De derde groep, die der overige goden, wordt weer gekenmerkt door den onopgesmukten cataloogstijl, en beslaat $1+1 / 2+1 / 2+1$ (Apollo) en $1+1$ verzen (Bacchus en Saturnus). Daarnaast kan men de indeeling $1 / 2+1 / 2+1 / 2+1+1+1$ verzen maken : in de eerste drie gevallen worden geen namen, in de laatste drie wel namen genoemd.

De cataloog van Arachne's onderwerpen is dus zeer kunstig en zeer zinrijk. Het geeft de erotische prestaties en rangorde der goden treffend weer. Het geheel laat niet na, den indruk te wekken van eindelooze escapades, en is een bijzonder hoonend requisitoir tegen de wulpsche goden. Hun amours culmineeren in het weefsel van Arachne; na de vele verhalen, hieraan gewijd in de voorafgaande vijf boeken, is dit, zooals R and (p. 63) opmerkt, "the grand finale of Ovids Divine Comedy. Arachne is promptly turned into a spider; what condign metamorphosis should be decreed to the poet, Diana might decide. He deserves a prize for ridiculing an outworn theology with a fine pungency beside which Lucian's diatribes seem primitive and tame".

Opmerkelijk is de waardeering van het kunstwerk. De dichter verklaart emphatisch (non-non), dat noch Pallas noch Livor het konden beknibbelen; het is een volledig succes:

\section{non illud Pallas, non illud carpere Livor 129 possit opus: doluit successu flava virago etc.}

$\mathrm{Nu}$ is, als wij het wel hebben, in dergelijke verhalen van wedstrijd tusschen sterveling en godheid, het succes van den aardworm hoogst ongewoon : de menschelijke prestatie dient volkomen inferieur te zijn aan de goddelijke. Marsyas, uitdager van Apollo, ondergaat na zijn nederlaag zijn welverdiende straf (6.384); in den strijd tusschen Muzen en Pieriden verklaart de jury de laatsten eenparig voor verslagen (5.663); zelfs het gepijp van god Pan, die Apollo naar de kroon streeft, is een barbaarsch en hartverscheurend gesnerp naast Apollo's waarlijk goddelijke kunst (11.161 vv.). Doch in "Arachne" is niet de stervelinge overwonnen, is Pallas, de godin, om het voorzichtig te formuleeren, niet onbetwistbaar de meerdere. Ovidius zegt weliswaar niets ten ongunste van Pallas' prestatie, maar hij zegt wel veel gunstigs van Arachne's prestatie. Dit is aan verschillende litteratuurcritici ontgaan. Het is onjuist, dat, naar een opmerking van $E h$ w ald (ad 103), Ovidius Arachne, in tegenstelling tot Pallas' fraai gecomponeerd doek, een onoverzichtelijk agglomeraat laat maken, aldus de goddelijke klaarheid stellend tegenover menschelijke buitensporigheid; dat, naar de meening van B a rtholomé (p. 79), Pallas "ook" in compositiekunst moet winnen. Ovidius 
kon niet duidelijker zeggen, dat Arachne's werkstuk uitnemend was. Vanwaar deze innovatie in deze waardeering van de prestatie der stervelinge? Ik geloof, dat de dichter der bonte Metamorphosen met haar caelestia crimina aan deze voorgangster in motieven en compositie zijn bijzondere sympathie wilde betuigen en in haar het collectieve gedicht wilde eeren. In deze richting wijst het vermelden van Livor, Livor, die ook Ovidius, in de werken zijner eerste periode zeker (zie bijv. Am. 1.15 en Rem. Am. 389 vv.), doch waarschijnlijk ook in zijn hoofdwerk, niet onaangetast liet. Vertegenwoordigt Pallas' doek de oude, klassieke kunst der augusta gravitas, en dat van Arachne de moderne richting, verkleint Ovidius de kunst der oude richting niet, maar vernedert hij de nieuwe richting ook niet, dan is het geloofwaardig, dat Ovidius in het verhaal van Arachne twee stijlen naast elkaar stelt, het verschil tusschen beiden constateert, beiden in hun goede vertegenwoordigers uitmuntend vindt, klassieken en modernen gelijkwaardig noemt. Hij geeft ook v. $7 / 8$ hoog op van Arachne's ars. Laudamus veteres, sed nostris utimur annis: Mos tamen est deque dignus uterque coli (F. 1.225/6).

Tenslotte wijzen wij op de animositeit van Pallas. Arachne geeft daartoe ongetwijfeld aanleiding, door haar trots, door haar verstoktheid tegen alle vermaan in, en niet in de laatste plaats door het onderwerp, dat zij behandelt, het hoonende. Om haar houding dan ook, niet om haar prestatie, verdient zij getuchtigd te worden. Dat neemt niet weg, dat men van de godin meer waardigheid mocht verwachten dan zij nu ten toon spreidt, als er al van waardigheid sprake kan zijn. $Z_{i j}$ handelt niet erg lady-like. Geprikkeld, onbeheerscht, scheurt zij het hoonend weefsel uiteen; dit is vergeeflijk; doch dat zij haar mededingster met den weefspoel te lijf gaat, dien zij in haar hand heeft, is al te menschelijk. Dit verwacht men niet van de godin, die door de nymphen en de Lydische vrouwen vereerd en gehuldigd wordt, als zij haar goddelijkheid openbaart (44 v.). Het is overigens de uitbarsting der animositeit, die zij reeds tijdens het weven verraadt. Daarin gaat zij geheel op, evenals haar rivale : bedrijvig, de kleeren opgeschort, studio fallente laborem (60); B oissier (P.A. p. 376) vermeldt deze details, als hij spreekt over de vermenschelijking der goden. Voor Pallas" animositeit zie ook onder "Herse".

Wij geven tot slot een citaat uit een boek van een niet vakman, dat ons toevallig in handen kwam; de schrijver, een fijnzinnig artiest, geeft, door geen geleerde theorieën misleid, de quintessens van Ovidius' verhaal beter weer dan $\mathrm{E} h \mathrm{~h}$ w ald of Bartholomé. Peinzend over de spinnen, schrijft hij: "Poor Arachne, who gave her name to the whole race of spiders, Arachnida. It was no doubt a little presumptuous on her part to challenge a goddess to a weaving contest, but she certainly seems to have been a well-educated and broad minded girl, if we are to believe Ovid's description of her finished work. Not a thread can have been idle in that vivid fabric. Not only did she faithfully portray Jupiter as a bull carrying away Europa, as a swan prevailing over Leda, as a golden shower embracing Danaë, in addition to many of the god's minor conquests, but she also included a representative selection of somewhat similar character from the life histories of Neptune, Bacchus, and Saturn. It must have been a rich canvas. 
Against this, Athena had merely depicted, 'the hill of Mars with twelve heavenly gods on lofty thrones in awful majesty, and it is easy to suppose that subject-matter may have influenced aesthetic judgment when the prize was awarded to Arachne. Even so, the goddess should have accepted defeat with better manners. In my opinion it was sheer ill-breeding on her part to set about poor Arachne with a hard-wood shuttle. And, when the poor girl in desperation hanged herself, it was a venomous piece of work to turn her into a spider and compel her to live on for ever as one of those skulking creatures who get no respect or affection from man or beast, and live only to spread their treacherous spirals about the countryside.

My sympathies were all with Arachne as I wandered down-stream." (R o bert Gibbing s, "Sweet Thames Run Softly", p. 14/5 van de Guild Books Edition (No. S 100), London 1944.)

\section{NIOBE (VI 146-312)}

In dit verhaal is voor ons van belang de schildering van Latona. Doch eerst willen wij eenige aandacht schenken aan de teekening van de tegenspeelster der godin, Niobe. Op last van de zieneres Manto brengen de Thebaansche vrouwen aan Latona en haar kinderen goddelijke eer; Niobe echter, zich hiertegen verzettend, richt uiterst smalende woorden aan het adres der godin en eischt voor zichzelf goddelijke eer op. Zooals Ehwald (ad 146) opmerkt, zijn zoowel Manto's gebod als Niobe's eisch om goddelijke eer voor haarzelf eigen verzinsels van Ovidius; de bedoeling ervan is duidelijk : Niobe's schuldigen overmoed op de spits te drijven ; haar vroegere misdaad, dat zij namelijk, prat gaande op eigen kindertal, smalend afgeeft op dat van Latona en zich onaantastbaar noemt, wordt onder Ovidius' handen tot een motief voor haar excessieven eisch van goddelijke vereering. Haar optreden schreit ten hemel om wraak. De dichter is er op bedacht, haar overmoed aannemelijk te maken, en ontwerpt zoo het beeld eener alleszins indrukwekkende koningin. Haar verschijning, haar escorte, haar houding is waarlijk koninklijk verheven. Ook uit haar woorden spreekt een koninklijk dédain; zij is niet geniepig, maar gaat recht door zee; verachting spreekt uit haar woorden over Latona, op wie zij neerziet als een zielig en beklagenswaardig geval. Mateloos is haar trots, doch alle kleinheid is haar vreemd. $\mathrm{Z}_{\mathrm{ij}}$ is een vrouw van grootsche allure, waardig goddelijk genoemd te worden, als zij het niet zelf beval.

Wij mogen verwachten, dat Ovidius tegenover deze stervelinge een machtige, machtig wrekende godin in het veld brengt. Doch wij worden hierin teleurgesteld. Indien wij Niobe met Latona vergelijken, is er van de majesteit der laatste weinig te bespeuren. Treedt Niobe in het openbaar op, met indrukwekkend escorte, Latona onderhoudt zich met haar kinderen op den top van den Cynthus, op Delos, niet op den Olympus, doch als het ware in huiselijken kring, in het ouderhuis. Aan Niobe wordt een rede in den mond gelegd, aan Latona niet meer dan een klacht. Niobe is zeer energiek, hetgeen van Latona niet gezegd kan worden : deze is meer gekrenkt dan toomig, meer passief klagend 
dan actief van wraaklust vervuld, meer de zwakke moeder, die haar nood klaagt en heul zoekt bij haar sterke kinderen, dan de godin, die de wraak zoo al niet zelf ter hand neemt dan toch gebiedt en een machtswoord spreekt. De indruk, dien haar woorden wekken, is, dat, als zij niet haar kinderen had, de godslastering ongewroken zou blijven. $\mathrm{Z}_{\mathrm{ij}}$ is geshockeerd: en ego, vestra parens, vobis animosa creatis (206); an dea sim, dubitor! (208). Het verhaal vraagt, dat de stoot tot wraak uitgaat van de beleedigde; dit geschiedt bij Ovidius ook, doch hoe ! niet bij wijze van opdracht of bevel, doch bij wijze van wensch, en wel een wensch, die meer de verwensching lijkt eener getergde, dan een bede of een verzoek. En deze wensch is in een tusschenzinnetje geuit : vósque est postponere natis Aúsa suis et mé, quod in ip s a m reccid a t, órbam Dixit (211 vv.). Op dezen wensch van wraak kwam het voor de ontwikkeling van het verhaal aan. Daarom, zoodra zij hem geuit heeft, heet het : adiectura preces erat his Latona relatis: 'desine' Phoebus ait 'poenae mora longa querella est.' (214 v.). Deze coupure herinnert aan een soortgelijke coupure in "Ino"; zij prikkelt de fantasie des lezers. $\mathrm{Zij}$ typeert zoowel de voortvarendheid van den wreker Apollo als de neiging van Latona tot querellae. Er schuilt waarschijnlijk een rhetorische verwijzing in (Latona geeft een querella : eerst een referaat, relata, dan de preces), doch het leven gaat voor de rhetorische voorschriften. Het voornaamste is, dat door deze coupure het verhaal energiek wordt voortgezet en naar zijn hoogtepunt gestuwd.

Latona wordt dus door den dichter geteekend als een zwakke, klagelijke vrouw, van wie de wraak, als men het zoo mag uitdrukken, slechts formeel, als bij toeval, uitgaat. Terwijl de dichter Niobe omhoog heft, haalt hij Latona naar omlaag, zoodat Niobe bijna een godin wordt, Latona bijna een mensch. Indien wij Latona enkel uit Ovidius' verhalen kenden, zouden wij er aan mogen twijfelen, of zij inderdaad wel een godin is, om niet te spreken van de godin, die, naar zij zelf zegt (207), enkel door Juno overtroffen wordt. Tegenover de Ovidiaansche Latona heeft de verachting van Niobe eenige reden van bestaan. $\mathrm{Zij}$ is toevallig ook nog godin ; zij werd als godin geboren; dat is al het goddelijke aan haar. Het behoeft wel geen betoog, dat Ovidius niet door het verhaal gedwongen was, Latona aldus te schilderen, integendeel, zoo hier als in het volgend verhaal worden wij in onze verwachtingen eener verhevene, wrekend zich verheffende godin teleurgesteld.

Ovidius staat echter niet alleen in zijn conceptie van Latona als de weinig energieke, de godin, die achter haar kinderen schuil gaat. Op grond van allerlei mythen had reeds Callimachus haar in zijn Deloshymne, met niet gering ironisch pathos, als een jammerlijke en jammerende figuur geteekend. Ons verhaal lijkt in zekeren zin wel een vervolg op dat van Callimachus. Het is, als wilde de dichter zeggen, dat dezelfde vrouw, die als erbarmelijke verschoppelinge onder de meest ellendige omstandigheden op het uitschot der aarde haar kinderen ter wereld moest brengen, thans, nu haar kinderen volwassen zijn, slechts een zwakke, klagende moeder kan zijn. Naar de hymne van Callimachus verwijst Ovidius onmiskenbaar in Niobe's woorden, die er het essentieele in puntige bewoordingen van samenvat : 
cui maxima quondam 186

exiguam sedem pariturae terra negavit.

nec caelo nec humo nec aquis dea vestra recepta est :

exsul erat mundi, donec miserata vagantem

'hospita tu terris erras, ego' dixit 'in undis'

instabilemque locum Delos dedit.

Ovidius sluit zich hier dus aan bij den coryphee der alexandrijnsche poëzie in zijn vermenschelijking der godin. Treedt Latona in "Niobe" niet op den voorgrond, in het volgende verhaal, waarin zij de hoofdrol vervult, valt dit te meer op.

\section{LYCII COLONI (VI 317-381)}

Dit verhaal putte Ovidius uit Nicander, wiens versie wij bij Antoninus Liberalis c. 35 gerefereerd vinden.

Het verhaal gaat uit van de geboorte van Latona's tweeling op Delos. Latona vond op haar smeeken nauwelijks plaats op het dolende Delos, dat toen nog als een onbeduidend eiland in zee rondzwom. In deze details stemt Ovidius overeen met Callimachus' Deloshymne, en wij zouden geneigd zijn in het gerefereerde een verwijzing naar Callimachus te zien, zooals wij er ook een vinden in het voorafgaand verhaal, ware het niet, dat ook Nicander in zijn verhaal van Delos uitging, dat hij geleerdelijk aanduidt als Asteria, den ouden naam van Delos, door Callimachus in zijn hymne vermeld (224 vv.). Afwijkend van Callimachus, spreekt Ovidius van een palm en olijfboom op Delos (zoo ook 13.634 v. ; daarentegen slechts één boom in den brief van Cydippe, v. 100); Callimachus spreekt slechts van een palm. Deze af wijking aan invloed van Nicander toe te schrijven is bij een dichter als Ovidius een hachelijke zaak. Het detail is voor de godenschildering ook niet van direct belang. Zeker is, dat Ovidius in belangrijke punten der godenschildering in dit verhaal van Nicander afwijkt. Dietze (p. 26) heeft kortelijk gehandeld over verschillende afwijkingen en de redenen ervan, hoewel niet over de andersgeaardheid van de eigenlijke teekening van Latona.

Nicander spreekt van herders, Ovidius, en dit tot driemaal toe, van boeren (coloni, 318 ; agrestes, 344 ; rustica turba, 348). Bij Nicander wilde de godin haar kinderen baden, bij Ovidius wil zij haar dorst lesschen. Beide wijzigingen hangen ten nauwste met elkaar samen; want voor de herders is het meertje, als drinkplaats voor het vee, een kostelijk bezit, terwijl baden het water zou vertroebelen en ondrinkbaar maken; daarentegen is voor de boeren de helderheid van het water van geen belang, terwijl een dronk eruit het water zelfs niet zal vertroebelen. Ovidius insisteert op beide wijzigingen, uitdrukkelijk vermeldend, dat de boeren in het meertje bezig waren biezen te snijden (344 v.) en het dus niet als een drinkplaats gebruikten, en doordat hij Latona laat verzekeren, dat het niet haar bedoeling is een bad te nemen, doch enkel haar dorst te lesschen (352 vv.). Deze plaatsen bewijzen, dat Ovidius Nicander's versie wel kent en er bewust van afwijkt. Het doel der wijzigingen is duidelijk : vergrooting van de 
schuld der landlieden. Wat bij Nicander nauwelijks een vergrijp kan worden genoemd, dat namelıjk de herders de vreemdelinge uit het water druven - zus worden dan ook niet om deze reden gestraft -, wordt door Ovidius omgezet in zware schuld, want louter kwaadwilligherd. De verzachtende omstandigheden zijn in bezwarende veranderd.

De dichter rondt het motief der kwaadwilligheid naar alle kanten af. Haar verzoek om een weinig water wordt hierdoor voorbereid, dat de godin vermoeid is van den zwaren tocht en ten gevolge van de hitte dorstig, terwill ook de zuggelingen dorst liden. Het vergroot de schuld der hartelooze boeren. Op rekening van Ovidius zelf komt ook, dat Latona in uiterste deemoed smeekt om de gunst van een teug waters, bij Nicander smeekt de godin niet, doch vervolgt haar weg Tenslotte wordt de schuld der boeren ten top gevoerd, doordat zij als antwoord op de bede niet slechts blijven weigeren, nuet slechts gaan dreigen en kuven, doch, uit pure kwaadwilligherd, in het meertje springen en springende het water ondrinkbaar maken. De eenige schuld, die de herders van Nicander treft, 1s, dat Leto hen bij haar terugkeer van den Xanthus aantreft bij het baden, niet het drenken van vee; zij hadden dus aan de vreemdelinge misgund, wat zil aan het vee toestonden, dit maakte hun weigenng schuldig.

Latona wordt dus bij Ovidius ten uiterste vernederd, terwil de godın zichzelve ook ten uterste vernedert door haar bede. Op haar jammerlyken toestand (zuj is slechts een dolende verschoppelinge, bij Nicander is zij op weg naar den Xanthus) en op haar jammerende lijdzaamhe1d wordt alle nadruk gelegd. Wie echter meent, dat de ommekeer er des te grooter om zal zijn, komt bedrogen uit. Aan haar passiviteit verandert bij de bestraffing der schuldigen nauwelyjks 1ets Want, als eindelık de maat vol is, zoo zegt de dichter, als de godın zich niet meer vernedert, - wat zien wij dan? Niet een godin, zich in majesteit wrekend verheffende, zooals wij na de inleidende woorden der penpetie mochten verwachten : zil heft slechts de handen ten hemel en 'aeternum stagno' dixat 'vivatis in isto' (369) Dit zijn de houding en de woorden eener ten uiterste getergde, haar zelfbeheersching verliezende, om wraak ten hemel schreiende vrouw, net het optreden en machtswoord eener godin $Z_{1 j}$ beveelt niet, zij uit slechts een wensch (verwensching); en haar optata gaan in vervulling (370). $Z_{1 j}$ handelt niet; het verband tusschen haar woorden en de volgende straf 13

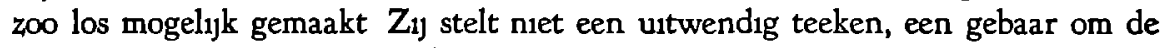
straf aan te geven, zooals dat bijv Diana doet in „Actaeon" door haar slachtoffer met water te besprenkelen. $B_{1 j} N_{1 c a n d e r}$ verandert de godin, in woede ontstoken, de herders in kikkers en dnjft hen, terwijl zil hen met ruwen steen op rug en schouders treft, het water in $B_{1 j}$ Nicander is actie. $B_{1 j}$ Ovidius veranderen de kjuvende springers als vanzelf in kwakende kıkkers. $\mathrm{Al}$ is bij Nicander het gedrag der godin verre van stichtend, al meenen wij eerder een vrouw ut de heffe des volks in actie te zien dan een wrekende godin, bij hem hebben wij, in tegenstelling tot Ovidius, althans met een handelende godin te doen De vermenschelıking der godın bij Ovidius wordt door Ovidius op andere wijze gerealiseerd dan door zijn alexandnjnschen voorganger; in zijn schildenng van Latona als de uiterst lijdzame wijkt Ovidius welbewust van zijn voorbeeld af. 
Heinze (p. 12 n. 2), wijzend op het verschil tusschen de Ovidiaansche en de Nicandreische godin, meent, dat Latona bij Ovidius niet met steenen opereert, omdat dit een Ovidiaansche godin onwaardig zou zijn ; dezelfde beweert, dat Latona zich verheft tot wrekende grootheid. De waarheid is, dat zij zich in het geheel niet tot wrekende grootheid verheft, en niet met steenen opereert, omdat dit niet in de lijn ligt van deze godin, zooals Ovidius haar zich voorstelt, als de erbarmelijke en lijdzame.

Wij mogen ook nog wijzen op de inkleeding van Latona's bede tot de boeren. Haar woorden zijn een typisch Ovidiaansch product, een speelsche show van den habitué der declamatiezaal. Volgens de regelen der kunst worden alle denkbare motieven in een climax gegeven. Eerst stelt zij haar recht vast op water (natuurrecht) ; vervolgens vraagt zij deemoedig om wat zij rechtens kan eischen ; daarna doet $z \mathrm{ij}$, haar ellendigen toestand beschrijvend, een beroep op het medelijden der toehoorders; daarop wijst zij hun op den grooten dank, dien zij hun zal weten voor een kleine gunst; en tenslotte, als knaleffect, het beroep op de smeekende kleintjes: et casu tendebant bracchia nati (359). Het suasorisch karakter harer woorden is te sterk dan dat het niet als zoodanig bedoeld en herkend wil zijn. Doch ook het speelsche, Ovidius eigen, ontbreekt niet. Hij speelt met het beroep op het natuurrecht, op het gemeen bezit van zon, lucht en water, hoogst merkwaardig in den mond eener godin, en dat tegenover ongeletterde boeren. En zooals het spreekwoordelijke posuere penates, van goden gezegd ("Concilium Deorum"), verrassend is, zoo ook het spreekwoordelijke haustus aquae mihi nectar erit (356) in den mond eener nectar drinkende godin. Voor het spreekwoordelijk gebruik zie F. 2.294 : nectar erat palmis hausta duabus aqua.

Verschillende dingen heeft Ovidius van Nicander niet overgenomen, te weten allerlei antiquarische en aetiologische geleerdheid. Evenals de bezwarende om. standigheden heeft Ovidius de actie sterk geconcentreerd. Bij Nicander is er een storende onderbreking in het verhaal : de godin gaat, na uit het meertje verdreven te zijn, rustig haars weegs; de wraals volgt eerst na haar terugkomst van den Xanthus. Doch tusschen de bedrijven is het land Tremilis van naam veranderd, naar de $\lambda u ́ k o l$, die aan de godin den weg wezen, Lycië genoemd, en is na het bad in deze rivier de Xanthus aan Apollo toegewijd. Al deze geleerdheid (evenals den ouden naam van Delos, Asteria, en den naam der bron, Melite) laat Ovidius weg, wijl storend voor de ontwikkeling en afronding van het verhaal. Voor Ovidius komt het verhaal in de eerste plaats; voor Nicander schijnt het vooral een raam te zijn om aetiologische geleerdheid in op te hangen. Ovidius, dichter en verteller in de eerste plaats en dan, voor de leus, geleerd, heeft van zijn model een ander en beter verhaal gemaakt. Juist de afwijkingen bewijzen, dat hij Nicander's versie gekend heeft. Ovidius toont zijn zelfstandigheid tegenover zijn voorbeeld, ook al is dit een alexandrijnsch voorbeeld, en hij toont tevens zijn superioriteit, die op rekening komt van zijn dichterlijke drift, die het essentieele aangrijpt en het bijkomstige verwerpt. Storend is slechts de teekening van Latona als de zwakke, passieve, wier wraak wij nauwelijks zien, ofschoon wij deze mochten verwachten. Doch dit bewijst juist, hoeveel hem gelegen was aan een jammerlijke en jammerende Latona, voor wie hij, als in 
„Niobe”, te rade ging bij Callimachus, naar wien hij daarom in den aanvang van zijn verhaal door een korte recapitulatie van diens Deloshymne ook wel direct verwijst. De groote lijnen van het verhaal ontleende hij aan een alexandrijnsch dichter, zijn idee van de godin an een anderen alexandrijn ; feiten en idee ver. werkte hij zelfstandig. In de opeenvolgende verhalen van Niobe en de Lycische boeren vinden wij een soort Callimacheischen cyclus, die, in de schildering der godin Latona gelijk afgestemd, in de vormgeving verschillen vertoont; want het eerste verhaal is episch gestyleerd, het tweede in eenvoudiger trant verteld, een fraai contrast in eenheid.

Deze geschiedenis wordt verteld door een man uit het volk, hetgeen er een aparte bekoring aan geeft, vooral daar de dichter begint met sfeer te scheppen. Werner (p. 236 vv.) beweert, zonder een schijn van bewijs, dat Ovidius een humoristisch-griezelige "Spinnstubengeschichte" over een heks, die hij uit den mond van eenvoudige lieden had opgevangen, heeft omgezet in een humoristischstichtelijke godenaretalogie, die van de macht der goden moet getuigen; daarbij zou hij de lage volkstoon in litteraire taal hebben omgezet. Van Nicander's versie had deze geleerde blijkbaar niet gehoord. Doch ofschoon hij hiermede genoegzaam blijk geeft van zijn incompetentie in dezen, acht Heinze (l.c.) hem niet te slecht om als bondgenoot te dienen in zijn theorie over de waardig. heid der Ovidiaansche goden. Om zich niet te zeer te compromitteeren, gewaagt hij, in diplomatiek niets zeggende woorden, van "merkwaardige dingen", door Werner gezegd. Wanneer men niet uit eigen ervaring wist, hoe licht men door een vondst verblind raakt, zou het moeilijk vallen, aan $\mathrm{He}$ in ze's goede trouw te blijven gelooven.

\section{BOREAS (VI 682-713)}

De expectoratie van Boreas, die aan den roof van Orithyia voorafgaat, heeft een tweeledig doel : den roof te motiveeren, en Boreas, den wind-god, te karakteriseeren. Boreas was spreekwoordelijk als het type van den grimmigaard:

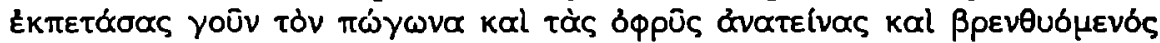

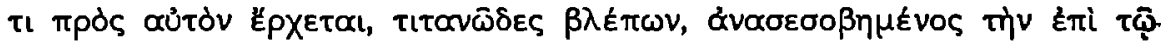

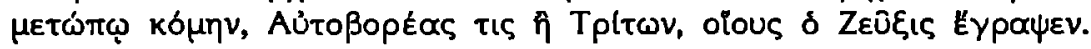

(Lucianus, Timon 54). Als de rapidis inmansuetissime ventis wordt hij in de $17 \mathrm{de}$ Heroide, v. 37, geapostropheerd. Ovidius leidt zijn woorden in met : horridus ira, Quae solita est illi nimiumque domestica vento ( $685 \mathrm{v}$.), en besluit de stormachtige ontboezeming met: haec Boreas aut his non inferiora locutus (702); B Boreas' woorden zijn dus exemplarisch bedoeld; en inderdaad typeeren de bulderende woorden den bulderenden windgod, wiens wapens zijn saevitiam et vires iramque animosque minaces (688) en de juistheid aantoont van zijn stelling: apta mihi vis est (690). De god is even bulderend als zijn wind, of liever : god en wind zijn beiden bulderend, wijl één. Dit namelijk blijkt overduidelijk uit de schildering van Boreas, bij wien het persoonlijke en het zakelijke moment ten nauwste op elkaar zijn afgestemd. Het persoonlijke vinden wij in zijn palle en zijn vleugels, in de vermelding van zijn verwoed worstelen met zijn 
broeders, waarbij de lucht hun worstelperk, hun campus genoemd wordt (694). Doch aan den anderen kant gaat het zakelijke moment niet achter het persoonlijke schuil. Men kan, als men wil, personificatie zien in de epitheta van palle en alae: pulverea en fulvae. Doch Boreas-god en Boreas-wind zijn niet gescheiden in: horridus ira, 2uae solita est illi nimiumque domestica vento: horridus herinnert aan horrifer, door Ovidius enkele malen als karakteriseering van den Noordenwind gegeven $(1.65 ; 15.471)$, terwijl het woord ventus voor zich spreekt. Naar een eigenschap van Boreas-wind wordt ook Boreas-god als gelidus tyrannus (711) omschreven. Dat de dichter met de dupliciteit van den god speelt, bewijst echter vooral de passage, waar hij spreekt van de feller opvlammende ignes, als Boreas zijn geliefde rooft : ignes, dubbelzinnig gezegd, slaat zoowel op de bliksem, die Boreas-wind verwekt, als op het liefdesvuur, dat laait in den boezem van Boreas'god.

\section{CALYDONIUS APER (VIII 273-281)}

Diana zendt den Calydoniërs een geducht everzwijn over, dat land en volk ten gronde dreigt te richten. De godin heeft alle reden, zich gekrenkt te voelen: want zij alleen van alle goden bleef van een goddelijk eerbewijs verstoken. De beslissende vraag is echter, wat de drijfveer harer wraak is. Voor de beantwoording dezer vraag is het woord ambitiosus (277) beslissend.

De goden willen gefêteerd zijn; zij zijn op hun wierook meer dan gesteld. Wat, in de vergadering, die aan den zondvloed voorafgaat, de goden het meest klemt, is de vraag, quis sit laturus in aras Tura (1.248 v.). Ambitiosus wordt in ons verhaal de honor der goden genoemd. Als commentaar kan dienen, wat Flora in de Fasti openhartig bekent : nos quoque tangit honor. festis gaudemus et aris, Turbaque caelestes ambitiosa sumus (5.297 v.). Flora geeft toe, dat, als de goden zich gepasseerd gevoelen, hun toorn de perken te buiten gaat: iustum praeterit ira modum (304); tot illustratie hiervan verwijst zij naar Diana's wraak op de Calydoniërs en op Agamemnon en naar Venus' wraak op Hippolytus. Diana is bij uitstek fel in haar wraak : nihil est violentius illa, Cum sua numina laesa videt, waarschuwt Acontius (Her. 19.99 v.), verwijzend naar de wraak der godin op de Calydoniërs, op Actaeon en op Niobe. De felheid van Diana leeren wij in de Metamorphosen kennen in de verhalen van Actaeon, van Niobe, van den Calydonischen ever en van Chione. Reeds Callimachus vermaande, Artemis niet te veronachtzamen, onder verwijzing naar haar wraak op Calydon (hymne Artemis 260 v.). De Calydonische ever is dus wel het sterkste voorbeeld harer wraak, en dat de menschen zich over de felheid ervan op zijn zachtst uitgedrukt verwonderen, beseft ook Achelous: quoque minus spretae factum mirere Dianae (8.579). Ovidius ziet hierin namelijk niet een vindicatie der goddelijke erkenning, doch een wraakneming uit gekwetste eerzucht : zij is niet gefêteerd, zij voelt zich gepasseerd. Praeterita, inhonorata, spreta wordt de godin in het verloop van slechts enkele verzen genoemd (278/81). Het is een kwestie van sine ture gebleven te zijn (277). Nos quoque tangit honor, zegt Flora van de turba caelestes ambitiosa; tangit et ira deos, zegt de dichter, als Diana haar ambitiosus honor niet heeft gekregen. De wraak is aan gekrenkte 
eerzucht te wijten; ook de goden, zoo geeft de dichter te verstaan, zijn van deze menschelijke zwakheid niet vrij. Tangit et ira deos: het is weliswaar geen Euripideische aanklacht, doch ook niet episch objectief, maar met eenige ironie geconstateerd.

\section{CONVIVIUM ACHELOI (VIII 547-IX 97)}

Achelous geeft ter eere van Theseus, zijn gast, een groot diner. $\mathrm{Z}_{\mathrm{ijn}}$ huis, het huis van een riviergod, is natuurlijk een grot; de wanden zijn van poreuze puimsteen en ruwe tuf; mos bedekt den bodem; het gewelf is met schelpen versierd ; deze materialen passen bij de behuizing van een riviergod, zooals bij

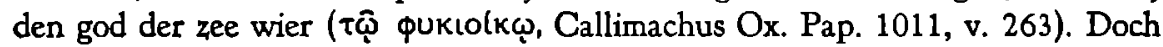
wij vinden er niet enkel natuur, doch ook cultuur, of beter : luxe. Het gewelf is door gedraaide en vlakke schelpen kunstig verdeeld in cassetten, een echt lacunar (lacunabant, 564), en herinnert sterk aan de woningluxe van 's dichters eigen tijd (Ehwald), evenals de slaapkamers der Cecropiden in het tweede boek, (ebore et testudine cultos, $737+\mathrm{Ehwald}$ ). De dichter spreekt dan ook van atrium; het is, naar een woord van Horatius, uitgevoerd novo ritu (c. 3.1 .45 v.). In dit modern-luxueuze atrium ligt men aan als op een Romeinsch triclinium; de dichter geeft ons te veel details dan dat hij ons dit niet wil inscherpen : Theseus heeft de eereplaats, en wordt geflankeerd door zijn vrienden Pirithous en Lelex; voorts zijn er nog andere gasten. Men denkt onwillekeurig aan het diner bij Nasidienus, door Horatius beschreven (s. 2. 8). Het diner eindigt eerst bij zonsopgang (9.93), na reeds in den namiddag begonnen te zijn $(8.565)$; zoo spreekt Horatius van de medio potare die (s. 2. 8. 3). Wij hooren vain een bekoorlijke bediening door nymphen, van den tweeden gang (9.92); de wijn wordt geserveerd in gemma (573): in dit moderne atrium dus, waar het Romeinsch toegaat, behoeft ook het drinkgerei niet onder te doen voor de kostelijkste gemmata potatoria van Rome (cf. gemmas formatas in pocula, Apul. met. 2. 19). Uit een en ander blijkt genoegzaam, dat ons hier een welbewuste en ver doorgevoerde moderniseering geboden wordt, aangepast aan de rustieke omgeving van den riviergod. Het is een charmante mengeling van ars en natura. Deze moderniseering lijkt wel een gril van den dichter, temeer daar de gastheer nu niet bepaald een elegante verschijning is (inornatos crines, 9.3 ; vultus agrestis, 9.96). Waartoe ook al deze details in deze raamvertelling, terwijl gewoonlijk het raam slechts aangeduid, niet uitvoerig geschilderd wordt? ( $\mathrm{S} \mathrm{chm} \mathrm{id} \mathrm{t} \mathrm{p.} \mathrm{102).}$ Wij zullen echter zien, dat de dichter er een bedoeling mee heeft.

Theseus, de "roemruchte Cecropide" (550 v.), wordt door den dichter in het brandpunt der belangstelling geplaatst. Laetissimus hospite tanto (570), richt Achelous een luisterrijk diner aan. Theseus heeft de eereplaats. Ook tijdens de gesprekken wordt Theseus telkens weer genoemd. Een vraag van Theseus lokt het verhaal der Echinaden uit ; het verhaal van Philemon en Baucis roert Theseus het meest; omdat Theseus nog meer wonderlijke daden der goden wenscht te hooren, vertelt de gastheer van Proteus, van Mestra, en van zichzelf; van zichzelf, nadat weer Theseus hem hierom gevraagd heeft. De dichter heeft dit 
alles niet zonder reden zoo beschikt. Om zijn verhaal ten volle te apprecieeren, dienen wij tot Callimachus terug te gaan. Ook deze had beschreven, hoe Theseus onthaald werd, doch niet aan het hof van een der grootste helden, doch in de schamele stulp van Hecale. Met groot verisme geschilderd, was deze ontvangst het lichtend voorbeeld der nieuwe kunst. Het was een groot contrast met de oude epiek, dat zulk een held onder zulken kout als die van het oude besje zulk een bescheiden maal genoot, en dat aan den vooravond van een zijner grootste wapenfeiten; stelselmatig werd alle aandacht op het alledaagsche en armoedige gericht. Het succes van de "Hecale" was groot, en in de alexandrijnsche poëzie werd het gasturije onthaal van een god of held in armelijke omgeving een conventioneel motief. In Eratosthenes' „Erigone" was Bacchus de gelukkige; in het vele, dat ons verloren is gegaan, kwam dit motief stellig herhaaldelijk voor. Voor Ovidius behoeven wij slechts te verwijzen naar de verhalen van Philemon en Baucis en van Hyrieus (Fast. 5.495 vv.). Teekenend voor het conventioneel karakter van dit motief is het volgende: Celeus, die in het verhaal van den Roof van Proserpina een rol speelt, is in de Homerische Hymne op Demeter een koning, zij het een berooide; bij Ovidius echter is hij - misschien naar een alexandrijnsch voorbeeld - tot een gewonen armen boer geworden (Fast. 4. 507 vv.). Al behielden de alexandrijnsche navolgers Callimachus' verisme, het moment der verrassing ging bij hen uitteraard verloren; want wat in Callimachus' tijd een adembenemende innovatie was geweest, werd na verloop van tijd tot een cliché. Thans echter zorgt Ovidius voor een verrassing. Dezelfde Theseus, bij Callimachus op hartelijke, doch armelijke wijze ontvangen, wordt bij Ovidius op even hartelijke, doch uiterst weelderige wijze onthaald. De verklaring van Achelous' luxueus banquet ligt in Callimachus' „Hecale”. Bij Callimachus valt het moment der vermenschelijking en veralledaagsching meer op, bij Ovidius dat der moderniseering, doch beider relaas kenmerkt zich door het moment van het contrast en de verrassing. Doch hierbij blijft Ovidius nog niet staan. Het gastmaal bij Achelous dient als raam voor een reeks verhalen, waarvan dat van Philemon en Baucis een der hoogtepunten is. Hierin nu vinden wij een uitvoerige, Callimacheissche beschrijving van een gulle, doch armelijke ontvangst. Het is algemeen bekend, dat in de verzen, die hierover handelen, Ovidius de "Hecale" vaak op den voet volgt (zie den commentaar van $\mathrm{Eh}$ wald en $\mathrm{Ka} \mathrm{pP}$ in de noten bij de betreffende fragmenten der Hecale). De overeenkomsten willen als zoodanig herkend zijn. Niet zonder reden vermeldt de dichter, dat Theseus door dit verhaal het meest geroerd is (R ibbeck p. 301); hij herinnert zich zijn Hecale. Het aardige is echter, dat de luxe aan Achelous' tafel een weerglans legt op de armoede der oudjes; de dichter kan niet nalaten met het contrast te spelen : omnia fictilibus, post haec caelatus eodem Sistitur argento crater fabricataque fago Pocula (668 vv.) ; men moet daarbij bedenken, dat Lelex zelf den wijn voor zich heeft staan in gemma. De ironie is daarom bij Ovidius sterker en uitdrukkelijker dan bij Callimachus. „Philemon en Baucis”, deze parel, komt slechts in het raam van "Achelous' gastmaal", de zetting, ten volle tot haar recht. Ovidius brengt den grootmeester der alexandrijnsche school een eeresaluut, en dit eeresaluut is zoo fijn en geestig en verrassend als slechts een 
grootmeester kan brengen. Callimachus had het hem niet verbeterd; het is de triomph van Ovidius' alexandrinisme.

\section{ECHINADES (VIII 577-589)}

In woede ontstoken, neemt de rivier(god) Achelous wraak op eenige najaden. Merkwaardig is de versmelting van den god en zijn rivier. De persoon ontsteekt in woede, als kolkende rivier neemt hij wraak. Beide elementen zijn door den naam Achelous overkoepeld. Wij vinden hier hetzelfde als in „Arethusa”, waar Alpheus zijn persoonlijke gestalte aflegt en zich in den Alpheus verandert, in zijn eigen golven, de golven, waaruit hij eigenlijk bestaat ( 5.637 v.). De dichter speelt met de dupliciteit dezer eponyme godheden. $\mathrm{Hij}$ is echter niet aan de hierboven aangegeven opvatting gebonden. Even te voren, bij den aanvang van Achelous' gastmaal, staat de god volkomen naast zijn rivier : de rivier is imbre tumens (550) en vervaarlijk; doch de god is in de beste stemming en geeft een verfijnd diner; de rivier sleurt somwijlen stallen met vee en al mee, zoo waarschuwt de god zijn gasten; hij heeft het met eigen oogen gezien en beleefd : vidi (553). Hier echter, in het verhaal der Echinaden, door hemzelf verteld, heet het : intumui, quantusque feror cum plurimus umquam, Tantus eram pariterque animis inmanis et undis $A$ silvis silvas et ab arvis arva revelli (583 vv.). Het knooppunt tusschen Achelous god en Achelous-rivier ligt in intumui, figuurlijk gezegd van den in woede ontstoken god, en terstond letterlijk opgevat van de rivier.

Wij maken van deze gelegenheid gebruik om op nog enkele andere gevallen te wijzen van spel met de dupliciteit van riviergoden. Wij hooren van een bezoek, dat de rivieren van het land aan Peneus brengen, om hem te condoleeren en te feliciteeren beide (1.577 vv.); wij hebben dus met de goden der rivieren te doen; doch aan den anderen kant wijzen de epitheta dezer goden meerendeels op de rivieren zelf : populifer, inrequietus, lenis. In denzelfden geest spreekt Callimachus van vluchtende riviergoden, doch aarzelt niet, een dezer goden het epitheton zijner rivier te geven ( $\mu \varepsilon \lambda \alpha \mu \psi \eta \eta \phi i \varsigma$, Deloshymne 76). En zooals in intumui een natuurlijk voorval als de expressie van een menschelijk-persoonlijke aandoening wordt geduid, zoo geschiedt dit ook, waar van tranen sprake is : Inachus fletibus auget aquas (1.584); aan lacrimis quoque flumina dicunt Incres visse suis $(11.47 \mathrm{v}$.) ligt eenzelfde gedachte tot grondslag.

De dichter speelt dus met de dupliciteit der eponyme riviergoden, en schept vermaak in de verwarring, die uit dit ver doorgevoerde spel ontstaat.

\section{ERYSICHTHON (VIII 738-878)}

Het verhaal van het vergrijp en de bestraffing van Erysichthon werd door Callimachus verteld in zijn Demeterhymne. Callimachus en Ovidius zijn vaak vergeleken, zie bijv. $\mathrm{L}_{\text {a }} \mathrm{f}$ a y e (p. 132/8). Wegens de groote veranderingen in Ovidius' versie heeft men wel gedacht aan een voorbeeld, door Ovidius gevolgd, dat van jongeren datum was, bijv. Crusius (bij Roscher s.v. Erysichthon 
Sp. 1377) voor de schildering van Fames, doch men dient, zooals vo n Wilamowitz (H. D. p. 43 v.) opmerkt, Ovidius' eigen vindingrijkheid niet te onderschatten : hij is een ster met eigen licht. Wat nu de godenschildering in dit verhaal aanbelangt, Ovidius gaat hierin, tegenover zijn alexandrijnsche bron, en dat nog wel Callimachus, geheel zelfstandig te werk : dit geldt zoowel van de schildering van Fames, als van Ceres, als van de boomnymph. Het meest treft ons hierin het spel met de dupliciteit dezer goden, een alexandrijnsch principe, door Ovidius echter zelfstandig gerealiseerd.

Wij beginnen met de schildering van Fames. Het is een nieuwe, louter poëtische personificatie, niet aan de mythologie ontleend. $\mathrm{Zij}$ is door Ovidius ontworpen en uitgewerkt in een uitvoerige ekphrasis, die door $\mathrm{Zielinski}$ (p. 9) specifiek Romeinsch wordt genoemd, en in elk geval typisch Ovidiaansch is. Alle details zijn afgestemd op het begrip honger. Zooals zijn gewoonte is, zoowel elders als ook in het schilderen van dergelijke personificaties, gaat Ovidius ver in het botvieren van zijn geestrijkheid; wij lezen bijv. ventris erat pro ventre locus (805): dit vindt Ovidius wel het minst, wat men van de verpersoonlijking van Honger mag zeggen. De dichter kan ook niet nalaten te spelen met de dupliciteit van den naam Fames: Fames se ( $=$ famem) viro inspirat (819).

Vervolgens is er de schildering van Ceres. Deze is niet een nieuwe, louter poëtische figuur, doch was reeds lang in de mythologie een persoon met een eigen physiognomie. $Z_{i j}$ is echter door Ovidius gedemythologiseerd, en niet meer de godin der Vruchtbaarheid, doch de personificatie en het inbegrip der Vruchtbaarheid, zooals Ehwald (ad 785) en Zielinski (p. 9) opmerken. Nu was het spel met aan de eene zijde het persoonlijke in Ceres en aan de andere zijde haar functie als schenkster der Vruchtbaarheid aan de alexandrijnen wellicht niet vreemd; wij zijn geneigd, overwegend, dat Ceres' liefde tot Iasion een welbekend motief was, aan te nemen, dat Ovidius speelt met alexandrijnsche motieven, waar hij, in de Amores (3.10), van de liefde van Ceres tot haar beminden jager vertelt : de liefde raakt de persoon in haar, en deze heeft zich zoozeer van haar meester gemaakt, dat zij haar jager even getrouw volgt als Venus haar Adonis; doch zooals een Somnus hèt niet kan helpen, dat hij verschrikkelijk slaperig is - slaap is nu eenmaal zijn wezen -, zoo kan Ceres het niet helpen, dat haar aanwezigheid, de aanwezigheid der diva potens frugum (35), der vruchtbaarheidsgodin, allerwegen het koren laat opschieten, op de vreemdste plaatsen : het Idagebergte staat goudgeel van het koren, de ever maait in de bosschen, Creta heeft een uitermate gezegend jaar, en Minos hoopt van harte, dat Ceres' liefde lang mag duren. Doch nog sterker wordt Ceres in "Erysichthon" opgevat als de Vruchtbaarheid zelve; de verklaring hiervan ligt natuurlijk in den wensch van den dichter om het verhaal symmetrisch te maken: Ceres is de tegenhanger van Fames. De dichter bespiegelt hierover ; beide figuren sluiten elkaar per definitionem uit: neque enim Cereremque Famemque Fata coire sinunt ( 785 v.) en dicta Fames Cereris, quamvis contraria semper Illius est operi, peragit $(814 \mathrm{v}$.). In de rigoureusiteit dezer stelling bespeuren wij het spel met de personificaties. Doch niet enkel in een abstracte stelling komt tot uiting, dat Ceres als personificatie der Vruchtbaarheid is opgevat, doch ook 
in een visueel detail, waarin zij wel de Aarde lijkt, zooals von Wil a mowitz p. 43 zegt, doch waarin wij wel vooral de werking der Vruchtbaarheid moeten zien. Den wensch der nymphen genadig inwilligend concussit gravidis oneratos messibus agros (781). Het is een grandioos beeld : zooals Juppiter door zijn hoofdknik zijn domein, den grooten Olympus, doet sidderen, zoo heeft Ceres' hoofdknik zijn uitwerking in haar werkkring, de vruchtbare velden. (E h wald ad 781). Wij zien in de schildering van Ceres dus, hoe Ovidius met groote vrijzinnigheid een bekende persoonlijkheid uit de mythologie herijkt, en, zooals nieuwe, poëtische personificaties min of meer naar de figuren uit de mythologie ontworpen worden, zoo omgekeerd hier een figuur uit de mythologie omvormt naar de nieuwe, poëtische personificaties, kinderen niet van het geloof, doch der ingeniositeit. De dichter acht dit evenwel geen beletsel, om daarnaast van Ceres' traditioneelen slangenwagen gebruik te maken.

Tenslotte vraagt de boomnymph van dit verhaal onze aandacht. De verhouding van de nymph en haar boom, haar $\delta \rho \tilde{s}, \tilde{\eta} \lambda(\xi)$, mocht zich in de belangstelling der alexandrijnen verheugen. Callimachus hecht er zooveel gewicht aan, dat hij hierover in een groote hymne de Muzen hoogstpersoonlijk ondervraagt, en deze verzekeren hem, dat inderdaad het wel en wee der nymphen ten nauwste verbonden is met het wel en wee van haar boomen (Deloshymne 79/85). De dood van den boom beteekent dan ook den dood van de nymph; z,oo vertelt Ovidius het orthodox in de Fasti : fatum naidos arbor erat (4.232). In „Erysichthon" nu trekt Ovidius uit deze nauwe relatie de uiterste, ietwat gedurfde, doch daarom zeer welkome consequentie, en het is geen naiveteit als van eenvoudige landlieden, doch de reflex van den alexandrinist, als hij spreekt van het bloed, dat vloeit uit de wonde, den boom toegebracht. Hij speelt met wat veel lijkt op de dupliciteit van $\delta$ pús en $\delta$ pức. Als tegenhanger vermeldt hij daarop, dat de zusters dryaden van het slachtoffer cum vestibus atris (778) zich tot Ceres wenden : hier slaat de slinger over naar den uitersten kant van het persoonlijke in deze natuurwezens. Ovidius heeft zijn slinger.

In het verhaal van Mestra, dat met dat van Erysichthon verbonden is, trekt tenslotte onze aandacht de wijze, waarop een erotisch avontuur van Neptunus gememoreerd wordt:

et vicina suas tendens super aequora palmas

849

'eripe me domino, qui raptae praemia nobis

virginitatis habes' ait : haec Neptunus habebat.

In deze laatste woorden steekt een fijne ironie: onze oude bekende, Neptunus, had deze praemia.

\section{ACHELOUS ET HERCULES (IX $1-88$ )}

In de opening van Sophocles' Trachiniae vertelt Deianira huiverend van den geweldigen kamp tusschen den riviergod Achelous en Heracles om haar bezit; er wordt iets goddelijk-grootsch gesuggereerd. Bij Ovidius vertelt Achelous zelf van de worsteling ; en dit geeft er een aparte bekoring aan; het is niet grootsch, doch levensecht. Voor huiver is er geen plaats. Zuchtend begint hij te vertellen, 
en heel het verhaal is gekleurd door zijn penibele ervaringen. Ovidius heeft de gelegenheid aangegrepen om de heroische worsteling te vermenschelijken. Doch niet alleen is de wedkamp vermenschelijkt, Ovidius heeft er zelfs een moderne tint aan gegeven. Achelous betoont zich een gewiekst debater en opereert met alternatieven en antitheses als een volleerd declamator; met puntige woorden drijft hij zijn mededinger, die zich op zijn afstamming van Juppiter beroept, in het nauw : matris adulterio patrem petis : elige, fictum Esse Ioverm malis, an te per dedecus ortum $(25$ v.). Het moet echter erkend worden, dat hij, tot de daad geroepen, van groote kennis der worsteltechniek blijk geeft ( $\mathrm{L}$ a f a y e $\mathrm{p} .123 \mathrm{v}$.); men leze bijv., hoe hij, volgens alle regelen der kunst, zijn positie (statio) inneemt: bracchiaque opposui tenuique a pectore varas In statione manus et pugnae membra parabam (33 v.). Wij mogen annemen, dat Ovidius' tijdgenooten met welgevallen de verschillende manoeuvres der beide worstelaars gelezen hebben. Even menschelijk als Achelous wordt Hercules geteekend : B o is si e r (P.A. p. 376) geeft als zijn indruk, dat hij wordt voorgesteld als een gewoon athleet, niet als held, in den trant van die krachtpatsers, die men den volke vertoont bij openbare spelen. Ovidius maakt dus van een heroische worsteling een arenagevecht. De vertelling wordt gekenmerkt door vermenschelijking, en zelfs wel moderniseering.

\section{HERCULIS APOTHEOSIS (IX 239-272)}

Terwijl het lichaam van Hercules op den brandstapel een prooi der vlammen is, wordt in den hemel een godenraad gehouden, waarin Juppiter Hercules' apotheose aankondigt, welke hierop plaats vindt. Om de behandeling van deze episode door Ovidius te kunnen begrijpen, dienen wij even verder uit te halen. Hercules namelijk, die enisus arces attigit igneas, is een voorafbeelding van Augustus, die zich eveneens door zijn daden de apotheose verwerft (T a y l or p. 164 v.). Horatius schaart Augustus onder degenen, die zich den hemel verdienden, te weten Pollux, Hercules, Bacchus en Romulus (c. 3. 3.9/16) ; dezelfde heroën noemt hij ook elders in verband met Augustus : Romulus et Liber pater et cum Castore Pollux en degene, die de hydra bedwong, Hercules dus (Ep. 2. 1.5 en 10). Dezelfde dichter verklaart op een andere plaats, dat, wat Castor en Hercules zijn voor de Grieken, voor de Romeinen Augustus is (c. 4. 5.35 v.). Herculis ritu keert Augustus uit Spanje terug (c. 3.14.1). Vergilius, in zijn verheerlijking van den heerscher, vergelijkt Augustus met Hercules en Liber (6. 801, 804). Dezelfde ideeën vinden wij bij Livius, die, naar Augustus, den bevorderaar van den cultus van Hercules en Romulus, van Romulus een bevorderaar maakt van den cultus van Hercules : iam tum immortalitatis virtute partae, ad quam eum sua fata ducebant, fautor (1.7.15). Het thema van Hercules' apotheose had dus in Ovidius' tijd een politieke tint, en Ovidius' schildering ervan wordt bepaald door den politieken en adulatorischen inslag, dien wij bij de andere Augusteissche dichters waarnemen. Dit verklaart de officieele sfeer van zijn relaas, de voor Ovidius opmerkelijke stemmigheid en soberheid ervan. De woorden, die Juppiter richt tot de ontroerde goden, kan men het best met 
officieele welsprekendheid betitelen; men kan zich gemakkelijk indenken, dat een Augustus in dezen trant voor een C. of L. Caesar sprak in den senaat :

nostra est timor iste voluptas, 243

o superi, totoque libens mihi pectore grator, quod memoris populi dicor rectorque paterque, et mea progenies vestro quoque tuta favore est. nam quamquam ipsius datis hoc inmanibus actis, obligor ipse tamen.

Bij het lezen van populi rectorque paterque bedenke men, dat Augustus tot pater patriae was uitgeroepen door den senaat, ridderschap en het Romeinsche volk (Fast. 2.127 v.). Door de politieke tendenz van dit relaas wordt ook de merkwaardige houding van Juno verklaard. Hercules' felle bestrijdster als zij steeds geweest was, kon zij uitteraard niet onvermeld blijven. Juppiter noemt haar echter niet bij name, doch spreekt in een diplomatieke waarschuwing van „,iemand", verklarend, dat ook degene, die Hercules de belooning zou willen onthouden, in zijn hart zou weten, dat hij haar verdiend heeft. $W_{i j}$ zijn wel ver verwijderd van de stormachtige scenes tusschen beide echtelieden. Nog verbazingwekkender is echter, dat Juno wat over de apotheose door Juppiter gezegd was non duro vultu had opgenomen, er enkel over ontstemd was, naar haar gelaats. uitdrukking te oordeelen, dat Juppiter op haar gezinspeeld had. Deze plotselinge bekeering van Juno bij Hercules' apotheose is nog merkwaardiger dan die bij de apotheose van Aeneas (zie daar). Officieel en diplomatiek zijn ook de termen, waarin over Hercules' aardsche loopbaan en zijn stoffelijk lichaam gesproken wordt : defunctum terra (254); quodcumque fuit populabile flammae, Mulciber abstulerat (262 v.); mortales Tirynthius exuit artus (268); aeternum est, a me quod traxit, et expers Atque inmune necis nullique domabile flammae (252 v. ; drievoudige variatie van één idee); parte sui meliore (269). In denzelfden geest wordt later over de apotheose van Aeneas gesproken. Tenslotte verwijst de dichter onmiskenbaar naar Augustus zelf : maiorque videri Coepit et a ug ust a fieri gravitate verendus (269 v.). Over het gebruik van augustus door Livius zegt Taylor (p. 165): „The historian applies the epithet augustus to both of these prototypes of Augustus (nl. Hercules en Romulus), apparently intending to make his readers think of the emperor under the new title which had just been conferred upon him. Furthermore, in several passages in the early books Livy uses the word augustus in contrast to humanus in what would seem to be a conscious effort to call to mind the emperor's position". Een voorbeeld is 1.7.9, van Hercules gezegd : habitum formamque viri aliquantum ampliorem augustioremque humana. Het is, na al hetgeen reeds gezegd is, niet vermetel voor Ovidius' gebruik van augustus dezelfde bedoeling aan te nemen.

Wij hebben in Hercules' apotheose dus een fragment officieele epiek. De godenschildering wordt door een officieele waardigheid gekenmerkt, en wijkt daardoor af van hetgeen in de Metamorphosen gebruikelijk is. Wij dienen echter, voor een juiste waardeering van deze episode in het geheel der godenschildering in de Metamorphosen wel te bedenken, dat het uitzonderlijk karakter aan een bijzondere reden te wijten is, en dat deze reden niet is van artistieken aard. 


\section{TURBIDA SEDITIO (IX 418-441)}

De overgang van den Herculescyclus naar het verhaal van Byblis is uiterst gecompliceerd: nadat Iole aan Alcmene van Dryope verteld heeft, verschijnt plotseling Iolaus, verjongd door Hebe op verzoek van Hercules. Als Hebe wil zweren, dat zij deze gunst niet meer zal verleenen, komt Themis tusschenbeide en voorspelt den versnelden groei van Callirrhoë's zonen. Het misnoegen onder de goden om het verleenen van deze gunsten aan slechts een enkele uitzondering groeit aan tot opstandigheid ; Juppiter bezweert den storm, verwijzend naar den ellendigen toestand van zijn eigen zoon Minos; Minos vreest Miletus, Miletus gaat vrijwillig in ballingschap; zijn dochter is Byblis. De overgang is zeer ingewikkeld en gekunsteld, misschien wel als zoodanig door Ovidius bedoeld. Er zijn twee steunpunten in deze reeks salto mortale's: de vertelling van den versnelden groei der zonen van Callirrhoë - in futuralen stijl, een kunstgreep, die bij de alexandrijnen niet ongeliefd was -, en de turbida seditio onder de goden, een farce, spelend met de particuliere favorieten der goden, en met Vergiliaansche reminiscenties doorspekt. Het idee schijnt van Ovidius zelf te zijn, en zeker is het de uitvoering in dit verband. De dichter heeft deze kluchtige gelegenheid niet verzuimd; de farce is niet ongeslaagd. Het punt der ontstemming onder de hemelingen is : cur non aliis eadem dare dona liceret (420). Vier goden worden met name genoemd, die hun candidaten naar voren brengen : Aurora (Tithonus), Ceres (Iasion), Vulcanus (Erichthonius, zijn zoon), Venus (Anchises). Dat Aurora met een stokouden bedgenoot zit opgescheept, is algemeen bekend; Ovidius wijdt er in de Amores een zijner geslaagdste elegieën aan (1.13). Van Ceres neemt hij hetzelfde aan; de liefde van Ceres tot Iasion was niet minder bekend, men zie Amores 3.10 (onder "Erysichthon" vermeld; zie ook Tr. 2. 300). De vermelding van Vulcanus en zijn zoon Erichthonius is waarschijnlijk te wijten aan Callimachus' Hecale; men zie fragment 60 in de verzameling $K$ a p p met de noten bij deze passage (zie ook onder „Herse”). De oude Anchises is onder meer bekend uit de Aeneis. Hoogst vermakelijk is, dat Venus zijn verjonging bedingt met het oog op de toekomst (cura futuri, 424) : de toestand van Tithonus en van Iasion is afschrikwekkend genoeg. Het groeien der ontevredenheid en driestheid wordt goed gesuggereerd door de achtereenvolgende verba : queritur, queritur, poscit, paciscitur. De vier voorbeelden zijn een illustratie en een voorbereiding van de algemeene opmerking : cui studeat, deus omnis habet, crescitque favore Turbida seditio (426 v.). Ecce di immortales! Om het gevaar te bezweren verheft zich Juppiter, en heeft den mond vol van de fata, doch slechts een beroep op den ellendigen toestand van zijn eigen zoon Minos kalmeert de verhitte gemoederen. Wij worden in deze scene gedurig aan Vergilius herinnerd. Daar is in de eerste plaats het beroep op de fata, die zoo kenmerkend zijn voor de Aeneis. Voorts komen ons de nobele verzen in de gedachten van Juppiter tot Hercules over het lot van zijn eigen zoon Sarpedon (10.467/72). Daarbij komt, dat Juppiter's pathetische uitroep quo ruitis? tantumne aliquis sibi posse videtur, Fata quoque ut superet? (429 v.) een duidelijke echo is van Aeneas' bezwerend woord bij Vergilius : quo ruitis? quaene ista repens discordia surgit? O cohibete 
iras (12. 313 v.). Voegen wij hier nog bij, dat de woorden, waarin gesproken wordt over het aanvankelijk gemor (vario sermone fremebant, 419) een herinnering zijn aan de woorden uit den godenraad in Aeneis $\mathrm{X}$, cunctique fremebant Caelicolae vario adsensu (96 v.), dan is het niet vermetel te beweren, dat deze godenraad van Ovidius een parodie is op de bekende plechtige, verheven godengesprekken uit de Aeneis, waarbij Ovidius ter contrasteering den lezer aan Vergilius herinnert. Het is een scherts, doch deze godenraad is teekenend voor de Ovidiaansche goden. Bij plechtige, belangrijke zittingen, bij officieele gelegenheden niet veel meer dan een auditorium en klankbord, een willig werktuig in des heerschers hand (men vergelijke het "Concilium Deorum" in boek I), zijn zij hoogst gevaarlijk, ja zelfs tot turbida seditio, ambitio en arma in staat, als hun persoonlijke genoegens op het spel staan; bij zulk een gelegenheid oreert Juppiter over fata, en slechts de overweging van de eigen huiselijke misère van den oppergod sust de verbittering : hun eigen particuliere belangen en favorieten wegen bij deze goden meer dan het algemeen belang en de wereldpolitiek. $\mathrm{Z}_{\mathrm{ij}}$ zijn niet beter dan de menschen. Dit is, dunkt ons, de zin van deze farce, zij stelt de mentaliteit der goden aan de kaak, al geschiedt dit meer spelend dan bitter-satirisch.

\section{IPHIS (IX 666-797)}

Isis brengt haar vereerster Telephusa de hulp, die zij haar in benarde omstandigheden had toegezegd. Het verhaal van Iphis, die van een meisje in een jongen veranderd wordt, heeft Ovidius wel ontleend aan Nicander (Anton. Liber. 17). Er zijn tusschen de versies van beide dichters echter verschillen. Onbeduidend is de verandering der namen. Van belang evenwel is, dat Leto, die bij Nicander met haar goddelijke macht tusschenbeide komt, door Ovidius vervangen wordt door Isis. Hiermede verviel het aetiologisch moment der Nicandreische vertelling, waaraan echter Ovidius, zooals wij reeds in het verhaal der Lycische boeren zagen, weinig belang hechtte. De reden van deze substitutie heeft reeds $\mathrm{E} \mathrm{h}$ wald (ad 686) gegeven : de eeredienst van Isis was in het Rome van Augustus' tijd mode geworden, en deze exotische cultus mocht zich speciaal verheugen in de belangstelling der Romeinsche dames. Dit blijkt duidelijk uit de gedichten der elegiaci. Delia wendt zich voor haar Tibullus tot deze godin (1. 3. 23/32). Bij een ziekte van Cynthia wijst Propertius haar op de excubiae voor Isis (2.28b. 61). Als Corinna in levensgevaar zweeft, laat Ovidius zich een vertwijfeld appèl richten aan Isis (Am. 2.13.7 vv). Tibullus spreekt van Isis' wondermacht, die blijkt uit de talrijke ex-voto's aan haar tempel. Ovidius belooft munera vota, voorzien van een erkentelijk opschrift. Wat het verhaal dus door de substitutie van Leto door Isis verloor aan geleerdheid, won het aan boeiende actualiteit : de keuze tusschen geleerdheid en actualiteit valt Ovidius niet moeilijk. Het gewijzigd verhaal, thans een aretalogie van de populaire godin, moet naar het hart geweest zijn van Ovidius' tijdgenooten, van de dames in het bijzonder. In de schildering van Isis' gevolg herkenden zij vertrouwde figuren uit optocht en cultus. Menig vereerster moet met warme instemming de verzen begroet 
hebben: dea sum auxiliaris opemque Exorata fero, nec te coluisse quereris Ingratum numen (699 vv.). De Romeinsche details in dit verhaal, dat zich op Creta heet af te spelen, zijn opmerkelijk talrijk en soms hoogst gedurfd; men raadplege slechts den commentaar van $\mathrm{Eh}$ wald. De verklaring ervan is, dat zij aan deze wondergeschiedenis der populaire godin een sterk modern, actueel karakter moeten geven. Het ex-voto, waarover zoowel Tibullus als Ovidius spreken in hun elegieën, ontbreekt ook in dit verhaal niet. Wanneer ons dus een machtige godin geschilderd wordt (met een interessant, exotisch gevolg : ook dit mogen wij niet vergeten), dan geschiedt dat ter wille van Ovidius' tijdgenooten, vooral van de dames, die de dichter met dit verhaal wilde charmeeren.

\section{CYPARISSUS (X 106-142)}

Over het alexandrijnsch karakter van dit verhaal heeft uitvoerig Castig. lioni gehandeld (p. 164/79). De aandacht wordt voornamelijk gevestigd op de schildering van het fraaie hert en hoe Cyparissus het dier vertroetelt. Daarom

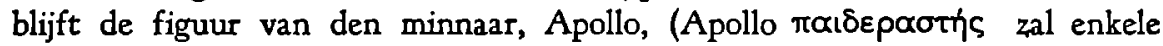
verzen daarna in "Hyacinthus" zijn beurt krijgen) geheel op den achtergrond. In het begin wordt hij even vermeld als de god, qui citharam nervis et nervis temperat arcum (108), en aan het eind worden zijn vruchtelooze pogingen om den knaap tot rede te brengen meer gesuggereerd dan geteekend. De lezer werke de woorden en daden van den trooster zelf uit : quae non solacia Phoebis Dixit! ut hunc leviter pro materiaque doleret Admonuit (132 vv.). De elegieën van Tibullus tot Marathus kunnen daarbij goede diensten bewijzen : vel miser absenti maestas quam saepe querellas Conicit et lacrimis omnia plena madent (1.8.53 v.); - desistas lacrimare, puer - et tua iam fletu lumina fessa tument (1.8.67 v.); - admonui quotiens (1.9.17); - quin etiam flebas - tergebam umentes - usque genas (1.9.37 v.).

\section{GANYMEDES (X 155-161)}

Het tiende boek wordt grootendeels gevuld door een voordracht van den grooten Orpheus. Deze begint zijn recital met een plechtstatig $A b$ Iove, Musa parens, (cedunt Iovis omnia regno) Carmina nostra move (148 v.). Ditmaal is echter zijn onderwerp niet aan het hoogere genre ontleend (plectro graviore) den Gigantenkamp, het supreme voorbeeld van Juppiter's macht en van de hooge epiek (vgl. Am. 2. 1), heeft hij reeds bezongen -, doch zal hij het lichtere genre (leviore lyra) beoefenen : knapen, door goden bemind, en zondige liefdes van meisjes zijn het thema. Dit exordium heeft veel weg van een parodie: Orpheus modern. Bij wijze van ouverture wordt daarop kort de geschiedenis van Ganymedes gerefereerd. Slechts zeven verzen worden aan deze liefde van den oppergod gewijd, doch zij zijn bijzonder ironisch gekleurd. Men zie bijv.

inventum est aliquid, quod Iuppiter esse, 156 quam, quod erat, mallet. nulla tamen alite verti dignatur, nisi quae posset sua fulmina ferre. 
Dit slaat zeer duidelijk op de talrijke metamorphoses van Juppiter verliefd. Heinze (p. 104) merkt op, dat het als een polemiek klinkt tegen andere "Verwandlungssagen". Het is, in feite, een ironisch spel. Juppiter verwaardigt zich enkel de vermomming van den koninklijken vogel, zegt Ovidius om de tegenspraak van den lezer uit te lokken, die maar al te zeer weet, welke onkoninklijke vermommingen de oppergod niet versmaad heeft om tot zijn erotisch doel te geraken : et quidquid magno de love fecit amor (Am. 1.10.7). Het referaat besluit met een verwijzing naar Juno's gepiqueerdheid over den schenker van haar gemaal; Ovidius verwijst hiermede wel naar dezelfde bron, waaraan Lucianus de stof ontleende voor zijn vierden en vijfden godendialoog.

Orpheus' exordium is dus een parodie van het verheven gedicht, en leidt een ironische eerbetuiging in aan het adres van den rex superum, die ook in de knapenliefde honoris causa vermeld wordt. Dat Jupiter slechts honoris causa met zijn Ganymedes vermeld wordt, bewijst, behalve het referaatkarakter van deze passage, het feit, dat er slechts van een vermomming of tijdelijke metamorphose sprake is; deze tijdelijke metamorphose rechtvaardigde de opname in de Metamorphosen, en hierdoor wordt de opmerkelijke aandacht verklaard, die de dichter aan de vermomming besteedt. Volgens $\mathrm{He}$ in ze (p. 104) kan Ovidius zijn lof der knapenliefde niet "wirkungsvoller" openen dan door te toonen, aan welk een vernedering zich om zulk een liefde de hoogste god onderworpen heeft. In feite geeft Ovidius aan Juppiter, dit licht der minnaars, ook in de knapenliefde den eersten prijs en de eereplaats.

\section{HYACINTHUS (X 162-219)}

Over het alexandrijnsch karakter van dit verhaal, evenals van dat over Cyparissus, heeft uitvoerig Castiglion i gehandeld (p. 180/207). Ook in de schildering van den verliefden god maakt Ovidius van alexandrijnsche motieven gebruik. Daar is in de eerste plaats het motief van de verwaarloozing der cultusplaatsen door den verliefden god (zie onder „Admetus") : et orbe In medio positi caruerunt praeside Delphi, Dum deus Eurotan inmunitamque frequentat Sparten (167 vv.). Vervolgens is er het motief, dat de god zich ter liefde van den bemin. den knaap aan allerlei vernederende diensten onderwerpt : inmemor ipse sui non retia ferre recusat, Non tenuisse canes, non per iuga montis iniqui Ire comes (171 vv.). Op deze laatste verzen willen wij iets nader ingaan. De overeenkomsten met de voorschriften, die Tibullus van den expert Priapus ontvangt (1.4), zijn opvallend. Hoe is de verhouding tusschen Ovidius en Tibullus? Castigli on i ontkent, dat Ovidius hier aan Tibullus ontleent; zijn betoog is, in het kort, als volgt : aangezien, eenerzijds, Tibullus de voorschriften van Priapus heeft saam, gelezen uit het bij de alexandrijnen geliefde soort verhalen, waartoe ook dat van Hyacinthus behoort, aangezien, anderzijds, in Ovidius' „Hyacinthus" niet enkel dit motief, doch alle motieven op alexandrijnsche schrijvers teruggaan, heeft Ovidius hier niet aan Tibullus ontleend, doch gaan beider overeenkomsten op gemeenschappelijke bronnen terug. Ofschoon echter de praemissen in groote lijnen juist zijn, is de conclusie slechts ten deele waar. De motieven kende 
Ovidius uit alexandrijnsche dichters, in de verwoording echter wil hij waar. schijnlijk den lezer aan de Priapuselegie van Tibullus herinneren. Vergeten wij niet, dat Tibullus' elegie uiterst geslaagd is, en welk een heerlijkheid het is, naar een eigen Romeinsch dichtwerk te kunnen verwijzen. De betreffende passage bij Tibullus is als volgt :

tu puero quodcumque tuo temptare licebit, 39 cedas : obsequio plurima vincet amor.

neu comes ire neges, quamvis via longa paretur et Canis arenti torreat arva siti.

quamvis praetexens picta ferrugine caelum tventuram amiciat imbrifer arcus aquamt.

vel si caeruleas puppi volet ire per undas, ipse levem remo per freta pelle ratem.

nec te paeniteat duros subiisse labores aut opera insuetas atteruisse manus; nec, velit insidiis altas si claudere valles, dum placeas, umeri retia ferre negent.

si volet arma, levi temptabis ludere dextra; saepe dabis nudum, vincat ut ille, latus.

Er schuilt in deze voorschriften een niet geringe zelfironie des dichters. Volgens

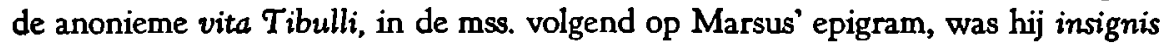
forma cultuque corporis observabilis. Slechts wanneer wij aannemen, dat de dichter inderdaad een homo delicatus was, krijgen verschillende zijner verzen dat relief, dat Tibullus klaarblijkelijk wenschte; bijv. $2.3 .5 \mathrm{vv}$., vooral $9 \mathrm{v}$. nec quererer, quod sol graciles exureret artus, Laederet et teneras pussula rupta manus, hetgeen een merkwaardige overeenkomst vertoont met Priapus' nec te paeniteat duros subiisse labores Aut opera insuetas atteruisse manus. Met Tibullus' agriculturale neigingen, waarmede hij vaak coquetteert, liep het werkelijk zoo'n vaart niet (vgl. nog 1.1.29 vv.). Wat nu de geciteerde passage uit de Priapuselegie zoo delicieus maakt, is de levendige, persoonlijke inkleeding der ironische voorbeelden. Met een fijnen glimlach ziet de god op zijn delicaten en sensibelen discipel neer. Cedas, emphatisch aan het versbegin, neges, ipse, paeniteat, negent, temptabis, het anaphorische nec, het anaphorische quamvis, alles geeft relief aan het penibele dezer manoeuvres; al deze vernederingen om dit eene : dum placeas! Nu geeft Ovidius zijn motieven in geconcentreerden vorm, doch ook met geconcentreerde ironie. Zijn verslag is niet objectief, doch is zeer subjectief gekleurd. Hij constateert hoogstpersoonlijk, zonder de conclusie aan den lezer over te laten, dat Apollo zijn goddelijke waardigheid te grabbel gooit : inmemor ipse sui. Het gebergte, waar de god zijn lieveling vergezelt, is iniquus : het valt niet mee. Zooals Tibullus van nec retia ferre negent spreekt, spreekt Ovidius van non retia ferre recusat; driemaal achtereen gebruikt hij non; de anaphoor nu is een der opvallendste kenmerken van Tibullus' stijl. Wij gelooven daarom, dat Ovidius, ofschoon hij de motieven kende uit de alexandrijnsche dichters, uit wier werken ook Tibullus zijn Priapusvoorschriften heeft saam- 
gelezen, er niet van heeft willen gebruik maken dan in zulke termen, dat de lezer herinnerd werd aan den Priapus van Tibullus. Wat de godenschildering betreft, constateeren wij hier een sterk menschelijke en sterk ironische schildering van het gedrag van den verliefden god, naar alexandrijnsche motieven. Waarschijnlijk voor Ovidius' eigen rekening komt, dat hij uitdrukkelijk constateert, dat Apollo zich gedraagt inmemor ipse sui.

Het vervolg van het verhaal is voor ons van weinig belang. De klacht van Apollo is niet bedoeld als een sterke uiting van smart: Ovidius maakt ervan gebruik om, in alexandrijnschen trant, door middel van de profetie, naar het einde van Aiax te verwijzen en aan de verklaring van de hyacinthusbloem, die hier gegeven wordt, de tweede verklaring te koppelen. Bovendien is de god niet zoo smartelijk getroffen, of hij weet nog scherp juridisch te distingueeren in zake de schuldvraag : quae mea culpa tamen, nisi si lusisse vocari Culpa potest, nisi culpa potest et amasse vocari? (200 v.). Zulk een interessant thema is een kolfje naar de hand van de heeren der declamatiezaal, onder wie Ovidius geen onbekende was. V. 199 gebruikt de god het woord inscribere; "Verbum inscribendi significat delationem et nominis et criminis accusati in libello, quae appellata est inscriptio" (B eck p. 41).

\section{ADONIS (X 525-739)}

In dit verhaal krijgt de godin der schoonheid en liefde haar groote beurt. Haar liefde tot Adonis was een bekend thema. Van een speciaal voorbeeld van Ovidius in dit verhaal is niets bekend.

Ook de verliefdheid van Venus wordt gemotiveerd door een pijl van Amor; het is een ingenieus idee. Daar men niet wel kan aannemen, dat Amor zijn moeder als object zijner pijlen uitkiest, moet de wonde bij toeval veroorzaakt zijn. Dit zou volgens Ovidius geschied zijn bij een omhelzing van moeder en zoon, waarbij hij inscius extanti destrinxit harundine pectus (526). Ovidius verwijst wel naar voorstellingen der beeldende kunsten, speciaal de schilderkunst. Of Ovidius dit thema als verklaring voor Venus' verliefdheid het eerst litterair verwerkt heeft, wagen wij niet te beslissen.

De schildering van het gedrag der verliefde godin is van ironie doortrokken. Evenals Apollo verliefd (zie „Admetus" en „Hyacinthus"), bekreunt ook Venus verliefd zich niet meer om haar cultusplaatsen ( $529 \mathrm{vv}$.) : het is een conventioneel alexandrijnsch motief; of Ovidius het zelfstandig op dit verhaal heeft toegepast, valt niet te zeggen. Ovidius bekroont deze opmerking met de pointe: abstinet et caelo : caelo praefertur Adonis (532). Is de pointe zijn eigendom? Wij vinden ze, na Ovidius, eenige malen bij Nonnus (van Zeus, op Semele verliefd, 8. 3/5 ; van Bacchus, op Ampelus verliefd, 10.307 v., op Beroë, 42. 363/8). De godin is niet van haar Adonis weg te slaan (hunc tenet, huic comes est, 533), en vergezelt haar jager op de jacht. Het is een bekend motief ; hetzelfde hooren wij van Ceres, op Iasion verliefd (Am. 3. 10), van Phaedra (Her. 4.37 vv., 103 v.), van Oenone (Her. 5.17 vv.) ; Tibullus maakt er in zijn Sulpicia-cyclus gebruik van (4.3.11 vv.). Wij hooren dan van het dragen of spannen der netten en 
het aanvuren der honden; dit laatste komt ook in "Adonis" voor. $\mathrm{Nu}$ is het jagerswerk niet licht, en ligt zeker niet in de lijn der weeke, coquette godin : de dichter constateert het met eenige ironie : adsuetaque semper in umbra Indulgere sibi formamque augere colendo ( $533 \mathrm{v}$.), verzen, waarin haar behaagzucht treffend wordt vastgelegd (B o is si er R.R. p. 204 ; L a m a r re p. 189). De teere Venus wordt dus jageres, een soort Diana, althans naar het uiterlijk : fine genu vestem ritu succincta Dianae (536): het wordt met zooveel nadruk gezegd, dat de ironie onmiskenbaar is. De kleederdracht van Diana was uit de werken der beeldende kunsten zeer bekend; Ovidius verwijst er verschillende malen naar, waarbij hij vaak, als een soort epitheton stabile, succincta gebruikt. Talia pinguntur succinctae crura Dianae (Am. 3. 2. 31) : wegens de opgeschorte kleederen waren deze goed te zien, en gerenommeerd geworden. Sprekend over het kapsel van Diana (dus verwijzend naar werken der plastiek), noemt de dichter haar toch succincta (Ars 3. 143). Incincta heet zij Her. 4. 87, waar de kleine wijziging door metrische overwegingen is ingegeven (succincta zou de voorafgaande syllabe positione lang maken). Succincta vinden we ook nog van Diana Met. 3.156. Wil Ovidius de kleeding schilderen van nymphen, dan is een verwijzing naar Diana voldoende: de jageres Syrinx is ritu quoque cincta Dianae (1.695). Een nymph, die dient in Achelous' grot, heet ritu succincta Dianae (9.89). Ritu succincta Dianae, ofschoon dus in zich reeds duidelijk genoeg, wordt echter hier, bij gelegenheid van de jagersbevliegingen van de verliefde, doch eigenlijk zoo

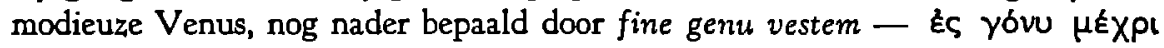

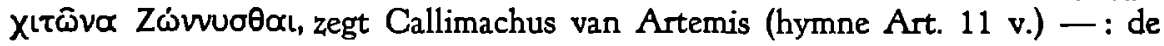
dichter wil het volle pond van dit ironisch geval. - Hoe weinig jagersbloed zij echter heeft, blijkt uit de vermaningen, die zij den beminde geeft : fortisque fugacibus esto' Inquit 'in audaces non est audacia tuta' ( $543 \mathrm{v}$.) ; 'genus omne ferarum, 2 uod non terga fugae, sed pugnae pectora praebet, Effuge.' (705 vv.). Talrijk zijn de gevallen, waarin Ovidius ons van het goede der antitheses te veel geeft, doch in deze verzen in deze situatie missen de geconcentreerde antitheses haar ironisch effect niet. Met beminnelijke ironie en zijn onovertroffen charme schildert de dichter van Amores en Ars vervolgens, hoe Venus de jacht dra gebruikt als aanleiding tot een knus en landelijk minnekozen :

quae causa, roganti 552

'dicam', ait 'et veteris monstrum mirabile culpae;

sed labor insolitus iam me lassavit, et, ecce,

opportuna sua blanditur populus umbra,

datque torum caespes: libet hac requiescere tecum'

(et requievit) 'humo' pressitque et gramen et ipsum

inque sinu iuvenis posita cervice reclinis

sic ait ac mediis interserit oscula verbis.

Dit tafereel, levensecht, in passende, luchtige verzen verteld, even coquet als de coquette minnares, is de godin der liefde en den dichter der liefdeskunst beiden waardig. Het zeugma pressitque et gramen et ipsum is bijzonder gelukkig. Het motief was van alexandrijnschen oorsprong: in den Phaedra-brief verwijst 
Ovidius er naar : saepe sub ilicibus Venerem Cinyraque creatum Sustinuit positos quaelibet herba duos (Her. 4.97 v.). In de Metamorphosen is echter niet meer sprake van ilices, doch van een populier; de wijziging is een verbetering : Horatius (c. $2.3 .9 \mathrm{vv}$.) spreekt van de umbra hospitalis van pinus ingens en alba populus (vgl. Ovidius 10.95 : platanus genialis). Wat aan het volgend verhaal, dat van Atalanta en Hippomenes, zooveel bekoring geeft, is dat wij daarbij nimmer uit het oog verliezen, door wie tot wien en in welke omstandigheden dit verhaal gedaan wordt; door heel het verhaal zijn de persoonlijke noten verspreid; men zie bijv. 579, 679, $681 \mathrm{v}$.

De schildering van Venus in dit verhaal wordt dus gekenmerkt door vermenschelijking en speelsche ironie. Dat Ovidius hierin alexandrijnsche motieven verwerkt, is zeker ; in hoeverre hij dit zelfstandig gedaan heeft, kunnen wij niet meer nagaan. De ironie en de schildering van het minnekozen ademen echter 200 sterk den Ovidiaanschen geest, dat wij het verhaal stellig Ovidius' eigendom mogen noemen. Al speelt hij met alexandrijnsche motieven, hij speelt ermee als - Ovidius.

\section{MIDAS (XI 85-193)}

Uit dit verhaal behoeven wij slechts enkele punten te bespreken. Het eerste is het vers : (Midas) miscuerat puris auctorem muneris undis (125). Auctorem muneris $=$ Bacchum $=$ vinum. De dichter speelt luimig met de dupliciteit van verschillende godennamen, bijv. Vulcanus = god van het vuur, en vuur (armarat deus idem idemque cremabat, sc. Achillem, 12.614) en hier Bacchus = god van den wijn, en de wijn zelf. Het verrassende is, dat hij het gewone proces omkeert. „Bacchus, as god of wine, is freely used by metonomy for wine itself, but wine cannot properly be used for Bacchus. There could be but one step farther in this paradox, „And Bacchus drank himself". (Mille r p. 531). Het is stellig Ovidius' bedoeling, dat dit even door onzen geest flitst, elders deinst hij niet voor dezen laatsten stap in de paradox terug: Sol haat zichzelf, Tellus trekt zich in zichzelf terug, etc. (zie „Phaethon"). Het geval wordt nog ondeugender gemaakt, doordat Bacchus weer omschreven wordt als de schenker der gave, waar in den context alles om draait.

Vervolgens is er de kwestie van de personificatie van den berg Tmolus, die als scheidsrechter fungeert in den wedstrijd tusschen Pan en Apollo. De Ovidiaansche Tmolus is in de poëzie de eerste volledig uitgewerkte eigenlijke berggod (Steuding bij Roscher s.v. Tmolos Sp. 2110). Berg-ding en berg.god zijn deels gescheiden, deels vervloeien zij in elkaar. De conceptie van de personificatie is onvolkomen, meent Miller (p. 529); wij weten niet of wij met den berg of met een van den berg onderscheiden rechter te doen hebben. Als Ovidius van het hoofd van den rechter spreekt, moet men tegelijk denken aan den beboschten bergkop; op deze dubbelzinnigheid maakt ook $\mathrm{S}$ te uding attent. De karakteristiek van (den) Tmolus is zoo onbestemd gehouden, dat het moeilijk is zich daaruit een beeld te vormen, merkt Gerber (p. 302 n. 46) op, die deze onbestemdheid opvat als een mislukte poging van Ovidius tot personificatie 
van een berg, hetgeen koren is op zijn molen, omdat deze geleerde het bestaan van bergpersonificaties ontkent in poëzie en plastiek (daarin tegengesproken door Steuding en Matz p. 117/20). Het is niet te ontkennen, dat wij, aan den eenen kant, met een van den berg onderscheiden persoon te doen hebben:

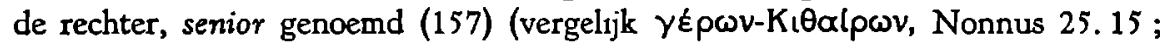
44. 145), neemt plaats op zijn berg; wij lezen, dat hij zijn ooren vrij maakt om beter te kunnen luisteren; hij richt zich eerst tot den eersten aspirant, dan tot den tweeden (163). Aan den anderen kant is hij toch ook de berg: hij wordt dan ook, zoo goed als door iudex, door mons (172) omschreven. Zijn haar wordt caerula genoemd (158) „wegen des bläulichen Duftes, der über fernen Berghäuptern schwebt" (S i e b e l i s-S t a n g e t.p.). Hij heeft een krans niet van eikenloof, doch van heusche eiken om het haar; de eikels hangen hem om de slapen. Het zijn heusche boomen, die hij wegschuift van zijn ooren (157 vv.) ; en als hij zijn hoofd naar Phoebus toe wendt, vultum sua silva secuta est (164). De dupliciteit is welbewust. Zooals Ovidius bij andere eponyme godheden speelt met het reflexivum zich (zich in zichzelf terugtrekken etc.; zie boven), zoo speelt hij hier met het reflexieve possessivum suus: monte suo (157) neemt Tmolus plaats; ofschoon hij zelf de mons is; vultum sua silva secuta est (164): de boomen zijn in zijn hoofd, den bergkop, geworteld. Het is een hoogst groteske personificatie (Ehwald ad 156; Bartholomé p. 59). 's Dichters spotlust en luim om de figuur van den botten Midas werkt blijkbaar nog na in de teekening der andere figuren. Het is hoogst vermakeljjk, dezen vreemden sinjeur te hooren zeggen : 'in iudice' dixit 'Nulla mora est.' (160). En het oordeel van den rechter is vervat in een speelsche variant op de officieele uitdrukking sub. mittere fasces alicui: Pana iubet Tmalus citharae submittere cannas $(171+$ $\mathrm{E} h \mathrm{w}$ ald t.p.) : „de rietpijp voor het snarentuig strijken”.

Ook in de schildering van Apollo in dit verhaal heeft de dichter voor zijn lezers een verrassing in petto:
ille caput flavum lauro Parnaside vinctus verrit humum Tyrio saturata murice palla instrictamque fidem gemmis et dentrbus Indis sustinet a laeva, tenuit manus altera plectrum; artificis status ipse fuit.

De verzen zijn niet alleen plastisch, doch ook naar de plastiek. $Z_{i j}$ beschrijven stellig een beeld van Apollo, dat aan zijn tijdgenooten zeer bekend was. $\mathrm{E} h$ w a $1 \mathrm{~d}$ (ad 164) twijfelt er niet aan, B a r thol o mé (p. 37) vermoedt, dat Ovidius het beroemde, veel bewonderde beeld van Scopas voor den geest heeft, dat door Augustus een eereplaats in Rome had gekregen in den Palatijnschen tempel (zie Platner-Ashby p. 17). Het is ook mogelujk, dat Ovidius het beeld beschrijft van Apollo Citharoedus, van Timarchides, dat, evenals de beroemde beelden der Niobiden, een plaats gevonden had in de aedes Apollinis op den Campus Martius (Platner-Ashby p. 15). Den indruk, dien deze verzen op Ovidius' tijdgenooten gemaakt moeten hebben, kunnen ook wij nog eenigszins navoelen, daar onze gedachten onwillekeurig uitgaan naar het beeld van Apollo Musagetes 
in het Vaticaan. Apollo wordt hier in verheven majesteit geschilderd, doch de reden is iets toevalligs : het schilderen van een vermaard beeld uit de onmiddellijke ongeving van dichter en lezers. Ovidius versmaadt de actueele noot nimmer.

\section{PELEUS ET THETIS (XI 217 vv.)}

Wij bespreken uit dit verhaal slechts enkele details. Dat Thetis onder de worsteling met Peleus andere gestalten aanneemt, is wel interessant, doch leert ons omtrent de godenschildering niets bijzonders. Wat Thetis betreft, willen wij enkel opmerken, dat in de schildering van haar, zittend op een dolfijn, de dichter gebruik maakt van een motief der beeldende kunsten, zooals reeds $E \mathrm{~h} w$ ald (ad 237), onder verwijzing naar Tibullus 1.5 .45 v. noteert. Wat voor ons echter in dit verhaal van het meeste belang is, is de wijze, waarop Juppiter ter sprake komt. De verhouding tusschen Juppiter en Thetis is bekend : omdat volgens een voorspelling de zoon van Thetis grooter zou zijn dan zijn vader, zag Juppiter

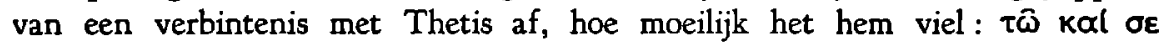

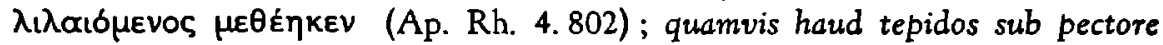
senserat ignes (225). Er schuilt eenig leedvermaak in deze constataties, doch de litotes haud tepidos is verfijnder en effectiever dan de positieve bewering. Hetzelfde verfijnde gebruik van de litotes vinden wij even daarvoren:

$$
\text { nam coniuge Peleus } 217
$$

clarus erat diva nec avi magis ille superbus nomine quam soceri, siquidem Iovis esse nepoti contigit haud uni, coniunx dea contigit uni.

Een kleinzoon van Juppiter te zijn is niets bijzonders; het is het logisch gevolg van Juppiter's talrijke amours; allerwegen struikelt men over de resultaten ervan ; want, zooals Hera bij Apollonius Rhodius tegenover Thetis bitter opmerkt,

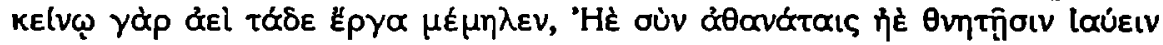
(4. 794 v.). Dit is wat ons de litotes haud uni suggereert.

\section{CHIONE (XI 301-327)}

Chione, een nauwelijks huwbare schoonheid, smaakt het genoegen binnen enkele uren te rusten in de armen van twee goden. Op bijna cynische wijze wordt dit verteld; de berekende eenvoud der vertelling is voor beide goden, voor Mercurius in het bijzonder, vernietigend :

forte revertentes Phoebus Maiaque creatus, 303

ille suis Delphis, hic vertice Cylleneo, videre hanc pariter, pariter traxere calorem. spem Veneris differt in tempora noctis Apollo; non fert ille moras virgaque movente soporem virginis os tangit : tactu iacet illa potenti vimque dei patitur. nox caelum sparserat astris: Phoebus anum simulat praereptaque gaudia sumit. 
De goden maken van hun goddelijke macht misbruik om hun lusten bot te vieren. „The great gods of Ovid are in all the moral attributes of man much more below the average standard of humanity, than the gods and goddesses of Homer are below his human heroes and heroines" (S ell a r p. 351).

Zooveel eer evenwel is Chione naar het hoofd gestegen; zij stelt zich boven Diana, en oefent critiek uit op het gelaat der godin. Deze, met een grimmig factis placebimus (323), schiet haar neer. Diana is de grimmige wreekster bij uitstek (zie onder "Calydonius aper"); de goden zijn, naar een woord van Sella r (p. 351), ,sharp avengers of slights to their vanity".

\section{CEYX ET ALCYONE (XI 410—748)}

Het schijnt, dat Nicander zoo niet de eenige, dan toch een der voorbeelden is geweest van Ovidius in dit beroemde verhaal ( $\mathrm{Ehwald} \mathrm{t.p.).} \mathrm{In} \mathrm{hoeverre}$ Ovidius hem ook in de schildering der goden gevolgd is, onttrekt zich aan onze controle. Wij moeten bespreken Lucifer, Juno en Iris en Sommus.

Als Ceyx, zoon van Lucifer, verdronken is,

Lucifer obscurus nec quem cognoscere posses 570 illa luce fuit, quoniamque excedere caelo non licuit, densis texit sua nubibus ora.

Atmospherische verschijnselen aan Lucifer-ster zijn symptomen van de oudersmart van Lucifer-god. Iets dergelijks vernemen wij van Sol (zie „Phaethon") en van Aurora (zie „Aurora"). Of Ovidius dit motief hier benut naar zijn onmiddellijk voorbeeld dan wel het uit andere verhalen in dit verhaal zelf toepast, kunnen wij niet zeggen; het idee schijnt evenwel van alexandrijnschen oorsprong te zijn (zie onder „Aurora”). Er wordt gespeeld met de dupliciteit van den eponymen god Lucifer.

Het tweede deel van het verhaal wordt op gang gebracht door

at dea (Iuno) non ultra pro functo morte rogari 583

sustinet, utque manus funestas arceat aris,

zendt zij Iris met een opdracht naar Somnus. Peters (p. $27+$ n. 1) merkt op, dat de godin "misericordia non movetur, sed ut funestas manus a sacris aris moveat, Irin mittit. Iuno in Ovidii Mett. semper dura, iracunda, stomachosa est." Wij moeten aan de geciteerde verzen niet te veel gewicht hechten; zij zijn als gelegenheidsmotiveering bedoeld.

Iris is de bode en gedienstige van Juno sedert de alexandrijnen; Callimachus schilderde haar, en in haar nog veel meer haar geduchte meesteres, in zeer vermakelijke verzen (hymne Delos 215 vv.). Als Juno's gedienstige wordt Iris even geteekend in "Ino". Hier is de meesteres wel zakelijk, doch niet onvrien. delijk. ,Iri, meae' dixit 'fidissima nuntia vocis' (585) komt merkwaardig overeen

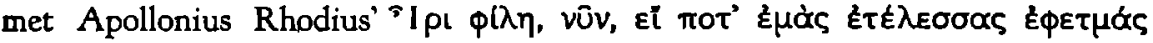
(4. 757), waar 'I $\rho$ i $\phi(\lambda \eta$ (vergelijk uit Theocritus' Adoniazusen, 1, Гopyoî $\phi(\lambda \alpha$, van vriendin tot vriendin), een warm-menschelijke noot is. Iris krijgt een op- 
dracht, en nu zij haar officieele functie gaat vervullen, legt zij wat men zou kunnen noemen haar ambtskleed aan, zooals Mercurius zijn of ficieele uitrusting aanlegt bij een dergelijke gelegenheid (zie „Io") en Tisiphone (zie „Ino"). Iris” kleed is het duizendkleurige (velamina mille colorum, 589). Het natuurverschijnsel van den regenboog wordt omgevormd tot een plastisch persoonlijk attribuut (zooals in "Diluvium"). Vergilius spreekt van den duizendkleurigen boog (mille coloribus arcum, 5.609), Ovidius van een kleed. Was hij hierin de eerste? Is er invloed van de schilderkunst in het spel? Het effect van dit kleed in de duistere grot van Somnus (vestis fulgore reluxit, 617) is in elk geval zeer schilderachtig. Ovidius is echter creatief genoeg, ook in dezen, om zulk een idee ook op eigen gelegenheid te vinden. Door dit kleed worden echter regenboog en godin nauwer met elkaar verbonden: dupliciteit (Peters p. 27).

Of Ovidius' ekphrasis van Somnus en zijn behuizing (592 vv.) op een alexan. drijnschen voorganger teruggaat (dat hij hierin een voorganger had, staat voor $\mathrm{Eh}$ wald ad 592 en vv. vast), kunnen wij niet vaststellen; wij kunnen hem echter confronteeren met Homerus en Vergilius. Homerus geeft van Hypnos' uiterlijk geen details; wel blijkt, dat het een levendig heerschap is, die van een goed feest houdt (XIV 241), verliefd is (276), zich een groote belooning bedingt voor zijn diensten en uitgeslapen genoeg is om Hera haar belofte te laten bezweren bij den Styx $(270 \mathrm{vv}$.). Wat den Vergiliaanschen Somnus betreft (in Aeneis V) : deze is weinig meer dan poëtische beeldspraak. Hij veraanschouwelijkt den strijd tusschen Palinurus' plichtsbesef en een niet meer natuurlijk te noemen aandrang tot slapen. Ook bij Vergilius vernemen wij nauwelijks plastische details : levis wordt hij genoemd (838), komt van de sterren neergestreken (838), neemt de gedaante van Phorbas aan (842), bedwelmt den stuurman met een tak, druipend van Lethe-vocht (854), en wiekt weer weg (ales, 861). Vergilius, zooals vaker, zoekt geen plastische schildering, doch suggereert bovennatuurlijke krachten. Bij Ovidius echter vinden wij een overweldigende opeenstapeling van details; hij wenscht een tableau te ontwerpen, dat zijn doel in zichzelf vindt. Alle details zijn op het begrip slaap afgestemd. Alles, wat slaap verwekt of bevordert, wordt erin betrokken, en alles, wat slaapstorend werkt, wordt als afwezig opgesomd. Het is een poëtisch tableau, geen schildering naar mythologische gegevens. Daarbij ontleent de dichter gegevens, die hem dienstig zijn, aan poëzie en mythologie, doch deze zijn volkomen ondergeschikt aan het idee slaap. Somnus woont niet in een gewoon paleis, doch in een diepe spelonk, waar het dus nachtelijk duister is, en deze spelonk ligt, om het duister nog intenser te maken en Slaap in den nacht te laten leven, in de nabijheid van het land der Cimmeriërs, het duistere. (Zoo leeft Fames (8. 788) in onvruchtbaar Scythië, zoo Apate, volgens Nonnus (8.117), bij de leugenachtige Cretensers.) Of Ovidius in deze localisatie een voorganger had, kan niet met zekerheid gezegd worden; doch stellig had hij in de verzen

quo numquam radiis oriens mediusve cadensve

594

Phoebus adire potest; nebulae caligine mixtae exhalantur humo dubiaeque crepuscula lucis 
de bekende Homerische schildering van het land der Cimmeriërs voor oogen :
クં
11.15

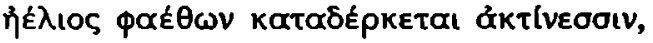

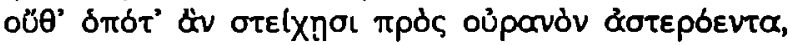

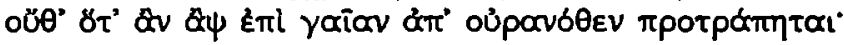

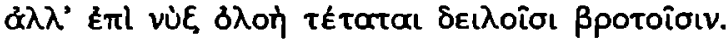

Lemnos, het zonovergoten Lemnos, waar, volgens Homerus, Hypnos verwijlt (XIV 230), komt natuurlijk voor Ovidius' schildering van Slaap niet in aanmerking. Nonnus, in boek 31, waarin hij sterk Ilias XIV benut, vermeldt beide localisaties : of wel ergens in het duistere westen of op Lemnos (112 v.). Uit de mythologie betrekt Ovidius nog een rivus aquae Lethes (603). Volgens $\mathrm{E} h \mathrm{w}$ a Id is dit inconsequent, daar de Lethe in de onderwereld thuis hoort; doch Ovidius noemt slechts een rivus van de Lethe, en Lethe (vergetelheid) en slaap behooren ten nauwste bij elkaar. $\mathrm{E} h$ wa $1 \mathrm{~d}$ veronderstelt, dat de vermelding van de Lethe door Ovidius te wijten is aan den tak, Lethaeo rore druipend, die door Vergilius' Somnus gebezigd wordt; mogelijk, doch evenmin als er van een inconsequentie sprake kan zijn, is een uitwendige aanleiding als verklaring noodig. Men merke verder op, dat sommige details aan Rome herinneren en dus stellig aan Ovidius' eigen fantasie toe te schrijven zijn : er is geen custos bij Somnus' grot (609), en zijn bed bevindt zich in het midden van de spelonk, zooals de lectus genialis in het midden van het Romeinsche huis ( $\mathrm{E} \mathrm{h}$ wald ad 610). Somnus zelf is natuurlijk de slaperigheid in persoon, kan nauwelijks zijn oogen openhouden en knikkebolt, dat het een aard heeft. Zijn aanwezigheid alleen al beteekent, dat men met slaap te kampen heeft (630 v.). De dichter speelt met de dupliciteit van deze figuur, en gaat ook hier tot het uiterste: excussit tandem sibi se (somno Somnum) (621). - In de volgende beschouwingen over Morpheus, Icelos-Phobetor en Phantasos is wel een stuk geleerdheid uit alexandrijnsche poëzie benut.

\section{FAMA (XII 39-63)}

Met zijn beschrijving van Fama's paleis levert Ovidius een pendant van Vergilius' beroemde beschrijving dezer godin (Aen. 4.173 vv.). Doch terwijl Vergilius de aandacht concentreert op de monstrueuze figuur zelf, gaat bij Ovidius Fama geheel schuil achter haar paleis en de activiteit daarin. Bij Vergilius is Fama, als dochter van Moeder Aarde en wreekster harer geknechte broeders de Titanen, ten nauwste verbonden met de mythologie. Ovidius levert een louter poëtische fantasie, los van alle mythologie. In Fama's paleis, de ligging, de bouw, de activiteit en de bezoekers, is plastisch ingekleed de natuur en de werkwijze van de fama loquax (9.137). Het is de Nieuwsbeurs. Door zijn opmerking over het atrium en den stroom van bezoekers en het gonzen der stemmen, geeft Ovidius een Romeinsche kleur aan zijn beschrijving, zooals $\mathrm{Ehwald} \mathrm{(ad} \mathrm{53)} \mathrm{opmerkt;} \mathrm{men} \mathrm{kan} \mathrm{vergelijken} \mathrm{de} \mathrm{salutatio} \mathrm{in} \mathrm{de} \mathrm{paleizen} \mathrm{der}$ aanzienlijke goden (1.172) en bij Aeacus (7.644 v. : in aedibus ingens Murmur 
erat). De personificaties Credulitas, Error, Laetitia, Timores, Seditio, Susurri (59/61), begeleidende verschijnselen van de fama loquax, hebben toepasselijke epitheta, zooals op Apelles' schilderij van $\Delta i \alpha \beta 0 \lambda \eta$ de bijfiguren 'A $A v o i \alpha$,

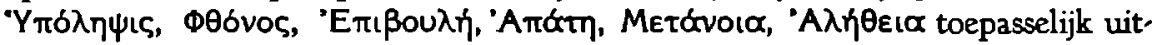
gebeeld waren (Lucian. calum. non tem. cred. 4 ; O ve rbeck No. 1874).

\section{CAENIS (XII 189-209)}

Deze korte vertelling is in den mond van Nestor gelegd; zij vormt den aanloop tot de verhalen, die deze praatvaar, als hoedanig hij in de voorafgaande verzen getypeerd wordt (177 vv.), ten beste gaat geven. De tusschenzinnetjes ita fama ferebat (197) en eadem haec quoque fama ferebat (200) moeten den verteller karakteriseeren. Caenis, een befaamde schoonheid, heeft het ongeluk, tijdens een eenzame wandeling langs het strand, aan Neptunus te behagen, die na gepleegd geweld haar de vervulling van een wensch aanbiedt. In bittere woorden, die van weinig eerbied voor haar aanrander getuigen, doch dichter en lezer een soort boosaardige voldoening geven, vraagt zij, kort, om een man te worden :

'magnum' Caenis ait 'facit haec iniuria votum, 201

tale pati nil posse; mihi da, femina ne sim:

omnia praestiteris.'

In vele opzichten komt haar geval met dat van Coroneus' dochter overeen : zij bijt den verkrachter bitter toe, wat de dochter van Coroneus met melancholische ijdelheid verzucht : forma mihi nocuit (2.572).

\section{MORS ACHILLIS (XII 580-606)}

Dit verhaal sluit nauw aan bij de Ilias en de dichter is erop bedacht, dat het een Homerischen indruk maakt. Van samenwerking tusschen Neptunus en Apollo hooren wij niet enkel in de Metamorphosen bij het bouwen der muren van Troje (11. 202 vv., 12. 587 v.), doch ook in de Ilias (XXI 435/69), terwijl beide goden ook samenwerken bij de verdelging van den wal der Achaeërs (XII 17 vv.). Neptunus herinnert Apollo aan zijn verdediging der Trojanen, uit de Ilias welbekend, en vooral aan de gruwzame mishandeling van Hector's lijk, een bijzonder effectief middel om Apollo warm te maken voor wraak op Achilles : want in de Ilias (XXIV 32/54) protesteert Apollo, tegen den wreedaard op heftige wijze uitvarend, met klem tegen deze onmenschelijke behandeling; op de woorden, die hij bij die gelegenheid bezigt, zinspeelt wellicht ook het vers ille ferox belloque cruentior ipso (592). Neptunus verklaart verder, waarom hij de wraak niet persconlijk ter hand neemt, hetgeen wij toch verwachten mochten: quoniam concurrere comminus hosti Non datur (595 v.), een gelegenheidsmotiveering, ingegeven waarschijnlijk en daardoor betrekkelijk aannemelijk gemaakt door het krasse verbod van Zeus in de Ilias (XV $158 \mathrm{wv}$.). Het is ook niet onwaarschijnlijk, dat nebula velatus (598), van Apollo gezegd, die tot Paris komt, verzonnen is naar een bekend Homerisch motief ; men herinnere zich met name de scene, waar 
Apollo, in dikken nevel gehuld, Patroclus weerloos maakt (XVI 790 vv.) : uit een nevel genaakt het noodlot hier ook Achilles. Op enkele andere Homerische reminiscenties zal nog hieronder gewezen worden.

De dood van Achilles is, zoo stelt Ovidius het voor, in laatste instantie te wijten aan Neptunus. De verklaring hiervan ligt in het voorafgaande verhaal, dat van Cygnus, door den Peleide gedood: Cygnus is de zoon van Neptunus. Tusschen Cygnus' dood en dien van Achilles ligt nagenoeg de gansche Trojaansche oorlog, doch over deze tijdsspanne glijdt de dichter, na een lange tusschenvertelling van Nestor, heen met een snel iamque fere tracto duo per quinquennia bello (584). Neptunus heeft een persoonlijke grief tegen Achilles: hij wrokt mente patria (582), en blijft onmatig lang wrokken : hij is niet odio civiliter usus (Tr. 3. 8. 41), doch volhardt in zijn memores plus quam civiliter iras (583): al te menschelijk; B oissier (R. R. p. 204) kan om zulk een god een glimlach niẹt onderdrukken; L a m a r r e (p. 189) spreekt van een verwijt. Doch wel niet enkel, omdat het een gelegenheidsmotiveering is, legt de dichter op Neptunus' ressentiment zulk een nadruk : de drijfveeren der goden plegen bij Ovidius in het algemeen van zeer persoonlijken aard te zijn. Een soortgelijke opmerking moeten wij ook over het volgende maken. Neptunus spreekt Apollo aan met o mihi de fratris longe gratissima natis (586); en Apollo gaat op zijn voorstel in animo pariter patruique suoque indulgens (597). Het is, zooals gewoonlijk, al familierelaties, wat de klok slaat ; het sluit hier echter tevens volkomen aan bij de llias: XXI 435/69 verklaart Apollo, dat hij niet wil strijden tegen Poseidon, zijn

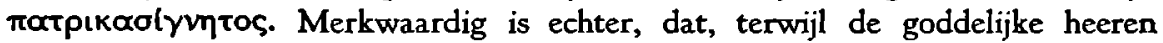
zelf elkaar hun verwantschap belijden, de dichter over hen slechts spreekt in hoogepischen stijl. Neptunus wordt als de machtige god van de zee aangeduid in een vol vers: at deus aequoreas qui cuspide temperat undas ( 580 ; cf. cumque tridentigero tumidi genitore profundi, 11.202). Apollo wordt geintroduceerd in het episch-breede vers talibus intonsum conpellat Sminthea dictis (585), dat ostentatief Homeriseerend is: intonsus is de vertaling van

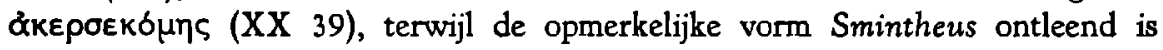
aan Chryses' bekende gebed in Ilias I 39. Deze hoog'epische, Homeriseerende wendingen bereiden aan den eenen kant stellig de Homerische motieven voor, die Ovidius in dit verhaal nog gaat gebruiken, doch aan den anderen kant is het eigenaardig contrast tusschen de epische velleiteit des dichters en den nadruk op de familierelaties in de woorden der goden zelf zoo opvallend, dat het wel niet toevallig is. Ovidius spitst zoo het moment der vermenschelijking, dat in het gewicht der familierelaties ligt, toe, spelend niet slechts met Homerische reminiscenties, doch ook met de zeer persoonlijke gevoeligheden en besognes der goden.

\section{AURORA (XIII 576-600)}

Aurora's groote smart om haar gesneuvelden zoon Memnon openbaart zich in atmospherische verschijnselen:

vidit, et ille color, quo matutina rubescunt 581

tempora, palluerat, latuitque in nubibus aether. 
Iets dergelijks wordt ook opgemerkt over den treurenden Sol (2.329 vv.; zie „Phaethon") en over den treurenden Lucifer (11.570 vv.; zie „Ceyx et Alcyone"). Het is het spel met de dupliciteit van de Dageraadsgodin ; E h w a ld

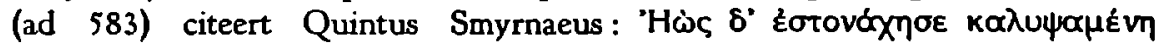

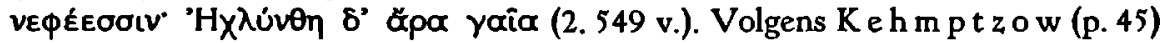
gaan beide passages terug op een alexandrijnsch voorbeeld.

Aurora wordt omschreven als lutea mater. E h w ald (ad 579), evenals P e ter (ad Fast. 4.714), meent, dat lutea een vertaling is van het Homerische

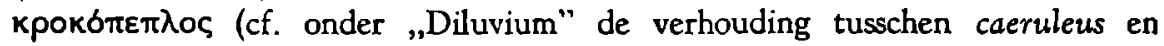
kuavoxa(tगS). De verklaring lijkt op het eerste gezicht plausibel. Want, aan den

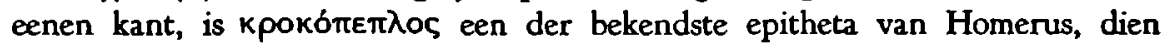
Ovidius uitstekend blijkt te kennen, aan den anderen kant is, bij het spaarzaam gebruik, dat de Romeinsche dichters van composita maken, een Latijnsch simplex voor een Grieksch compositum niet bevreemdend. Toch is bij nader toezien de toedracht van zaken geheel anders. $\mathrm{Ehwald}$ 's verklaring veronderstelt, dat Ovidius, hier althans, zich nauw bij Homerus wil aansluiten; hetgeen niet het geval is. In de eerste plaats speelt Ovidius in deze passage met de dupliciteit van Aurora ; en waar hij spreekt over ille color der godin, ligt het meer voor de hand, bij lutea aan de godin zelf te denken dan aan haar kleed. Bovendien is, in het algemeen, het verschil tusschen het Homerisch gebruik van epitheta voor de Dageraadsgodin en dat van Ovidius hemelsbreed. Wordt Homerus geken, merkt door een onverstoorbaar regelmatig, door de traditie vastgelegd

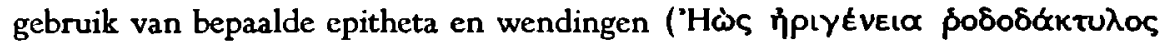

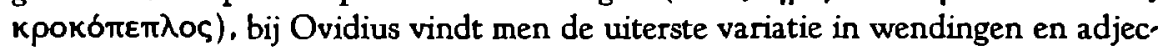
tiva. Wij vinden bij hem niet enkel luteus, doch ook purpureus, croceus, roseus, flavus, roscidus, udus, pruinosus. En deze adjectiva worden niet enkel gevoegd bij Aurora zelf (Aurora, 7.703; dea, A. 3.180; A. 3.84 ; mater, 13.579 v., F. 4.714), doch ook bij afzonderlijke lichaamsdeelen of bij attributen, bij ore (7.705 ; E. P. 1. 4. 58), genis (F. 3. 403), capillis (A. 2. 4. 43), manu (A. 1. 13. 10), bij amictu (A. 3. 179), equis (A. 1.8. 4; F. 4. 714), rotis (3. 150), axe (A. 1. 13. 2). En daarbij behoort niet dit bepaalde epitheton bij dit bepaalde detail, doch hetzelfde adjectief staat nu eens bij dit, dan weer bij dat detail, en hetzelfde detail heeft nu eens dit, dan weer dat adjectief. Als het ware jaloersch op zijn vrijheid, put Ovidius zich uit in variaties, slechts dit eene vermijdend, dat hij in het vaarwater komt van den vader der epiek. Over Dageraad's rozevingers spreekt hij niet, wel over haar purpurea manu. De eene keer, dat hij over haar gewaad spreekt, in de Ars, handelend over de verschillende gewaadskleuren, verwijst hij naar Homerus (hetgeen iets anders is als : sluit zich bij hem aan), doch merk op, hoe hij in de aanvulling de Homerische banen verlaat : croceo velatur amictu, Roscida luciferos cum dea iungit equos (3. 179 v.). Om elken twijfel te bezweren, willen wij het bovenstaande nog wat nader uitwerken; en beginnen met de ontzenuwing van wat een argument zou kunnen lijken voor de interpretatie luteus =

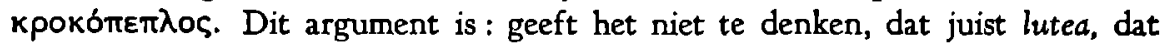
driemaal van Aurora gebruikt wordt (7. 703 ; 13.579 ; F. 4. 714), steeds van de geheele godin gezegd wordt, en niet van een detail? Neemt lutea niet kennelijk 
een uitzonderingspositie in? - Lutea neemt inderdaad een uitzonderingspositie in, doch wegens de metrische geaardheid van het woord, dat slechts in zeer beperkte gevallen voor den hexameter geschikt is. Als wij afzien van den nom. sing. masc. (slechts bruikbaar, indien us niet positione lang wordt door het volgende woord) en van gevallen van elisie, komen voor plaatsing in het dacty. lische vers slechts in aanmerking de nom. en voc. sing. fem. en de nom., acc. en voc. plur. neutr. Om technische redenen moest Ovidius zich voor luteus dus beperken tot den nom. sing. fem. In andere namvallen bezigt hij croceus, dat, omgekeerd, in de bruikbare naamvallen van luteus wegens de opeenvolgende drie korte syllaben onbruikbaar is. Om technische redenen, terwijl daarnaast de variatie van adjectiva hem ook zeer welkom zal zijn geweest, gebruikt Ovidius dus voor saffraangeel twee epitheta, luteus en croceus. Bezien wij nu de gevallen, waarin Ovidius croceus bezigt, dan zien wij, dat hij, ondanks zijn kennis van

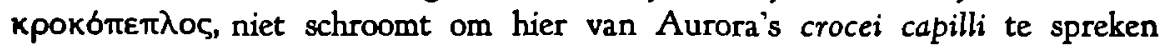
(A. 2. 4. 43), daar van haar croceae genae (P. 3.403), elders van de croceae rotae van haar wagen (3.150): een treffend staal zijner variatie. Ook biedt het gebruik van roseus een treffende parallel. Natuurlijk kent Ovidius het Home-

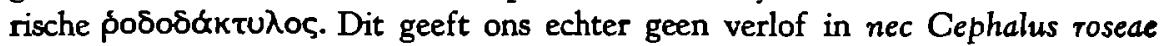

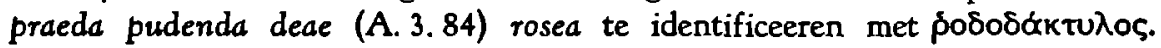
Ovidius leert ons anders. Hij noemt haar paarden rozig (A. 1.8.4 ; F. 4. 714), en en als hij het woord op haarzelf betrekt, spreekt hij niet van haar rozevingeren, doch van haar rozig gelaat (roseo spectabilis ore, 7.705 ; roseo ore, E. P. 1. 4. 58); en, sprekend over Sol's paleis, vermeldt hij Aurora's plena rosarum Atria (2.113). Zoo leert ook roseus, dat de dichter niet gebonden is aan de Homerische voorstelling van zaken. Het zou daarom hoogst bevreemdend zijn, indien Ovidius met luteus, tegen zijn gewone doen in, plotseling aan het Homeriseeren sloeg. De overeenkomst tusschen beide dichters is van elementairen aard, berust op het natuurphenomeen, niet op litteraire afhankelijkheid. Indien lutea al gespecificeerd zou moeten worden, dan zou eerder, gezien Ovidius' manier, een lichaamsdeel in aanmerking komen, dan haar kleed. Het spel met de dupliciteit van Aurora beperkt zich niet enkel tot ons verhaal. Zoo spreekt hij van roscida dea (A. 3. 180); dat wij hier roscida niet mogen interpreteeren als dauwbrengend, doch strikt als dauwig, dauwend, bewijzen passages als : croceis rorare genis (F. 3. 403) en : udis veniens Aurora capillis (5.440). In onze passage sluit, zooals gezegd, de interpretatie van luted als saffraangeel aan bij ille color, terwijl de gedachte aan Memnon, haar zwarten zoon, zoowel hier als in de geciteerde plaats der Fasti, er wellicht nog een extra pikante noot aan geeft.

Tenslotte moeten wij bespreken haar smeekbede tot Jupiter. Hierin steekt, als ik het wel heb, een actueele noot. Haar woorden vormen een strak gesloten betoog, dat sterk herinnert aan Latona's beroep op de Lycische boeren (zie „Lycii coloni”). $\mathrm{Z}_{\mathrm{ij}}$ wijst, aan den eenen kant, op het feit, dat zij ongeëerd is, aan den anderen kant op haar belangrijke diensten, welke haar recht op eer geven; zij vraagt echter niet om haar recht (tempels etc.), doch enkel om een gunst, en wel als eerbewijs voor den edelen Memnon, gevallen in den strijd voor zijn oom, en als troost voor haar treurend moederhart : beroep op het medelijden. De ars tanta 
precandi (Stat. Th. 7.214) wil als zoodanig herkend zijn: Als om het kunstig karakter van haar betoog te onderstrepen, legt Ovidius haar den rhetorischen terminus technicus status ( $=$ otóois, opzet) in den mond: sed non ea cura neque hic est Nunc status Aurorae, meritos ut poscat honores (593 v.). Doch dit is niet alles. $Z_{i j}$ handelt waarschijnlijk ook volgens de voorschriften der rhetoren in heel haar houding. In deze richting wijst wellicht genibus procumbere non est Dedignata $(585 \mathrm{v}$.$) , met het opmerkelijke dedignata: immers, is het$ zoo vernederend, een knieval te doen voor den oppergod? Om haar beroep op Juppiter's medelijden kracht bij te zetten, verschijnt zij ook voor hem zoo deerniswekkend mogelijk : crine soluto. Door de schildering der smeekelinge wil Ovidius ons voorbereiden op het kunstig pleidooi, dat volgen gaat. Ovidius heeft zich, in den trant der declamatiezalen, de opgave gesteld: „Wat Aurora tot Juppiter zeide, pleitend voor een eerbewijs voor den gevallen Memnon." Van den bijval van vrienden en tijdgenooten mocht hij zich verzekerd houden. Ook aan de goden leeft Ovidius de mode van den dag uit. Dat de -smeekende Aurora aan Thetis herinnert, smeekend tot Juppiter in Ilias I, is wel toevallig; de dichter heeft althans geen bewuste imitatie van Homerus willen geven, of stellig niet in de eerste plaats, hoogstens hem willen verbeteren. De voetval is niet beperkt tot Thetis alleen : zoo doet elke smeekeling. Omnibus inferior quas sustinet

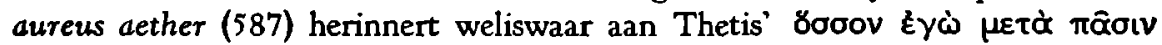

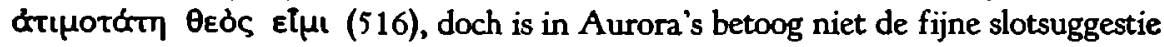
als bij Homerus, doch de aanloop tot een redeneering, gemotiveerd door nam mihi sunt totum rarissima templa per orbem. Hier staat tegenover, dat Aurora niet, zooals Thetis (501), Juppiter bij de kin vat, en dat ook van crine soluto bij Homerus geen sprake is. Ovidius wil niet een Homerus-imitatie, doch iets nieuws, iets, waarin de velleiten van zijn eigen tijd geprojecteerd zijn.

\section{GLAUCUS (XIII 898-968)}

De ontmoeting tusschen Glaucus en Scylla herinnert in groote lijnen sterk aan die tusschen Apollo en Daphne, Juppiter en Io, Pan en Syrinx, de speelsche trits uit het eerste boek : een god ontwaart en begeert een schoone, tracht haar voor zich te winnen, doch zij gaat aan den haal (vgl. met 906/8 en 966 v., de vv. $490,589,699$ v., 502 v., 525 v., 539 uit boek I). Het verhaal van Glaucus behoort dus tot die reeks luchtige, speels vertelde verhalen, die bij de alexandrijnsche dichters 200 populair waren. Welke schrijver, eventueel schrijvers Ovidius' voorbeeld waren, kan niet achterhaald worden. Men heeft aan Callimachus (Glaucus) gedacht, doch E. Rohde (p. 132 n. 2) bestrijdt dit. Alle controle-materiaal ontbreekt ons. Men kan ook denken aan Alexander Aetolus,

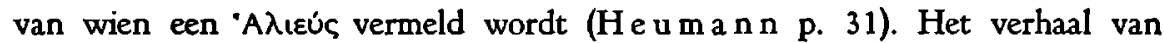
Glaucus is door Ovidius met evenveel ironische gratie verteld als de andere verhalen dezer reeks. De ironie steekt vooral in de situatie, die ontstaan is na de vlucht van de begeerde, en in het feit, dat Glaucus zelf zijn levensloop vertelt. Als het meisje een veilige plaats heeft bereikt, blijft zij staan en aanhoort Glaucus' relaas. De situatie is pittoresk : zij op een rots, die uitsteekt in zee en 
door boomen overschaduwd wordt, hij beneden, zich op de dichtstbijzijnde klip heffend; Scylla neemt met verwondering de vreemde gestalte op (wij zien den god door haar oogen). Inspireerde Ovidius zich op schilderstukken, die op hun beurt op alexandrijnsche dichters geïnspireerd waren? In de villa Hadriani (Ehwald ad 911), op een schildering van dit paar, is de situatie aldus, dat Scylla aan het strand staat. De Ovidiaansche scenerie is verfijnder van ironie: de druiven hangen te hoog; ook schilderachtiger : zij herinnert sterk aan de scenerie uit het verhaal van den verliefden Cycloop (13.778/87: landtong in zee, hierop Polyphemus en zijn kudden; schuilend onder de rots, de aanbeden Galatea op den schoot van haar Acis).

Bij de ironie der situatie voegt zich de ironie der vertelling. Glaucus zelf verhaalt, op levendige, charmante wijze. $Z_{i j n}$ keuvelen staat in fijn contrast tot het wonderbaarlijke, dat hij vertelt. Men leze bijv., hoe de god, vroeger een ¿̀ंıús, over zijn voormalig handwerk spreekt : ante tamen mortalis eram, sed, scilicet altis Deditus aequoribus, tantum exercebar in illis (920 v.). Van deze gracieuze urbanitas is het gansche verhaal doortrokken. Alle huiver of grootschheid ontbreekt. Het verhaal, dat Glaucus over zichzelf doet, is een geslaagde tegenhanger van dat van Arethusa in boek V over haarzelf : menschelijk, glimlachend ironisch.

Een treffend staal van alexandrinisme is het volgende: de goden verzoeken Oseanus om Glaucus te lustreeren, opdat hij een god worde. Na een negenvoudig over hem uitgesproken reinigingsformule (over tooverspreuken zie onder "Circe") wordt hij door liefst honderd rivieren rein gewasschen. De lustreerende kracht van alle rivieren (die hun oorsprong hebben uit Oceanus en Tethys, vgl. Hes. Theog. 537) wordt met speelsch rationalisme als het ware samengebundeld bij deze ongewone lustratie, waarbij het om niets minder gaat dan om een vergoddelijking. Geen wonder, dat Glaucus onder een dergelijke behandeling het bewustzijn verliest. Het is te betreuren, dat wij in deze scene Ovidius niet met zijn voorgangers kunnen vergelijken.

\section{SIBYLLA (XIV 101-153)}

De Sibylle is een geheiligde figuur uit het Romeinsche verleden. Ovidius staat in dit verhaal op eigen beenen. Het is dus van veel belang voor een onderzoek naar Ovidius' godenschildering.

Vergilius had in Aeneis VI de indrukwekkende zieneres groots uitgebeeld. De tocht van Sibylle en Aeneas behoort tot het verhevenste der Romeinsche poëzie. De Sibylle is horrenda (10), Phoebi longaeva sacerdos (628, vgl. 321, 544), nec mortale sonans $(50)$ : na een indrukwekkende vermaning van haar, terwijl den Teucriërs een koude rilling door de leden vaart, bidt Aeneas tot Apollo, en wendt zich ook tot de sanctissima vates (65), de alma (74): te quoque magna manent regnis penetralia nostris (71). Als echter Aeneas bij Ovidius haar belooft, dat zij hem numinis instar (124) zal zijn, geschiedt dit in een gesprek, waaraan alle verhevenheid vreemd is : 
inde ferens lassos adverso tramite passus 120

cum duce Cumaea mollit sermone laborem.

dumque iter horrendum per opaca crepuscula carpit, -

Het is adembenemend gewoon ; een volslagen contrast met de visionaire epiek der Aeneis. Juist de achtergrond van de Aeneis geeft aan Ovidius' voorstelling van zaken iets welhaast profaneerends; het is de veralledaagsching van het sublieme. Op Aeneas' belofte van goddelijke eer reageerend, respicit hunc vates et suspiratibus haustis (129) doet zij haar verhaal, dat geheel in het teeken staat van dit zuchten, waaraan de weemoed om het onherstelbare charme verleent en waarin het spijtig zelfverwijt soms comisch aandoet : tot mihi natales contingere vana rogavi; Excidit, ut peterem iuvenes quoque protinus annos (138 v.). Driehonderd jaren resten haar nog, en steeds meer zal zij ineenschrompelen, en met ontzetting ziet zij het reeds voor zich: nec amata videbor Nec placuisse deo, Phoebus quoque forsitan ipse Vel non cognoscet, vel dilexisse negabit (149 vv.). De groote Sibylle is tot een oude bes geworden, en is van ijdelheid niet geheel vrij te pleiten.

Dit nu is het verband en de sfeer, waarin van Apollo en de Sibylle verteld gaat worden : iets verhevens kunnen wij kwalijk verwachten. Het verhaal van Apollo's liefde tot de Sibylle schijnt Ovidius in groote lijnen ontleend te hebben aan het vierde boek van Varro's Antiquitates Rerum Divinarum (E hwald ad 132). Het was cen pius amor, hetgeen zelfs in Ovidius' versie, ondanks de verregaande wijzigingen, nog blijkt; want door de overlevering gedwongen kon hij van de Sibylle geen Daphne maken, die het slachtoffer dreigt te worden van Apollo's geweld. Apollo's onderhandelingen met haar boden hem evenwel andere mogelijkheden, die hij niet verzuimd heeft te benutten. Apollo biedt haar de vervulling aan van een wensch : dit is volgens de overlevering; zij vergeet bij haar wensch om in één adem tevens om eeuwige jeugd te vragen : hier ziet de god zijn kans: hij biedt deze alsnog aan, doch op voorwaarde si Venerem paterer; dit is minder pieus. Over Apollo's aanbod en zijn bedoeling wordt aldus gesproken : dum tamen hanc (sc. virginitatem) sperat, dum praecorrumpere donis $\mathrm{Me}$ cupit, 'elige' ait (134 v.). Dit herinnert aan Tereus' eerste opwelling, als hij in wilde hartstocht ontbrand is tot Philomela: impetus es illi comitum corrum. pere curam Nutricisque fidem nec non ingentibus ipsam Sollicitare datis totum. que inpendere regnum (6.461 vv.) en aan Cephalus' machinaties, die vermomd de trouw zijner gemalin op de proef stelt : donisque pudicam Sollicitare fidem (7. $720 \mathrm{v}$.$) ; census dare me pro nocte legendo Muneraque augendo tandem$ dubitare coegi (739 v.). Cephalus handelt, zooals $\mathrm{E} \mathrm{h}$ wald t.p. opmerkt, als de dives amator der Romeinsche elegie. Zoo wordt ook hier Apollo geteekend als de dives amator uit Ovidius' eigen tijd: vermenschelijking en moderniseering. Enkel de overlevering stond Ovidius niet toe, de Sibylle te laten zwichten; doch hoe zwaar het haar gevallen moet zijn, kunnen wij nog uit de ontboezemingen der oude bes opmaken. Ovidius teekent dus, in een verband, waaraan reeds alle verhevenheid ontnomen is, een verheven figuur uit de nationale geschiedenis als een gewone oude bes, en een verheven god als een eleganten 
rijken jongeling uit de frivole kringen van zijn eigen tijd; hij doet dit tegen den achtergrond van het verhevenste boek der Romeinsche poëzie, en hij doet dit op eigen gezag, met eigen middelen, in een verhaal, dat hij zelf het eerst poëtisch bewerkte, waarin hem dus geen directe 'slechte voorbeelden' verleiden konden. Het is een hoeksteen in de studie van zijn alexandrinisme, dat niet op rekening komt van gecopieerde voorbeelden, doch een vrijwillig (men zou bijna zeggen : moedwillig) gekozen kunstrichting is, waarvan hij de principes niet aarzelt toe te passen op zelfs de meest geheiligde nationale overleveringen. Zoo goddelijk hoog Vergilius klom, zoo menschelijk laag daalt Ovidius af. Voor den ouderwetschen Romein moet deze vertelling, zoo geslaagd als zij is in haar soort en daarom zoo verderfelijk, een gruwel geweest zijn en een heiligschennis, schreiend om wraak, zoodat zij met de zwaarste verbanning nog licht gestraft werd.

\section{CIRCE ET ULIXES (XIV 247-307)}

In de bespreking van dit verhaal zullen wij ook opmerkingen vervlechten over de schildering van Circe in het verhaal van Glaucus en Scylla (XIV 1-67) en dat van Picus (320-434).

Ovidius heeft het verhaal van Circe en Ulixes in zijn Metamorphosen ingelascht, gebruik makend van een motief van Vergilius in Aeneis III, waarop hij voortborduurt. Bij Vergilius (590 vv.) ontfermen zich de Trojanen over Achaemenides, een van Ulixes' gezellen, die op het eiland der Cyclopen was achtergebleven. Ovidius stelt het thans voor, alsof nabij Cumae een andere makker van Ulixes, Macareus, was achtergebleven. $\mathrm{Na}$ een verbaasde begroeting wisselen de beide kameraden hun belevenissen uit, waarbij Macareus het verhaal doet van Circe. Macareus en Achaemenides zijn, naar L a f a y e (Met. p. 127) opmerkt onder Ovidius' handen geworden tot twee legionairs, die op levendige wijze hun verhalen ten beste geven. Wij zullen nog gelegenheid hebben, hiervan enkele anwijzingen te geven.

Van groot belang voor de waardeering van Ovidius' versie van het Circeavontuur is, dat Ovidius het rechtstreeks aan Homerus heeft ontleend. Zijn veranderingen zijn dus welbewuste afwijkingen. Wij zullen eerst aantoonen, dat Ovidius de Homerische versie niet enkel tot in details kent, doch haar enkele keeren als het ware citeert. Daar zijn in de eerste plaats de tweeëntwintig ver-

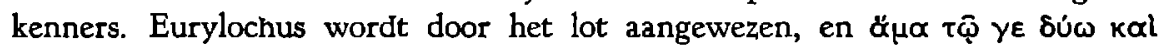

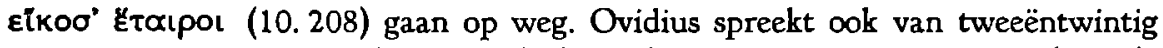
verkenners: Macareus, Polites, Eurylochus, Elpenor, bisque novem socios (251/3). Dat hij Eurylochus beschouwt als één der tweeëntwintig verkenners en niet als hun hoofdman en de drieëntwintigste, is een vergeeflijke vergissing. Degenen, die hij met name noemt, zijn zorgvuldig gekozen : Macareus, zijn eigen geestesproduct, behoort er uitteraard bij; de overige mannen zijn uit Homerus bekend : Polites wordt door Homerus onder de verkenners genoemd; Eurylochus is de man, die Ulixes over het lot zijner makkers zal inlichten; Elpenor wordt door Homerus

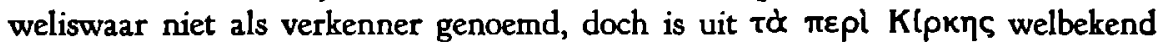
(552/60; in de onderwereld : $11.51 / 83$; begraven : $12.8 / 15)$. Andere verkenners, 
dan die bij Ovidius voorkomen, noemt Homerus niet met name. Een gedetailleerde kennis van Homerus verraadt Ovidius door het epitheton fidus, dat hij Polites geeft ; formeel herinnerend aan Vergilius' fidus Achates, is het niet cen willekeurig gekozen epische versvulling, doch een zinspeling op Homerus, bij wien

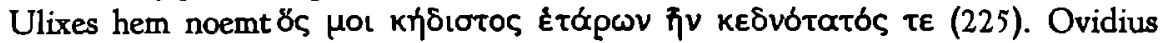
makt van deze overeenkomsten met Homerus gebruik, niet enkel om er mede te paradeeren, doch ook om een veristisch effect te bereiken. Door het noemen van enkele namen en door de toevoeging van kleine details roept de eene soldaat den anderen oude bekenden voor den geest. Het eene woord fidus is niet alleen voor den kenner van Homerus voldoende, doch ook voor den goeden verstaander Achaemenides. Twee woorden herinneren den kenner van Homerus aan de rol, die Elpenor speelt in de Odyssee, doch maken daarnaast van Elpenor, slachtoffer van wel een momentanen roes, een bekend alcoholist: nimioque Elpenora vino: Achaemenides weet er alles van. Er worden oude herinneringen opgehaald.

Van een minutieuze kennis van Homerus getuigt vervolgens de samenstelling van den welkomstdrank, dien Circe den verkenners reikt; Homerus

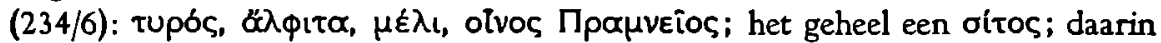

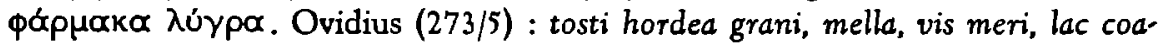
gula passum; het geheel een dulcedo ; daarin suci. Dit is formeel citeeren. Hetzelfde geldt van de verzen over het anti-tooverkruid, dat Mercurius aan

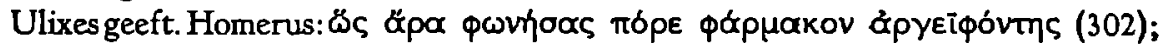

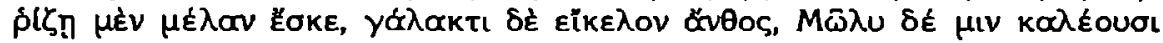
$\theta \varepsilon o l$ (304 v.). Ovidius (291 v.) : pacifer huic dederat florem Cyllenius album: Moly vocant superi, nigra radice tenetur. Ook in zijn woorden over Circe's dienaressen geeft Ovidius van een grondige kennis van Homerus' versie blijk ; hierover zal nog gesproken worden.

Daar zijn echter ook verschillen; zooals uit het bovenstaande blijkt, moeten het welbewuste afwijkingen zijn. De kwispelstaartende dieren rond Circe's paleis worden door Homerus gespecificeerd als wolven en leeuwen (212.218), door Ovidius als lupi, ursi en leae (255). Ovidius' specificatie staat wel onder invloed van die van Vergilius in Aeneis VII (leones, sues, ursi en lupi; 15/8). Sues worden door Vergilius vermeld als een verwijzing naar Ulixes' avontuur; voor Ovidius is er geen reden, deze dieren aan te houden. Ursi bij Vergilius worden wel verklaard hiermede, dat de opsomming gevarieerder werd en het gehuil, dat Aeneas en de zijnen op zee in de verte hooren, beklemmender. Lupi roepen verder in dit verband herinneringen op aan $\lambda u k \& v \theta p \omega \pi$ o (Verg. ecl. 8.97; Ov. 7. 271), uit de wereld der magie. Ovidius sluit zich bij zijn Romeinschen voorganger gaame aan, omdat ook hij Homerus' specificatie wel wat schamel gevonden zal hebben en omdat hij nimmer een zinspeling op zijn grooten voorganger versmaadt. Waarom leae i.p.v. leones? leaeque vormt een beter verseinde dan het hypermetrische leonesque; femininum metri causa. Misschien komt hier nog bij, dat de vrouwelijke exemplaren voor gevaarlijker golden (hetgeen men reeds in de Homerische vergelijkingen kan vinden ; de wijfjes worden — als ik het wel heb - sedert de alexandrijnsche dichters in de epische poëzie geprefereerd) en 
daardoor het contrast met haar makke vriendelijkheid rond Circe's paleis grooter werd. Dit evenwel is een kwestie, die niet rechtstreeks met de godenschildering samenhangt, hetgeen wel bij de thans volgende afwijkingen het geval is. Tusschen beide dichters is een groot verschil in de ontvangst der verkenners ten paleize van Circe. Homerus : Circe, die aan den weefstoel bezig was, zingend daarbij met schoone stem, komt zelf opendoen. Ovidius: door dienaressen ontvangen, worden de verkenners door een marmeren atrium in een schoone binnenzaal geleid, waar de meesteres ten troon zit. De verklaring van deze afwijking levert een beschouwing van de Homerische Circe en haar huis. Circe is bij Homerus een niet onaanzienlijke godin, die, haar afzondering in aanmer-

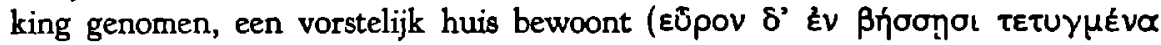

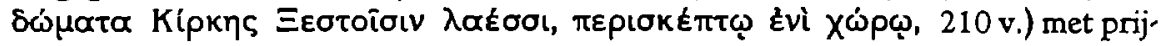
zenswaardig huisraad ( $352 \mathrm{vv}$.). Dit valt nog meer op bij een vergelijking met Calypso's wel romantischer, doch minder deftige grotwoning. Bij Calypso is er een knappend vuur, een geur van cederhout en wierook; Hermes ontvangt er weliswaar de gebruikelijke godenspijs en -drank, doch hij moet zich tevreden

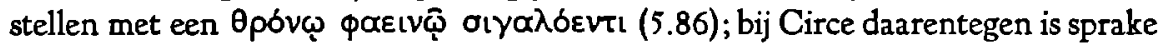

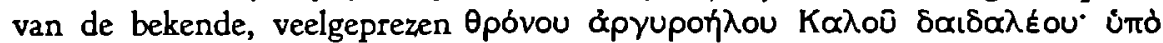

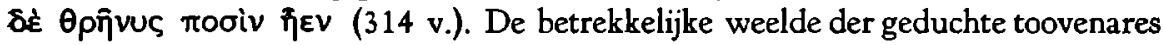
is den antieken lezer stellig niet ontgaan; terecht noemt Vergilius - die Circe's rijkdom contamineert met de romantiek bij Calypso (geurig cederhout, 7.13) haar dives en spreekt hij van haar tecta superba (12). Ovidius nu heeft de weelde van Circe op zijn eigen manier, naar de opvattingen van zijn tijd beschreven, zooals Homerus het op zijn manier, naar de opvattingen van zijn tijd gedaan had. Natuurlijk komt de voorname dame niet zelf open doen; natuurlijk komen de bezoekers eerst in het atrium, en dit is billijkerwijs marmore tecta (260). En zou de geduchte toovenares aan het weven, de machtige meesteres aan het zingen zijn? $\mathrm{Zij}_{\mathrm{ij}}$ ontvangt de vreemdelingen plechtig ten troon gezeten, en, volgens de laatste mode, smaakvol en kostbaar gekleed : in blinkend wit en goudbrocaat; de auratae vestes waren in Augustus' tijd zeer in zwang ( $\mathrm{E} \mathrm{h}$ w a l d ad 8. 448). Wij hebben hier dus te doen met een weloverwogen en consequente moderniseering; Ovidius teekent Circe als een Romeinsche dame ( $\mathrm{Ehw}$ ald ad 260); van archaische eenvoud is aan deze audiëntie verleenende koningin ( $\mathrm{L}$ a f a y e Met. p. 128) geen spoor meer.

De magie mocht zich zeer in de belangstelling van Ovidius' tijd verheugen. Dit is ook wel de reden, waarom Ovidius Homerus vertaalt in de passages over de samenstelling van den welkomstdrank en het anti-tooverkruid. Talrijk zijn de boutades op de hekserij bij de Augusteische dichters (Tibull. 1.2.41 vv.; 1. 8.17 vv. ; Propert. 1. 1.19 vv. ; 4. 5.9 vv. ; Ovid. A. 1. 8. 5 vv. ; 2.1 .23 vv. ; 3. 7.27 vv.; H. 6.83 vv.; Rem. Am. 249 vv.; Med. Fac. Fem. 35 vv.; Met. 7. 199 vv. ; Verg. ecl. 8.69 vv. e.a.). Circe en Medea hadden daarbij een spreekwoordelijke faam (bijv, quidquid habet Circe, quidquid Medea veneni, Tibull. 2. 4. 55). Het baart weinig verwondering, dat Ovidius, wiens flair voor het populaire groot was, in de Metamorphosen ook op dit altaar geofferd heeft. Medea kreeg de groote beurt in boek VII (vooral 179/278); in boek XIV vergast hij 
zijn lezers op een reeks exhibities der groottooveres Circe. In het verhaal van Glaucus schildert hij haar gruwzame bedrijven in felle kleuren; in dat van Ulixes schildert hij de godin meer in huiselijke ongeving (in haar laboratorium als het ware, zooals wij nog zullen zien) ; in dat van Picus en zijn gezellen gaat hij zich, om een climax te bereiken, te buiten aan een waar delirium van hekserij. In zijn schildering van Circe als de machtige der machtigen treedt Ovidius deels in de voetsporen van Homerus, deels gaat hij eigen wegen. Koningin der toovenaressen, heeft Circe een buitengewone hofhouding. Hebben de dienaressen elders haar pensum wol te verwerken, het is de taak van Circe's dames een pensum kruiden selecteeren :

gramina disponunt sparsosque sine ordine flores 266

secernunt calathis variasque coloribus herbas;

ipsa, quod hae faciunt, opus exigit, ipsa, quis usus

quove sit in folio, quae sit concordia mixtis.

novit et advertens pensas examinat herbas.

Aldus verplaatst de dichter ons in een soort laboratorium. Men wordt herinnerd aan de Erinyale apotheek (zie "Ino"). Alles, wat de godin doet of wat er in haar paleis geschiedt, is afgestemd op haar bedrijf. Zingende weven past haar niet; treft zij Picus in het woud, dan loopt zij daar niet te wandelen ter verpoozing : utque novas legeret fecundis collibus herbas (347). Haar dienaressen gaan niet op, zooals bij Homerus, in huishoudelijke bezigheden als het ordenen van zetels en tafels, of de zorg voor wijn en bad (352/9). Dat Ovidius haar werkzaamheden bij Homerus wel kende, blijkt uit andere details over haar, die op Homerus teruggaan. Homerus spreekt van vier dienaressen (349) ; bij Ovidius hoort Macareus het verhaal van Picus uit den mond van una 2uattuor e famulis (310 v.). Aan Circe's dienaressen wijdt Homerus eenige merkwaardige verzen:

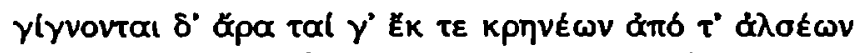

350

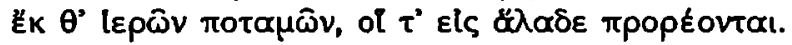

Merkwaardig is het praesens $\gamma(\gamma v o v t a l . ~ B l o c h$ (bij R o scher s.v. Nymphen Sp. 503) citeert met instemming Le hrs (Popul. Aufs. p. 95) : dit „elementare Entstehen" uit wouden, bronnen, rivieren etc. "soll jedenfalls etwas Besonderes sein, der Zaubersphäre entsprechend". Het is echter zeer begrijpelijk, dat Eustathius (ad Hom. p. 1660, 50), evenals $\mathrm{N}$ ä gel s b a ch en W el cker in moderne tijden (zie B $10 \mathrm{ch}$ ) haar als nymphen duidden. Ook Ovidius, die zelf sterk is in het vermelden van de verschillende soorten nymphen (zie „Salmacis”), vat haar ook op als de verschillende soorten nymphen van het land in tegenstelling tot de nymphen der zee. Hij spreekt van nymphae (264), doch voegt er in één adem bij Nereides. $Z_{i j}$ zijn wel bedoeld als een complement van de Homerische opsomming; zij maken het getal vier vol. Verder hoeft men voor een verklaring van Nereides wel niet te gaan; want het verband tusschen Circe en de zee is wel zeer los : het kan enkel dit zijn, dat zij, volgens Homerus (10.135) op een eiland woonde, volgens de Romeinen op het voorgebergte Circeji in Latium. Vitrea wordt zij genoemd door Horatius (c. 1. 17. 20) en Statius (silv. 1. 3. 85). He in ze

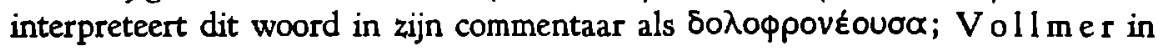


zijn commentaar op de Silvae vat het op als een aanduiding, dat zij als een watergodin beschouwd werd (wijl wonend op een eiland). Heinze ontkent echter, dat zij een watergodin is geweest. Circe hult zich 14.45 in caerule velamina; caerulus nu is de kleur van zee en Nereiden; caerulus is hier echter gekozen met het oog op de zee, niet de Nereiden : de toovenares gaat haar werk op zee verrichten, en onttrekt zich door camouflage aan ongewenschte blikken.

Wij spraken reeds over den welkomstdrank, waarbij Ovidius Homerus citeerde. Typeerend voor de Ovidiaansche godin is, dat zij den drank niet zelf bereidt, doch laat bereiden, om er tot slot zelf de tooveringrediënten aan toe te voegen; het slafelijk werk past de meesteres niet, de hekserij is daarentegen Circe's eigenlijk werk. Een ander eigen trekje van Ovidius, veristisch, typeert de arglistige: diffudit vultus (272). Verisme en ironie spelen dooreen in de opmerking, dat de verkenners den aangeboden drank gretig verzwelgen: quae simul arenti sitien-

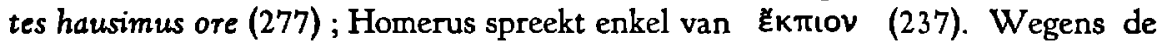
populariteit der magie werkt Ovidius vervolgens Homerus' eenvoudig ṕ́ $\beta \delta \omega$ $\pi \varepsilon \pi \lambda \eta \gamma \gamma u i \alpha(238)$ uit tot et tetigit summos virga dea dira capillos (278); hieraan is ook te wijten het tusschenzinnetje tantum medicamina possunt (285). Het sterkst echter blijkt de voorliefde voor de magie, als wij Homerus en Ovidius gaan vergelijken in de beschrijving van de handelingen, waardoor de zwijnen weer menschen worden. Homerus spreekt simpelweg van een $\phi \alpha p \mu \alpha \kappa o v ~ \& \lambda \lambda_{0}$ (392) ; de rite is bij Ovidius vrijwat ingewikkelder :

spargimur ignotae sucis melioribus herbae 299

percutimurque caput conversae verbere virgae verbaque dicuntur dictis contraria verbis.

Suci staat op gelijke lijn met фápuarov; de staf is ook wel aan Homerus ontleend (Circe gaat, zegt hij, met haar staf in de hand naar het kot); nieuw is, dat de virga conversa is ; en tenslotte vermeldt Ovidius extra de tooverformule. Carmen et herba zijn bij de Romeinsche dichters (bijv. Am. 3. 7. 28 ; M. 10.397; Tibull. 1. 8.17; Verg. georg. 3. 283), ook in boek XIV (bijv. 34 gramine cum tantum, tantum quoque carmine possim; 43 v. ; 55/8; 357; 403/5; vgl. nog ter iuvenem baculo tetigit, tria carmina dixit, 387), even onafscheidelijk als Castor en Pollux.

Tenslotte moet gesproken worden over Circe's wulpschheid. Horatius omschrijft haar als de domina meretrix (Ep. 1.2.25). De naam Circe was spreekwoordelijk voor ,verleidende deeme" (S e eliger bij R os cher s.v. Kirke Sp. 1197). Dit blijkt ook uit Ovidius' verhalen genoegzaam. $Z_{i j}$ is in puncto Veneris heetgebakerd; zij heeft geen last van rusticitas: ipsa rogat, zooals het in de Amores heet (1.8.44), en neemt het initiatief tegenover Glaucus en Picus; de dichter wijst erop en oppert een mythologische verklaring : neque enim habet aptius ulla Talibus ingenium, seu causa est huius in ipsa, Seu Venus indicio facit

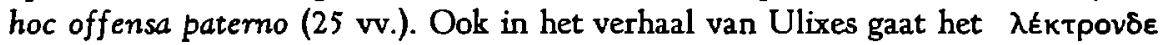
van haar uit; fijntjes spreekt Ovidius over Ulixes' bekende voorwaarde, de restauratie zijner makkers, als Ulixes' coniugii dotem (298) ; en een der geslaagdste verzen van Ovidius is, wat Macareus losjes zegt: cum duce namque meo 
Circe dum sola moratur (312) : men merke op, dat zij het onderwerp is, niet hyj. Dit eene vers schept sfeer door al de associaties, die de geraffineerd eenvoudige woorden opwekken. De soldaat kent het leven en zijn chef; it is the natural thing to do; ieder houdt op zijn tijd van a httle privacy

Ovidius heeft dus in dit verhaal Homerus als zijn direct voorbeeld gehad, de citaten laten daarover geen twijfel bestaan; weloverwogen zijn dus ook de afwijkingen. Hij moderniseert Circe, in haar paless, haar kleeding, haar optreden; hij schildert haar als de konıngin der toovenaressen, naar den smaak en de voorstellingen van zijn eigen $t_{1 j} d$, en als de heetgebakerde meretrix, niet zonder Irome. $\mathrm{H}_{\mathbf{1}}$ heeft Homerus' verhaal in alexandrijnschen geest omgewerkt, en wel zelfatandig, al moge hy in alexandrijnsche gedichten, die voor ons verloren gegaan zijn, reeds suggesties gevonden hebben in de nchting van hetzi] modern1seering of vermenschelijking, hetzij uitbreiding van haar hekseri]

\section{AENEAE NAVES (XIV 530-559)}

Het verhaal van de verandering van Aeneas' schepen in nymphen door het Ingrupen der Godenmoeder komt eerst bij Vergilius voor (9.69 vv) Tusschen Vergilius en Ovidius liggen wel geen andere bewerkingen Daar dus de mogelijkheid van inwerking door vananten van andere schnjvers of een mythologisch compendium urtgesloten is, is dit verhaal voor een onderzoek naar Ovidius' zelfstandigheid tegenover zijn voorbeelden van het grootste belang. De kwestie der Ovidiaansche godenschildenng geeft gereede aanleiding tot een bestudeering der beide versies.

$B_{1 j}$ Ovidius heeft het voorval plaats nà, bij Vergılıus vóór den terugkeer van Venulus, den gezant naar Diomedes. Vergllus laat Venulus eerst terugkeeren na deze en andere gebeurtenissen, en wel op het moment, dat Diomedes' afwijzende houding de verslagen Italiers van hun laatste hoop berooft, zoodat herop dan ook Latınus voorstelt vredesonderhandelingen aan te knoopen (11.225 vv.). Zoo wordt het volle profijt getrokken uit dit mislukte gezantschap. Ovidius echter, die geen verhaal van Aeneas' strijd componeert, doch de Aeneis slechts benut als een leiddraad voor zijn verhalenkrans, werd niet door compositioneele overwegingen gedwongen tot dislocatie van den terugkeer van het gezantschap. Aan den anderen kant zou een slaafsch volgen van de chronologie der Aeneis hem in een ondergeschikt punt genoopt hebben tot herhalingen, die ongewenscht waren. Daarom werkt hij eerst Venulus' gezantschap af, alvorens van Aeneas' schepen te vertellen. Anders zun doel en muddelen der Aene1s, anders die der Metamorphosen.

$B_{1 j}$ Ovidius zijn de schepen door het vuur aangetast. Is dit ook bij Vergilius het geval ? Neen, want : Turnus, spoedig gevolgd door de gansche schare, grujpt een fakkel, men plundert de altaarhaarden, zwarte rook en dwarrelende asch stijgen op en onttrekken de bedreigde schepen aan onze oogen; terwijl wij ons met angst en vreeze afvragen, wat er van de schepen worden zal (de fantasie werkt op eigen kracht verder), breekt het verhaal af, en volgt een statig verslag van een statig onderhoud in den hemel tusschen Cybele en Juppiter uit lang vervlogen dagen, ver van het aardsch stnjdgewoel : voortreffelyjk contrast. Als 
het verhaal weer wordt opgenomen, beveelt de godin haar schepen de banden te verbreken en vrij uit te gaan, nymphen der zee; en zoo geschiedt het. Ofschoon dus de schepen niet gebrand hebben, voelen wij, door Vergilius' kunst, dat zij aan den uitersten rand der vernietiging geweest zijn. Vergilius beschrijft wel in boek V een scheepsbrand; in boek IX zegt hij echter niet, dat de schepen gebrand hebben. Thans vrijwaart de godenmoeder haar beschermelingen; herhaling schaadt. Ovidius echter contamineert, zonder gevaar voor monotonie, de episode uit Aeneis IX met die uit Aeneis V (622 v. 680 vv.), en de brand is een opwindend moment.

In de schildering van den brand en het blusschen zijn er tusschen beide dichters opmerkelijke verschillen. Bij Vergilius wordt (een doodelijk gevaar) de romp aangetast ; het sombere schouwspel wordt intens en suggestief beschreven : trage rookwolken kruipen als sluipmoordenaars uit de hennep onder langs het natte hout omhoog; als Aeneas arriveert, heeft het vuur zich uitgebreid en woedt over de roeibanken, riemen en het achterschip. De aanvankelijke traagheid vergroot het gevoel der fatale onafwendbaarheid, waartegen alle menschelijke krachten falen. Bij Ovidius daarentegen gaat alles vliegensvlug in zijn werk : in een oogwenk staan het pek en de was tusschen de voegen en al wat voor de vlammen een gretig voedsel is, in lichterlaaie; langs den mastboom springt het vuur de zeilen in ; vitale deelen staan bij hem niet in brand; het gaat snel, doch niet intens, het is meer vlam dan vuur, en spreekt meer de fantasie dan het gemoed aan.

Volgt het ingrijpen van Cybele. Vergilius : een ongewoon licht glanst op, een geweldige wolk doorloopt den hemel van uit het Oosten (Phrygië); Idaeische koren; dan schalt een huiveringwekkende stem door de lucht : beeld van verheven mysterie, in woorden vervat, waarin de religieuze huiver trilt. Al hooren wij de stem, de godin zelf zien wij niet; deze blijft achter de goddelijke wolk voor ons oog verborgen. Ovidius : cymbalen dreunen, fluiten snerpen, tenslotte verschijnt de godin zelve op haar wagen, door leeuwen getrokken. Men denkt, evenals in boek IX in de verzen over Isis, onwillekeurig aan een processie, die bont en larmoyant door Rome's straten trekt. (Voor larmoyante kleurrijke optochten zie: 3.532 v.; 4.4 vv.; Ars 1.537 vv.; F. 3.737 vv.; 11.16 vv.; de optocht van Cybele: Fast. 4.181 vv.; de godin op haar wagen is naar de mythologie, in den optocht te Rome werd het beeld op de schouders van haar dienaren gedragen, 185). Van Vergilius' terughoudendheid en ontzag geen spoor; Ovidius geeft een show. Opmerkelijk is ook het volgende : bij Vergilius richt zich de stem tot de Trojanen, over Turnus wordt slechts in den derden persoon gesproken, hetgeen de goddelijke majesteit zeer ten goede komt en Turnus' kleinheid voortreffelijk doet uitkomen; daarna richt de stem zich rechtstreeks tot de schepen met het bevrijdende woord. Bij Ovidius wendt de godin zich tot Turnus; geen afstand of waardig dédain, enkel pompeuze woorden; ook wordt niet tot de schepen het verlossende woord gesproken. De verklaring hiervoor ligt in Aeneis V. Daar richt zich Aeneas in een bezwerend gebed tot Juppiter. Nauwelijks heeft hij zijn gebed geëindigd, of een geweldige ontlading der natuurelementen volgt : regens stroo men neer, zwarte storm woedt onbedaarlijk, donder doet de toppen der aarde 
en de velden sidderen, in dichte buren ontlaadt zich een slagregen, die de aangetaste stevens overstelpt. Ovidius : terwill de godın nog spreekt (nog sneller dan in de Aene1s), dondert het reeds, regen plenst neer, hagelsteenen kletteren en dansen rond Dit alles wordt kort afgedaan; volgt, dat de woedende winden in onderlingen strud hemel en aarde door hun plots geweld beroeren Het 1s, alsof Ovidius de Vergiliaansche beschrijving aan wil vullen met een beeld der worstelende winden, ut de epische vergelıkingen welbekend Deze amplificatie blykt dan echter in de ontknooping een belangnjk moment $B_{1 j}$ Vergilius wil de stem, dat de schepen de banden verbreken en vrjuit gaan, nymphen der zee, en zil worden nymphen der zee, hun banden verbrekend en onderdukend in zee. $B_{1 j}$ Ovidius slaat een der winden de kabels los, druft de schepen de holle baren op en brengt ze daar tot zinken Het is een verrassend slot, dat, in alexandrijnschen trant (vgl He um a n $\mathrm{p}$ 47) het wonderbaarlyke bijna weg-rationaliseert. $B_{1 j}$ de beschrjving der metamorphose, voor de Metamorphosen van belang, trekt Ovidius met zichtbaar genoegen een ingenieuze parallel tusschen de scheeps- en de lichaamsdeelen, waarbı hu net nalaat te vermelden, dat de bulk de buk blyft en de kleur van schip zoowel als nymph blauw is De episode eindigt met eenige gezochte antitheses.

$B_{1 j}$ Vergllus vinden wij dus terughoudendhe1d en heilig ontzag, bij Ovidius weeldenge beschrijving en ingeniositeit. $B_{1 j}$ den eerste is de godin onzichtbaar, doch haar macht des te sterker $B_{1 j}$ den tweede is de godin en haar woord pompeus, doch het verband tusschen haar woorden en het wonder is zeer los. De hemelsche stoet, door Vergilus gesuggereerd, wordt een interessante, bonte optocht Het goddelyjk machtswoord gaat verloren in het gebulder van den storm Ovidius' verklanng voor het verdwinnen der schepen in de diepte zweemt naar Euhemerisme; zoo zou een nuchter atheist het wonderlyk feit kunnen verklaren Het verband tusschen de godin en den storm is niet erg nadrukkelıjk, en zoo de redding, vooral als men Vergilius voor oogen heeft, ingenieus 1s, indrukwekkend is ze niet Ovidius ziet nuet slechts kans twee episodes van Vergilius te contamineeren, doch ook bij de ontknooping eigen wegen te gaan, en de sfeer volkomen te veranderen. Het is, of Ovidius bij maxumale overeenkomsten maxumale verschillen wilde bereiken, om zoo aan een volkomen eigen episode der Romeinsche litteratuur zelfstandig de alexandnjnsche ingeniositert te vertoonen A Rohde ( $p$ 37), beide episodes vergelykend, beweert, dat Ovidius met Vergilius wil wedijveren, ten onrechte, want beide dichters werken op een geheel ander nuveau; Ovidius wil geen verbetenng, doch een contrast; aan de eene zide staat de coryphee der verheven Romeinsche poezie, aan de andere zujde de coryphee der moderne richting, eerbiedig, doch zelfbewust: laudamus veteres, sed nostns uttmur annis.

\section{AENEAE APOTHEOSIS (XIV 581-608)}

De vereering van Aeneas Indiges lag Augustus om begrijpelijke redenen na aan het hart Het plan der Aene1s vergunde Vergilius net de apotheose van den held hierin te beschrijven: hij anticipeerde deze evenwel in Juppiter's 
woorden tot Juno in boek XII : Indigetem Aenean scis ipsa et scire fateris Deben caelo fatisque ad sidera tolli (794 v.). Daar de apotheose als een metamorphose kon worden opgevat, greep Ovidius de gelegenheid aan on dat te beschrijven, waarnaar Vergilius slechts had kunnen verwijzen. Snel wordt de tijd tusschen Turnus' dood en Aeneas' vergoddelijking afgedaan ; vervolgens worden beknopt de twee voorwaarden genoemd, die Aeneas' apotheose mogelijk maakten : Juno en de overige (vijandig gezinde) goden zijn door Aeneas' virtus gewonnen, en de heerschappij van Julus is hecht gefundeerd. Wat het eerste betreft, hier veroorlooft zich de dichter, terecht, een lichte afwijking van Vergilius, bij wien Juno eerst op manen van Juppiter van haar wreede vervolging afziet; dit geschiedt nog vóór den val van Turnus; Vergilius anticipeerde deze verzoening, omdat de val van Turnus het besluit zou zijn van de Aeneis. Niet door compositioneele overwegingen genoopt, verkoos Ovidius de natuurlijke ontwikkeling der gevoelens; want de vreugde, die er in haar hart 1s, volgens Vergilius, na Juppiter's toezegging, dat de naam Troje voor den Latijnschen naam plaats zal maken en dat een bijzondere pietas het nieuwe volk zal kenmerken ( $839 \mathrm{v}$.), is niet geheel overtuigend bij een felle persoonlijke vrouw als Juno; bij Ovidius geen chèque op de toekomst, doch de feiten, die het bewijzen. Ovidius sluit zich echter nauw aan bij de gedachtenwereld der Aeneis door Juno te laten bekeeren door de Aeneia virtus, die natuurlijk is de befaamde pietas Aeneia (Fast. 4. 799). Ook in het vermelden der tweede voorwaarde toont Ovidius zijn bekendheid met de gedachtenwereld der Aeneis ; want de zorg voor Julus is bij Vergilius een van Aeneas' kenmerkendste eigenschappen. Zoo is bij zijn besluit om Carthago te verlaten zijn voornaamste overweging, dat hij anders Ascanius onrecht zou aandoen (4. 234 ; 274 vv. ; 354 v.). Verstandig doet ook Magus, die, smeekend om lijfsbehoud, Aeneas bezweert per patrios manis et spes surgentis Iuli, waarop de held bitter, doch niet ongeroerd repliceert met hoc patris Anchisae manes, hoc sentit Iulus $(10.524,534)$. Julus is de magnae spes altera Romae (12.168), stamvader van het Julisch geslacht. Ook formeel herinnert Ovidius aan Vergilius : crescentis Iuli (583) naar surgentis Iuli (6.364; 10.524; vgl. Ascanium surgentem et spes heredis Iuli, 4. 274); crescentis, wijl sedert Turnus' val de knaap een aankomend man is geworden. Ovidius betoont zich dus een goed kenner der Vergiliaansche gedachtenwereld; hij verwijst naar den verheerlijker van Rome in het Julisch geslacht; hij doet officieel; het is een officieel onderwerp. Het officieel karakter dezer episode blijkt ook sterk aan het eind van het verhaal. Ovidius spreekt met eenige uitvoerigheid over Aeneas' dood en verheerlijking; dit rechtvaardigt de opname der episode in de Metamorphosen. Hij kleedt echter Aeneas' dood, om officieele redenen (anders zou hij er een gewoon verdrinkingsgeval van gemaakt hebben), op diplomatieke wijze in : het is geen jammerlijk toeval : de Numicius wascht, op hooger bevel, af, wat aan den dood onderdanig is; hij reinigt Aeneas van het sterfelijke in hem: quaecumque obnoxia morti, Abluere (600 v.); quidquid in Aenea fuerat mortale, repurgat (603). De termen zijn even diplomatiek als bij de apotheose van Hercules. Venus verricht verder persoonlijk de laatste handelingen. Het hoofsch karakter van dit verhaal blijkt tenslotte in de slotverzen: quem turba Quirini Nuncupat Indigetem temploque arisque recepit (607 v.). 
Aeneas' apotheose is dus niet alleen in feite een officieel onderwerp, Ovidius is er ook van doordrongen, weet wat van hem verlangd wordt en aan wien hij zich moet spiegelen. Dit werpt een merkwaardig licht op de merkwaardige schil. dering van Venus en Juppiter in dit verhaal. De apotheose wordt aangevraagd en toegestaan in een godenraad; dit blijkt uit de aanwezigheid der goden (592). Om het verhaal niet te remmen spreekt de dichter niet over de convocatie ervan, sedert hij dit grondig heeft gedaan in Bk. I. Eerst heeft Venus reeds stemming gemaakt onder de goden voor haar candidaat; de dichter spreekt van ambire (585; hoe zij dat doet, wordt in „Caesaris apotheosis" verteld) : het herinnert ons aan Rome (B e ck p. 41 : quo loco verbo ambeundi morem Romanum, quo quicum. que munus petivit, cives suos singulos adiit et oravit, ut sibi in comitiis faverent ac se crearent. Idem facit Venus loco laudato per deos ambiens). Nu wendt zij zich tot Juppiter. $Z_{i j}$ houdt evenwel geen groote rede, doch slaat de armen om vaders hals, en vleit en trekt een pruillipje. $Z_{i j}$ vraagt om zijn heel speciale gunst ditmaal. Het betreft ,haar' Aeneas, zijn kleinzoon, een numen voor hem, hoe klein ook, als hij maar iets krijgt (dummodo des aliquod, 590). $\mathrm{Z}_{\mathrm{ij}}$ vraagt het als een persoonlijke gunst voor zichzelve, niet met een beroep op 's mans virtus of pietas of omdat hij de stamvader is van wereldbestierders. Indien zij al verwijst naar zijn tocht naar de onderwereld, dan is het niet om op zijn pietas te wijzen, doch om er een gevoelerig argument uit te slaan, dat hij toch niet een tweede maal daarheen behoeft te gaan. Niets dan eerzucht drijft, zou men zeggen, Venus tot haar verzoek. Zwakker had het verzoek om apotheose niet gerechtvaardigd kunnen worden. Juppiter spreekt in zijn antwoord even van Aeneas' verdiensten, doch, terwijl hier eigenlijk de nadruk op moest vallen, slechts terloops, en in zulk een verband, dat het compliment eigenlijk voor Venus zelf bedoeld is : ,estis' ait ,caelesti numine digni, 2uaeque petis pro quoque petis' (594 v.). Juppiter staat Venus de apotheose toe, als een almachtige papa, die zijn dochter niets kan weigeren (,numquam mihi' dixerat, ullo Tempore dure pater, nune sis mitissimus, opto', 586 v.). De pater (594) geeft zijn nata haar zin (quod optas). Hij richt zich tot haar persoonlijk, als in een gesprek. De plechtige toezegging is van alle plechtigheid ontdaan. Fatus erat heet het, omdat een groote beslissing is gevallen; doch het lijkt wel, of een vorst de troonrede afsteekt in huisjas. Wil men het verschil merken met de officieele voorstelling van zaken in zulk een aangelegenheid, dan vergelijke men de apotheoses van Hercules en van Romulus; met die van Aeneas komt de apotheose van Caesar overeen.

Wij zien dus, dat Ovidius' goden ook in zaken van wereldhistorische importantie, in een stuk officieele epiek geschilderd worden als particuliere personen en familieleden, niet als de wereldbestierders met oog voor de groote lijnen; hun is eerder alle goddelijks vreemd dan iets menschelijks. Onkunde is uitgesloten, zooals uit de officieele noten in dit verhaal blijkt; onmacht eveneens, zooals andere soortgelijke verhalen bewijzen; Ovidius vermenschelijkt de goden wetens en willens. Hij doet dit op eigen gezag ; geen beroep op een ,slecht voorbeeld' is hier mogelijk. Het onderwerp leende zich meer voor een statige, officieele behandeling dan voor vermenschelijking. Ovidius echter leende zich niet dan voor de moderne manier. 


\section{POMONA (XIV 623-771)}

Onder "Salmacis” werd reeds opgemerkt, hoeveel genoegen Ovidius heeft in de beschrijving of ook slechts de loutere vermelding van de luchtige halfgoden des velds en de nymphen, met hoeveel voldoening hij hun aanwezigheid ook op Italischen bodem vermeldt. Canens wordt een nymph, schoon en vocaal begaafd; Picus, equum domitor (Verg. 7. 189), wordt tot een knappe chevalier (14. $320 \mathrm{vv}$.), afgod van alle nymphen. $\mathrm{Z}_{\mathrm{j}}$ worden alexandrijnsch bewerkt; het is geen toeval, dat het beeld van Picus bij Vergilius, naar den eenvoud der oude tijden,vervaardigd is uit hout (antiqua e cedro, 7.178), bij Ovidius daarentegen, naar de luxe van den nieuweren tijd, uit marmor (niveo factum de marmore, 313). De lichtende voorbeelden echter van de moderne interpretatie der oude Italische godheden zijn onder Ovidius' handen geworden Pomona en Vertumnus. Deze, weliswaar wezensverwant, doch, voorzoover ons bekend, noch mythologisch noch sacraal met elkaar verbonden, zijn eerst door Ovidius in een liefdesverhaal samengebracht, dat, analoog gevormd naar talrijke soortgelijke verhalen, een alexandrijnsch-idyllisch karakter draagt ( $\mathrm{h} h$ wald ad 623). Naar Wi s owa (R.S. p. 163 en 166 v.) heeft uiteengezet, streeft Ovidius zoo hier als elders ernaar, om Grieksche sagen te stoffeeren met Romeinsch godenpersoneel, waarbij hij, om tot een iets rijker beeld en een breedere uitwerking van het thema te geraken dan de Romeinsche mythologie hem bood, verschillende namen combineerde en eigenmachtig intrigues verzon. Dit is een belangrijke innovatie, doch overigens onthoudt Ovidius zich van „originaliteit"; hij is erop bedacht, slechts bekende motieven te verwerken. $E_{r}$ is in ons verhaal nagenoeg niet één enkel detail, waarvoor geen parallellen aan te halen zijn uit andere verhalen van Ovidius of van andere dichters. De verklaring hiervan zal aan het slot gegeven worden.

Eerst wordt Pomona geteekend, en wel, zooals haar naam te verstaan geeft (unde tenet nomen, 626), als tuinierster. De dichter heeft zich echter geinspireerd op het type van de preutsche jageres (Daphne, Syrinx etc.); haar naam en werkzaamheden verhinderden een volledige gelijkschakeling, doch niet het trekken van een parallel :

non silvas illa nec amnes, 626

rus amat et ramos felicia poma ferentes;

nec iaculo gravis est, sed adunca dextra falce etc.

Met de jageressen heeft zij gemeen, dat zij wars is van de liefde : hic amor, hoc studium. Veneris quoque nulla cupido (634; de eerste vershelft is ontleend aan Vergilius 11.739, waar echter heftig uitgevaren wordt tegen de wulpschheid der Etruriërs, die, in tegenstelling tot Pomona, non in Venerem segnes nocturnaque bella, 736, zijn). En zooals de jageressen, is ook Pomona een begeerde buit der wulpsche goden des velds :

quid non et Satyri, saltatibus apta iuventus, 637

fecere et pinu praecincti cornua Panes

Silenusque suis semper iuvenilior annis, quique deus fures vel falce vel inguine terret, ut poterentur ea? 
Men kan hiermede vergelijken uit „Syrinx":

non semel et Satyros eluserat illa sequentes 1.692

et quoscumque deos umbrosaque silva feraxque

rus habet etc.

en wat Oenone zegt (Her. 5.135 vv.):

me Satyri celeres (silvis ego tecta latebam)

quaesierunt rapido, turba proterva, pede

cornigerumque caput pinu praecinctus acuta

Faunus in inmensis, qua tumet Ida, iugis.

Van dezelfde wulpsche goden des velds vinden wij in Fasti I (397/400 en 411/16), in het verhaal van Lotis, een even ondeugende opsomming als hier. Ovidius werkte gelijktijdig aan Metamorphosen en Fasti ; uit een vergelijking blijkt, dat hij de fijne pointes in „Pomona” aan "Lotis” ontleend heeft :

F. 397 in Venerem satyrorum prona iuventus.

Met. Satyri, saltatibus apta iuventus.

F. 412 tibi, qui pinu tempora nexa geris.

Met. pinu praecincti comua Panes.

F. 413 te quoque, inexstinctae Silene libidinis, urunt : nequitia est, quae te non sinit esse senem.

Met. Silenusque suis semper iuvenilior annis.

F. 400 quique ruber pavidas inguine terret aves.

Met. quique deus fures vel falce vel inguine terret.

Het motief der begeerige goden des velds heeft Ovidius dus voor zijn preutsche tuinierster overgenomen uit de alexandrijnsche verhalen van preutsche jageressen; terwijl hij voor de dartele uitwerking ervan te rade ging bij een eigen verhaal. - Zooals nu de jageressen zich in de bosschen verbergen, sluit Pomona haar gaarde. (Kleinere overeenkomsten met vroegere verhalen vinden wij o.a. in de opening van het verhaal : qua nulla Latinas Inter hamadryadas coluit sollertius hortos, 623 v. Inter hamadryadas vinden wij ook aan den aanvang van „Syrinx", 1.690, en van "Callisto", F. 2. 155. Voor nulla sollertius vergelijk uit den aanvang van "Arethusa", 5.578, nec me studiosius altera.)

Pomona's onhandelbaarheid en de matelooze begeerlijkheid van het godenvolkje leiden op gelukkige wijze het optreden in van Vertumnus, die hen allen in liefde overtrof zonder nochtans meer succes te hebben. Vertumnus buit zijn gave van vermomming, uit in allerhande pogingen om tot de schoone door te dringen. Achtereenvolgens probeert hij het als : oogster, maaier, ploeger, wijngaardenier, vruchtenplukker, soldaat, visscher. Zondert men de laatste twee uit, dan zijn al deze vermommingen geschikt om met de weerbarstige tuinierster contact te krijgen. Nu had reeds Propertius, in zijn bekende Vertumnuselegie (4. 2. 23/46; niet genoemd zijn ploeger en wijngaardenier, daarentegen vele andere wel), de meeste dezer vermommingen opgesomd. Ovidius verwijst naar Propertius : beiden spreken van messor en corbis (643 v. : 28), van hooi om de slapen en gemaaid gras ( 645 v. : 25 v.) ; falce data is het antwoord op da falcem 
(649:25); harundine sumpta is letterlijk ontleend (651:33). Ovidius wil dus wel naar Propertius verwijzen, en de reden is niet slechts, dat het heerlijk is ook naar Romeinsche dichters, en niet enkel naar Grieksche, te kunnen verwijzen, doch bovendien een verhooging der ironie der situatie; want bij Ovidius neemt Vertumnus in radelooze min vruchteloos zijn toevlucht tot dat, waarover hij bij Propertius glorieert.

„Soldaat" en "visscher" vallen uit den toon, omdat Vertumnus in deze ver. mommingen zeker geen kans heeft om tot de tuinierster door te dringen. Waarom heeft de dichter, ofschoon hij tevoren een selectie had ondernomen, aangepast aan de bijzondere omstandigheden der situatie (aan de agriculturale voorbeelden van Propertius voegde hij den ploeger en den wijngaardenier toe, twee vermommingen, die met het oog op Pomona's werkzaamheden dienstig konden zijn), toch ook deze twee vermeld? Misschien heeft hij willen suggereeren, dat Vertumnus ten einde raad zelfs het onmogelijke wilde probeeren. Doch de verklaring ligt wel vooral in het kunstig karakter der opsomming (op het kunstig karakter der opsomming wees reeds Peters p. 80). Want door aan de eerste drie gedaanten telkens twee verzen te wijden, aan de volgende twee telkens één vers, aan de laatste twee telkens een half vers, terwijl twee verzen het besluit vormen $(2+2+2+1+1+1 / 2+1 / 2+2)$, door dus aan de opsomming een eenparig versnelde beweging te geven, suggereert de dichter voortreffelijk, welke eindelooze pogingen de hardnekkige Vertumnus steeds weer blijft doen. Aangezien echter na de vijf eerste gevallen de agriculturale mogelijkheden uitgeput waren, terwijl er toch tot bekroning van het effect der opsomming nog snel twee vermommingen moesten volgen, voegde de dichter er den soldaat en den visscher aan toe, die hij weer aan Propertius ontleende $(27,37)$. Niet enkel de minnaar, ook zijn dichter is ten einde raad. De opsomming heeft, bij „soldaat" en "visscher" aanbeland, zulk een lawine-achtig karakter gekregen, dat de lezer weinig gelegenheid heeft om zich te bezinnen op de mindere geschiktheid der laatste twee voorbeelden.

Wij vinden echter in deze passage niet enkel een Propertiaansch element, doch ook, als mijn gevoel mij niet bedriegt, een element, dat ik Tibulliaansch zou willen noemen, dat er eerst haar ware bekoring aan geeft, doch dat moeilijk in woorden te vangen is. Ik bedoel het volgende : Ovidius' ironie is meestal een kwestie van esprit en epigrammatisch, verblindende bergtoppen ; Tibullus' verzen, niet minder van ironie doordrenkt, hebben echter meer hart en mildheid, lieflijke alpenweiden. Nu wil het mij voorkomen, dat de ironie van onze passage meer Tibulliaansch is dan typisch Ovidiaansch. De opsomming is levendig ingekleed: o quotiens - saepe - saepe (643 vv.) ; het schijnt een alexandrijnsche kunstgreep te zijn; het zou te ver voeren, alle passages te citeeren, waar de Romeinsche dichters van deze en dergelijke wendingen gebruik maken; ik wil hier slechts

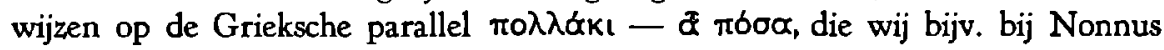
vinden in een passage over Apollo en Daphne (15.307 vv.). Wij vinden echter in Ovidius' passage over minnaar Vertumnus en Tibullus' passage over minnaar Apollo denzelfden toon en dezelfde wendingen: 
Ovidius : o quotiens habitu duri messoris aristas 643

corbe tulit verique fuit messoris imago.

tempora saepe gerens faeno religata recenti

desectum poterat gramen versasse videri.

saepe manu stimulos rigida portabat, ut illum

iurares fessos modo disiunxisse iuvencos etc.

(de verzen doen sterk distichisch aan)

Tibullus: o quotiens illo vitulum gestante per agros 2.3.19 dicitur occurrens erubuisse soror.

o quotiens ausae, caneret dum valle sub alta,

rumpere mugitu carmina docta boves, - -

saepe horrere sacros doluit Latona capillos etc.

Bij Propertius hebben wendingen als quis neget (24), iurabis (26), laudabar (27), clamabis (30) meer tot doel de lange opsomming leven en variatie te geven dan er een ironischen glans over uit te spreiden, en zijn daarom met verique etc., poterat, iurares niet geheel te vergelijken. Poterat versasse videri doet Tibulliaansch aan, daar deze dichter graag met posse opereert (bijv. 1.2. 20; 64; $1.6 .12 ; 1.8 .56)$, al is het waar, dat hij hierin niet alleen staat. Ook in duri (messoris) en rigida (manu) meen ik Tibulliaansche gevoelswaarden te moeten zien; dat Tibullus soms glimlacht over zijn delicaatheid temidden van agriculturale ontboezemingen, is onder "Hyacinthus" vermeld. Het is een zeer subtiele kwestie, en waarin men gemakkelijk het slachtoffer wordt van litteraire fata morgana; doch deze en dergelijke kleinigheden, gevoegd bij het weinig Ovidiaansche, niet epigrammatische karakter der ironie, die meer glanzend is dan flikkerend, maken, dat ik geloof, dat de vormgeving algemeen alexandrijnsch is, doch de sfeer Tibulliaansch. Ovidius is hier op zijn best, waar hij virtuositeit (het opnemen van motieven van Propertius, op een fraaie wijze geordend, in een nieuw verband) paart aan zuivere artisticiteit, en zijn esprit kan uitleven, zonder dat dit gaat ten koste van het gevoel.

In de gedaante eener oude bes gelukt het Vertumnus eindelijk tot de liefste door te dringen. Dat de goden zich vermommen om tot hun lief te geraken, is uit tallooze liefdesverhalen bekend. Een geliefkoosde vermomming is die eener oude vrouw, die o.m. Sol in "Leucothoë" en Apollo in "Chione" aannemen (4. $219 ; 11.310$; vergelijk verder Juno, 3. 275, Pallas, 6. 26, Ceres, Fast. 4. 517). Ovidius maakt hier dus gebruik van een bekend motief, dat echter zeer toepas selijk is : verboden toegang voor mannen. In de beschrijving der oude vrouw geeft Ovidius de gebruikelijke details (als anilia instrumenta, 766 v., worden genoemd mitra, baculum, cani sc. capilli, 654 v.; vgl. 3.275 vv.; 6.26 v.; 8.693 ; Fast. 3.669 v.). De comedie der vergissingen en dubbelzinnigheden prikkelt ook hier, zooals steeds (vergelijk bijv. Leucothoë"), Ovidius' ironie. Tanto potentior (657) zegt het complimenteuze oudje, doch tevens de verrukte minnaar. De kussen, die hij haar geeft, qualia númquam Véra dedisset anus (658 v.), herinneren aan die van Juppiter-Diana in "Callisto", nec moderata satis nec sic a virgine danda (2.431). Er wordt prachtig comedie gespeeld 
(L a f a ye Met. p. 233 spreekt van een mime) : pomaque mirata est (657); glaebaque incurva resedit Suspiciens pandos autumni pondere ramos (659 v.). Uitgangspunt voor het pleidooi, dat Vertumnus als zijn eigen koppelaarster ( $L$ a f a y e p. 232) voor zichzelf houdt, leveren de olm en de wijnranken, op. klimmend langs den olm. De situatie schijnt het vanzelf in te geven, en toch is het tevens een bekend motief uit de erotische poëzie (Catull. 61. 106/9;62.49/58 en $\mathrm{K}$ roll t.p.; zie verder Ovidius zelf : ulmus amat vitem, vitis non deserit ulmum : Separor a domina cur ego saepe mea?, Am. 2. 16. 41 v. ; Her. 5.47 v.), dat de dichter zeer gevat naar zijn hand zet. Het onuitputtelijk genoegen, dat Ovidius telkens weer blijkt te hebben aan dubbelzinnigheden, treedt ook hier weer aan het licht: quae te plus omnibus illis, Plus quam credis amo (676 v.); pro quo $\mathrm{Me}$ quoque pignus habes: neque enim sibi notior ille est, Quam mihi (678 vv.) ; miserere ardentis et ipsum, Quod petit ore meo, praesentem crede precari (691 v.).

Het slot is verrassend. Het pleidooi heeft geen succes; rest dus, als laatste middel, geweld, het geweld, dat uit de godenverhalen maar al te bekend is. Dan heet het echter plotseling : sed vi non est opus (770). Want, als Vertumnus zijn vermomming aflegt en zich in volle heerlijkheid openbaart, geeft Pomona zich, hierdoor betooverd, gewonnen. Zoo geeft zich ook Leucothoe gewonnen, als Sol zich in zijn waren glans en gewone schittering vertoont, en laat hem zonder klagen begaan (4. 231 vv.). De vergelijking, die Vertumnus' schoonheid illustreert, herinnert aan de vergelijking, waarmede de "Roof van Proserpina" besluit (5. 570 v.). Ha r tma n (p. 56) stelde de vraag : waarom de vermommingen, als Vertumnus' ware gestalte de weerbarstige betoovert? en geeft als verklaring, dat Ovidius geen geschikte ontknooping kan vinden voor zijn eigen intrigue en er zich met een Franschen slag van afmaakt. Het is waarschijnlijk, doch niet dwingend. Het moment der ironie, sterk in heel het verhaal, moeten wij hier niet uitschakelen : achteraf blijkt, dat alle manoeuvres overbodig waren, een lachwekkende ontdekking, nadat de minnaar, haar preutschheid en zijn eigen handigheid kennende, met omwegen begon, het slachtoffer van zijn eigen geraffineerdheid. Aldus laat zich dit verrassend slot verdedigen, en Ovidius zou zich stellig bij deze verklaring aansluiten, - ik vrees echter, a posteriori. In mijn hart ben ik het met $\mathrm{Hartman}$ eens, doch hiermede geraken wij op terreinen, waar argumentatie en wetenschap ophouden.

Het verhaal van het Latijnsche paar Pomona en Vertumnus is dus een eigen vinding van Ovidius. Hij heeft het echter zooveel mogelijk geschoeid op de leest der talrijke luchtige godenliefdes, speciaal der avonturen van preutsche jageressen, die bij de alexandrijnsche dichters zeer geliefd waren en ook door Ovidius met veel genoegen in de eerste boeken der Metamorphosen zoowel als elders verteld worden. De dichter benut een maximum aan overgeleverde motieven : dit is de vindingrijkheid, die hij in dit "origineele" verhaal aan den dag legt. De verklaring hiervan is, dat hij een Romeinsche tegenhanger wilde scheppen van de luchtige Grieksche verhalen, die zulk een furore maakten. De vraag, of hij in de uitwerking van de intrigue "origineel" had kunnen zijn, is stellig interessant, doch mag ons geen oogenblik doen vergeten, dat hij het niet 
heeft willen zijn. Zoo speelsch en "Grieksch" te kunnen dichten over goden van den eigen Italischen bodem gaf hem niet slechts een meer dan gewone voldoening, doch was hem ook een eer en een glorie. Het alexandrijnsch karakter van dit verhaal is voor Ovidius geen testimonium paupertatis, doch een testimonium aequitatis. In „Pomona” met zijn sprankelende ironie biedt Ovidius aan stad en wereld zijn Romeinsch specimen van de alexandrijnsche (moderne) godenliefde, zooals hij in de apotheoses der laatste boeken, speciaal in die van Caesar, een Romeinsch specimen geeft van de alexandrijnsche (moderne) hofpoëzie. Dat Ovidius in zijn opzet geslaagd is, valt niet te betwijfelen ; "Pomona" wordt gunstig onthaald. R ibbeck (p. 300) spreekt van een zweem van humor in dit verhaal; $L$ a f a ye (Met. p. 232/4) weet er de gratie, de ondeugendheid, fijnheid en discrete ironie van te waardeeren. Het genot ervan wordt in hooge mate vergroot door de vertelling van Iphis en Anaxarete, die Ovidius Vertumnus laat debiteeren, een parodie van de sentimenteele alexandrijnsche liefdesverhalen en van de erotische elegie; doch de bespreking hiervan valt buiten het bestek van deze studie.

\section{SABINI REPULSI (XIV 778-804)}

Voor de godenschildering levert dit verhaal weinig op; wij wijden er echter enkele woorden aan, om een argument van $\mathrm{He}$ in ze te ontzenuwen. Ovidius geeft van den nachtelijken overval der Sabijnen op den belegerden burcht der Romeinen twee versies, één in de Metamorphosen, één in de Fasti (1.260/76). Over de belangrijke verschillen tusschen beiden heeft $\mathrm{He}$ in ze (p. $36 \mathrm{v}$.) reeds het voornaamste gezegd. In de Metamorphosen ontwerpt de dichter zelf een episch beeld dezer episode, in de Fasti keuvelt Janus gemoedelijk over een avontuur uit het grijs verleden. Ligt in de Metamorphosen het zwaartepunt op de metamorphose der koude bronnen in zwavelbronnen, het referaat der Fasti loopt uit op de verklaring van de stichting van een Janustempeltje. Opmerkelijke zakelijke verschillen zijn door stylistische overwegingen ingegeven. Terwijl in de Fasti Janus de held van het verhaal is, die door zijn ingrijpen den overval tot mislukking doemt, verijdelt in de Metamorphosen Venus met behulp van de naburige nymphen Juno's boozen opzet : Ovidius geeft in de Metamorphosen de hoog-epische lezing, en laat daarom Venus, der Aeneaden stammoeder, de hoofdrol spelen, terwijl Juno, als steeds in het epos (Ennius, Vergilius), de tegenstreefster der Romeinen is. Ovidius is zich dus van het onderscheid tusschen de epische vertelling en de niet-epische wel bewust. Hij heeft in dit verhaal echter zichzelf den dwang opgelegd van een dubbele versie; daarom mag deze episode niet als argument dienen, zooals dit bij $\mathrm{He}$ in ze geschiedt, voor de algemeene stelling, dat Ovidius in de Metamorphosen zijn stof episch, in den zin van officieel, waardig en verheven, inkleedt. Het bewijst enkel, dat Ovidius wist, dat er ook een episch-officieele wijze van inkleeding was. Doch als de dichter elders, waar hij zich niet onder uitwendigen dwang heeft gesteld, hiervan geen aanhanger is, pleit dit verhaal, als een uitzondering op den regel, juist tegen $\mathrm{He}$ in $z e$ 's algemeene stelling.

Over de acties der goden in dit verhaal wordt te schematisch gesproken, dan 
dat hieruit iets voor de godenschildering kan worden afgeleid. Het eenige punt, dat om verklaring vraagt, is de kwestie van Juno. Bij de apotheose van Aeneas heette zij verzoend te zijn $(581 \mathrm{v}$.) ; hier is zij weer aan de zijde van de vijanden. Wichers (p. 63 v.) verklaart deze tegenspraak hiermede, dat Ovidius, omdat hij Metamorphosen en Fasti gelijktijdig opwerkte, Juno's verzoening bij Aeneas' apotheose vergeten was, toen hij aan den nachtelijken overval der Sabijnen werkte. Dit is overbodig en onjuist. De kwestie is veel eenvoudiger. Ovidius bekreunt zich om dergelijke inconsistenties niet. Met een variant op het bekende vers expedit esse deos et, ut expedit, esse putemus kan men zeggen : het is dienstig bij Aeneas' apotheose, dat Juno verzoend is; welnu, het zij zoo ; en : het is dienstig, dat in de epische versie van den aanslag der Sabijnen de intrigueerende Juno optreedt uit de traditioneele Romeinsche historische epiek; welnu, zij intrigueere. Oogenblik gaat voor eeuwig.

\section{ROMULI APOTHEOSIS ET HERSILIAE (XIV 805-851)}

Romulus en zijn gemalin Hersilia worden vergoddelijkt onder de namen Quirinus en Hora Quirini. De gelijkschakeling van Romulus en Quirinus schijnt niet op Ennius terug te gaan (W is sow a R. K. p. 155 n. 5). Over de apotheose van Hersilia is ons uit Ennius niets bekend. Daarentegen is het zeker, dat er in Ennius' Annalen sprake was van de ten hemel opneming van Romulus. De eerste vraag, die wij, zoover mogelijk, moeten beantwoorden, betreft de verhouding tusschen Ovidius en Ennius.

De ten hemel opneming van Romulus wordt voorafgegaan en ingeleid door een verzoek van Mars aan Juppiter. Omtrent een godenraad, aan Romulus' vergoddelijking onmiddellijk voorafgaande, is ons uit Ennius niets bekend, terwijl ook wel uit Ovidius' woorden volgt, dat er bij Ennius ook geen geweest is. Want, eerstens, ook bij Ovidius is er van een godenraad geen sprake, hetgeen ongetwijfeld wel het geval zou zijn geweest, als hij hem bij Ennius had aangetroffen. Het is slechts een onderhoud tusschen Mars en Juppiter; uit niets blijkt de aanwezigheid van andere goden. Deze was ook niet noodzakelijk, want, tweedens, Juppiter stemt niet toe in de apotheose, doch geeft slechts verlof om tot de uitvoering ervan over te gaan. Het gaat niet, zooals bijv. bij de apotheose van Aeneas, om een principieele beslissing, doch enkel om het tijdstip van uitvoering; daarom is hier geen godenraad noodig. De beslissing was reeds eerder gevallen. Mars verwijst uitdrukkelijk naar de zitting, waarin Juppiter de apotheose toezegde, en haalt daarbij de beslissende woorden aan als het ware uit het verslag der vergadering (dat hij in zijn geest "genoteerd" heeft, 813) : unus erit, quem tu tolles in caerula caeli: dit is Ennius (ann. 65) formeel citeeren; men kan vergelijken uit Fasti III de woorden van Ariadne, waarbij, door memini, uitdrukkelijk verwezen wordt naar Catullus (471 vv. : Cat. 64. 132/201). In dien godenraad nu was - blijkens unus, dat, waar het een tweeling betreft, een alter veronderstelt (tenzij het vers bedoelt te zeggen, dat Mars slechts één sterveling ten hemel zal opnemen) - van Romulus en Remus sprake, over wier lot gedelibereerd werd, terwijl zij nog in leven waren ; Romulus' apotheose ligt nog in het verschiet. Aan Remus' lot herinnert Mars in de Fasti-versie van dit verhaal, waar- 
over nog gesproken zal worden. Bij welke gelegenheid zou deze godenraad gehouden zijn? Het meest in aanmerking komt het moment, dat zij te vondeling gelegd, of dat zij gered worden ( $\mathrm{E} \mathrm{h}$ w ald ad 804). Tenzij men aanneemt, dat ook bij Ennius een gesprek tusschen Mars en Juppiter onmiddellijk voorafging aan de ten hemel opneming van Romulus, blijkt dus, dat het onderhoud tusschen genoemde goden door Ovidius verzonnen is, als inleiding op de eigenlijke actie, doch in aansluiting van een Enniaanschen godenraad. Ook in de schildering der uitvoering zal Ovidius wel van Enniaansche motieven gebruik gemaakt hebben, doch de Enniaansche versie ontbreekt, zoodat wij geen vergelijking kunnen trekken. Wellicht vinden wij, behalve in het geciteerde vers, nog een tweede Enniaansche reminiscentie in Ovidius. Hij omschrijft Juppiter als divumque hominumque parentem (807). E h w ald verwijst naar Vergilius' hominum sator atque deorum. Of sator door Ennius gebezigd is, weten wij niet. Treffender echter is de overeenkomst met de Enniaansche formules divumque hominumque pater rex (ann. 580) en patrem divumque hominumque (ann. 581); uit welk boek elk stamt, is onbekend. De variant patrem : parentem is onbelangrijk, daar de gedeclineerde vormen van parens voor het verseinde zeer geschikt en gebruikelijk zijn.

Ovidius bouwt dus in het gesprek tusschen Mars en Juppiter zelfstandig voort op Ennius. Vergelijken wij thans de beide versies, die Ovidius hiervan geeft, die der Metamorphosen en die der Fasti (2.481 vv.). Er is tusschen beiden een hemelsbreed verschil ( $\mathrm{He}$ in ze p. 17 v., 39 vv.). In de Metamorphosen vraagt Mars als hoeder der res Romana aan den opperbestierder van hemel en aarde voor den stichter van Rome de apotheose als belooning. In de Fasti vraagt hij als vader aan zijn vader voor zijn zoon de apotheose als een gunst en een schadeloosstelling voor het gemis van Remus. De tegenstelling is volledig en, natuurlijk, gewild : in de Metamorphosen louter officieele motieven en wereldpolitiek, in de Fasti een zuiver particuliere aangelegenheid, met sterken nadruk op de familierelaties. Ovidius heeft zich in de beide versies van dit verhaal onder een stylistischen dwang gesteld. Wij mogen de voorstelling der goden, hier in de Metamorphosen geschilderd, niet als normaal opvatten, zooals $\mathrm{H}$ e in z e doet. Het is een uitzonderlijk geval, en de uitzondering bevestigt op ideale wijze den regel : want daar, waar Ovidius zich vrij kon bewegen, zooals bijv. in de apotheose van Aeneas, gaat hij juist te werk als in wat door $\mathrm{He}$ in ze genoemd wordt de „elegische" versie der Fasti. Aan den anderen kant bewijst de „epische” versie der Metamorphosen, dat Ovidius èn het besef van èn de capaciteiten had tot de officieele voorstelling van zaken. Hij heeft deze dus in de apotheose van Aeneas niet gewild. Hiermede is het bewijs geleverd van Ovidius' principieel alexandrinisme, gekenmerkt vooral door vermenschelijking. Ovidius geeft in de beide versies van Romulus' apotheose een stylistische show.

In het vervolg van dit verhaal in de Metamorphosen blijkt, dat Ovidius deze apotheose ook opvat als een stuk hoofsche poëzie. Dit bewijst eerstens de plaats van ontvoering, door hem gekozen. In de Fasti is dit, volgens de traditie, het Geitenmoeras; in de Metamorphosen echter de hoogste top van den Palatijn : een welbewuste innovatie dus. Waarom de Palatijn? H e in ze (p. 39) geeft een louter litteraire verklaring: de Palatijn is, als verhevener scaena, meer in over- 
eenstemming met de waardigheid per epiek. Doch waarom juist de Palatijn gekozen, en niet de Quirinaal, die toch om den tempel van Romulus-Quirinus uitstekende papieren had? Wichers (p. 67) meent, ten deele terecht, dat de Palatijn gekozen werd, omdat deze ten tijde van Augustus caput urbis was. Beslissend is echter, dat op den Palatijn volgens de sage het paleis van Romulus gestaan had en dat er thans resideerde de nieuwe Quirinus, zooals Augustus zich gaarne liet noemen (Sueton. Aug. 7; W is sow a R. K. p. 155 n. 8; Cassius

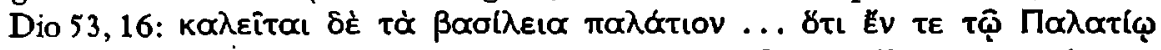

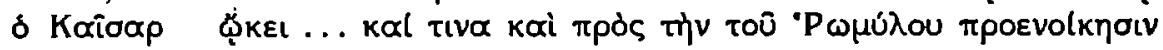

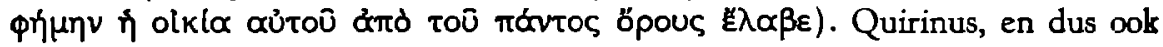
zijn beeld, stond in het teeken der politieke belangstelling. Welnu, tweedens, in de verzen, gewijd aan de nieuwe gestalte van den vergoddelijkte - schoon en de pulvinaria alta waardig, kortom est qualis trabeati forma 2uirini - verwijst Ovidius onmiskenbaar naar het standbeeld van Quirinus-Romulus ( $\mathrm{k} h \mathrm{wald}$ ad 828), zooals hij dat ook enkele malen doet in de Fasti (trabeati 2uirini, 1.37; pulcher et humano maior trabeaque decorus, 2.503 ; lituo pulcher trabeaque 2uirinus, 6.375). Wellicht ook niet zonder een zijdelingschen blik op den nieuwen Quirinus heet het, dat Romulus non regia iura (823) sprak.

Tot zoover spraken wij van het officieele moment in de godenschildering. In het volgende, de schildering van Mars, zooals hij ter aarde vaart, treedt, dunkt mij, naast het hoogepisch moment een zeker moment van personificatie. Het is een vervaarlijke god, die hier gegeven wordt: staande op zijn bloedbedropen wagen, leunend op zijn lans, knallend met de zweep. Moet hij zoo de oorlogenrijke regeering van Romulus verbeelden, die nu een eind neemt, nu de res Romana hecht gefundeerd is en hij posita casside tot Juppiter kan komen? Wordt Romulus ten hemel opgenomen op den nog bloeddruipenden wagen? Zeker past een grootsch beeld bij het grootsch gebeuren; doch Mars' houding is wel al te Martiaal, als wij bedenken, dat hij ditmaal toch niet ten strijde trekt. Mars is de god des oorlogs, en als zoodanig moet hij even Martiaal zijn als de god des slaaps slaperig, of Pluto duister en vervaarlijk, of Boreas „van huis uit" bulderend. Mars komt posita casside tot Juppiter : het is niet alleen een gebaar van eerbied en onderdanigheid; het geeft ook aan, dat hij even zijn krijgsbedrijven staakt : cf. Bellice, depositis clipeo paulisper et hasta, Mars, ades et nitidas casside solve comas (F. 3. 1/2); ook herinnert het even aan de voorstelling van den god, uit de beeldende kunsten bekend (vergelijk nog : sic ego, sic posita Titonia cuspide dixit, F. 6.655).

Vervolgens moeten wij wijzen op het rationalistisch element in dit verhaal. Hoogstmerkwaardig is de wijze, waarop de lustratie van den stoffelijken Romulus zich voltrekt. De voorstelling van zaken is geestrijk rationalistisch. De lustratie lijkt wel een natuurproces : door den snellen opwaartschen gang gaat het stoffelijk omhulsel in lucht op : dit weet de dichter plausibel te maken door een wetenschappelijke vergelijking: de vergelijking van den opgloeienden looden kogel (825 v.; zij komt in andere termen ook $2.727 \mathrm{vv}$. voor) gaat terug op Lucretius (6. 177 vv., 306 vv.; voor een andere "wetenschappelijke" vergelijking naar Lucretius vergelijk Ov. 9.220 vv. en Lucr. 6.495 vv., 527). Mars ontvoert slechts; 
de lustratie gaat buiten hem om. Het bovennatuurlijk gebeuren wordt genatu raliseerd. Epiek met haar godenapparaat sluit een morganatisch huwelijk met de natuurkunde. De „synthese" geschiedt door de esprit. Er is iets centaureïsch in deze voorstelling van zaken. Wij worden herinnerd aan het spel met de dupliciteit der eponyme godheden. De verbindingsschakel tusschen beide strijdige elementen is hier de snelle vaart van Mars' wagen.

Iets dergelijks vinden wij ook in de apotheose van Hersilia. Ook daar vinden wij een natuurlijke verklaring : een comeet, uit den hemel neerschietend, zet haar haren in vlam (de dichter herinnert ons een moment aan het motief der vlammende haren, uit Vergilius $2.682 \mathrm{vv}$. en $7.73 \mathrm{vv}$. welbekend), en met de ster gaat Hersilla in (de) lucht op. Deze comeet echter is het onpersoonlijk instrument, dat door Juno gebruikt wordt ; Juno zelf wordt evenwel niet uitdrukkelijk als auctor genoemd. Indrukwekkend is het niet, wel ingenieus. De verklaring voor deze rationalistische voorstelling van zaken ligt in het ingenieuze spel, dat Ovidius overal in de Metamorphosen speelt met de metamorphosen, waarvan hij het proces steeds gedetailleerd schildert. Welnu, de apotheose is een metamor. phose ; als zoodanig kon zij in de Metamorphosen opgenomen worden. Hercules' lichaam wordt een prooi der vlammen, naar de traditie; Aeneas' lichaam is naar de traditie een prooi van de rivier de Numicius; om adulatorische redenen stelt de dichter het voor, dat de riviergod op bevel van Venus de lustratie verricht. Bij de apotheoses van Romulus, van Hersilia, en, zooals wij nog zullen zien, van Caesar, kan geen godenapparaat Ovidius van het gebruikelijke jeu d'esprit terughouden.

Tenslotte vraagt de verhouding tusschen Romulus en Hersilia onze aandacht. Juni zendt Iris tot de treurende. Dergelijke opdrachten zijn uit de epiek welbekend. Ovidius gebruikt het gewone godenapparaat; er is niets bijzonders te melden. Opmerkelijk is echter de teekening van Hersilia : niet de stoere antieke matrone, doch naar modernen smaak omgevormd tot de romantisch-sentimenteele weduwe in den geest van een Alcyone. Zij verlangt onstuimig naar den beminde: duc, o duc - et offer (842). Met zijn typische comische ironie laat Ovidius haar zeggen, de aanstaande godin, dat hem nog eenmaal te zien voor haar beteekent caelum accepisse (844). Haar smart is verklaarbaar; want Romulus was blijkbaar een teeder-minnende echtvriend: hij ontvangt haar dan ook liefdevol in den hemel manibus notis (849). Met luttele woorden weet aldus Ovidius ons het bloedlooze sacrale paar Quirinus en Hora Quirini menschelijk (modern-menschelijk) nader te brengen. Wij hebben hier een uitstekend voorbeeld, hoe één of enkele woorden een geheel eigen licht kunnen werpen op een bepaalde situatie. Manibus notis is voor ons van het hoogste belang : hierin ligt heel een vermenschelijking besloten. Deze twee woorden zeggen ons meer over Ovidius' godenschildering dan heel de rede van Mars. Wat de alexandrijnsche godenschildering zoo sympathiek maakte, zoo levensecht en menschelijk, onderneemt Ovidius ook aan de Romeinsche goden, en niet alleen aan een Pomona en Vertumnus, doch ook aan een "politieken” god als Quirinus. De rede van Mars getuigt slechts van Ovidius' stylistisch kunnen, doch in de schildering van Quirinus en zijn Hora komt de eigenlijke tendenz zijner godenschildering aan het licht: glim. lachende vermenschelijking. 
Het verhaal van het overbrengen van het Aesculapiusbeeld naar Rome vangt alsvolgt aan :

Pandite nunc, Musae, praesentia numina vatum, 622

(scitis enim, nec vos fallit spatiosa vetustas,)

unde Coroniden circtimflua Thybridis alti

insula Romuleae sacris adiecerit urbis.

Opvallend is in de eerste plaats, dat de Muzen aangeroepen worden; het is in de Metamorphosen de eenige maal, dat de dichter dit zelf doet. Het carmen perpetuum wordt er formeel mee onderbroken ( $\mathrm{Sch} \mathrm{midt} \mathrm{p.} \mathrm{104).}$ Opvallend is vervolgens, dat uitdrukkelijk gezegd wordt, dat het volgende een sacraal aition zal zijn. Daarbij komt nog, dat er in dit verhaal nauwelijks van een metamorphose sprake kan zijn, omdat de god slechts tijdelijk den vorm aanneemt van de slang, hetgeen een zwakke rechtvaardiging is van de opname van dit verhaal in den krans der Metamorphosen. Ovidius heeft dus het uitzonderlijk karakter van dit verhaal onderstreept. Is de Muzenaanroeping een noodsprong? Dan heeft de dichter van den nood een deugd gemaakt. Want hij heeft, dunkt mij, plechtig willen aankondigen, dat hij in het volgende een aition zal geven in statig epischen stijl, dat in contrast zou staan met de „elegisch" gestyleerde aitia der Fasti, in het bijzonder met het verhaal van de inhaling van het beeld der Magna Mater (4. 249 vv.), dat met dat van de inhaling van Aesculapius thematisch zulk een groote overeenkomst vertoont. He in ze (p. 13 n. 1) verwijst naar het verhaal der Magna Mater, doch werkt dit idee niet uit. Voor deze verklaring, dat nl. Ovidius dit verhaal geschreven heeft als den epischen tegenhanger van dat der Magna Mater, pleit het volgende: er is sprake van een gezantschap naar Delphi; dit is de oorzaak van een dood punt in de handeling ; want eerst zendt men een gezantschap naar Griekenland, het orakel wordt te Rome gerapporteerd; daarna zoekt men naar de stad van Apollo's zoon, en vervolgens wordt een nieuw gezantschap naar Griekenland gezonden. $\mathrm{Nu}$ heeft het eerste gezantschap in feite anno 293/2 niet plaats gehad; men raadpleegde de Sibyllijnsche boeken (Liv. 10.47.7). De dichter heeft het gezantschap verzonnen, èn omdat het indrukwekkender is een orakel te raadplegen dan boeken en om een meer gelede handeling te krijgen. Hij kreeg zoo gelegenheid op episch-breede wijze het consult en de orakelspreuk van Apollo te beschrijven, waarover hij in het verhaal der Magna Mater op uiterst eenvoudige wijze gehandeld had (vgl. E hwald ad 630). Het contrast tusschen beide consulten is volledig.

Fasti : consulitur Paean „divum" que „arcessite Matrem”, 263 inquit „in Idaeo est invenienda iugo."

Metam. : auxilium caeleste petunt mediamque tenentis 630 orbis humum Delphos adeunt, oracula Phoebi, utque salutifera miseris succurrere rebus sorte velit tantaeque urbis mala finiat, orant: 
et locus et laurus et, quas habet ipse pharetras, intremuere simul, cortinaque reddidit imo

hanc adyti vocem pavefactaque pectora movit:

„2uod petis hinc, propiore loco, Romane, petisses, et pete nunc propiore loco: nec Apolline vobis, qui minuat luctus, opus est, sed Apolline nato. ite bonis avibus prolemque accersite nostram."

Tegenover den grootst mogelijken eenvoud, bondigheid, zakelijkheid en helderheid der Fasti staat in de Metamorphosen verhevenheid, breedvoedigheid, plechtstatig. heid en duisterheid, het orakel eigen. Ter versterking van den statigen indruk makt Ovidius in de Metamorphosen bovendien gebruik van talrijke reminiscenties uit de Aeneis. Hier wordt men herinnerd aan de scene tusschen de Sibylle en de Trojanen in Aeneis VI; vgl. voor vers 636 bijv. Vergilius 54 v. en 98. Vergelijk ook Ovidius 677 'en, deus est, deus est!' met Vergilius 46 ,deus ecce deus'. De nachtelijke verschijning van Aesculapius herinnert aan de nachtelijke verschijning der Penaten en van pater Tiberinus bij Vergilius (3. 147/78; 8. 26/67). Nu staat deze nachtelijke verschijning van Aesculapius weer in stylistisch contrast met de nachtelijke vermaning der Magna Mater aan Attalus in de Fasti (267/72), die gekenmerkt wordt door berekenden eenvoud, terwijl een persoonlijke opmerking van den dichter (mira canam) niet ontbreekt.

Ovidius wil hier dus, in herinnering aan Vergilius, een bij uitstek episch en verheven gestyleerd aition geven, en het is niet vermetel, het op te vatten als een contrast met het „elegisch" gestyleerd aition der Magna Mater uit de Fasti. Indien dit waar is, valt dit verhaal onder de categorie der dubbele versies, waaronder de apotheose van Romulus valt, die een uitzonderlijk karakter dragen en geen bewijskracht hebben voor een algemeene stelling omtrent Ovidius' godenschildering in de Metamorphosen, zooals $\mathrm{He}$ in ze doet, die de uitzonderingen voor den regel verslijt. Vanwege het contrast met het aition der Fasti wordt hier de god verheven voorgesteld, sprekend in kalme majesteit (placido tales emittere pectore voce, 657), in die verhevenheid, die de caelestia corpora (662) past. Te roemen valt, hoe de dichter den horror sacer heeft weten te wekken èn door de schildering van de houding van den god èn door de schildering van de reactie der aanwezigen ( $\mathrm{He}$ in z e p. 13). Dit valt te meer op, daar de in serpente deus (670) gernakkelijk aanleiding zou hebben gegeven tot allerlei speelsche en verrassende details. Ovidius verstond de kunst wel, om, indien noodig, de goden zelfs onder de moeilijkste omstandigheden majesteitelijk uit te beelden, zoo leert ons dit uitzonderingsgeval, en dit geeft des te meer relief aan de normale gevallen, waarin hij dit niet heeft gedaan : hij kan wel, doch wil niet.

\section{CAESARIS APOTHEOSIS (XV 745-870)}

Caesar werd na zijn dood tot god verheven. Tijdens de spelen, door Augustus na Caesar's vermoording ter eere van Venus Genetrix gegeven, nam men een opvallende ster waar, die als de ziel van den vergoddelijkten Caesar werd geduid. Uit dit gegeven heeft Ovidius het slotstuk gemaakt zijner Metamorphosen, een 
„schallende fanfare" ( $R$ ib be ck p. 311). Hij begint met te verklaren, dat Caesar niet zoozeer door zijn triumfen als staatsman en veldheer alswel door zijn zoon in een comeetster veranderd is, een hoogstgedurfde stelling, die hierdoor verklaard wordt, dat het Caesar's grootste daad was de vader te zijn van zulk een man, onder wien de zegen des hemels rijkelijk over het menschelijk geslacht is neergedaald. Opdat Augustus niet van menschelijke afstamming zou zijn, moest Caesar tot god gemaakt worden, - bijna zouden we zeggen, gebombardeerd worden. Het is adulatie, doch spitsvondig, een geestrijk spel. De inleiding bewijst, als dit nog noodig mocht zijn, dat de apotheose van Caesar een huldiging en verheerlijking moet zijn van den keizer zelf. Het is hofpoëzie, zooals ook Callimachus die schreef : men kan denken aan de Coma Berenices of den Arsinoethrenos van dezen dichter.

De aardsche handeling laat de dichter bijna geheel verdwijnen achter een goddelijke handeling, waarin de aardsche zich weerspiegelt. Curie en Olympus, aarde en hemel, worden volgens het traditioneele systeem der epiek met elkaar verbonden. Aangezien het de verheerlijking der keizerlijke familie betrof, was Venus Genetrix de angewezen pleitbezorgster. De moord op den pontifex maximus Caesar, den priester van Vesta, komt op de tweede plaats. In de Fasti, de sacrale, werd vooral op de vermoording van Vesta's priester de nadruk gelegd, reden waarom daar Vesta ingrijpt (3.697/710). Vesta beweert haar priester aan de snoode handen der moordenaars ontrukt te hebben en in zijn plaats een $\varepsilon \Uparrow \delta \omega \lambda$ ov te hebben achtergelaten. Ook in de Metamorphosen wordt Caesar's priesterschap wel even aangestipt $(763 ; 778)$, doch het is slechts een nevenmotief, welks invoeging den dichter niet bijster gelukt is, waarvan de versterkende kracht gering is, een haastige echo van de versie der Fasti. In de Metamorphosen is de stammoeder van het Julische geslacht de protagoniste ; zij zet haar bemoeienissen om Aeneas in diens afstammeling voort. $\mathrm{Z}_{\mathrm{ij}}$ wordt omschreven als Aeneae genetrix ; zij noemt Caesar den eenigen telg, die haar nog blijft van Julus (Iulius, a magna demissum nomen Iulo, Verg. 1.288). Door Julus het epitheton Dardanius toe te voegen, sluit de dichter zich ook in de formuleering nauw bij Vergilius aan. Deze omschrijft Julus als Dardanius nepos Veneris (4.163) en Veneris iustissima cura Dardanius puer (10.132 v.); Dardanius wordt door Vergilius weliswaar niet direct bij den eigennaam Julus gevoegd, doch wel bij de eigen. namen Aeneas $(1.494 ; 6.169 ; 11.472)$, Anchises $(1.617 ; 9.647)$ en Acestes $(5.30 ; 711)$. Venus herinnert aan de zorgen, die zij reeds voor Troje om Aeneas had en aan diens zwerftochten en oorlogen in Italië. Door deze aansluiting bij de Aeneis en door dit ,historisch perspectief' stelt de dichter Venus' bemoeienissen om Caesar voor als de logische voortzetting en bekroning der Aeneis. Hij verstaat het Caesaris in Phrygios condere nomen avos (Prop. 2. 1. 42).

Zeer merkwaardig is nu, dat in dit dynastiek en hoog-episch verband Venus zich $z 00$ onbeheerscht gedraagt, in feite te keer gaat. $\mathrm{Zij}$ verbleekt, zij klampt, om stemming te maken (reeds bij de apotheose van Aeneas sprak Ovidius van haar ambire), iederen god aan, dien zij tegenkomt, klaagt mateloos en rakelt al het oude zeer weer op, van haar verwonding door Diomedes tot den oorlog met Turnus toe, of liever, zooals zij zegt, met Juno. $\mathrm{Z}_{\mathrm{ij}}$ mist alle zelfbeheersching, wij 
zien haar als het ware de handen wringen, de tragedienne, terwill zij jammert : .adspice' dicebat ,quanta mihi mole parentur Insidiae - (765 v); solane semper ero ustis exercita cuns (768; echo van Vergilus' at Venus interea Neptunum, exercita curns, Adloquitur talisque effundit pectore questus, 5.779 v.); en acur sceleratos cernitis enses? (776). Zoo vervult $z$ ij "mit kindischen Klagen" ( $\mathrm{R}_{1}$ b beck p 311) den ganschen hemel $\mathrm{Er}_{\mathrm{r}}$ is een zekere overeenkomst tusschen deze haar expectoratie en de rede van Venus in Aene1s X (18/62). Tot schreiens toe bewogen door de precaure situatie der Trojanen en Juno's gnimmig, nuets ontziend optreden, levert zij daar een hartstochteljkk betoog en gaat zoover, dat zij zegt van de haar toegezegde heerschappij af te zien. Vrouwelijke gevoeligheid en vrouwelıke diplomatie gaan her hand in hand; aldus hoopt zij aan haar beroep op Juppiter's rechtvaardigheidsgevoel kracht bij te zetten Hier, zoowel als bij haar gesprek met Juppiter in Aene1s I en met Neptunus in Aene1s V, strnjdt zij met haar wapenen voor de zending van haar geslacht Als zij zich laat gaan in haar ontroeningen, weet zil, dat zil zich laat gaan; zil blyft ondanks alles de godin. Hiervan zijn wij bij Ovidius niet overtugd Ovidius' realistische schuldenng ontneemt, ondanks en mede door de Verglliaansche reminiscenties, alle waardigheid aan haar optreden Venus wordt voor een verheven godın al te zeer vermenschelijkt.

De goden, bewogen doch net bij machte de ijzeren besluiten der Parcen te niet te doen, kondigen door voorteekenen de aanstaande ramp aan Volgt een lange reeks van voorteekenen, die met Caesar's vermoording in verband staan, vnj bewerkt naar die, welke Verglius aan het eind van Georgica I (467/88) beschreef en die door Tibullus (2.5.71/78) gerefereerd waren. Vergelijken wij Ovidus met Vergilius. Vergilius geeft de volgende reeks : zonsverdusternng; voorteekenen aan land en zee; honden en vogels; vulkaanuitbarstingen (Aetna); wapengekletter (Germanua), aardbevingen (Alpen), stemmen in hellıge wouden; schımmen; dieren, die spreken; nvieren, dre stokken; landen, die opengapen; godenbeelden, die weenen en zweeten, overstrooming (Endanus); teekenen bij de offerschouw; bloedige druppels; hulende wolven in de steden; bliksem bij helderen hemel ; cometen. Ovidius geeft de volgende reeks : wapengekletter; geschetter van tubae en cornua, zonsverdustering ; cometen ; bloedige druppels ; caerulus Lucifer, luna sangurnea, bubo, godenbeelden, dre weenen, gezang en stemmen ut hellige wouden; teekenen blj de offerschouw, hondengehul; schimmen, aardbevingen (Tibullus: cometen, steenenregen, tubae, cornua; stemmen ut hellige wouden; zonsverdustenng, godenbeelden, die weenen; runderen, die spreken) Vergilius streeft ernaar de algemeen bekende en conventioneele voorteekenen, uit Livius welbekend, te specialiseeren . niet enkel uit Rome en Italie, doch uit alle deelen des rijks, uit Siclie en uit Germanie, van de Alpen en den Endanus worden booze teekenen gemeld Dit wereldomspannend net van prodigia, dat wisst op een ramp van wereldomspannende importantie, maakt de opsomming indrukwekkend $B_{1 j}$ Ovidius daarentegen komen geen geographische specificaties voor; indien wij aan een bepaalde plaats moeten denken, dan is het Rome en naaste omgeving. Slechts éénmaal, en wel indrrect, vinden wij een geographische aanduiding : inque foro crrcumque domos et templa 
deorum Nocturnos ululare canes (796 v.). Ovidius contamineert hier wel van Vergilius obscenaeque canes (niet nader uitgewerkt) en et altae Per noctem resonare lupis ulutantibus urbes; honden dus in plaats van wolven, en wel (wegens forum, huizen, tempels) Rome in plaats van het meervoudige altae urbes. Ovidius geeft dus een opsomming van meer typische, algemeen en herhaaldelijk voorkomende voorteekenen, die geen bepaalde locale kleur vertoonen. Het conventioneel karakter der Ovidiaansche opsomming blijkt echter niet enkel uit hetgeen is weggelaten, doch ook uit de aanvullingen. Er wordt niet enkel wapengekletter vernomen (Vergilius), doch ook bazuingeschal, en niet enkel tubae, doch ook cornua; een systematische opsomming dus van wat men de martiale mogelijkheden zou kunnen noemen (op het onderscheid tusschen beide instrumenten wees Ovidius reeds 1.98 : non tuba directi, non deris cornua flexi). Verder zijn bij Vergilius de hemelteekenen over de gansche opsomming verspreid; hij begint met zonsverduistering, spreekt eerst veel later over de bloedige druppels, en eindigt met de cometen in den nacht. Ovidius plaatst deze verschijnselen terstond achter elkaar en voegt er nog den caerulus Lucifer en de luna sanguinea aan toe. Het is, alsof hij de vraag beantwoordt, welke teekenen zooal aan den hemel mogelijk zijn, waarbij hij niet vergeet onderscheid te maken tusschen dag en nacht en overgang, en naast de sterren de maan te vermelden. Op het conventioneel karakter der Ovidiaansche opsomming wijst echter ook de specificatie van Vergilius' algemeen gehouden inportunae volucres tot den conventioneelen vogel des onheils, den funereus bubo (vgl. $10.453 ; 5.549$ v.), dien Vergilius reeds in de passage der voorteekenen in Aeneis IV had genoemd (462). Ovidius geeft dus een opsomming van voorteekenen in het algemeen, in verband gebracht met Caesar's vermoording; hij maakte gebruik van, de passage der Georgica, zonder zich hieraan gebonden te achten. Het voornaamste verschil met Vergilius is echter, dat bij dezen, overeenkomstig de historie (occiso Caesare et Antoniano bello, Plin. N.H. 2.98), de voorteekenen nà Caesar's vermoording plaats grijpen en op Philippi wijzen (exstincto Caesare - Philippi, 466-489), terwijl zij bij Ovidius aan den moord voorafgaan, zijnde teekenen van waarschuwing, zooals zoowel aan het begin als aan het einde der opsomming gezegd wordt $(782 ; 799)$. Bij groote overeenkomsten dus tusschen beide dichters zijn er ook groote verschillen; Ovidius heeft aan zijn opsomming een eigen karakter gegeven, en de opsomming aan zijn doel volkomen ondergeschilt gemaakt.

De voorbereidingen tot den aanslag, dien tactische en artistieke overwegingen verboden te beschrijven, worden in een enkele treffende flits afgedaan : strictir que feruntur In templum gladii $(800$ v.). De scene wordt echter weer snel naar den Olympus verplaatst :

$$
\begin{aligned}
& \text { tum vero Cytherea manu percussit utraque } \\
& \text { pectus et Aeneaden molitur condere nube, } \\
& \text { qua prius infesto Paris est ereptus Atridae, } \\
& \text { et Diomedeos Aeneas fugerat enses. }
\end{aligned}
$$

Ook hier vinden wij weer vereenigd Venus' onbeheerscht gedrag en het aanknoopen van de banden met het verleden. Het idee om Venus te laten over- 
wegen om, zooals Parss en Aeneas in de Ilias, ook Caesar aan de handen zinner tegenstanders te ontrukken, is wellicht ingegeven door de versie der Fast1, waar Vesta beweert, in de plaats van den ontrukten Caesar een $\varepsilon$ í $\delta \omega \lambda$ ov geplaatst te hebben, zoodat slechts Caesar's schaduwbeeld door het zwaard viel Het is een geschikte kunstgreep, ontleend aan het epos, dat handelt over het gnjs verleden, doch die ook in het felste licht van critische tijden een goddelyk ingrijpen onaantastbaar maakt. Ook in de Metamorphosen had Ovidius deze kunstgreep kunnen toepassen; Venus had Caesar kunnen ontrukken en in zijn plaats een schaduwbeeld achterlaten, bij de opwaartsche vlucht had dan het stoffelijk omhulsel verteerd kunnen worden. Waarom deed hij dit niet, waarom redde hij de eer nuet geheel? De verklanng ligt wel hern, dat zoo de apotheose een hinderlijke doublette zou zijn geworden van die van Romulus $B_{1 j}$ Romulus moest volgens de traditie het lichaam van de aarde verdwijnen; bij Caesar viel alle nadruk op de ziel, de ziel, die zich in de comeet had gemanifesteerd tijdens de spelen. Als Juppiter dan ook aan Venus verlof geeft, Caesar's ziel in een ster te veranderen, komt $z_{1 j}$ in den senaat, null cernenda natuurlyk, en neemt de ziel uit het lichaam mede. Aldus weet Ovidius Venus persoonlijk te laten ingrijpen op zulk een wijze, dat aan de histonsche feiten geen geweld wordt aangedaan. De actie, welke hij Venus toeschrifft, heeft het voordeel, dat zil, wijl oncontroleerbaar, onaantastbaar is.

Venus' voornemen echter om haar afstammeling in een wolk te hullen om hem te ontrukken is de aanleiding tot een scene, waarin Juppiter haar van haar voornemen afbrengt en troostend verwisst naar Augustus, wiens wrekende pietas en zegennjke regeenng voorspeld worden. Deze scene is Ovidius' adaptatie van het bekende onderhoud tusschen deze zelfde goden in Aeness I Zooals daar Venus, door den wreeden storm, die Aeneas in het gezicht van Italie uit den koers sloeg, in haar geloof aan ziln zending geschokt, tot den almachtigen vader komt om opbeunng en opheldenng, waarop deze haar geruststelt en ter bemoediging een beeld ontwerpt van de toekomstige heerschappij, dat in de aanzegging van Augustus' regeenng culmineert, - zoo troost, na zooveel eeuwen, op het moment, dat de moord op Julus' afstammeling plaats vindt, op den drempel van den nieuwen gouden tyjd, dezelfde Juppiter een laatste maal (et referam, ne sis etiamnum ignara futun, 815, verwist duidelijk naar de Aene1s) de vertwifelde godin door te wizzen op de aanstaande regeenng van Augustus. Naast deze algemeene overeenkomst echter staan treffende verschllen. De majesteit, waarmede Verglius Juppiter bekleedt, is onovertroffen Venus spreekt hem aan met - qui res hominumque deumque Aeternis regis imperis et fulmine terres $229 \mathrm{v}$ ), en haar antwoordt de hominum sator atque deorum (254) $B_{1 j}$ Ovidius kalmeert de genitor zijn nata $(807 \mathrm{v})$; net de officieele kwaliteiten, doch de famliebetrekkingen worden genoemd, zooals in de apotheose van Aeneas en in de „elegische" versie der apotheose van Romulus : vermenschelyjung Voorts is er een sterk staal van moderniseering. Terwil Vergilius het beeld gebruikt van het ontrollen van de boekrol met de fatorum arcana (262), verwisst de Ovidiaansche Juppiter Venus naar het "hemelsch archief" (R 1 b beck p 311), dat hij - ten gerieve van den lezer - even beschrıft : een geweldig bouwwerk, waar de acten 
in brons en ijzer geboekstaafd zijn, onvergankelijk (808 vv.); zooals de materialen van Sol's paleis de schittering van de zon verbeelden, zoo beelden de materialen van het hemelsch archief de ijzeren onverbiddelijkheid van de besluiten der Parcen uit. Venus kan hier, in de betreffende afdeeling, de fata generis Veneris naslaan, welke op onvergankelijk staal gegrift zijn. Juppiter, die dit archief natuurlijk vlijtig consulteert, heeft het dossier nagelezen en refereert het voor haar. Deze vermetele moderniseering is een waardige aanvulling van de beschrijving van Godenstad in boek I. Ook hier geven de herinneringen aan Vergilius aan de moderniseering relief. Aan het eind van zijn verklaring geeft Juppiter Venus verlof om Caesar's ziel in een ster te veranderen, ut semper Capitolia nostra forumque Divus ab excelsa prospectet Iulius aede (841 v.), verwijzend naar den officieelen titel en den tempel van den vergoddelijkte: Aedes Divi Iulii, in het jaar 29 gedediceerd (W is s ow a R. K. p. 343 n. 1).

Door Venus snel hemelwaarts gevoerd, vat Caesar's ziel vlam en vliegt opwaarts hooger dan den kring der maan, luna altior (848). Het schijnt, dat in de "Arsione" van Callimachus iets dergelijks van Arsione's ziel gezegd werd:

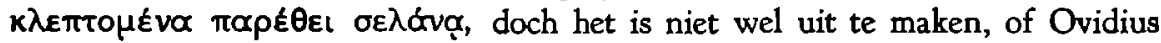
deze passage van zijn voorbeeld in de hofpoëzie voor oogen heeft gehad ( $P f$ e if $f$ e r p. 6). Ovidius zinspeelt ook op de in Rome zeer bekende en populaire Stoische theorie (Cic. Tusc. Disp. 1.19.23 en Somnium Scipionis), dat de groote, verdienstelijke zielen zich als sterren in de maanstreek verzamelen, terwijl daar-boven de woonplaats is der goden : altius aetherii quam candet circulus orbis. Illa deis sedes: haec illis, proxima divum $2 u$ virtute sua similes vestigia tangunt (Manil. 1.802 vv.). Volgens Lucanus (9.5 vv.) wonen de semidei manes daar, waar de aer en de axes astriferi aan elkaar raken; de laagste circulus astrifer nu is die der maan. Tertullianus (de anim. 54) geeft als plaats sub lunam, Servius (ad Aen. 5.735) circa lunarem circulum, ubi iam aer purior est. Luna altior schijnt dus te zeggen, dat Caesar een god werd, en meer dan een semideus. Een verwijzing naar deze populaire opvatting kon Ovidius zich niet ontzeggen; hij heeft haar verbonden met het persoonlijk ingrijpen der goden. Maar het godenapparaat, dat hij in heel de vertelling gebruikt had, kon hij op het beslissende moment niet overboord zetten. Wrijving is het gevolg: immers, of wel streeft de ziel door zelfwerkzaamheid, krachtens haar verdiensten, naar haar hooge bestemming, ofwel, als zij de hulp der goden noodig heeft, pleit dit niet voor haar kwaliteit. Ovidius redt zich hier, zooals elders, door een gelegenheidsmotiveering : nec in aera solvi Passa recentem animam (845 v.), ofschoon dit, op den keper beschouwd, geen compliment beteekent voor Caesar's verdienstelijkheid; daaraan verandert recens niets. Het woord draait ons even een rad voor de oogen, het geeft een schijn van rechtvaardiging voor het irgrijpen van Venus; dat is voor Ovidius genoeg. Het gaat trouwens te snel om tot bezinning te komen. Vage woorden doen de rest. De ziel, in hemelsche sferen beland, ontgloeit, en Venus laat haar los. Ovidius verblindt ons letterlijk door vuurwerk : de baan der opglanzende ziel-ster wordt met buitengewone plastiek beschreven : flammiferumque trahens spatioso limite crinem Stella micat (849 v.). Het is de beschrijving van Caesar's comeet, die tijdens de spelen voor Venus Genetrix, niet lang na Caesar's dood 
door Augustus gegeven, opvallend schitterde. Plinius spreekt erover en citeert daarbij Augustus zelf (2.93 v.) : Ipsis ludorum meorum diebus sidus crinitum per septem dies in regione caeli sub septemtrionibus est conspectum. id oriebatur circa undecimam horam diei clarumque et omnibus e terris conspicuum fuit. eo sidere significari vulgus credidit Caesaris animam inter deorum immortalium numina receptam, quo nomine id insigne simulacro capitis eius, quod mox in foro consecravimus, adiectum est. Op dit voorval, op den comeet en op de ster, aangebracht op het voorhoofd van Caesar's standbeeld, zinspeelt Ovidius hier dus, die ook in den aanvang reeds gesproken had van sidus - novum stellam. que comantem (749). Het verhaal eindigt met den lof van Augustus.

Zooals Callimachus het voorval van Berenice's haarlok in een hoofsche elegie had behandeld (vertaling bij Catullus 66), zoo werkt hier Ovidius een eigentijdsch gegeven op hoofsche wijze uit. Callimachus maakte van een bekoorlijk intermezzo een charmant capricio, Ovidius van een belangrijke gebeurtenis in de politiek een schetterende fanfare. Bij Callimachus spel en scherts met een inslag van ernst en hulde; bij Ovidius ernst en hulde met een inslag van spel en scherts; want ofschoon het thema verheven is, legt hij zijn esprit niet geheel het zwijgen op en blijft zijn principes getrouw. Wel zingt hij van Caesar en Venus Genetrix, wel herinnert hij aan Vergilius, maar hij aarzelt niet de banier der moderne kunstrichting te planten tot op den Palatijn : laudamus veteres, sed nostris utimur annis. 


\section{CONCLUSIE}

In de inleiding is uiteengezet, dat, aan den eenen kant, Ovidius de voltooier is van het alexandrinisme te Rome, en dat, aan den anderen kant, de alexan drijnsche godenschildering vooral gekenmerkt wordt door vermenschelijking, moderniseering, het spel met de dupliciteit van eponyme godheden en humor en ironie. Na de bespreking der afzonderlijke verhalen rest thans, in een samenvattend betoog, de Ovidiaansche godenschildering met de alexandrijnsche te confronteeren. Daarbij dienen de volgende vragen beantwoord te worden, of en in hoeverre in Ovidius' godenschildering dezelfde eigenaardigheden gevonden worden als in de alexandrijnsche, of wij bij hem werkelijk van principes, en niet slechts van sleur mogen spreken, in welke verhouding hij tot de alexandrijnsche dichters staat, of hij zelfstandig is in het realiseeren van zijn principes, en wat het specifiek eigene is van Ovidius.

\section{Vermenschelijking.}

Dat Ovidius zijn goden en godinnen in gedachten, woorden en werken als ware menschen teekent, treedt allerwegen aan het licht. Aan de goden is niets menschelijks vreemd; in het algemeen gedragen zij zich allesbehalve verheven en waardig. Van de menschen bezitten zij alle, kleinzielige vooral, soms ook beminnelijke, doch in goden steeds vermakelijke zwakheden. Men kan, als men wil, een opsomming geven van alle gevallen van echt menschelijk gedrag der goden, - Sol nukkig („Phaethon”), Apollo snoevend („Daphne”), Mercurius gewiekst („Battus”), Proserpina naief („Raptus Proserpinae”), Arethusa keuvelgraag (,Arethusa"), Diana onnoozel („Callisto"), Pallas onbeheerscht („Arachne”), Pomona preutsch („Pomona"), Latona klagerig (,Niobe”), Circe wulpsch („Circe”), Quirinus en Hora teeder minnend (,Apotheosis Romuli"), Juno rancuneus, Juppiter amoureus -, doch talrijke gevallen verdienen eerder een plaats onder de bespreking der moderniseering, en liever dan met een bloote opsomming te volstaan, willen wij enkele bijzondere gezichtspunten nader beschouwen, om aan te toonen, dat Ovidius de goden welbewust en systematisch vermenschelijkt.

Bespreken wij in de eerste plaats de ira deorum. De wrake der goden wil niet voldoening geven aan de geschonden goddelijke majesteit, doch aan de gekwetste ijdelheid en moet hun egoisme bevredigen. Uit gedeerde preutschheid, die in bloeddorst ontaardt, laat Diana den getuige harer naaktheid, Actaeon, een wreed einde vinden (,Actaeon"). Uit gekrenkte ijdelheid ook schiet zij Chione neer, die op het gelaat der godin kritiek had uitgeoefend ("Chione"). Hoezeer 
bij Pallas' wraak op Aglauros persoonlijke motieven in het spel zijn, blijkt uit de diepe zuchten, die zij slaakt, en uit haar verbeten opdracht aan Invidia („Herse"). Door het onbetwistbaar succes harer rivale, Arachne, en door de tergend godslasterlijke tafereelen, door deze op doek gebracht, geraakt Pallas in zulk een staat van opwinding, dat zij Arachne afrost en het doek onbeheerscht verscheurt (,Arachne"). Bevend van verontwaardiging om den smaad haar toegevoegd, met trillende stem, wenscht Latona (zij stoot eerder een verwensching uit dan dat zij een bevel geeft), dat Niobe's woorden niet zoozeer geboet en gewroken als wel aan de arrogante betaald gezet zullen worden („Niobe"). Ook de Lycische boeren verwenscht zij, ten uiterste getergd, meer dan dat zij hun een goddelijk wraakgericht overzendt (,Lycii coloni"). In onbesuisde drift schiet Phoebus de ontrouwe Coronis neer ("Coronis"). Synoniem met wreedheid, benepenheid, rancune en valsch gestook is de naam Juno („Callisto", „Lis iocosa”, „Ino”, „Semele"). Op krenkingen hunner ijdelheid reageeren de goden scherper dan een seismograaf : gravius iusto, zooals de dichter in "Lis iocosa" onomwonden constateert.

Groot is ook der goden egoisme, en op hun eeregaven zijn zij meer dan gesteld. Als Juppiter de verdelging van het menschelijk geslacht voorstelt, rijst de klemmende vraag, wie dan den goden wierook zal offeren (,Concilium deorum"). Wat, in de Fasti, Flora den dichter met ontwapenende oprechtheid bekent, nl. nos quoque tangit honor. festis gaudemus et aris, Turbaque caelestes ambitiosa sumus, geldt van de goden der Metamorphosen evenzeer : ook bij hen, als zij zich gekrenkt gevoelen, iustum praeterit ira modum. Als zij hun ambitiosus honor niet krijgen, als zij sine ture blijven, tangit et ira deos: zij staan er niet boven. Omdat zij sine ture gebleven was, zendt Diana den Calydoniërs een verderflijk everzwijn over. Achelous ontveinst zich niet, dat de menschen zich verbazen over zulk een wraak („Calydonius aper"). De ira deorum beteekent dus meestal een oogenblikkelijk toegeven aan primitieve driften, waaraan toe te geven den mensch niet tot eere strekt. Slechts hierin onderscheiden zich de goden van de menschen, dat zij niet slechts de neiging, doch ook de macht hebben om hun wraak uit te leven, hetgeen zij dan ook prompt en volkomen doen.

Bedenken wij daarbij, dat Ovidius niet gedwongen was door de sagen om den goden zulke onwaardige, kleinmenschelijke motieven toe te dichten. Integendeel, motieven van edeler aard, die in de lijn der verwachting lagen of die hij in de sage aantrof, verzwijgt hij vaak voorbedachtelijk, terwijl hij daarentegen onze deernis of bewondering opwekt voor de slachtoffers. In „Actaeon" bijv. had de dichter zich voor de straf kunnen beroepen op goddelijke wetten, zooals bij Callimachus in het „Bad van Pallas” Athene dit doet; hij had ook de straf automatisch kunnen laten volgen, zonder een woord of gebaar der godin; Actaeon daarentegen had een vuige belager kunnen zijn harer maagdelijke ongereptheid. Ovidius gaat echter in juist tegenovergestelde richting. Over de onschuld van Actaeon, slachtoffer van een jammerlijken samenloop van omstandigheden, laat hij geen twijfel bestaan, doch hij insisteert op Diana's preutschheid en wraakgevoelens en onverzadigbare wreedheid, zoodat men, met een deel der goden, aan de billijkheid der straf, die in feite wraakneming is, twijfelen 
kan Een ander voorbeeld: de sage dwong den dichter stellig nuet om op te merken, zooals hij niet zonder emphase doet, dat Arachne's werkstuk buiten kyf meesterlijk was, dat de prestatie der godin die der stervelinge, om het welwillend te formuleeren, niet in de schaduw stelde; en had niet eigenlijk in dezen wedkamp tusschen een sterveling en een godheid voor de godin een supeneure houding beter gepast dan de anımositeit, die zij tıdens en na het weven verraadt? (,Arachne”). In „N1obe" wordt niet Latona majesteitelijk geschilderd, toornend en gebredend, doch wel de zondares Niobe, indrukwekkende persoonlijkherd, grootsch tot in haar overmoed, waardig goddelijk genoemd te worden, als zij het met zelf verlangde.

$\mathrm{B}_{1 j}$ de schildering van de ira deorum dicht Ovidus den goden dus de laagste motieven toe, en hy doet dit niet, daartoe gedwongen door de sagen, maar vriywillig en welbewust, de sagen naar eigen hand zettend, terwijl hij de kleinzieligheid der wraak niet enkel laat doorschemeren, doch soms ook duidelijk uitspreekt.

Wulpschherd en een vaak cynisch egorsme kenmerken vooral de liefdesavonturen

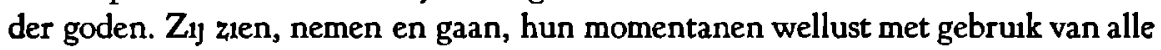
machtsmiddelen uitlevend zonder eenige consideratie voor hun slachtoffers. Geen plaats is voor de schoonen der aarde veilig Het bosch is Callisto noodlottig ; in het bosch ook wil Juppiter de nymph Io lokken Aan het strand wordt Europa weggelokt; aan het strand ontkomt Coroneus' dochter slechts door het verlies harer menschelyke gedaante, valt Caenus ten proor aan Neptunus' begeerte. In haar slaapkamer wordt Leucothoe verrast Herse wekt Mercurus' hartstocht b1] een plechtige processie Pallas ter eere. Medusa wordt door Neptunus zelfs verkracht in den tempel der maagdelijke Munerva. Het lijkt wel een echo van Ovidius' verhalen, als by Nonnus een launernymph, beducht voor het verlies harer maagdelijkheid, zich jammerend afvraagt, waarheen te vluchten, nergens 1s zij vellig ; de rotsen hernneren haar aan Pan's slachtoffers, de bergen aan de arme Callisto, het strand der zee wordt door Poseidon onvellig gemaakt (2. 113 vv.). Ook misbruken de goden hun goddelijke macht om hun lusten zoo snel mogelijk bot te vieren Bedrog en geweld zijn niet van de lucht Wel wijst Io haar goddelyken verleider af en vlucht heen, maar dra maakt hy door een dikken nevel haar het vluchten onmogelık, rapuitque pudorem. Hun vermommingen zijn vaak perfied. Wanneer Juppiter wellustig Callisto aanrandt, heeft hij de gestalte aangenomen van haar meesteres, de kusche Diana, aan wie zij eeuwige maagdelijkhe1d gezworen heeft De kinderlıke Europa wordt door een stier weggemanoeuvreerd van vriendinnen en vaderland Als haar moeder vermomd, dringt Sol tot Leucothoe's vertrek door, waarut deze moeder voor een onderhoud onder vier oogen de dienaressen wegzendt $O_{p}$ alle mogelijke wizzen tracht de duizendkunstenaar Vertumnus tot Pomona door te dringen, wat hem tenslotte gelukt in de gedaante van een oude bes. De kroon van al deze ondernemungen spant evenwel het voorval met Chione, een jeugdige schoonheid, die binnen het bestek van enkele uren in de armen rust van twee goden, welke haar toevallig hadden opgemerkt: Mercurius, geen uitstel verdragend, handelt op stel en sprong : geen onderhandelingen, hy bedwelmt het meisje eenvoudigweg 
met zijn tooverstaf; des nachts komt dan nog Apollo, vermomd als oude vrouw, en smaakt de praerepta gaudia.

Hoezeer de Ovidiaansche goden opgaan in het najagen van hun particuliere genoegens, demonstreert zeer goed de activiteit van Mercurius, der goden boodschapper. Van officieele apdrachten in den godenraad hooren wij niet, wel echter van particuliere, en zelfs geheime opdrachten door Juppiter. Hem wordt bijv. opgedragen Argus te dooden, Io's lastigen bewaker. Zijn dagen zijn zeer bezet : nauwelijks van den diefstal van Apollo's runderen, en van zijn en route waargenomen amourette met Herse op den Olympus teruggekeerd, wordt hij door Juppiter conspiratorisch terzijde genomen en krijgt, zonder verdere opgave van redenen, de opdracht Agenor's kudde naar het strand te drijven : Europa is aan de beurt. Onwillekeurig komt den lezer hier voor den geest Lucianus' dialoog tusschen Hermes en Maia, waarin Hermes, afgemat, zijn leed klaagt : bij alles, wat hij in den hemel te doen heeft, moet hij ook nog voortdurend met bijzondere opdrachten naar de aarde: nauwelijks van Sidon terug, waar hij moest kijken, waarmede Europa zich bezighield, moet hij, zonder nog op adem gekomen te zijn, alweer naar Argos, wegens Danae, en vandaar naar Boeotië, om meteen even een blik te werpen op Antiope; Hermes is dit jachterig leven moe, en zou graag, als een slaaf, die een kwaden meester heeft, van heer veranderen (dial. deor. 24).

De vraag kan gesteld worden, of niet de sagen, die toch in groote lijnen vaststonden, voor den boven geschilderden indruk verantwoordelijk zijn en of niet de constipatie van zoovele bedenkelijke avonturen aan de eigenaardige compositie der Metamorphosen geweten moet worden. In het eerste boek bijv. worden drie liefdesverhalen onmiddellijk achter elkaar verteld : wil de dichter hiermede te kennen geven, dat de goden in hun liefdesavonturen opgaan, of is het niet beter, aan te nemen, dat hij zijn kunst van verweving en variatie heeft willen toonen juist daar, waar het gevaar van monotonie zeer groot was? Toegegeven dus den feitelijken indruk, dien de verhalen maken, is het ook Ovidius' opzet om dezen indruk te wekken? Een nadere beschouwing der liefdesverhalen zal ons het antwoord geven.

Het vaak cynisch eenvoudige proces eener godenliefde wordt in de Fasti aldus in één enkel vers samengevat : Mars videt hanc visamque cupit potiturque cupita (3. 21). De fatale afloop van menige achtervolging vat, in de Fasti, Flora aldus samen in een bewonderenswaardig distichon: ver erat, errabam: Zephyrus conspexit, abibam, Insequitur, fugio: fortior ille fuit (5.201 v.). Dergelijke "stunts" nu komen in de Metamorphosen niet voor, hetgeen ons ook niet behoeft te verwonderen, daar het ondanks alles episch karakter van dit werk een zekere gelijkmatigheid eischt en te groote grilligheid niet toestaat. Wel vinden wij sommige liefdes en achtervolgingen in zulk een geraffineerd eenvoudigen stijl gesteld, dat zij, in episch verband, de boven geciteerde opmerkingen uit de Fasti in waarde evenaren en evenzeer vingerwijzingen zijn voor het cynisch egoisme der goden. De schijnbaar achtelooze wijze, waarop van Chione verteld wordt, ars casu similis, is in feite uiterst berekende ars dissimulata; de zakelijkheid ervan is vernietigend. Vernietigend is de zakelijk refereerende toon, waarin de 
opsomming der liefdesavonturen en der vermommingen gehouden wordt bij de beschrijving van Arachne's weefsel. Verschillende malen vertellen de slachtoffers zelve haar belevenissen. Treffend in haar soberheid vertelt Coroneus' dochter : vidit et incaluit pelagi deus, utque precando Tempora cum blandis absumpsit inania verbis, Vim parat et sequitur; fugio etc. (2. $574 \mathrm{vv}$.). Ovidius maakt een gelukkig gebruik van de omstandigheid, dat soms de avonturen door de goden zelf verteld worden. Arethusa constateert openhartig: sicut eram, fugio sine vestibus (altera vestes Ripa meas habuit). tanto magis instat et ardet Et, quia nuda fui, sum visa paratior illi. Ook verlicht soms een enkel woord als een bliksemstraal de gansche situatie: Juppiter ziet Callisto, volgt een kort beraad, en protinus neemt hij zijn vermomming aan. Forma mihi nocuit: met deze drie woorden vat de dochter van Coroneus haar noodlot samen; van vele andere schoonen kan hetzelfde gezegd worden : placuisse nocet. De dichter laat dus door zijn wijze van voorstellen de feiten een nog krachtiger taal spreken dan zij op zich reeds doen. Wanneer hij den feitelijken indruk, dien de verhalen maken, niet gewild had, zou hij de feiten, waaraan hij niets kon veranderen, niet ontwikkeld hebben op zulk een wijze.

In de Fasti levert de dichter op de verkrachting van Callisto (doch zijn woorden zijn niet alleen op Callisto van toepasssing), dezen commentaar: Foedera servasset, si non formosa fuisset: Cavit mortales, de Iove crimen habet (2. 161 v.). Zelfs in de epische Metamorphosen levert de dichter eens direct commentaar, waar hij namelijk, naar aanleiding van Daphne's wensch om steeds maagd te blijven, de schoone apostropheerend, opmerkt : sed te decor iste, quod optas, Esse votoque tuo tua forma repugnat. Hier zegt hij dus zelf, de dichter, wat hij met forma mihi nocuit een slachtoffer laat zeggen. Aan deze opmerking moet des te meer waarde worden toegekend, daar zij staat bij den aanvang van het eerste liefdesverhaal : exemplarisch.

Ook steekt Ovidius de wulpschheid der goden niet onder stoelen of banken. Op het zien van Callisto, als het spookbeeld der wrekende Juno voor Juppiter's geest opdoemt, roept de beluste dra uit : sunt, o sunt iurgia tanti; het kon niet levendiger. Nog heeft Callisto haar vermeende meesteres nauwelijks begroet, of Juppiter kust haar, en deze kussen worden fijntjes gekwalificeerd als nec moderata satis nec sic a virgine danda. 2ualia numquam Vera dedisset anus, zijn de kussen, die Vertumnus als een oud besje aan Pomona geeft. Als Europa den vriendelijken stier bloemen toereikt, kust de belager haar handen : vix iam, vix cetera differt; ook hier moet men zeggen: het kon niet levendiger en emphatischer. Tweemaal in twee opeenvolgende verzen neemt Ovidius, die waarachtig wel de kunst van varieeren verstond, het woord avidus in den mond, als hij beschrijft, hoe Mercurius boven de Atheensche schoonen rondcirkelt, zijn tijd beidend, - gelijk een roofvogel boven een offerande op het altaar, - treffende vergelijking (,Herse").

Ook over de talrijkheid der godenliefdes, van die van Juppiter in het bijzonder, laat de dichter geen twijfel bestaan. Bij den aanvang van Juppiter's eerste escapade, die beschreven wordt, - exemplarisch - licht de schermutseling tusschen Juno en haar gemaal ons in èn omtrent den aard der hemelkoningin, waaksch als 
een jachthond, èn omtrent den oppergod zelf : atque, suus coniunx ubi sit, carcumspicit, ut quae Deprensi totiens zam nosset furta manti („Io") Het veelzeggende woord totiens gebrukt Juno nog een andere maal . profect quid entm totiens per iurgia? („Semele") En elders, eveneens in verband met Juno's waakzaamhe1d, gebruikt de dichter zelf het woord saepe - cum deprendere posset Sub Iove saepe suo nymphas in monte racentes ("Echo") Ovidius wekt dus niet slechts in feite, doch ook met opzet den indruk, dat de liefdesavonturen der wulpsche hemelingen talrijk zijn $\mathrm{H}_{1 j}$ is bly, dat hij aan de Grieksche op eigen gezag nog een Latınsche godenliefde kan toevoegen („Pomona”) Toch was de dichter niet gedwongen op deze en dergelije wijzen den vinger te leggen op de willekeur, of den acuten of groeienden wellust der goden, of de talnjkheid hunner liefdes. De aangestıpte gevallen staan dan ook gelıjk met even zoovele verklaringen van den dichter omtrent den aard der goden wat wij zakelijk formuleeren, suggereert hij op zijn eigen, dichterlijke wijze $\mathrm{H}_{1 j}$ heeft het niet vermeden, noch ook trachten of willen vermijden, hij heeft, integendeel, de gelegenherd gretig aangegrepen om, naar het woord van Propertius, canere antiqui dulcia furta Iovis, Ut Semela est combustus, ut est deperditus Io, Denique ut ad Troiae tecte volart avis (2. $30.28 \mathrm{vv}$ ). Het vers uit Vergilius' Georgica (4.347) aque Chao densos divom numerabat amores is als voor den dichter der Metamorphosen geschreven $\mathrm{Na}$ in de eerste vif boeken er talnjke verhaald te hebben, gaat Ovidius in de beschrijving van Arachne's weefsel, als bekroning en samenvatting der voorafgaande boeken, zelfs tot een formeele opsomming over. Het aantal gevallen is daarbij op zichzelf reeds indrukwekkend, doch de berekend zakelijke stijl suggereert ons een eindelooze reeks Merk hierbij op, dat Ovidius niet enkel een opsomming geeft, doch tevens naar hun erotische capaciteit de juste rangorde der onderscheidene heeren

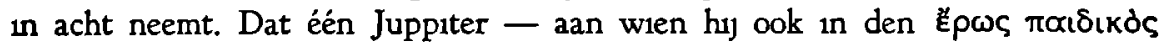
de eereplaats toekent (,Ganymedes") - ook in rebus eroticis tegen alle ovenge goden opweegt, toont de dichter door de gansche eerste helft der opsomming zinruk te reserveeren voor de escapades van den oppergod, daarop neemt Neptunus - Neptunus fratn par in amore Iovı - een zeer eervolle tweede plaats in, propior tamen primo quam tertio (cf. Quint 10186 ), hierop volgen vertegenwoordigers der overige goden.

En tenslotte, dat hij niet toevallig voornamelijk liefdesavonturen der goden verhaalt, geeft de dichter tot tweemaal toe te verstaan door aan te duden, dat hun leven in het teeken van Amor staat, dat deze de eigenlyke machthebber is $B_{1 j}$ den aanvang van het eerste liefdesverhaal - exemplansch - lijdt Apollo de nederlaag tegen het dartele ventje met den geduchten boog, waarvoor allen moeten zwichten ("Daphne") Later neemt de dichter de gelegenheid te baat om ook Venus in de heerschappij te betrekken, en ontwerpt zoo, schertsend doch cum fundamento in re, een beeld van de dyarche over hemel en aarde zoowel als onderwereld van Venus als politica en Amor als de gewapende macht („Raptus Proserpinae") Op epische wijze, vertellend, geeft de dichter aldus in de Metamorphosen hetzelfde te kennen, wat hy elders met even zoovele woorden van Amor constateert . regnat et in dominos ius habet ille deos ("Daphne").

De meeste verhalen, die Ovidius van de goden vertelt, betreffen particuliere 
aangelegenheden, die met hun officieele functies niets uitstaande hebben, waarin hun gedragingen echter vaak in scherpe tegenstelling staan tot de goddelijke hoogheid. De dichter constateert of suggereert dit zelf meer dan eens. Non bene conveniunt nec in una sede morantur Maiestas et amor: sceptri gravitate relicta Ille pater rectorque deum, cui dextra trisulcis Ignibus armata est, qui nutu concutit orbem, - Induitur faciem tauri etc. („Europa"). Door de liefde overmeesterd, bekreunen zich noch Apollo noch Venus meer om hun cultusplaatsen (,Admetus", „Hyacinthus", „Adonis") ; vergeefs raadpleegt men te Delphi het orakel : de god zit in herderskleedij droomerig te pijpen, of torst, immemor ipse sui, voor den geliefden knaap den last der netten. Aan wie valt Chione ten prooi ? aan een Apollo, die van Delphi, aan een Mercurius, die van den Cyllenetop komt : goddelijke hoogheid en menschelijke laagheid, het is slechts één pas.

Laat ons echter, tot slot, nagaan, hoe de goden geschilderd worden in aangelegenheden van officieelen aard. Ook hierin worden zij als echte menschen geteekend, vol van hun particuliere belangen en genoegens. Op de familiebetrekkingen der goden wordt opvallend sterk geinsisteerd. Het initiatief tot den dood van Achilles gaat uit van Neptunus, die plus quam civiliter wrokt op dezen held, omdat hij 's goden zoon Cygnus in den strijd bedwongen heeft (men herinnere zich ook het nukkig mokken van Sol om den dood van Phaethon). Neptunus wendt zich tot Apollo, dien hij noemt den ,verreweg meest dierbaren zoon zijns broeders", en Apollo sluit zich bij hem aan om persoonlijke redenen en ter wille van zijn oom. Terwijl de dichter zelf van deze goden in sterk Homeriseerende wendingen spreekt, laat hij de goden met hun familierelaties werken. Bij den zondvloed komt niet de heerscher der wateren den heerscher van hemel en aarde te hulp, een voorstelling van zaken, die men in de omstandigheden verwachten mocht, temeer daar Neptunus als bevelhebber der hulptroepen geteekend wordt, doch krijgt Juppiter steun van zijn broeder. In „Mors Achillis" kan men wijzen op hetzelfde verschijnsel bij Homerus ; in "Diluvium" zou men van een toeval kunnen spreken; doch bij het volgende is dat niet het geval. Venus, in een episch gestyleerd verhaal, vraagt aan Neptunus de vergoddelijking van Ino. Door woordelijke overeenkomsten worden wij herinnerd aan de interventie van dezelfde godin bij denzelfden god in het vijfde boek der Aeneis. Doch er is een groot contrast: verzoekt Venus bij Vergilius de medewerking van den "zoon van Saturnus, bedwinger der diepe zee", met een beroep op Aeneas' goddelijke zending, bij Ovidius daarentegen vraagt zij vleiend aan haar oom om de vergoddelijking harer kleindochter als een persoonlijke gunst. In opzettelijke tegenstelling tot de hoogere epiek, zooals het gezochte contrast met den grootmeester Vergilius bewijst, dicht Ovidius in deze gevallen den goden geen hoogere motieven toe, doch laat het persoonlijke moment scherp uitkomen, voornamelijk door het motief der familiebetrekkingen.

Treffender nog zijn de volgende verhalen. Bij de apotheose van Aeneas smeekt Venus, verwend en eerzuchtig, haar almachtigen papa, de armen om zijn hals slaande, om ditmaal zijn heel speciale gunst, om een goddelijkheid, zij het ook nog zulk een kleine, als het er maar een is, voor haar zoon. Daarbij doet zij geen beroep op Aeneas' verdiensten of deugd, doch op de gunst van grootvader, 
en vader Juppiter geeft zijn dochter haar zin : een beslissende godenraad over het toekennen der goddelijkheid wordt tot een huiselijke scene, een particuliere aangelegenheid. Bij de apotheose van Caesar is zij andermaal de verwende dochter, mateloos klagend, en de vader tracht zijn dochter te kalmeeren. Indien ergens, dan was er in deze verhalen alle reden om de officieele kwaliteiten der goden te belichten. De toekenning der apotheose is een bij uitstek officieele aangelegenheid. Ook betreft het niet enkele willekeurige personen uit de Grieksche mythologie, doch figuren van groote nationale en dynastieke importantie. Daarbij komt, dat deze verhalen in zekeren zin een aanvulling zijn van het nationale epos, de Aeneis. Onkunde van de zijde des dichters is ten eenenmale uitgesloten : Ovidius bewijst in beide verhalen, dat hij vertrouwd was met de Vergiliaansche motieven en gedachtenwereld. Uitgesloten is ook onmacht des dichters om deze onderwerpen in een officieel kleed te steken, om, bij wijze van spreken, een versio togata te geven en niet tunicata : dit bewijzen zoowel andere verhalen (waarover wij nog zullen spreken) als ook in "Aeneae apotheosis" de diplomatieke inkleeding van Aeneas' verdrinkingsdood, welke als een van hooger hand bevolen lustratie wordt voorgesteld. Desalniettemin schildert Ovidius ook hier, in zaken van wereldhistorische importantie, de goden als particuliere personen, als familieleden, vervuld van hun eigen persoonlijke belangen, niet als wereldbestierders, en hij doet dit, zooals de vrijwillig opgeroepen contrasten bewijzen, welbewust, principieel.

De uitzonderingen op dezen regel bevestigen den regel zoo mogelijk nog onbetwijfelbaarder. Uitzonderingen zijn de volgende verhalen : „Raptus Proserpinae”, "Herculis apotheosis”, „Sabini repulsi”, „Romuli apotheosis", „Aesculapius".

Van den „Raptus Proserpinae” staat de versie der Metamorphosen tegenover die der Fasti ; in de Metamorphosen rooft zich de beheerscher der Onderwereld een gemalin, in de Fasti wordt Proserpina geschaakt door haar oom. In „Herculis apotheosis" is de dichter van zijn gewoonte afgeweken en tot epische plechtstatigheid overgegaan, niet uit poëtische, doch uit adulatorische overwegingen, omdat hij, zooals hij door het woord augustus te kennen geeft, in Hercules' apotheose naar de gebruikelijke opvattingen een voorafbeelding ziet van Augustus' toekomstige belooning en heerlijkheid. In "Sabini repulsi" is een elegische nevenversie in de Fasti de reden, dat in de Metamorphosen naar hoog-epische traditie Venus als de beschermster, Juno daarentegen als de tegenstandster van den Romeinschen staat wordt voorgesteld. De inhaling van "Aesculapius” is de epische tegenhanger van de elegisch gestyleerde inhaling der Magna Mater in de Fasti, in welk laatste verhaal wij weer de vermelding der familierelaties opmerken. Het kostelijkst bewijsstuk evenwel voor den regel, hierboven gegeven, levert de uitzondering „Romuli apotheosis". Ook van dit verhaal heeft Ovidius èn in de Metamorphosen èn in de Fasti een versie gegeven. Had de dichter zich niet vrijwillig gedwongen in de Metamorphosen tot een hoog-epische versie, ongetwijfeld zou, in den geest van "Aeneae apotheosis", Mars als vader van Romulus aan zijn vader Juppiter de apotheose gevraagd hebben voor zijn zoon als een persoonlijke gunst. Dit nu is juist de versie der Fasti, waarmede die der 
Metamorphosen in volslagen contrast staat, dat $\mathrm{nl}$ Mars als beschermer van den Romeinschen staat, nu na het eerste moelijke begin Romulus net meer onmisbaar 15, voor den stichter van Rome aan den opperbestierder van hemel en aarde de vergoddelıking vraagt tot belooning zijner verdiensten. In de Fastie een zuivere famulieaangelegenhe1d, in de Metamorphosen nets dan wereldpolitiek Ovidius weet dus een officieele aangelegenherd der goden zeer wel in stijl te behandelen. Een enkele maal doet hij dit ook, als hy namelık zijn stylistisch kunnen naar verschillende zijden aan een en hetzelfde onderwerp wil toonen Waar hij zich echter niet onder vnjwilligen dwang stelt, volgt hij stelselmatig, noch uit onkunde noch ut onmacht, principieel dus, den stıl, door Heinze elegisch genoemd, waarbij de goden niet als de majesteitelijke wereldbestierders, doch als gewone particuliere personen worden geschilderd, geleid door beweegredenen van geheel persoonlıken aard, in alles gelıkend op den kleınen sterveling

En zoo ludt de slotconclusie : net slechts een enkele maal en bij toeval of noodgewongen, niet slechts in de verhalen van particuliere ondernemingen der goden, doch steeds en welbewust, ook daar waar men het tegendeel verwachten mocht, realiseert Ovidius het principe der vermenschelijkng, en deze vermenschelijkıng beteekent nuet een schldenng der goden naar de edelsten van het sterfely]k geslacht, doch bij voorkeur een schuldering naar der menschen zwakke zijden. Eerder dan rets menschelijks is den goden alle goddelıks vreemd .

Typeerend voor de Ovidiaansche goden is de "Turbida Seditio" van het negende boek, een eigen fantasie des dichters, althans in den samenhang, waarn 2ij bij hem voorkomt, en door geen dwang der situatie of compositie ingevoegd Dezelfde goden, die, bij een ver-strekkend besluit als de verdelging van het menschelıjk geslacht, zich voornamelijk over hun wierook bezorgd maken, doch ovengens den heerscher een gewillig gehoor strekken, worden tot verscheurende dieren en slaan aan het rebelleeren, als het gaat om het vergeven van voorrechten aan hun favoneten Alleen in zulk een geval doet de Ovidiaansche Juppiter pathetisch een beroep op de fata, terwijl slechts de verwijzing van den oppergod naar eigen husselyke misère de verhitte gemoederen kan bekoelen.

\section{Moderniseering.}

Tusschen vermenschelujking en moderniseenng wordt, zooals in de inleiding onder de besprekung der alexandnjnsche godenschildenng is opgemerkt, slechts overzichtelijkheidshalve onderscheiden Overal projecteert de dichter in de godenschildering zijn eigen tijd en omgeving. Waar ondubbelzinnige indicia zijn van 's dichters eigen tid, spreken wij van moderniseenng, waar wij net het specifiek eigentudsche, doch slechts het algemeen menschelijke ontmoeten, spreken wij van vermenschelyjking In twijfelgevallen moeten wy kiezen Circe wordt door Ovidus geschilderd als toovenares naar de opvattingen van zijn tijd, zooals die in het werk der elegiacı tot uitdrukkung komen Minerva en de Muzen geven blık van fyjne geestesbeschaving (een hulde aan de poezie); al kunnen wij geen bewijzen leveren, de indruk, dat Ovidius in haar de doctae, rarissima turba, puellae sch1dert, die aan corpons bonis paren ingenu dotes, is daarom niet munder sterk (,Musae"). 
Van de actualiteit in Ovidius' poezie, ook in de Metamorphosen, kunnen wis ons na zooveel eeuwen nog slechts een flauwe voorstelling vormen Het pathetisch vermaan tegen het vleeschgebruik, dat Ovidius Pythagoras in den mond legt, wordt door $R_{1 b}$ beck ( $310 \mathrm{v}$ ) in verband gebracht met de nieuwpythagoreische prediking van Sextius en Sotion in 's dichters tijd. Ehwald (ad 6. 169) vermoedt, dat Ovidius, evenals dat het geval is in het scheidsgerecht over Achilles' wapenen, in het schilderen van de houding van Niobe, als zil haar declamatie (want dat is het) gaat houden, gebruk gemaakt heeft van het acteeren van den declamator Porcius Latro Soms zien wij, soms vermoeden wiy; het is net utgesloten, dat, als ons de volledige feiten ter beschukking stonden, onze stoutste verwachtingen zouden overtroffen worden Tot welk een graad van moderniseenng Ovidius in de godenschildering durft te gaan, zullen wij aanstonds uiteenzetten Vooraf mogen enkele gevallen genoemd worden, waann de actueele noot onmiskenbaar is Het verhaal van Iphis, die van meisje jongen wordt, gaat op een verhaal van Nicander terug (,Iphis") Latona is hierin bij Ovidius vervangen door Isis; de reden moet wel gezocht worden in het fert, dat Ovidius minder belang stelde in de aetiologische opmerkingen, die aan het ingnjpen van Latona vastgeknoopt kunnen worden, dan in de populariteit, welke de Egyptische godin en haar exotische eeredienst te Rome speciaal bij de dames genoten. Verder maakt Ovidius in de godenschildering verschillende malen gebrulk van bekende beelden, waarbij door de toovermacht der poezie zich het wonder van Pygmalion herhaalt. De verrassing der tijdgenooten moet groot geweest zijn, toen zij het beroemde beeld van Apollo tot leven en beweging zagen komen („Coronis”, „Midas") De schldering van Amor, die zijn boog aan het spannen 1s, wekt ook allerles herinnernngen aan werken der plastiek (,Raptus Proserpinae") Volgens B a rtholomé is aan de schuldenng van den verbolgen Juppiter in "Concilium deorum" het cultusbeeld van Juppiter Tonans net vreemd. Dezelfde vermoedt, dat ook de Sol uit "Phaethon" naar een cultusbeeld geteekend is Heel duidelijk hernnert ons aan een cultusbeeld de beschrijving van Aesculapius Dat bij de beschrijving van Callope en de Muzen den tijdgenooten van Ovidius een bekende beeldengroep uit Rome voor den geest kwam, is nuet utgesloten (,Musae”). De schildering van het Muzenheim kon wel eens teruggaan op de popularre musaed te Rome. Het is meer dan waarschunlujk, dat ons in de godenschildening vele actueele en moderne noten ontgaan

Aan Rome herinneren ons de goden in menig opzicht Juppiter is doortrapt in de rhetonek („Concilium deorum”) Tellus („Phaethon”), Latona („Lyc11 coloni”) en Aurora („Aurora”) geven blyk van een niet gennge kennis der rhetorische kunstgrepen. Latona doet zelfs een beroep op het natuurrecht Apollo (,Hyacinthus") snujdt het interessante thema aan van onvrijwilligen doodslag Peneus spreekt recht over de golven en de nymphen, die de golven bewonen (1 575 v) De nymphen vormen in „Musae" een formeele jury van gezworenen. Ook in militair opzicht worden wij aan Rome herinnerd. Juppiter's bliksemschichten worden door de hemelingen onderscheiden in zwaarder en lichter geschut („Semele"). Lucifer is officier der hemelwacht („Phaethon”) Bij den zondvloed komt Neptunus zijn broeder steunen met zijn hulptroepen, ruitenj, die, na de gebruikelijke 
opwekking, attaqueert, doch, op het signaal van hoornblazer Triton, in volmaakte discipline terugtrekt. Ook de politiek ontbreekt niet. De godenraad is een formeele senaatszitting („Concilium deorum"). De archieven der Parcen, een imposant gebouw, worden door den opperbestierder vijtig bezocht (,Caesaris apotheosis").

Ook de paleizen der goden herinneren aan Rome. Sol's machtige regia, met haar hoogen opgang, haar zuilen en fastigium, haar relief-gesmukte deuren, is geinspireerd op den tempel van Apollo Palatinus („Phaethon"). Het huis van Circe, met zijn marmeren atrium en schoone binnenzaal, lijkt wel een moderne villa. De grot van Achelous verschilt slechts in materiaal (doch dit komt op rekening van de omstandigheid, dat hij riviergod is), niet in luxueuze bewerking van de paleizen der Romeinsche grande's. Het kostelijk tafelgerei doet niet onder voor dat van den verfijndsten Romein; ook ligt men bij het banquet aan op Romeinsche wijze („Convivium Acheloi”). Dat de luxe op den Olympus zelf niet minder groot is, bewijzen de valuae eburnae van Vulcanus' woning (,Mars et Venus"), terwijl in de Onderwereld Pluto's fraai verzorgde parken Proserpina tot kennismaking nooden (,Raptus Proserpinae"). Olympus en Onderwereld herinneren trouwens niet in een enkel onderdeel aan het Augusteïsch Rome, doch weerspiegelen dit in hun geheel. De opbouw en organisatie van het Hemelsche Rome komen geheel met die der metropolis overeen : op wat de dichter niet aarzelt Palatia caeli te noemen, resideert de heerscher; in de deftige wijken vervolgens zijn de nobiles gedomicilieerd; terwijl in verder afgelegen wijken de plebs een onderkomen vindt. In den morgen gonzen de atria der aanzienlijken van het stemmengeroes dergenen, die hun salutatio komen brengen (,Concilium deorum"). Een pendant van het Hemelsche Rome is het Rome der Onderwereld, een stad, deels vol leven en modern vertier, een eldorado voor den verwenden stedeling, deels een welgeorganiseerde gevangenis, waarin Cerberus ianitor is en de Erinyen cipiers („Ino").

Bij zooveel liefdesavonturen ontbreken natuurlijk de overeenkomsten niet met het leven van Rome's jonkheid ; allerwegen worden wij herinnerd aan de wereld der Amores en der Ars Amatoria. Aan Mercurius is het onderwijs der Ars niet verspild : niet alleen is hij ervan doordrongen, dat een feestelijke plechtigheid een der geschiktste gelegenheden is voor een flirtation, hij maakt ook, volgens de regelen der kunst, alvorens avances te doen, zorgvuldig toilet; doch ook hij blijft niet gespaard van de inhaligheid der tusschenpersonen, die het leven des minnaars vergallen („Herse”). Een typische vertegenwoordiger der jeunesse dorée is Apollo, wien, bij het zien der schoone, doch non culta Daphne, subit quid cultae accedere possit. Met weemoed denkt de oude Sibylle terug aan haar goede jaren, toen Apollo, als de dives amator der elegie, haar trachtte om te koopen met geschenken. In het verhaal van Coronis speelt dezelfde god de rol van den vir credulus der elegie, die, door zijn custos ingelicht omtrent (alleszins decente) ontrouw van zijn geliefde, meer onstuimig dan verstandig zijn wraak koelt. De dames blijven in modemiteit bij de heeren niet ten achter. Arethusa verwondert zich erover, dat er een tijd was, dat zij rustica was en het voor een zonde hield aantrekkelijk te zijn. Circe is naar de laatste mode gekleed. De behaagzieke 
Salmacis vereenigt alle voortreffelijkheden eener courtisane in zich. Scylla fungeert als coiffeuse van Galatea („Salmacis"), die haar tijdens het kappen, zooals Ovidius dit reeds in de Ars beschreven had, haar hartsgeheimen openbaart. Diana wordt bij het bad, dat plaats heeft in een kunstgrot, verzorgd door een staf van welgetrainde bedienden, onder welke de ornatrix niet de geringste is („Actaeon").

De moderniseering heeft dus plaats over de geheele lijn. Dit geschiedt te systematisch dan dat het niet weloverwogen en principieel zou geschieden. Dat Ovidius juist aan het begin der eigenlijke verhalen („Concilium deorum”) een uitvoerig beeld ontwerpt van het Hemelsch Rome, is geen toeval: de beschrijving is programmatisch. Daarbij komt, dat Ovidius niet slechts in feite, doch ook vaak welbewust in tegenstelling staat tot oudere auteurs. De afwijkingen van Homerus in de schildering van Circe's villa berusten niet op onkunde van Ovidius, die immers in hetzelfde verhaal in andere opzichten blijk geeft van een minutieuze kennis van den vader der epiek. In „Mars et Venus”, waarin Ovidius een referaat geeft van Demodocus' befaamden zang, staan de valvae eburnae tegenover het

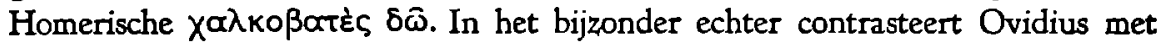
den coryphee der Romeinsche litteratuur, met Vergilius. De schildering van de archieven der Parcen vormt een weloverwogen moderniseering van Vergilius' eerbiedwaardig beeld van de boekrol der fata ("Caesaris apotheosis"). Vooral echter in de schildering van Olympus en Onderwereld wijkt hij van hem af; woordelijke overeenkomst herinneren aan zijn voorganger en onderstrepen bijaldien de groote, fundamenteele verschillen. Moderniseering is dus ook een principe der Ovidiaansche godenschildering, door den dichter met evenveel overtuiging als energie in toepassing gebracht.

Spel met de dupliciteit van eponyme godheden.

Bij geen ons behouden gebleven dichter vò̀r Ovidius zijn de schilderingen van personificaties zoo talrijk als bij hem. De talrijkheid ervan vindt ten deele haar verklaring in den omvang en den bonten inhoud der Metamorphosen. Met de talrijkheid gaat echter samen de uitvoerigheid der beschrijvingen; uitvoerige beschrijvingen vinden wij bijv. van Invidia (,Herse”), Fames („Erysichthon”), Fama („Fama”), Somnus (,Ceyx et Alcyone"). Vergilius' schildering van Fama is, vergeleken met de Ovidiaansche van Invidia of Somnus, van bescheiden proporties. De uitvoerige schilderingen zijn doel in haarzelf; zij oefenen een groote aantrekkingskracht uit op Ovidius, daar hij in deze figuren al zijn vindingrijkheid kan botvieren. Talloos en vernuftig zijn de details en attributen, van een groote plastische kracht vaak, en steeds afgestemd op het zakelijke, waarvan deze goden de verpersoonlijking zijn. Naast uitvoerige, doorloopende beschrijvingen, worden in andere gevallen de verschillende trekjes der personifieering door de verhalen verweven en verspreid. Boreas bijv. wordt door zijn grauwe vleugels, door zijn pulverea palla, en vooral door de domestica ira geteekend, die uit zijn bulderende uitbarsting spreekt („Boreas"). Ook van den berggod Tmolus worden verschillende details gegeven („Midas"). Een korte ekphrasis wordt aan Notus gewijd (,Diluvium”). 
Doch niet enkel in nieuwe, poëtische figuren wordt het zakelijke element met tal van plastische details geschilderd, doch ook in goden met een rijk mythologisch verleden. Naast de ekphrasis van een Invidia staat de ekphrasis van een Sol, even uitvoerig en even rijk aan zinvolle details, waarin de schittering en de astronomische beteekenis van het zonnelichaam verbeeld wordt ; Ovidius schildert niet Helios, doch een figuratie van de zon. $\mathrm{Nu}$ is in de uitbeelding van Sol geen groot contrast tusschen mythologie en poëtische personificatie. Sterker zien wij dat contrast bij Somnus, die in niets meer gelijkt op den Homerischen Hypnos, doch Slaap in persoon is. De snelle Iris vertegenwoordigt den regenboog, zooals uit haar werkzaamheden blijkt (,Diluvium") en haar duizendkleurig kleed plas. tisch aanduidt („Ceyx et Alcyone"). Het sterkste voorbeeld is echter de Ceres uit „Erysichthon", die niet meer de angstige moeder is uit den „Raptus Proserpinae", doch geconcipieerd als het volkomen tegendeel der nieuw geschapen Fames, als het inbegrip der Vruchtbaarheid. Soortgelijke gevallen van demythologiseering en personifieerende herijking vanuit een idee vinden wij nog in andere verhalen. De wagen van Pluto is naar Homerische opvatting evenzeer van goud als de wagen van Helios, wijl een godenwagen; bij Ovidius wordt hij door zwarte paarden getrokken, gemend met zwarte leidsels, details, die ons een aanwijzing geven, hoe wij ons den wagen van den vorst der onderwereld moeten denken, bepaald namelijk door den aard der werkzaamheden van den duisteren bezitter („Raptus Proserpinae"). De weg naar de onderwereld wordt door Ovidius, afwijkend van de traditie, zoo geconcipieerd en gestoffeerd, dat in alles het begrip dood en doodsch tot zijn recht komt („Ino"). Zoo worden ook in de materialen, warin de archieven der Parcen opgetrokken zijn ("Caesaris apotheosis"), de ijzeren beschikkingen des lots uitgebeeld.

De demythologiseering is echter niet volkomen; de dichter gebruikt daarnaast ook mythologische details. Genoemde Sol is ook Phoebus en vader van Phaethon; Iris blijft de bode van Juno; Ceres behoudt de beschikking over den slangenwagen van den Eleusinischen cultus.

Deze godheden nu zijn niet enkel verpersoonlijking van de zaak, die zij verbeelden, doch zijn deze zaken ook in werkelijkheid en geheel en al, niet slechts in een bepaald opzicht. De aanwezigheid van Fames of van Somnus verwekt per se honger of slaap. Ceres is de vruchtbaarheid, en kan dus per definitionem niet zijn, waar Fames is. Sol is de zon, zoodat hij bij zekere gelegenheden verduistert. Iris is de regenboog, als hoedanig zij, de wolken voedende, water opzuigt van de aarde. Atmospherische verschijnselen getuigen van de identiteit van Lucifer en Aurora met morgenster en dageraad ("Ceyx et Alcyone", "Aurora"). Tellus is de aarde, waarin zich de bronnen hebben teruggetrokken; haar schokken zijn aardbevingen („Phaethon”). Tmolus heeft heusche boomen op zijn hoofd, mons (,Midas"). Boreas is ventus (,Boreas"). Alpheus en Achelous zijn onmiskenbaar rivieren („Arethusa”, „Echinades”). Het zakelijk moment in deze goden wordt tot het uiterste doorgevoerd.

Doch daarnaast is ook het persoonlijke moment in deze eponyme godheden sterk ontwikkeld, ontwikkeld tot het al te menschelijke toe. In de beschrijvingen van sterk allegorische figuren als Invidia of Somnus treffen ons allerlei biotische 
details. Invidia zucht van afgunst bij het zien der schoone Pallas; nauwelijks kan zij haar tranen bedwingen, als zij geen ellende kan ontdekken. Somnus, slaapdronken, knikkebolt, dat het een aard heeft. Tellus bij den wereldbrand houdt vanwege de zengende hitte de hand voor haar hoofd en schokt van de pijn. Tmolus, om goed te kunnen luisteren, strijkt zijn boomen achter de ooren. Sol moet zich op zijn hoogen post vermannen, om niet, duizelig geworden, een halsbrekenden val te maken, en dezelfde figuur, die troont tusschen Jaargetijden en Tijdsmaten, slaat na den dood van zoonlief aan het mokken en is slechts met dreigementen tot de orde te roepen. In dit verband kan het weinig verwondering baren, dat natuurwezens als nymphen de zegeningen der beschaving kennen, als rouwkleeding en jury's van gezworenen („Salmacis", „Musae").

De dichter bespaart ons de verwarring niet, die ontstaat door een vermenging van het uiterst-zakelijke en het uiterst-persoonlijke in een en dezelfde figuur. Wij vallen van de eene inconsistentie in de andere. Wij zien bijv. de aardmoeder tot haar hals uit de aarde te voorschijn komen - zij is dus niet de aarde zelf doch hooren even later, dat zij zich in zichzelf terugtrekt. Zeer sterk voelen wij de inconsistentie tusschen beide momenten, waar natuurverschijnselen worden voorgesteld als reacties en symptomen van typisch menschelijke aandoeningen. Als Boreas de beminde Orithyia rooft, flikkert het bliksemvuur, dat eigenlijk, zooals de dichter te verstaan geeft, aan collisie der wolken te wijten is, nog feller vanwege het minnevier in 's goden boezem. Tellus siddert van de pijn : aardbevingen. Sol, door Leucothoë's schoonheid betooverd, verwijlt langer aan den hemel om haar te kunnen zien, en de dagen lengen; soms bezwijmt hij van haar schoonheid : zonsverduistering. In zonsverduistering ook openbaart zich zijn smart om Phaethon's dood. Ook de oudersmart van Lucifer en Aurora openbaart zich in atmospherische verschijnselen. De woede van Achelous openbaart zich in het zwellen van den Achelous. Aan den anderen kant auget Inachus fletibus aquas; weenende Rivieren zwellen door hun eigen tranen ("Echinades”). In een paroxysme van vreemde esprit voert Ovidius dit spel met de dupliciteit der eponyme godheden ad absurdum in de dubbele beteekenis der namen. De namen worden in één adem persoonlijk en zakelijk geïnterpreteerd, zoodat de dichter kan spelen met het reflexivum. Rouwend hult Sol zich in wolken, en men is één dag sine sole; in zijn smart is hij het leven en het zonnelicht moede, zichzelf dus (lucemque odit seque ipse diemque). Tellus surmque Rettulit os in se ("Phaethon"). Invidia carpit et carpitur una Suppliciumque suum est. Fames seque viro inspirat. Somnus excussit tandem sibi se. Tmolus neemt plaats monte suo; Tmolus' vultum sua silva secuta est. Lacrimis quoque Flumina dicunt Increvisse suis. Alpheus vertitur in proprias undas. Dat Bacchus $=$ wijn is, is niet ongewoon ; dat wijn $=$ Bacchus is, is niet gewoon ; Ovidius gaat nog een stap verder, en omschrijft Bacchus nog weer als auctor muneris („Midas”), suggereerend, dat onder omstandigheden Bacchus zichzelf drinkt.

Het spel met de dupliciteit der eponyme godheden wordt dus tot in de uiterste consequenties gespeeld, waarbij de laatste mogelijkheid eener poëtische illusie te niet wordt gedaan. Er kan dus van toeval geen sprake zijn. Ovidius speelt niet 
een enkele maal, doch steeds met de dupliciteit der eponyme godheden, en welbewust.

\section{Humor en ironie.}

Tenslotte moeten wij spreken over den humor en de ironie in de godenschildering. Deze zijn, hoe gemakkelyjk ook te proeven, vaak moeilyk in woorden te vangen. Kleingheden zijn vaak beslissend. Het maakt bijvoorbeeld een heel verschil ut, of Juppiter Mercurius vocat als superum rector dan wel conspiratorisch sevocat (,Europa") ; victor wordt Juppiter genoemd, als hy na een erotische worsteling ten hemel vaart: het woord wekt een wereld van associaties („Callisto"). Ovidius' ironie en badinage zijn soepel en vol afwisseling De ronie zijner coquette Muze komt voor in allerlei nuances, soms is zij fijn en ingehouden, soms dartel en utbundig, hier ligt zij als een milde glans over zijn verzen, daar flikkert zij verblindend. De dichter bereikt zijn ironisch effect nu eens door een episch breedvoenge schildering (bujv. van Mercurnus, boven de Atheensche schoonen rondcurkelend, in "Herse"), dan weer door een uterst zakelijke vertelling (bijv. in "Chione"), een andere maal door een kort, insinueerend referaat (,Mars et Venus"), elders door een bijna notarieele opsomming ("Arachne") Tegenover de berekende reticentie en quasi-objectiviteit van Juppiter's worsteling met Callisto staat een even berekende levendigheid in "Europa”. In een breede periode ontwikkelt hy het thema van den strijd tusschen majesteit en liefde ("Europa"), kort en huppelend is de commentaar op Daphne's wensch om maagd te bluven. $Z_{1 j n}$ de ontboezemingen van Juno burlesk-onstumig, daartegenover wordt in korte kommata, smudig aangepast aan de versmaat, het geintrgueer van de hemelkoningin tegenover Semele gesuggereerd De dichter kent het effect der retardatie ("Callısto", „Actaeon"), van rhythme en variatie („Io"). Hij kent de waarde van de apostrophe om aan de ironie kracht bij te zetten ("Admetus", "Leucothoe") $\mathrm{H}_{\mathrm{j}}$ kent de suggestie van de litotes ("Peleus et Thetıs"). Een ander maal vergroot hij de uronie door een verrassend zeugma ("Coronis", "Mars et Venus", „Adonis"). Ook zinspelıngen op andere dichters versmaadt hij net. $\mathrm{H}_{1}$ persifleert de „Io" van Calvus; de formuleenng in „Hyacinthus" herinnert ons aan een ironische passage van Tibullus ; door de opsomming van Vertumnus' manipulaties gluurt ondeugend de elegie van Propertius („Pomona”) Wat bij Vergilius de glone van Diana verhoogt (supereminet omnes), maakt bij Ovidius, die deze woorden citeert, de situatie voor de naakte godin slechts penibeler („Actaeon") Door Vergliaansche wendingen wordt ook de vermakelıkheid van Juno's monologen net weinig verhoogd ("Callisto", „Semele") Zelfs de werken der plastiek zijn Ovidius voor rronsche effecten dienstig: zoo zien wij in "Coronıs" de beteuterde Apollo van het voetstuk van den majestertelyken Cithar. oedus vallen. Deze en dergelyke middelen worden steeds weer door elkaar gebrukt met groote soepelheid. Het zijn de tallooze kleinigheden, die voor de sfeer der verhalen vaak beslissend zijn. De toon maakt de muziek.

Ovidius maakt zich vroolijk om de goden Allen moeten zij het ontgelden, doch in het bijzonder de amoureuze Juppiter en de jaloersche Juno De dichter spaart zijn goden net, noch in hun liefdesverhalen noch elders. $\mathrm{H}_{\text {y }}$ vermydt de 
penibele situaties niet, doch schept ze integendeel graag (,Io") en verwijlt erbij (,Actaeon"). Verhalen als "Io", „Callisto" en "Semele" herinneren bijzonder sterk aan de comedie; doch ook in den episch gestyleerden „Phaethon" ontbreekt de comische noot niet, en achtereenvolgens moeten Nereus, Pluto, Neptunus en de goden al, Juppiter niet uitgezonderd, hun tol aan 's dichters luim betalen. De dichter heeft geen greintje ontzag voor de hemelingen; dit wordt wel bewezen door de wijze, waarop hij speelt met de bliksemschichten van den oppergod (,Semele") of met de orakels van Apollo („Daphne"). Wat de goden tot een bron van genoegen maakt, is het contrast tusschen hun eigenlijke goddelijke verhevenheid en hun feitelijk kleinmenschelijk gedrag. Ampele voorbeelden kan men hierboven vinden in het overzicht van de vermenschelijking, moderniseering en het spel met de dupliciteit der eponyme godheden. Speciaal onder vermenschelijking zijn allerlei motieven en uitspraken van Ovidius naar voren gehaald, die bewezen, dat Ovidius de goden niet enkel vermenschelijkt, doch dit ook welbewust doet. Al deze details kunnen ook dienst doen, om aan te toonen, dat Ovidius de goden ironiseert en een loopje met hen neemt. Hij glimlacht om hun lichtgeraakte ijdelheid, hun onverbeterlijke begeerlijkheid, hun dienstbaarheid aan Amor, hoe zij hun cultusplaatsen in hun verliefdheid verwaarloozen, hoe zij om hun liefde hun majesteit te grabbel gooien. De dichter suggereert het niet enkel, doch spreekt het ook uit, en dat in een episch werk. Er kan dus geen twijfel over bestaan, dat de dichter het ironisch effect zoekt. Wij dichten hem geen ironische bedoelingen toe, hij zoekt de ironie zelf.

Vermenschelijking, moderniseering, het spel met de dupliciteit der eponyme godheden en de ironie, kenmerkend voor de alexandrijnsche godenschildering, vinden wij dus ook bij Ovidius. Ovidius brengt deze alexandrijnsche principes niet toevallig in toepassing, doch welbewust. Ovidius' godenschildering in de Metamorphosen (om deze studie te beperken, bepaalden wij ons tot de Metamorphosen) is alexandrijnsch.

\section{Verhouding tot zijn voorgangers.}

Tenslotte willen wij trachten de vraag te beantwoorden, hoe Ovidius zich in zijn alexandrinisme verhoudt tot zijn voorgangers, of hij zich er toe beperkt hen in hun principes na te volgen dan wel hun principes overneemt door hun middelen te copieeren. In eenzelfde verhaal kan namelijk nu eens dit, dan weer dat principe het meest op den voorgrond treden, en verder kan hetzelfde principe in hetzelfde verhaal op een andere wijze, met andere middelen in practijk gebracht worden. Ook kan, met name bij de moderniseering, het copieeren der middelen van voorgangers in feite leiden tot het schenden van het principe, dat er aan ten grondslag ligt, zooals in de inleiding reeds is uiteengezet. Moderniseering beteekende voor een dichter uit Alexandrië alexandriniseering, voor een dichter uit Rome romaniseering; het copieeren der alexandrijnsche middelen zou dus in bepaalde gevallen kunnen neerkomen op het bestendigen van verouderde of uitheemsche toestanden. Onze samenvatting zal uiterst summier zijn en hoogst onvolledig. Dit moet geweten worden aan de schaarschte van ons vergelijkings- 
materiaal, dat, op zich reeds beperkt, nog meer beperkt is, doordat wij ons slechts tot de godenschildering der Metamorphosen bepaalden. Bij verreweg de meeste verhalen kennen wij Ovidius' zegsman niet. In talrijke gevallen weten wij zelfs niet, of Ovidius zijn stof ontleende aan een poëtische bron dan wel aan een mythologisch compendium. Op welk gedicht van welken dichter of op welk materiaal gaan bijv. de verhalen terug van het Diluvium, van Daphne, Syrinx, Callisto, Herse, Coronis, Europa, Actaeon, Semele, Ino, Arachne, Niobe, Raptus Proserpinae, Arethusa, Boreas, Calydonius aper, Achelous et Hercules, Hyacinthus, Adonis, Glaucus? De resultaten der bronnenstudie zijn hoogst problematisch en in het gunstigst geval vaag. Toch kunnen wij zelfs uit dit materiaal wel enkele, weliswaar algemeene, doch niet onbelangrijke, gegevens putten voor de vraag, welker beantwoording ons thans bezig houdt, terwijl wij voorts in enkele andere gevallen althans zooveel weten, dat een betrouwbare algemeene conclusie kan getrokken worden. De bijzondere omstandigheden der Metamorphosen brachten mede, dat sommige verhalen, als die van Arethusa, van Achelous et Hercules, en van Glaucus door de hoofdpersonen zelf verteld werden. Deze inkleeding komt, zoo mogen wij gerust aannemen, op rekening van Ovidius zelf, en niet van zijn eventueel poëtische bron. Nu heeft Ovidius de mogelijkheden, die het autobiographisch karakter der vertelling voor de vermenschelijking en ironie bood, ten volle en met groot succes uitgebuit; het getuigt van zijn zelfstandigheid en eigen kunnen. Ook mogen wij van de programmatische episodes in het eerste boek - de schildering van den Olympus, van het conflict tusschen Apollo en Amor, en van de schermutseling tusschen Juno en Juppiter - met eenige zekerheid aannemen, dat zij door Ovidius in het verband, warin zij voorkomen, verzonnen en uitgewerkt zijn en wel niet op zijn eventueele poëtische bronnen van „Diluvium”, „Daphne” en „Io" teruggaan. Nu zijn ook deze scenes zeer geslaagde specimina van alexandrinisme en ook zij getuigen van 's dichters vermogen en zelfstandigheid. Het fijne der zaak onttrekt zich evenwel aan onze waarneming. Wel kunnen wij met zekerheid zeggen, dat alle gevallen van moderniseering, wijl romaniseering, tenminste een zelfstandige bewerking van een alexandrijnsch voorbeeld door Ovidius veronderstellen. En deze gevallen zijn even talrijk als gedurfd en geslaagd. Voorzoover deze verhalen op alexandrijnsche dichters teruggaan, bewijst de moderniseering tenminste, dat Ovidius meer is dan een copieerder der middelen zijner voorgangers. Voorzoover de dichter uit een mythologisch compendium putte, geldt dit natuurlijk a fortiori. Wat de verhalen betreft, waarvan wij Ovidius' bron niet kennen, willen wij met deze algemeene gegevens volstaan. Alvorens echter die gevallen te bespreken, waar wij iets weten van zijn alexandrijnsch voorbeeld, willen wij eerst erop wijzen, dat Ovidius zich niet bepaalt tot stof, die reeds door alexandrijnsche dichters bewerkt was. Ovidius zelf bewerkte het eerst poëtisch of verzon een reeks van verhalen en episoden, vooral uit de Romeinsche afdeeling der mythologie en geschiedenis: de Turbida Seditio waarschijnlijk, de verhalen van de Sibylle en van Pomona, de apotheoses van Aeneas, Hersilia en Caesar. Ook hier, ofschoon Ovidius onmogelijk alexandrijnsche voorbeelden copieerde, zijn de alexandrijnsche principes gedecideerd en op gelukkige wijze toegepast, en de 
uitwerking ervan, en stellig de verwerking der motieven, komt natuurlijk op Ovidius' crediet. Ook schoeit Ovidius zelfstandig, zonder alexandrijnsch intermediair, in verschillende verhalen de versie van een niet-alexandrijnsche voorganger op moderne leest. Dit is het geval in de schildering der onderwereld en van de interventie van Venus bij Neptunus in "Ino", van het gesprek van Venus en Juppiter in „Caesaris apotheosis", waar Ovidius eigener beweging een contrast zoekt te bereiken met episodes uit de Aeneis. Ook in het relaas van den brand van Aeneas' schepen geeft onze dichter een andere, van modernen geest doortrokken versie van een episode van Vergilius. Tenslotte moderniseert hij in „Mars et Venus" en in het avontuur van Ulixes met Circe de bekende verhalen van Homerus. Ovidius dreef in al deze gevallen op eigen wieken, en hij bewees, dat hij daartoe volkomen in staat was. Wij mogen daarom ook voor die verhalen, die op een alexandrijnsche bron teruggaan, zelfstandigheid van optreden bij Ovidius verwachten. De gevallen, waar wij Ovidius' alexandrijnsch voorbeeld kennen, bewijzen dit inderdaad. In de verhalenreeks, verweven in het bezoek van Minerva aan de Muzen (,Musae") neemt Ovidius eershalve een heel complex over uit Nicander's Heteroeumena, niet echter zonder wijzigingen in de inkleeding, die door de gewijzigde omstandigheden geboden waren. Nieuw is, wat betreft de godenschildering, de formeele jury der nymphen-gezworenen, een vondst dus van Ovidius zelf. Verder is zijn eigendom de gansche schildering van het bezoek van Minerva en van de conversatie tusschen bezoekster en gastvrouwen, en deze is een der fraaiste gevallen van vermenschelijking. Subtieler staan de zaken in "Lycii coloni", eveneens teruggaande op Nicander. Beide dichters vermenschelijken de godin Latona, doch elk van hen realiseert het principe op andere wijze met andere middelen. Bij Nicander gedraagt de godin zich wel niet ladylike, doch stellig actief, Ovidius echter teekent haar als de klagende, vernederde, passieve verschoppelinge, in denzelfden geest als Callimachus dit had gedaan in zijn Deloshymne. Ovidius copieert Callimachus niet, doch handelt in diens geest, een soort vervolg leverend op diens verhaal. De groote lijnen van het verhaal ontleent hij aan den eenen alexandrijn, de algemeene idee van de schildering der godin aan een anderen alexandrijn, uitwerking en toepassing zijn zijn eigen werk. Op Callimachus' Demeterhymne gaat Ovidius' „Erysichthon" terug. Beide dichters volgen alexandrijnsche principes, doch elk van hen andere ; in de uitbeelding der goddelijke personen, vooral door het spel met de dupliciteit der eponyme godheden gekenmerkt, gaat Ovidius zijn eigen weg. In de schildering tenslotte van het uiterst luxueus-moderne „Convivium Acheloi" zoekt Ovidius een bewust contrast met de beroemde schildering van het gulle, doch rurale maal in Callimachus' Hecale. Callimachus brengt meer het principe der veralledaagsching in toepassing, Ovidius het even alexandrijnsche principe der moderniseering (en verrassing). Wij hebben hier het supreme voorbeeld van Ovidius' zelfstandigheid tegenover den alexandrijnschen grootmeester. Verre van te copieeren, zoekt hij binnen het kader der alexandrijnsche usances een fijn berekende contrastwerking. Ovidius is niet slechts zelfstandig, hij speelt zelfs, niet gezel, doch zelf een meester.

Dit beteekent niet, dat Ovidius zich nimmer, in geen enkel verhaal of onder- 
deel ervan, aansluit bij de inkleeding, die een alexandrijnsch dichter er reeds aan gegeven had. Doch wel mogen wij op grond van het bovenstaande beweren, dat Ovidius, als hij een alexandrijnsche versie overneemt, dit niet doet als bloedarm copieerder, behoorende tot imitatorum servum pecus, doch zich vrijwillig bij zijn voorbeeld aansluit. Over den aard en den omvang, en niet te vergeten de bedoelingen van deze ontleeningen kunnen wij echter, bij de schaarschte onzer gegevens, niet wel oordeelen. Duizend dingen moeten daarbij in rekening gebracht worden; het komt voor een juiste beoordeeling aan op een complex van subtiele factoren. Fen detail, een enkel woord, een nauwelijks te verwoorden suggestie kunnen een belangrijke verandering teweeg brengen; de vorm kan anders zijn dan bij het voorbeeld; het motief kan uit een ander verhaal getransponeerd zijn, of op een eigen wijze voor de ontwikkeling van een verhaal benut. Ook moeten wij niet vergeten, dat Ovidius graag, wat men zou kunnen noemen citeert. Dit viel reeds zijn tijdgenooten op, en Seneca maior gaf bereids de juiste formuleering voor dergelijke ontleeningen: de dichter deed dit, non subripiendi causa, sed palam mutuandi, hoc animo ut agnosci vellet (suas. 3. 7). In een gedeelte althans van "Io" maakt Ovidius van Calvus' gelijknamig epyllion gebruik; hij citeert zijn voorbeeld, tenminste eenmaal, onmiskenbaar. Toch draagt de Calviaansche passage geheel Ovidius' geestesmerk, en proeven wij er een zekere ironie in om diens lacrimeus lyrisme. Zooals hij hier Calvus citeert zonder een copieerder te zijn, zooals hij het elders Vergilius doet (zie onder „Actaeon”) of Propertius („Pomona”) of Callimachus (zie onder „Daphne”) zonder zijn zelfstandigheid en eigen aard te verliezen, zoo zal hij dit stellig ook vaak daar doen, waar ons de gegevens ontbreken om zijn citaat op zijn waarde en zelfstandigheid te kunnen beoordeelen. Zoo mag men met een zekere waarschijnlijkheid aannemen, dat Ovidius in de beschrijving van de liefdessymptomen van Sol in "Leucothoë" motieven heeft ontleend aan een alexandrijnschen dichter over Sol's liefde tot Phaethon's moeder Clymene. Doch het fijne der zaak kunnen wij niet achterhalen; wij kunnen slechts gissingen maken. Hoogstwaarschijnlijk heeft Ovidius deze motieven zelf getransponeerd naar een verhaal, waar zij hem dienstig waren. Waarschijnlijk heeft hij deze motieven aangevuld met eigen vondsten, en, wat belangrijk is, afgerond tot een verzadigd complex. Daarbij komt, dat hij deze motieven offreert in den vorm van een brillante apostrophe van den hoogen lijder, die niet weinig bijdraagt tot het effect der passage. De ironische mogelijkheden der apostrophe kenden stellig ook de alexandrijnsche dichters ; doch had ook de dichter der liefde tot Clymene er van gebruik gemaakt? Wij worden wel in meer dan een opzicht aan alexandrijnsche voorgangers van Ovidius herinnerd, nochtans is de waarschijnlijkheid groot, dat de melange der onderscheidene elementen typisch Ovidiaansch is, zooals dat het geval is met de Calviaansche passage van "Io". In de beschrijving van Apollo's obsequium tegenover Hyacinthus speelt Ovidius met Tibulliaansch-alexandrijnsche motieven; waarom zou hij in andere gevallen niet spelen met alexandrijnsche motieven? Het motief van de verwaarloozing der cultusplaatsen door de goden verliefd is hoogstwaarschijnlijk alexandrijnsch, wellicht even typisch en conventioneel als de typeering der preutsche jageres een staand motief is. Heeft 
Ovidius dit motief in „Hyacinthus" en „Adonis" overgenomen of getransponeerd en toegepast uit andere verhalen? Dat hij het overneemt, geschiedt op denzelfden grond, waarop hij de typeering der preutsche jageres overneemt en herhaalt, omdat het een prettig en genoeglijk motief is, even volmaakt in zijn behaaglijkheid als de gebruikelijke beek lene sonantis aquae (Am. 3. 5.6 ; F. 2. 704 ; F. 6. 340) der gebruikelijke idyllische scenerie: het motief is voortreffelijk, en moet niet steeds door iets nieuws vervangen, doch genoten worden en speels benut. En dat hij ermede kan jongleeren, bewijst "Admetus", waar hij vrijwel zeker een alexandrijnsche passage, misschien van Nicander, voor oogen heeft. In dit verhaal gebruikt hij het motief zeer ingenieus en verre van mechanisch, om namelijk den overgang tot stand te brengen van het eene verhaal naar het andere. In dit spelend verwerken van een bekend motief herinnert "Admetus" aan het "Convivium Acheloi", waar Ovidius eveneens speelt, met Callimacheïsche motieven. Hier wil hij een contrast met zijn alexandrijnschen voorganger, daar sluit hij zich bij hem aan. Het verhaal van Syrinx lijkt wel geheel uit conventioneele alexandrijnsche motieven te zijn samengesteld; desniettemin is het een der gelukkigste voorbeelden van Ovidius' gratie en spelende zelfstandigheid, vooral als men het in zijn verband beschouwt. Dat bepaalde alexandrijnsche motieven Ovidius na aan het hart liggen, blijkt vooral uit het verhaal van Pomona, een eigen verzinsel van Ovidius, waarin hij echter bewust en als het ware hardnekkig zooveel mogelijk slechts bekende motieven uit de luchtige Grieksche godenamours in hun Latijnschen tegenhanger overhevelt. Met ontleeningen te constateeren zonder meer komen wij er niet; de zaken zijn veel subtieler. Wat hetzelfde lijkt, is niet hetzelfde. Op vele motieven, aan alexandrijnsche dichters ontleend, kunnen wij het woord van Ovidius toepassen, dat slaat op de Nereiden : facies non omnibus una, Non diversa tamen, qualem decet esse sororum (2.13/4). De glorie van Ovidius lijdt onder het ontbreken van de producten zijner voorgangers. Hij is, zooals v on Wil a mowitz (H.D. II p. 44) naar aanleiding van "Erysichthon" opmerkt, "kein blosser Nachbeter der Griechen", „sondern ein Stern mit eigenem Lichte".

Wij spraken van de typisch eigen melange van Ovidius. Dit brengt ons tenslotte tot het $\mathrm{ty}$ pisch eigene van Ovidius in zijn alexandrinisme. De studie der Ovidiaansche godenschildering in de Metamorphosen eindigt aldus, waar zij begon, billijkerwijs : bij het persoonlijk naturel des dichters. Indien wij dit onderwerp adequaat willen behandelen, moeten tal van factoren in het spel betrokken worden. Wij kunnen hier slechts wijzen op enkele decisieve momenten. Laten wij daarbij beginnen met wat naar de formuleering een negativum betee' kent voor Ovidius' alexandrinisme, doch in feite een positivum is voor zijn poëzie. Het betreft de geleerdheid, die als een bloedzuiger kleeft aan de alexandrijnsche poëzie. Wij kunnen niet zeggen, dat Ovidius niet een groote eruditie aan den dag legt, doch van geleerdheid kan geen sprake zijn; waar hij een aanval van geleerdheid heeft, is deze geleerdheid een franje, hij pronkt ermede, omdat het nu eenmaal usance is, bij zijn richting vooral, om ermede te pronken. Het morganatisch huwelijk tusschen geleerdheid en poëzie, waarvoor de alexandrijnsche dichters warm liepen, tot schade van beide partijen, is door Ovidius ontbonden: 
de geleerdheid vond onderdak bij zijn vriend Hyginus, Ovidius wierp zich in de armen der poëzie. Glossen en dergelijke hebben nog slechts waarde als pikante noten, vitia, die voor de coquette Muze een causa decoris zijn (Am. 3.1.10; vergelijk : aiebat (Ovidius) interim decentiorem faciem esse in qua aliquis naevos fuisset, Seneca maior contr. 2. 2. 10). Nicander, zoo zagen wij in "Iphis" streeft naar de aetiologische, Ovidius naar de actueele noot, en werpt de geleerdheid getroost overboord. Hetzelfde zagen wij in "Lycii coloni”. Een nieuw ontdekt verhaal is voor Nicander een aanleiding tot aetiologische bijdragen, voor Ovidius is het een dulcis novitas (dulcique animos novitate tenebo, 4.284); de poëzie prevaleert, in haar souvereine rechten hersteld. Wat Ovidius verhinderde aan de geleerde manie zijner kunstrichting ten offer te vallen, is de dives vena van zijn dichterschap, die algemeen in hem geroemd wordt. Hieraan moet de snelheid en volheid zijner productie worden toegeschreven. E. Rohde (p. 124 vv.) wijst erop, dat Ovidius zich door zijn alexandrijnsche voorbeelden niet laat binden, en dat zijn poëzie licht, geestrijk, beweeglijk, vol, weelderig fantasiespel is. „Kaum lässt sich ein stärkerer Gegensatz denken als zwischen der stets lebendigen, wenn auch zuweilen etwas leichtfertig gewandten Arbeit dieses dichterischen Luca fa presto und der mühsam sorgfältigen, schwerflüssigen, nur stockend sich bewegenden Arbeit der hellenistischen Musterpoeten." (p. 126; over dit laatste kan getwist worden). Uit Ovidius' verhalen de alexandrijnsche voorbeelden willen reconstrueeren is als „ein, wunderlicher Weise in die breite und kecke Manier eines Freskogemäldes umgesetztes Miniaturbild auf seine ursprünglichen zierlichen Formen zu reduciren" (p. 127). En ook Boissier (P. A. p. 124), met een verwijzing naar $R$ oh de, constateert, dat "Ovide est allé beaucoup plus loin que ses maîtres. Il mêle à tout une sorte de bonne humeur et de verve boufonne qui n'est pas dans le génie des Alexandrins. En les imitant, il les a profondément modifiés." Ook R osta g n i (p. 377/8) wijst op het weelderige en colossale in Ovidius' scheppingen, hoe hij de versies zijner voorgangers contamineert, herschept en travesteert in zijn nieuwe manier, die gekenmerkt wordt door levendigheid, onbevangenheid en onvergelijkelijke weelderigheid.

Wij zijn niet meer in de broeikassen eener exotische poëzie, door Ovidius' poëzie waait een frissche bries. Hij is de uitbundigheid zelve ook in de godenschildering. Wanneer hij den Olympus moderniseert, geschiedt dit met een overvloed van details, en hij suggereert ons niet enkel Rome, doch noemt het ook bij name: haud timeam dixisse Palatia caeli. Wanneer hij speelt met de dupliciteit der eponyme godheden, gaat hij tot aan de uiterste grens : excussit sibi se etc. Speelt hij met de begeerlijkheid of de kleinzeerigheid der goden, dan doet hij het ook in alle dartelheid : adspiceres utinam, Saturnia, mitior esses, zoo apostropheert hij de naijverige Juno ("Callisto"), die om haar wraak tot in de hel afdaalt (sustinet ire illuc caelesti sede relicta, "Ino"). Wij worden verschillende malen sterk aan de comedie herinnerd ("Io", "Callisto", „Europa”, „Semele"). Hij persifleert Calvus' Io, de Junomonologen van Vergilius (,Callisto", "Semele") en den hoeder der fata (,Turbida seditio"). Het typisch eigene van Ovidius is zijn vaart en verve en volheid, de uitbundigheid en openhartigheid van zijn dartelheid: lascivus in herois quoque Ovidius (Quintil. 10.1. 88). Hij laat 
zijn genie den vrijen teugel en gaat op in het spel, ingenio maximus, arte valens. Daarom ook is hij niet enkel de bekroner van het alexandrinisme te Rome, doch van het alexandrinisme tout court.

De slotconclusie is dus deze: Ovidius brengt in de godenschildering der Metamorphosen, krachtens zijn eigen aanleg, doch tevens welbewust en over de geheele lijn (de uitzonderingen bevestigen den regel), de alexandrijnsche principes in toepassing van vermenschelijking, moderniseering, het spel met de dupliciteit der eponyme godheden, dit alles doordrenkt van humor en ironie. Hij is daarbij geen imitator, doch realiseert deze principes op eigen vrije wijze, zoowel in verhalen, die op alexandrijnsche dichters teruggaan als in die, welke hij zelf het eerst poëtisch bewerkte of verzon of ook ontleende aan niet-alexandrijnsche dichters. Wat hem speciaal eigen is, is de uitbundige volheid der poésie pure.

Tenslotte merken wij nog op, dat Ovidius' alexandrinisme zich niet bepaalt tot de godenschildering alleen noch tot de Metamorphosen alleen. Om den omvang van deze studie te beperken, werd slechts een belangrijk onderdeel gekozen uit zijn belangrijkste werk, waaruit de voornaamste desbetreffende verhalen en passages besproken werden. De scheidslijn werd arbitrair getrokken, niet echter zonder een uitwendige rechtvaardiging, omdat door de theorie van $\mathrm{H}$ e in ze over de waardeering der godenschildering in de Metamorphosen onder de litteratuurhistorici oneenigheid was gerezen. 


\section{REGISTER}

(Van de godennamen zijn slechts in bijzondere gevallen trefplaatsen uit de inleiding vermeld.)

Achelous : zie riviergoden.

Actaeon $=$ Ovidius ? : 71 . actualiteit in de Met. : 141.175 v. adulterium : 58.75.

Aeëtes : 21 v.

Aesculapius : $159 \mathrm{vv}$.

alexandrinisme :

godenschildering : 23 vv. 167 vv. rationalisme : 137.146 .157$.

geleerdheid : 23 v. $186 \mathrm{v}$.

Catullus en a. : 22. 32.

Vergilius en a. : 19. 24. 32. 97 v.

Ovidius en a. : 18 vv. 167 vv. 182 vv. allegorie : zie personificatie.

von Allmen : 26. 31.

Aly : 24.

Amor : 40 v. 94.96 vv. 124.172.

Amphis : 53.

Anthologia Palatina : 27.

Apollo: 40 vv. 57 vv. 60.102 v. 121 v. 124. 126 vv. 132 v. 137 v.

Palatinus : 50

Apollonius Rhodius : 21.26 vv. $31.96 \mathrm{vv}$. $128 \mathrm{v}$.

apostrophe: 57. 60.76 vv. 102.

Arachne vertegenwoordigt moderne kunst: 104.

Aratus : 56.

Arctos aequoris expers : $55 \mathrm{v}$.

Arethusa : $100 \mathrm{v}$.

Ariadne : 23.

ars casu similis : $11 \mathrm{v}$.

Atlas : 17.

augustus : 118.

Aurora : 58. 119.133 vv.

auxiliares : 38.

Bacchus : 14. 126.

Bartholomé : 7. 36. 39. 48. 50. 103 v. 127.
Barwick : 95.

Beck : 7. 42. 124. 128.

beeldende kunsten: 7. 29. 47. $50.59 \mathrm{v}$. 64.67 vv. 92.98 .102 .124 v. 127 v. 130. 137. 149. 157.176.

Bethe : 26. 30. 90. 94.

Bie : 93.

Bion : 82.

Birt : 44.

Boissier : 1 v. 4 v. 43. 45. 52. 104. 117 . 125. 133.187.

Boreas : $110 \mathrm{v}$.

Brandt: 15. 68. 75. 99. 101.

Braune : 47. 50. 68.

burleske : zie parodie en comedie.

Caeruleus = kuarvoxaims? : 39 .

Cahen : 25.

Callimachus: 3. 7. 22 vv. 39.52 .58 v. 63. 67 vv. 95 vv. 106 v. 110 vv. 113 vv. 116. 119.125 .129 .136 .161$. $165 \mathrm{v}$.

Calliope: 93.

Calvus : 44 vv.

Canens : 81. 149.

Castiglioni : 25. 27. 40. 80. $121 \mathrm{v}$.

cataloog: 79.102 vv. 151.

Catullus : 12. 20. 22. 28. 46. 153. 155.

Ceres : 94.99 v. 115.119.

von Christ-Schmid : 23 v. 28. 30.

Circe : 139 vv.

citeeren : 36.139 v. 155.185.

comedie: 8. 43. 51. 53. 67. 72. 152. 182.

compendium mythologicum : 39.183.

cosmogonie : 9. 16.

Couat : 4. 25. 30 v. 69.

Croiset: 3. 23. 28.

cultusplaatsen verwaarloosd: 27. 31. 60 . 122. 124. 173.

Cybele : 145 . 
Declamatie : $21 e$ rhetonek.

Delande : 9.

Diana . 53. 67 vv. 111. 129.

Dietze : 60. 107.

Dietzler : 34. 96.

Ehwald : 5 en passim.

Bitrem : 43.

elegie : 41.53 .57 vv. 61 vv. 69.74 v. 82. 92. 98. 101. 120.138. 153 v. 177 "elegische" stujl : 5. 94. 156. 175.

Elyseische velden : 86.

Ennius : 155 v.

Enk : 8.

eponyme godheden, spel met dupliatest van : 28 vv. 32.178 vv.

Euhemerisme : 23. 146.

Euripides : 18.26 v. 41.

Fabricius : 10.

Fama : 131 v.

Fames : 115.

Faunt etc. : 36. 47. 81.149 v.

familerelaties : 38. 89. 133.148 .156$. 164. $173 \mathrm{v}$.

Galatea : 82137.

gelegenheidsmotiveering: 36.54 .129$. 131. 165.

geloof en mythologie: 10 vv. 23.

geometrisch vers : 43.74.

Gerber : 126.

Gibbings : 104 v.

Gigantomachia : 3. 96.

Glaucus : 136 v. 142.

Grumal : 60. 67 .

Hardie : 26.

Hartman : 153.

Heinze: 5 vv. 27.32 .35 v. 39 vv. 45.52. 54 v. 62.65 v. 76.94 .109 v. 122. 154. 156.159 v. 175 .

Hercules $=$ Augustus : $117 \mathrm{v}$.

Herter: 25 v. 31. 95. 97.

Hesiodus : 58 v. 74. 80. 90. 137.

Heumann : 26. 136. 146.

hiaat : 69 .

Higham : 10. 13. 92.

hofpoezie: 156.161. $165 \mathrm{v}$.

Homerus : 2. 4.6 vv. 30.36 .46 .49 .55$. 6975 v. 95 vv. 100.113 .130 vv. $139 \mathrm{vv}$.

Horatius : 12. 87. 112. 117. 126. 143.

Huber : 25 v. 30 v. humor en ironie: 30 v. $181 \mathrm{v}$.

Hyginus : 187.

Indicium : $58 \mathrm{v}$.

indirecte gegevens : 25.34 .183 vv.

1ra deorum : 2. 6. 167 vv.

Ir1s : 39. 85.129 v. 158.

Is1s : $120 \mathrm{v}$.

Iuno: 43 vv. 52 vv. 72 vv. 83 vv. 118 . 129. 147.154 v. 158.171 v. 181.

Saturnia : 84.

Iuppiter : 36 v. 42 vv. 52 v. 65 vv. 72 vv. 94.102 .117 v. 119.121 v. 128.135 v. 146 vv. 155 v. 164 v. 171 v. 181.

Tonans : 36 ; bliksem : 74 ; $=$ Augus. tus? 3. 37.

Jackson : 32.35 .

jury : 93.

Kapp : 113. 119.

Kappelmacher : 7.

Kehmptzow : 134.

Kienzle : 70.

kleedij : 82. 141.

Knaack: 25. 29. 47. 50. 56. 78.

Kock : 53. 67.

Korte : 26. 30.

Kroll : 6 v. 22.32.

Lafaye : 3. 32. 42. 47. 69. 76. 114. 117. 139. $141.153 \mathrm{v}$.

Lamarre: 5 49. 52. 62. 125. 133.

Latona : 105 v. $107 \mathrm{vv}$.

leae i.p.v. leones : 140 .

Legrand: 20. 25. 27. 41.

Leo : 3. 20.

liefdesavonturen : 26 v. 169 vv.

litotes : 128.

Lucianus: 4. 8. 65. 78. 103. 110. 122. 132. 170 .

Lucifer : 51. 129.

Lucretius : 52. 87. 157.

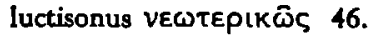

luteus $=$ крокб $\pi \varepsilon \pi \lambda \circ \varsigma ? 134$.

Magie : 137. $140 \mathrm{vv}$.

Mahaffy: 23. 28 v.

Mahly : 12.

Malten : 55 94. 101.

Mars : 75.155 vv.

Martinı : 7. $18 \mathrm{v}$.

Matz : 126.

Mercurius : 46. 61. 65. 128. 170. 
metri causa : 48.125 .135 .156$.

Miller : 51. 126.

Minerva : 63.84 v. 90 vv. 104. moderniseering : $28.175 \mathrm{vv}$.

Mooney : 28.

Morpheus : 12.

Moschus : 27. 64 vv.

Murray : 12.

musaea : 92.

Musaeus : 61 .

Muzen : 90 vv.

Nationale legendes : 4.183.

Neptunus : 38.51 .89 v. 102 v. 106. $132 \mathrm{v}$.

Nereus : 51.

Nicander : 60 v. 81.90 v. 93.95 .107 vv. 120. 129.

Nonnus : 29. 45. 47. 56. 63. 65 vv. 72 v. 77 v. 87. 124. 127. 130 v. 151. 169.

Notus : 39.

nymphen : 81 vv. 116. 142. 149 v.

Oceanus : $55,137$.

Olympus : 35 v. 164 v.

Onderwereld : 85 vv. 100 .

Otis : 8 vv.

Overbeck : 29.132.

Owen : 8. 96.

Parcen : 32 ; archieven der P.: 164 v. parodie etc.: 3. 5. 35. 42.44 vv. 57. 72. 102 v. 154.

penates : 36 .

personificatie: 4. 9. 29. $178 \mathrm{v}$.

Peters : 5. 27. 43. 55.62. 129 v. 151 .

Pfeiffer : 165.

Phaethon : 47 vv. 77 vv.

Philemon en Baucis : 15 v. 113.

Pichon: 3. 62.

Picus : 81. 142. 149.

Pindarus : $58 \mathrm{v}$.

Platner-Ashby : 127.

plebs superum : 35 v.

Pluto: 51. 94.

Pohlenz: 71.

Pokrowskij : 58.

Pomona : 149 vv.

Propertius : 19. 44. 87. 141. 150 vv.

Proserpina : 99.

Pythagoras : 9. 17.

Quintus Smyrnaeus : 134.

Quirinus : 155 vv. : = Augustus : ibd.
Rand : 8. 10. 14. 17. 35. 42. 44. 61. 79. 103.

Reitzenstein : 22, 25. 28, 32.

retardatie, berekende : 53. 100.

rhetoriek: 15. 37. 43.51 v. 85. 92. 106. 109. 117. 124.135 v. 176.

Ribbeck : 2. 6. 17.41 vv. 52.61 v. 69. 83. 101. 113. 154. 161 v. 164. 176.

Ripert : 8. 49 v.

riviergoden : 82. 101. 112. 114. 116.

Rohde A. : 7 vv. 49 v. 146.

Rohde E. : 1.26 v. 136. 187.

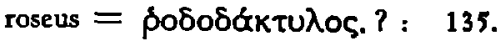

-Rostagni : 187.

Satire : 2. 72. 120.

Schmidt : 7. 15. 90. 112. 159.

Sellar : 2. 81. 129.

Sibylle : 137 v.

Skutsch : 44.

Sol : 48 vv. 76 vv.

Somnus : $130 \mathrm{v}$.

Sophocles : 116.

spondaeën : 59. 69.

Staehelin : 23.

Statius : 22. 48. 87. 96. 136.

Stemplinger : 14.

Stoische theorie: 16. 165.

succincta : 125.

Susemihl : 28.

Taylor : $117 \mathrm{v}$.

Tellus : 51 .

theater : 42.49.

Theocritus : 27. 129.

Thetis : 128 .

Thomann : 26. 30 .

Tibullus: 18.60 .77 .86 v. 121 vv. 124 . 141. 151 v. 162.

Tisiphone : $87 \mathrm{vv}$.

Tmolus : $126 \mathrm{v}$.

Triton : 38.

Tyrrell : 2.

Urania : 93.

Ussani : 8.

Venus : 75. 89. 94.96 vv. 119.124 v. 147 v. 154 v. 161 vv.

verdoemden : 87 .

Vergiluus : 19. 36. 46. 51.56 v. 69. 72. 83 vv. 97 v. 117.119 .130 v. 137 vv. 139 vv. 144 vv. 149. 156. 160 vv. 
verkrachting : 80.153. $169 \mathrm{vv.}$ vermenschelijking : $25 \mathrm{vv} .167 \mathrm{vv}$. vermomming : 27. 61. 152. 169.

Vertumnus : 149 vv.

de la Ville de Mirmont : 3. 21. 26. 28. 31.

Vollgraff : 39.

voorteekenen : $162 \mathrm{v}$.

Vulcanus : 75. 119. 126.

Wagens der goden : 95 v. 100 .

Werner : 110.

Wichers : 155.157. wierook : 38. 111. 168.

von Wilamowitz-Moellendorff : 28. 39. 115 v. 186.

Wissowa : 36. 149. 155. 157.

woordherhaling: 45. 47. 61 .

wrijving in de verhalen: 40.54 .64 .155$. 165.

Zeugma : 59. 125.

Zielinski : 70. 115.

Zingerle : 21.

Zoellner : 22. 


\section{STELLINGEN}

I

Ovidius is vatbaar voor de poëzie van den godsdienst, doch practiseert den godsdienst der poëzie.

II

De schildering van Achelous' luxueus gastmaal (Met. VIII 547 vv.) is door Ovidius bedoeld als een contrast met de bekende schildering van Theseus' bescheiden onthaal in de Hecale van Callimachus.

\section{III}

Dat Nicander's verhaal van de Lycische boeren door Ovidius gekend werd, bewijzen in de versie van laatstgenoemde (Met. VI 317/81) juist de afwijkingen.

\section{IV}

De stelling van $A$. Cordier (Etudes sur le vocabulaire épique dans l'EEnéide", Paris 1939, p. 226) "que Livius Andronicus n'a pas l'idée que le parler épique doit se caractériser par l'abondance du composé" is onaanvaardbaar.

\section{V}

Het motief van ouderlijke genegenheid en instinctmatige verdediging der jongen, kenmerkend voor vele Homerische vergelijkingen, ontbreekt in de vergelijkingen van Apollonius Rhodius en wordt bij dezen vervangen door dat van erotisch sentiment en geslachtsdrift.

\section{VI}

Ovidius' schildering van Hercules' apotheose (Met. IX 239/72) draagt een officieel cachet, omdat deze apotheose een voorafbeelding beteekent van de toekomstige apotheose des keizers.

\section{VII}

Ovidius noemt zijn fictieve geliefde Corinna, omdat Corinna puella beteekent en met puella metrisch equivalent is. 


\section{VIII}

De elegie Amnis harundinibus (Amor. III 6) is een der geslaagdste specimina van Ovidius' kunst.

\section{IX}

De echtheid van Ovid. Amor. III 6 v. $43 / 4$ is aanvechtbaar.

\section{$\mathbf{X}$}

mox etiam Cromnae iuga pallentemque Cytoron

(Val. Flacc., Arg. V 105).

Cytorus wordt pallens genoemd, wijl buxifer.

\section{XI}

te praeceps Euboea tulit, te candida Thisbe miserat, hunc virides non excipietis $f$ Erythrae

(Stat., Th. VIII 768/9).

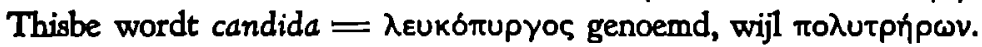

XII

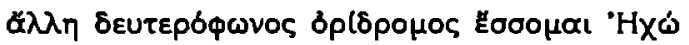

(Nonnus, Dion. II 119).

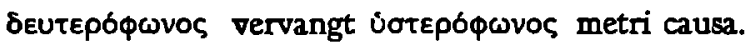

\section{XIII}

Ovid. Met. XIV 9 wordt herbifer door Deipser (Ueber die Bildung und Bedeutung der lateinischen Adjectiva auf fer und ger, Progr. Bromberg 1886, p. 6) onjuist vertaald met "grassreich".

\section{XIV}

nunc ego (opto), quas habuit pinnas Danaeius heros,

terribili densum cum tulit angue caput

(Ovid. Amor. III 6.13/4).

De verklaring, door P. B r andt t.a.p. gegeven (P. O. N. Amorum Libri Tres, Leipzig 1911), als zou terribili angue het monster beduiden, dat Andromeda dreigde te verslinden, moet verworpen worden.

\section{XV}

Af te wijzen is de verklaring van M. J. Brinkgreve (Statii Achilleis brevissima annotatione critica, locis quibusdam parallelis vel comparandis, commentario exegetico instructa, Diss. Utrecht 1913) ad Stat. Ach. I 263 (virgineos si Iuppiter induit artus): „Iuppiter amore Antiopae incensus Dianae habitus sumpsit." 


\section{XVI}

Ten onrechte laat E. K R and (Notes on Ovid. II. Imitation of Ovid in Horace, Transactions and Proceedings of the American Philological Association XXXV, 1904, p. 145) de mogelijkheid open, dat Ovidius Amor. I 15 Propertius niet vermeldt, omdat in den beperkten cataloog van dichters voor dezen geen plaats meer zou zijn.

\section{XVII}

De verwijzing van von Geisa u (Pauly-Wissowas Real-Encyclopädie XX. Halbband, Sp. 2338, s.v. Kastalia) naar Horatius carm. III 4. 61 tot staving zijner stelling „Zum Musenborn, zum Wahrzeichen der Dichtung, haben erst die römischen Dichter .... die K. gemacht" mist allen grond. 


